Supporting Information:

\title{
Multicomponent Pyrazole Synthesis from Alkynes, Nitriles, and Titanium Imido Complexes via Oxidatively Induced N-N Bond Coupling
}

Adam J. Pearce, Robin P. Harkins, Benjamin R. Reiner, Alexander C. Wotal, Rachel J. Dunscomb, and lan A. Tonks*

Contribution from the Department of Chemistry, University of Minnesota - Twin Cities, 207 Pleasant St SE, Minneapolis MN 55455. E-mail: itonks@umn.edu 
$\begin{array}{lr}\text { Synthesis of Compounds } & \text { S-9 }\end{array}$

2-methyl-3-phenyl-3-(phenylimino)-1-(p-tolyl)prop-1-en-1-amine (4a) S-9 Figure S2. ${ }^{13} \mathrm{C}$ NMR Spectrum of $4 \mathrm{a}$ in $\mathrm{CDCl}_{3}$.

2-methyl-3-(phenylimino)-1-(p-tolyl)pent-1-en-1-amine (4b) S-11

Figure S3. ${ }^{1} \mathrm{H}$ NMR spectrum of $\mathbf{4 b}$ in $\mathrm{CDCl}_{3}$.

Figure S4. ${ }^{13} \mathrm{C}$ NMR spectrum of $\mathbf{4 b}$ in $\mathrm{CDCl}_{3}$. S-13

(HNMe $)_{2} \mathrm{TiCl}_{2}\left(\mathrm{ADA}^{\mathrm{Ph}}\right)(5 \mathrm{a}) \quad \mathrm{S}-13$

Figure S5. ${ }^{1} \mathrm{H}$ NMR spectrum of $5 \mathrm{a}$ in $\mathrm{C}_{6} \mathrm{D}_{6}$.

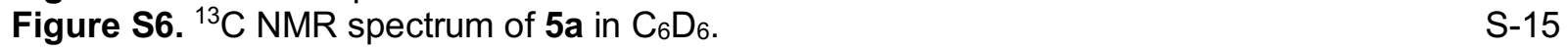

$\mathrm{py}_{2} \mathrm{TiCl}_{2}\left(\mathrm{ADA}^{\mathrm{Ph}}\right)(7 \mathrm{a}) \quad \mathrm{S}-15$

Figure S7. ${ }^{1} \mathrm{H}$ NMR spectrum of $7 \mathrm{a}$ in $\mathrm{C}_{6} \mathrm{D}_{6}$. $\quad \mathrm{S}-16$

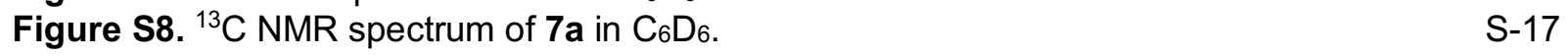

py2 $_{2} \mathrm{TiCl}_{2}\left(\mathrm{ADA}^{\mathrm{Et}}\right)$ (7b) $\quad$ S-17

Figure S9. ${ }^{1} \mathrm{H}$ NMR spectrum of $\mathbf{7 b}$ in $\mathrm{CDCl}_{3}$. $\quad$ S-18

Figure S10. ${ }^{13} \mathrm{C}$ NMR spectrum of $7 \mathbf{b}$ in $\mathrm{CDCl}_{3} . \quad S-19$

1-(2-methyl-3-(p-tolyl)-2H-azirin-2-yl)-N,1-diphenylmethanimine (8a) S-19

Figure S11. ${ }^{1} \mathrm{H}$ NMR spectrum of $8 \mathbf{a}$ in $\mathrm{CDCl}_{3}$.

Figure $\mathrm{S} 12 .{ }^{13} \mathrm{C}$ NMR spectrum of $8 \mathrm{a}$ in $\mathrm{CDCl}_{3}$.

$\mathrm{Cp}_{2} \mathrm{Ti}\left(\mathrm{ADA}^{\mathrm{Ph}}\right)$ (9a) $\quad$ S-21

Figure S13. ${ }^{1} \mathrm{H}$ NMR spectrum of $9 a$ in $\mathrm{C}_{6} \mathrm{D}_{6} . \quad \mathrm{S}-22$

Figure $\mathrm{S} 14 .{ }^{13} \mathrm{C}$ NMR spectrum of $9 a$ in $\mathrm{C}_{6} \mathrm{D}_{6} . \quad \mathrm{S}$-23

Reaction of $\mathrm{Cp}_{2} \mathrm{Ti}\left(\mathrm{ADA}^{\mathrm{Ph}}\right.$ ) (9a) with $\mathrm{PhICl}_{2}$ (synthesis of 10a) S-23

Figure S15. Stacked ${ }^{1} \mathrm{H}$ NMR spectra characterizing the oxidation of $9 \mathrm{a}$ with $\mathrm{PhICl}_{2}$ to $10 \mathrm{a}$. Top (teal trace): ${ }^{1} \mathrm{H}$ NMR of 9a. Bottom (red trace): ${ }^{1} \mathrm{H}$ NMR spectrum of oxidation of $9 \mathrm{a}$ with $\mathrm{PhICl}_{2}$ to

10a. $\quad$ S-24

4,5-diethyl-N-phenyl-3-(p-tolyl)pyrazole (1) S-24

Figure S16. ${ }^{1} \mathrm{H}$ NMR spectrum of 1 in $\mathrm{CDCl}_{3} . \quad$ S-25

Figure S17. ${ }^{13} \mathrm{C}$ NMR spectrum of 1 in $\mathrm{CDCl}_{3}$. S-26

Diazatitanacyclohexadiene oxidations with TEMPO (Table 1, Entry 1) S-26

4-methyl-1,5-diphenyl-3-(p-tolyl)-1H-pyrazole (1a) S-26

Figure S18. ${ }^{1} \mathrm{H}$ NMR spectrum of $1 \mathrm{a}$ in $\mathrm{C}_{6} \mathrm{D}_{6} . \quad \mathrm{S}-27$

Figure S19. ${ }^{1} \mathrm{H}$ NMR spectrum of $1 \mathrm{a}$ in $\mathrm{CDCl}_{3}$.

Figure S20. ${ }^{13} \mathrm{C}$ NMR spectrum of $\mathbf{1 a}$ in $\mathrm{CDCl}_{3} . \quad$ S-29

TEMPO oxidation of 7a (in situ, 2 equiv) S-29

Figure S21. Stacked ${ }^{1} \mathrm{H}$ NMR spectra of in situ oxidation of $7 \mathrm{a}$ with TEMPO. Bottom (red trace): $\mathrm{t}$ $=0$ immediately after the mixing of $7 a$ with TEMPO in $\mathrm{C}_{6} \mathrm{D}_{6}$. Middle (green trace): $\mathrm{t}=1 \mathrm{~h}$ at $50{ }^{\circ} \mathrm{C}$, 
showing the majority conversion of $7 \mathrm{a}$ to $1 \mathrm{a}$. Top (blue trace): $\mathrm{t}=2 \mathrm{~h}$ at $50{ }^{\circ} \mathrm{C}$, showing $>95 \%$ conversion to $\mathbf{1 a}$.

TEMPO oxidation of 7 a (in situ, 1 equiv) (Table 1, entry 2 )

Figure S22. ${ }^{1} \mathrm{H}$ NMR spectrum $(\mathrm{t}=2 \mathrm{~h})$ showing the in situ oxidation of $7 \mathrm{a}$ with 1 equiv TEMPO. S31

\section{Hypervalent lodine Oxidations}

$\mathrm{PhICl}_{2}$ oxidation (Table 1, Entry 3)

Figure S23. Stacked ${ }^{1} \mathrm{H}$ NMR spectra characterizing the oxidation of 7 a with $\mathrm{PhICl}_{2}$ in $\mathrm{C}_{6} \mathrm{D}_{6}$. Bottom (red trace): Clean spectrum of $7 \mathrm{a}$ in $\mathrm{C}_{6} \mathrm{D}_{6}$ (for comparison). Middle (green trace): $\mathrm{t}=20$ min. after mixing $7 \mathrm{a}$ with $\mathrm{PhICl}_{2}$. Top (blue trace): $\mathrm{t}=3 \mathrm{~h}$.

Figure S24. $\mathrm{t}=3 \mathrm{~h}{ }^{1} \mathrm{H}$ NMR spectrum of the $\mathrm{PhICl}_{2}$ oxidation of $7 \mathrm{a}$ in $\mathrm{C}_{6} \mathrm{D}_{6}$.

Phl(TFA)2 oxidation (Table 1, Entry 4)

Figure S25. Stacked ${ }^{1} \mathrm{H}$ NMR spectra characterizing the oxidation of 7 a with $\mathrm{Phl}(T F A)_{2}$ in $\mathrm{C}_{6} \mathrm{D}_{6}$. Bottom (red trace): Clean spectrum of $7 \mathrm{a}$ in $\mathrm{C}_{6} \mathrm{D}_{6}$ (for comparison). Middle (green trace): $t=20$ min. after mixing 7a with Phl(TFA)2. Top (blue trace): $t=3 \mathrm{~h}$.

$\mathrm{Phl}(\mathrm{OAc})_{2}$ oxidation (Table 1, Entry 5)

Figure S27. Stacked ${ }^{1} \mathrm{H}$ NMR spectra characterizing the oxidation of $7 \mathrm{a}$ with $\mathrm{Phl}(\mathrm{OAc})_{2}$ in $\mathrm{C}_{6} \mathrm{D}_{6}$. Bottom (red trace): Clean spectrum of $7 \mathrm{a}$ in $\mathrm{C}_{6} \mathrm{D}_{6}$ (for comparison). Middle (green trace): $\mathrm{t}=20$ min. after mixing 7a with $\mathrm{Phl}(\mathrm{OAc})_{2}$. Top (blue trace): $\mathrm{t}=3 \mathrm{~h}$.

Oxidation of $7 \mathrm{a}$ with $\mathrm{O}_{2}$ (Table 1, Entry 8)

Figure S31. Stacked ${ }^{1} \mathrm{H}$ NMR spectra (alkyl region) characterizing the aerobic oxidation of $7 \mathbf{a}$ over time.

Figure S32. ${ }^{1} \mathrm{H}$ NMR of the $\mathrm{t}=3 \mathrm{~h}$ time point for the aerobic oxidation of $7 \mathrm{a}$.

Multicomponent coupling of $\mathrm{py}_{2} \mathrm{TiCl}_{2}(\mathrm{NPh})$, alkynes and nitriles with TEMPO quench for the synthesis of pyrazoles (isolation conditions)

4,5-diethyl-3-(p-methoxyphenyl)-1-phenyl-1H-pyrazole (1c) S-43

Figure S35. ${ }^{1} \mathrm{H}$ NMR spectrum of $1 \mathrm{c}$ in $\mathrm{CDCl}_{3}$. 
Figure S37. ${ }^{1} \mathrm{H}$ NMR spectrum of $1 \mathrm{~d}$ in $\mathrm{CDCl}_{3}$.

Figure S38. ${ }^{13} \mathrm{C}$ NMR spectrum of $1 \mathrm{~d}$ in $\mathrm{CDCl}_{3}$, with insets showing a zoomed-in view of ${ }^{13} \mathrm{C}-{ }^{19} \mathrm{~F}$ coupling for quartet at $129.40 \mathrm{ppm}(32.3 \mathrm{~Hz})$, and the other showing a zoomed in view of ${ }^{13} \mathrm{C}-{ }^{19} \mathrm{~F}$ coupling for quartets at $125.45 \mathrm{ppm}(3.9 \mathrm{~Hz})$ and $124.50 \mathrm{ppm}(272.5 \mathrm{~Hz})$. Quartet centered at $124.50 \mathrm{ppm}$ most upfield signal not visible.

Figure S39. ${ }^{19} \mathrm{~F}$ NMR spectrum of $1 \mathbf{d}$ in $\mathrm{CDCl}_{3}$, with trifluoroacetic acid reference capillary (set to 76.550ppm).

4,5-diethyl-3-isopropyl-1-phenyl-1H-pyrazole (1e)

Figure S40. ${ }^{1} \mathrm{H}$ NMR spectrum of $1 \mathrm{e}$ in $\mathrm{CDCl}_{3}$.

Figure S41. ${ }^{13} \mathrm{C}$ NMR spectrum of $1 \mathrm{e}$ in $\mathrm{CDCl}_{3}$.

S-50

3,5-dimethyl-1,4-diphenyl-1H-pyrazole (1g)

Figure $542 .{ }^{1} \mathrm{H}$ NMR spectrum of $1 \mathrm{~g}$ in $\mathrm{CDCl}_{3}$.

Figure $543 .{ }^{13} \mathrm{C}$ NMR spectrum of $1 \mathrm{~g}$ in $\mathrm{CDCl}_{3}$.

S-52

Figure S44. ${ }^{1} \mathrm{H}-{ }^{15} \mathrm{~N}$ HMBC NMR spectrum of $1 \mathrm{e}$ in $\mathrm{CDCl}_{3}$.

S-53

5-methyl-1,3,4-triphenyl-1 $\mathrm{H}$-pyrazole (1h)

S-53

Figure S45. ${ }^{1} \mathrm{H}$ NMR spectrum of $1 \mathrm{~h}$ in $\mathrm{CDCl}_{3}$.

S-54

Figure S46. ${ }^{13} \mathrm{C}$ NMR spectrum of $1 \mathrm{~h}$ in $\mathrm{CDCl}_{3}$.

S-55

Figure S47. ${ }^{1} \mathrm{H}-{ }^{15} \mathrm{~N} \mathrm{HMBC}$ NMR spectrum of $1 \mathrm{~h}$ in $\mathrm{CDCl}_{3}$.

S-56

4,5-dimethyl-1,3-diphenyl-1H-pyrazole (1i)

Figure S48. ${ }^{1} \mathrm{H}$ NMR spectrum of $1 \mathrm{i}$ in $\mathrm{CDCl}_{3}$.

S-57

Figure S49. ${ }^{13} \mathrm{C}$ NMR spectrum of $1 \mathrm{i}$ in $\mathrm{CDCl}_{3}$.

S-58

1,3,4,5-tetraphenyl-1H-pyrazole (1k)

S-58

Figure S50. ${ }^{1} \mathrm{H}$ NMR spectrum of $1 \mathbf{k}$ in $\mathrm{CDCl}_{3}$, with inset showing a zoomed-in view of the aryl

$(7.60-7.00 \mathrm{ppm})$ region for clarity.

Figure $\mathrm{S} 51 .{ }^{13} \mathrm{C}$ NMR spectrum of $1 \mathrm{k}$ in $\mathrm{CDCl}_{3}$, with inset showing a zoomed-in view of the aryl

$(155-115 \mathrm{ppm})$ region for clarity.

Multicomponent coupling of $\mathrm{py}_{2} \mathrm{TiCl}_{2}(\mathrm{NPh})$, alkynes and nitriles with TEMPO quench for the synthesis of pyrazoles: in situ

Table 2, Entry 1

Figure S52. $\mathrm{t}=1 \mathrm{~h}{ }^{1} \mathrm{H}$ NMR spectrum of multicomponent coupling of 3-hexyne (3 equiv.), $p$ -

tolunitrile (3 equiv.) and $\left[\mathrm{py}_{2} \mathrm{TiCl}_{2}(\mathrm{NPh})\right]_{2}$ in $\mathrm{PhBr}$.

Figure S53. $\mathrm{t}=2 \mathrm{~h}{ }^{1} \mathrm{H}$ NMR spectrum of multicomponent coupling of 3-hexyne (3 equiv.), $p$ tolunitrile (3 equiv.) and $\left[\mathrm{py}_{2} \mathrm{TiCl}_{2}(\mathrm{NPh})\right]_{2}$ in $\mathrm{PhBr}$ after TEMPO addition.

Figure S54. Stacked ${ }^{1} \mathrm{H}$ NMR spectra characterizing the multicomponent coupling of 3-hexyne (3 equiv.), $p$-tolunitrile (3 equiv.) and $\left[\mathrm{py}_{2} \mathrm{TiCl}_{2}(\mathrm{NPh})\right]_{2}$ in $\mathrm{PhBr}$. Bottom (red trace): $\mathrm{t}=0$. Middle (green trace): $\mathrm{t}=1 \mathrm{~h}$ at $115^{\circ} \mathrm{C}$ generating metallacycle analogous to 7 , prior to TEMPO addition. Top (blue trace): $\mathrm{t}=2 \mathrm{~h}$ after TEMPO addition to give pyrazole 1 .

Table 2, Entry 2

Figure S55. $\mathrm{t}=1 \mathrm{~h}{ }^{1} \mathrm{H}$ NMR spectrum of multicomponent coupling of 3-hexyne (3 equiv.), benzonitrile (3 equiv.) and $\left[\mathrm{py}_{2} \mathrm{TiCl}_{2}(\mathrm{NPh})\right]_{2}$ in $\mathrm{PhBr}$.

Figure S56. $t=2 \mathrm{~h}{ }^{1} \mathrm{H}$ NMR spectrum of multicomponent coupling of 3-hexyne (3 equiv.), benzonitrile (3 equiv.) and [py $\left.2 \mathrm{TiCl}_{2}(\mathrm{NPh})\right]_{2}$ in $\mathrm{PhBr}$ after TEMPO addition. 
(green trace): $\mathrm{t}=1 \mathrm{~h}$ at $115{ }^{\circ} \mathrm{C}$ generating metallacycle analogous to 7 , prior to TEMPO addition. Top (blue trace): $\mathrm{t}=2 \mathrm{~h}$ after TEMPO addition to give pyrazole $\mathbf{1 b}$.

Table 2, Entry 3

S-66

Figure S58. $\mathrm{t}=4 \mathrm{~h}{ }^{1} \mathrm{H}$ NMR spectrum of multicomponent coupling of 3-hexyne, benzonitrile and $\left[\mathrm{py}_{2} \mathrm{TiCl}_{2}(\mathrm{NPh})\right]_{2}$ in $\mathrm{PhBr}$.

Figure S59. $t=2 \mathrm{~h}{ }^{1} \mathrm{H}$ NMR spectrum of multicomponent coupling of 3-hexyne, benzonitrile and $\left[\mathrm{py}_{2} \mathrm{TiCl}_{2}(\mathrm{NPh})\right]_{2}$ in $\mathrm{PhBr}$ after TEMPO addition.

Figure S60. Stacked ${ }^{1} \mathrm{H}$ NMR spectra characterizing the multicomponent coupling of 3-hexyne, benzonitrile and $\left[\mathrm{py}_{2} \mathrm{TiCl}_{2}(\mathrm{NPh})\right]_{2}$ in $\mathrm{PhBr}$. Bottom (red trace): $\mathrm{t}=0$. Middle (green trace): $\mathrm{t}=4 \mathrm{~h}$ at $115{ }^{\circ} \mathrm{C}$ generating metallacycle analogous to 7, prior to TEMPO addition. Top (blue trace): $\mathrm{t}=2 \mathrm{~h}$ after TEMPO addition to give pyrazole $\mathbf{1 b}$.

Table 2, Entry 4

Figure S61. $t=4 \mathrm{~h}{ }^{1} \mathrm{H}$ NMR spectrum of multicomponent coupling of 3-hexyne, 4methoxybenzonitrile and $\left[\mathrm{py}_{2} \mathrm{TiCl}_{2}(\mathrm{NPh})\right]_{2}$ in $\mathrm{PhBr}$.

Figure S62. $t=4 \mathrm{~h}{ }^{1} \mathrm{H}$ NMR spectrum of multicomponent coupling of 3-hexyne, 4methoxybenzonitrile and $\left[\mathrm{py}_{2} \mathrm{TiCl}_{2}(\mathrm{NPh})\right]_{2}$ in $\mathrm{PhBr}$ after TEMPO addition.

S-71

Figure S63. Stacked ${ }^{1} \mathrm{H}$ NMR spectra characterizing the multicomponent coupling of 3-hexyne, 4methoxybenzonitrile and $\left[\mathrm{py}_{2} \mathrm{TiCl}_{2}(\mathrm{NPh})\right]_{2}$ in $\mathrm{PhBr}$. Bottom (red trace): $\mathrm{t}=0$. Middle (green trace): $\mathrm{t}$ $=4 \mathrm{~h}$ at $115^{\circ} \mathrm{C}$ generating metallacycle analogous to 7, prior to TEMPO addition. Top (blue trace): $\mathrm{t}=2 \mathrm{~h}$ after TEMPO addition to give pyrazole $1 \mathrm{c}$.

\section{Table 2, Entry 5}

Figure S64. $\mathrm{t}=4 \mathrm{~h}{ }^{1} \mathrm{H}$ NMR spectrum of multicomponent coupling of 3-hexyne, 4(trifluoromethyl)benzonitrile and $\left[\mathrm{py}_{2} \mathrm{TiCl}_{2}(\mathrm{NPh})\right]_{2}$ in $\mathrm{PhBr}$.

Figure S65. $\mathrm{t}=2 \mathrm{~h}{ }^{1} \mathrm{H}$ NMR spectrum of multicomponent coupling of 3-hexyne, 4(trifluoromethyl)benzonitrile and $\left[\mathrm{py}_{2} \mathrm{TiCl}_{2}(\mathrm{NPh})\right]_{2}$ in $\mathrm{PhBr}$ after TEMPO addition.

Figure S66. Stacked ${ }^{1} \mathrm{H}$ NMR spectra characterizing the multicomponent coupling of 3-hexyne, 4trifluoromethylbenzonitrile and $\left[\mathrm{py}_{2} \mathrm{TiCl}_{2}(\mathrm{NPh})\right]_{2}$ in $\mathrm{PhBr}$. Bottom (red trace): $\mathrm{t}=0$. Middle (green trace): $\mathrm{t}=4 \mathrm{~h}$ at $115{ }^{\circ} \mathrm{C}$ generating metallacycle analogous to 7 , prior to TEMPO addition. Top (blue trace): $\mathrm{t}=2 \mathrm{~h}$ after TEMPO addition to give pyrazole $\mathbf{1 d}$.

Table 2, Entry 6

Figure S67. $\mathrm{t}=4 \mathrm{~h}{ }^{1} \mathrm{H}$ NMR spectrum of multicomponent coupling of 3-hexyne, isobutyronitrile and $\left[\mathrm{py}_{2} \mathrm{TiCl}_{2}(\mathrm{NPh})\right]_{2}$ in $\mathrm{PhBr}$.

Figure S68. $t=2 \mathrm{~h}^{1} \mathrm{H}$ NMR spectrum of multicomponent coupling of 3-hexyne, isobutyronitrile and $\left[\mathrm{py}_{2} \mathrm{TiCl}_{2}(\mathrm{NPh})\right]_{2}$ in $\mathrm{PhBr}$ after TEMPO addition.

Figure S69. Stacked ${ }^{1} \mathrm{H}$ NMR spectra characterizing the multicomponent coupling of 3-hexyne, isobutyronitrile and $\left[\mathrm{py}_{2} \mathrm{TiCl}_{2}(\mathrm{NPh})\right]_{2}$ in $\mathrm{PhBr}$. Bottom (red trace): $\mathrm{t}=0$. Middle (green trace): $\mathrm{t}=4 \mathrm{~h}$ at $115^{\circ} \mathrm{C}$ generating metallacycle analogous to 7 , prior to TEMPO addition. Top (blue trace): $\mathrm{t}=2$ $\mathrm{h}$ after TEMPO addition to give pyrazole $1 \mathrm{e}$.

Table 2, Entry 7

Figure S70. $\mathrm{t}=4 \mathrm{~h}{ }^{1} \mathrm{H}$ NMR spectrum of multicomponent coupling of 3-hexyne, acetonitrile and [py2 $\left.\mathrm{TiCl}_{2}(\mathrm{NPh})\right]_{2}$ in $\mathrm{PhBr}$.

Figure S71. $\mathrm{t}=2 \mathrm{~h}{ }^{1} \mathrm{H}$ NMR spectrum of multicomponent coupling of 3-hexyne, acetonitrile and $\left[\mathrm{py}_{2} \mathrm{TiCl}_{2}(\mathrm{NPh})\right]_{2}$ in $\mathrm{PhBr}$ after TEMPO addition.

Figure S72. Stacked ${ }^{1} \mathrm{H}$ NMR spectra characterizing the multicomponent coupling of 3-hexyne, acetonitrile and $\left[\mathrm{py}_{2} \mathrm{TiCl}_{2}(\mathrm{NPh})\right]_{2}$ in $\mathrm{PhBr}$. Bottom (red trace): $\mathrm{t}=0$. Middle (green trace): $\mathrm{t}=4 \mathrm{~h}$ at $115{ }^{\circ} \mathrm{C}$ generating metallacycle analogous to 7, prior to TEMPO addition. Top (blue trace): $\mathrm{t}=2 \mathrm{~h}$ after TEMPO addition to give pyrazole $\mathbf{1 f}$. 
Table 2, Entry 8

Figure S73. $\mathrm{t}=4 \mathrm{~h}{ }^{1} \mathrm{H}$ NMR spectrum of multicomponent coupling of 1-phenyl-1-propyne, acetonitrile and $\left[\mathrm{py}_{2} \mathrm{TiCl}_{2}(\mathrm{NPh})\right]_{2}$ in $\mathrm{PhBr}$.

Figure S74. $\mathrm{t}=2 \mathrm{~h}{ }^{1} \mathrm{H}$ NMR spectrum of multicomponent coupling of 1-phenyl-1-propyne, acetonitrile, and $\left[\mathrm{py}_{2} \mathrm{TiCl}_{2}(\mathrm{NPh})\right]_{2}$ in $\mathrm{PhBr}$ after TEMPO addition.

Figure S75. Stacked ${ }^{1} \mathrm{H}$ NMR spectra characterizing the multicomponent coupling of 1-phenyl-1propyne, acetonitrile and $\left[\mathrm{py}_{2} \mathrm{TiCl}_{2}(\mathrm{NPh})\right]_{2}$ in $\mathrm{PhBr}$. Bottom (red trace): $\mathrm{t}=0$. Middle (green trace): $\mathrm{t}$ $=4 \mathrm{~h}$ at $115{ }^{\circ} \mathrm{C}$ generating metallacycle 7 , prior to TEMPO addition. Top (blue trace): $\mathrm{t}=2 \mathrm{~h}$ after TEMPO addition to give pyrazole $\mathbf{1 g}$.

Table 2, Entry 9

Figure S76. $\mathrm{t}=4 \mathrm{~h}{ }^{1} \mathrm{H}$ NMR spectrum of multicomponent coupling of 1-phenyl-1-propyne, benzonitrile, and $\left[\mathrm{py}_{2} \mathrm{TiCl}_{2}(\mathrm{NPh})\right]_{2}$ in $\mathrm{PhBr}$.

Figure S77. $\mathrm{t}=2 \mathrm{~h}{ }^{1} \mathrm{H}$ NMR spectrum of multicomponent coupling of 1-phenyl-1-propyne, benzonitrile, and $\left[\mathrm{py}_{2} \mathrm{TiCl}_{2}(\mathrm{NPh})\right]_{2}$ in $\mathrm{PhBr}$ after TEMPO addition.

Figure S78. Stacked ${ }^{1} \mathrm{H}$ NMR spectra characterizing the multicomponent coupling of 1-phenyl-1propyne, benzonitrile and $\left[\mathrm{py}_{2} \mathrm{TiCl}_{2}(\mathrm{NPh})\right]_{2}$ in $\mathrm{PhBr}$. Bottom (red trace): $\mathrm{t}=0$. Middle (green trace): $\mathrm{t}=4 \mathrm{~h}$ at $115^{\circ} \mathrm{C}$ generating metallacycle analogous to 7, prior to TEMPO addition. Top (blue trace): $\mathrm{t}=2 \mathrm{~h}$ after TEMPO addition to give pyrazole $1 \mathrm{~h}$.

Table 2, Entry 10

Figure S79. $\mathrm{t}=4 \mathrm{~h}{ }^{1} \mathrm{H}$ NMR spectrum of multicomponent coupling of 2-butyne, benzonitrile and $\left[\mathrm{py}_{2} \mathrm{TiCl}_{2}(\mathrm{NPh})\right]_{2}$ in $\mathrm{PhBr}$.

Figure S80. $t=2 \mathrm{~h}{ }^{1} \mathrm{H}$ NMR spectrum of multicomponent coupling of 2-butyne, benzonitrile and [py $\left.2 \mathrm{TiCl}_{2}(\mathrm{NPh})\right]_{2}$ in $\mathrm{PhBr}$ after TEMPO addition.

Figure S81. Stacked ${ }^{1} \mathrm{H}$ NMR spectra characterizing the multicomponent coupling of 2-butyne, benzonitrile and $\left[\mathrm{py}_{2} \mathrm{TiCl}_{2}(\mathrm{NPh})\right]_{2}$ in $\mathrm{PhBr}$. Bottom (red trace): $\mathrm{t}=0$. Middle (green trace): $\mathrm{t}=4 \mathrm{~h}$ at $115{ }^{\circ} \mathrm{C}$ generating metallacycle analogous to 7, prior to TEMPO addition. Top (blue trace): $\mathrm{t}=2 \mathrm{~h}$ after TEMPO addition to give pyrazole $1 \mathbf{i}$.

Table 2, Entry 11

Figure S82. $\mathrm{t}=4 \mathrm{~h}{ }^{1} \mathrm{H}$ NMR spectrum of multicomponent coupling of bis(4-tbutylphenyl)acetylene, benzonitrile and $\left[\mathrm{py}_{2} \mathrm{TiCl}_{2}(\mathrm{NPh})\right]_{2}$ in $\mathrm{PhBr}$.

Figure S83. $\mathrm{t}=4 \mathrm{~h}{ }^{1} \mathrm{H}$ NMR spectrum of multicomponent coupling of bis(4-tbutylphenyl)acetylene, benzonitrile and $\left[\mathrm{py}_{2} \mathrm{TiCl}_{2}(\mathrm{NPh})\right]_{2}$ in $\mathrm{PhBr}$ after TEMPO addition.

Figure S84. $t=2 \mathrm{~h}{ }^{1} \mathrm{H}$ NMR spectrum of multicomponent coupling of bis(4-tbutylphenyl)acetylene, benzonitrile, and $\left[\mathrm{py}_{2} \mathrm{TiCl}_{2}(\mathrm{NPh})\right]_{2}$ in $\mathrm{PhBr}$ after TEMPO addition showing zoomed-in view of t-butyl peak deconvolution, with inset showing deconvolution results table. S-93 Table S1. Deconvolution results for partially overlapped t-butyl peaks, with calculations for adjusted integration area for product $1 \mathrm{j}$ peak shown.

Figure S85. Stacked ${ }^{1} \mathrm{H}$ NMR spectra characterizing the multicomponent coupling of bis(4-tbutylphenyl)acetylene, benzonitrile and $\left[\mathrm{py}_{2} \mathrm{TiCl}_{2}(\mathrm{NPh})\right]_{2}$ in $\mathrm{PhBr}$. Bottom (red trace): $\mathrm{t}=0$. Middle (green trace): $\mathrm{t}=4 \mathrm{~h}$ at $115^{\circ} \mathrm{C}$ generating metallacycle analogous to 7 , prior to TEMPO addition. Top (blue trace): $\mathrm{t}=2 \mathrm{~h}$ after TEMPO addition to give pyrazole $\mathbf{1 j}$.

Scale-up of Table 2, Entry 3 for isolation 
Figure S87. ${ }^{1} \mathrm{H}$ NMR spectra (stacked) of the $\mathrm{t}=0$ and $\mathrm{t}=22 \mathrm{~h}$ time point of the catalytic multicomponent coupling of azobenzene, 3-hexyne and $p$-tolunitrile catalyzed by $\mathrm{py}_{2} \mathrm{TiCl}_{2}(\mathrm{NPh})$. S96

Figure S88. ${ }^{1} \mathrm{H}$ NMR spectrum (alkyl region) of the $\mathrm{t}=22 \mathrm{~h}$ time point of the catalytic multicomponent coupling of azobenzene, 3 -hexyne and $p$-tolunitrile catalyzed by $\mathrm{py}_{2} \mathrm{TiCl}_{2}(\mathrm{NPh})$. S97

Figure S89. $\mathrm{t}=0$ (red), $\mathrm{t}=20 \mathrm{~h}$ (green) ${ }^{1} \mathrm{H}$ NMR spectra of the multicomponent coupling of azobenzene, 3-hexyne and $p$-tolunitrile catalyzed by $\mathrm{py}_{2} \mathrm{TiCl}_{2}(\mathrm{NPh})$ at $145{ }^{\circ} \mathrm{C}$ in $\mathrm{C}_{6} \mathrm{D}_{5} \mathrm{Br}$ compared to an independently synthesized standard of 1 (blue).

Figure S90. Stacked 1H NMR spectra (alkyl region) of the multicomponent coupling of azobenzene, 3-hexyne and p-tolunitrile catalyzed by py2TiCl2(NPh) at $145{ }^{\circ} \mathrm{C}$ in $\mathrm{C}_{6} \mathrm{D}_{5} \mathrm{Br}$ over time.

Turnover Experiment

Table S2. Diazene crossover experiment. ${ }^{a}$

Figure S91. GC-FID chromatogram characterizing the diazene turnover experiment. Figure S92. ${ }^{1} \mathrm{H}$ NMR spectrum of the reaction between $\mathrm{Li}_{2} \mathrm{ADA}^{\mathrm{Ph}} \cdot 3 \mathrm{THF}$ and $\mathrm{PhICl}_{2}$ in $\mathrm{C}_{6} \mathrm{D}_{6}$. S101

Thermolysis of $7 \mathrm{a}$ at $145^{\circ} \mathrm{C}$

Figure S93. Stacked ${ }^{1} \mathrm{H}$ NMR spectra characterizing the attempted thermolysis of $7 \mathrm{a}$ in $\mathrm{C}_{6} \mathrm{D}_{5} \mathrm{Br}$.

Top (teal trace): $\mathrm{t}=0$. Bottom (red trace): $\mathrm{t}=22 \mathrm{~h}$.

7 a decomposition at $145{ }^{\circ} \mathrm{C}$ in the presence of azobenzene

Figure S94. Stacked ${ }^{1} \mathrm{H}$ NMR spectra characterizing the attempted thermolysis of $7 \mathrm{a}$ in the presence of azobenzene in $\mathrm{C}_{6} \mathrm{D}_{5} \mathrm{Br}$. Top (teal trace): $\mathrm{t}=0$. Bottom (red trace): $\mathrm{t}=22 \mathrm{~h}$.

Reaction of 8a with $\mathrm{TiCl}_{3}(\mathrm{THF})_{3}$ Figure S95. Stacked ${ }^{1} \mathrm{H}$ NMR spectra of the reaction between $8 \mathrm{a}$ and $\mathrm{TiCl}_{3}(\mathrm{THF})_{3}$ in $\mathrm{C}_{6} \mathrm{D}_{6}$. Bottom (red trace): immediately after mixing. Top (teal trace): after the addition of pyridine.

Reaction of 8a with $\mathrm{TiCl}_{3}(\mathrm{THF})_{3}$ (NMR yields)

Figure S96. ${ }^{1} \mathrm{H}$ NMR spectrum of $8 \mathrm{a}$ and $\mathrm{TMB}$ in $\mathrm{C}_{6} \mathrm{D}_{6}$ before addition to $\mathrm{TiCl}_{3}(\mathrm{THF})_{3}$. S-105 Figure S97. ${ }^{1} \mathrm{H}$ NMR spectrum after addition of $8 \mathbf{a}$ and $\mathrm{TMB}$ to $\mathrm{TiCl}_{3}(\mathrm{THF})_{3}$ in $\mathrm{C}_{6} \mathrm{D}_{6}$. $\quad \mathrm{S}-106$

Reaction of 8 with $\mathrm{TiCl}_{4}(\mathrm{THF})_{2}$ (room temperature)

Figure S98. Stacked ${ }^{1} \mathrm{H}$ NMR spectra characterizing the addition of azirine $8 \mathbf{a}$ to $\mathrm{TiCl}_{4}(\mathrm{THF})_{2}$ in $\mathrm{C}_{6} \mathrm{D}_{6}$. Bottom (red trace): ${ }^{1} \mathrm{H}$ NMR spectrum of 8a prior to $\mathrm{TiCl}_{4}(\mathrm{THF})_{2}$ addition. Top (green trace): $\mathrm{t}=3 \mathrm{~h}$ time point after $\mathrm{TiCl}_{4}(\mathrm{THF})_{2}$ addition.

Reaction of $8 \mathrm{a}$ with $\mathrm{TiCl}_{4}(\mathrm{THF})_{2}\left(50^{\circ} \mathrm{C}\right)$ Figure S99. Stacked ${ }^{1} \mathrm{H}$ NMR spectra characterizing the reaction of $8 \mathrm{a}$ and $\mathrm{TiCl}_{4}(\mathrm{THF})_{2}$ at $50{ }^{\circ} \mathrm{C}$ in $\mathrm{C}_{6} \mathrm{D}_{6}$ over 3 hours. 109 
One-pot conversion of $8 \mathrm{a}$ to $1 \mathrm{a}$ via titanocene intermediates $9 \mathrm{a}$ and $10 \mathrm{a}$

Figure S101. Stacked ${ }^{1} \mathrm{H}$ NMR spectra characterizing the one-pot conversion of $8 \mathbf{a}$ to $1 \mathrm{a}$ via titanocene intermediates 9a and 10a. Bottom (red trace): Conversion of $\mathbf{8 a}$ to $9 \mathbf{a}$ through the reaction of $\mathbf{8 a}$ and $\mathrm{Cp}_{2} \mathrm{Ti}(\mathrm{BTMSA})$. Middle (green trace): Conversion of $9 \mathbf{a}$ to $10 \mathbf{a}$ through the addition of $\mathrm{PhICl}_{2}$. Top (blue trace): Thermal conversion of $10 \mathrm{a}$ to pyrazole $1 \mathrm{a}$ and $\mathrm{Cp}_{2} \mathrm{TiCl}_{2}$. S-110 Figure S102. ${ }^{1} \mathrm{H}$ NMR spectrum characterizing the conversion of $\mathbf{8 a}$ to $\mathbf{9 a}$ through the reaction of $8 \mathrm{a}$ and $\mathrm{Cp}_{2} \mathrm{Ti}(\mathrm{BTMSA})$.

Figure S103. ${ }^{1} \mathrm{H}$ NMR spectrum characterizing the conversion of $9 \mathrm{a}$ to $10 \mathrm{a}$ through the addition of $\mathrm{PhICl}_{2}$.

Figure S104. ${ }^{1} \mathrm{H}$ NMR spectrum characterizing the thermal conversion of $10 \mathrm{a}$ to pyrazole $1 \mathrm{a}$ and $\mathrm{Cp}_{2} \mathrm{TiCl}_{2}$ after $22 \mathrm{~h}$.

Electrochemistry Data

XRD Data

Figure S106. ORTEP diagram of (HADA) $\mathrm{TiCl}_{2}$ (S1). Thermal ellipsoids are drawn at $50 \%$ probability.

Figure S107. ORTEP diagram of $\left[\mathrm{TiCl}_{2}\left(\mathrm{ADA}^{\mathrm{Ph}}\right)\right]_{2}(6 \mathrm{a})$. Thermal ellipsoids are drawn at $50 \%$ probability.

Figure S108. ORTEP diagram of $\mathrm{py}_{2} \mathrm{TiCl}_{2}\left(\mathrm{ADA}^{\mathrm{Et}}\right)(\mathbf{7 b})$. Thermal ellipsoids are drawn at $50 \%$ probability.

Computational Methods

Figure S109. Computed structure of IM5, with HOMO and LUMO surfaces shown.

Structure: $\mathrm{py}_{3} \mathrm{TiCl}_{2}(\mathrm{NPh})$

Structure: IM3

Structure: IM4

Structure: TS2

Structure: IM5

Structure: TS3

Structure: IM6

Structure: Benzonitrile

Structure: Pyridine

Structure: 2-Butyne 


\section{General Considerations}

All air- and moisture-sensitive reactions were carried out in a nitrogen-filled glovebox unless otherwise specified. Standard solvents for air- and moisture-sensitive reactions were either deoxygenated by sparging with $\mathrm{N}_{2}$ and dried by passing through activated alumina columns of a Pure Process Technology solvent purification system (benzene, ether, pentanes, hexanes, THF, PhMe, $\left.\mathrm{CH}_{2} \mathrm{Cl}_{2}\right)$ or vacuum transferred from $\mathrm{Na} / \mathrm{Ph}_{2} \mathrm{CO}\left(\mathrm{C}_{6} \mathrm{D}_{6}\right)$ or $\mathrm{CaH}_{2}\left(\mathrm{CDCl}_{3}\right) . \mathrm{C}_{6} \mathrm{D}_{5} \mathrm{Br}$ was synthesized following literature procedure, ${ }^{1}$ degassed, dried over $\mathrm{CaH}_{2}$, and filtered through basic alumina prior to use. $\left[\mathrm{py}_{2} \mathrm{TiCl}_{2}(\mathrm{NPh})\right]_{2}{ }^{2}, \mathrm{Cp}_{2} \mathrm{Ti}(\mathrm{BTMSA})^{3}$ and $\mathrm{TiCl}_{3}(\mathrm{THF})_{3}{ }^{4}$ were synthesized according to literature procedures. Imines ${ }^{5}$ and 1-(4-methylbenzylidene)-2-phenylhydrazine 6 were synthesized according to literature procedures. 3-nitro-3-hexene was synthesized through a Henry reaction to make the corresponding $\beta$-hydroxy nitro compound, followed by dehydration to the nitroolefin. Liquid alkynes and nitriles were freeze-pump-thaw degassed three times and passed through activated basic alumina prior to use. Azobenzene and TEMPO were sublimed prior to use. All other reagents were put under vacuum overnight prior to use or otherwise used as purchased. ${ }^{1} \mathrm{H}$ and ${ }^{13} \mathrm{C}$ NMR spectra were recorded on Bruker Avance III HD 400 and $500 \mathrm{MHz}$ spectrometers. Chemical shifts were referenced to the residual protio-solvent impurity for ${ }^{1} \mathrm{H}\left(\mathrm{s}, 7.16 \mathrm{ppm}\right.$ for $\mathrm{C}_{6} \mathrm{D}_{5} \mathrm{H} ; \mathrm{s}, 7.26$ for $\mathrm{CHCl}_{3}$; s $7.30 \mathrm{ppm}$, $7.02 \mathrm{ppm}$ and $6.94 \mathrm{ppm}$ for $\left.\mathrm{C}_{6} \mathrm{D}_{4} \mathrm{HBr}^{7}\right)$ and solvent carbons for ${ }^{13} \mathrm{C}\left(\mathrm{t}, 128.1 \mathrm{ppm}\right.$ for $\mathrm{C}_{6} \mathrm{D}_{6} ; \mathrm{t}, 77.2 \mathrm{ppm}$ for $\mathrm{CDCl}_{3}$ ). Qualitative GC MS spectra were recorded on an Agilent GC6890N-MSD5975 gas chromatograph-mass spectrometer fitted with a 7683 auto sampler. A HD- 5 column ( $5 \%$ diphenyl siloxane in the polymer) was used in the gas chromatograph and electron ionization technique was used for mass spectrometry detection. GC chromatographs were collected on an Agilent 7890B GC system equipped with an HP-5 column ( $30 \mathrm{~m}, 0.32 \mathrm{~mm}, 0.25 \mu \mathrm{m}, 7$ in cage), an oxidation-methanation reactor (Polyarc $®$ System, Activated Research Company) and an FID detector for quantitative carbon detection.

\section{Synthesis of Compounds}

\section{2-methyl-3-phenyl-3-(phenylimino)-1-(p-tolyl)prop-1-en-1-amine (4a)}

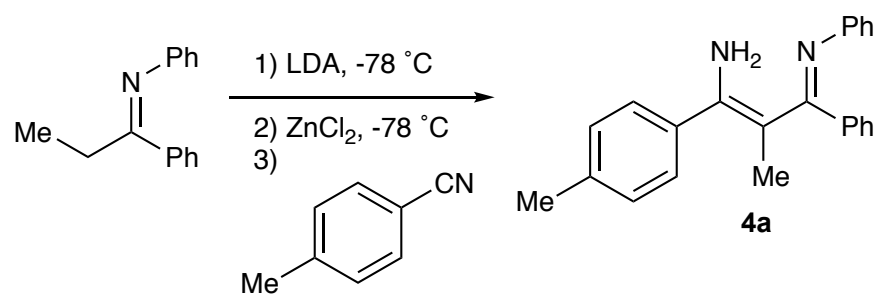

A $~ 0.2 \mathrm{M}$ LDA solution was prepared from diisopropylamine $(2.25 \mathrm{~mL}, 16.1 \mathrm{mmol}, 1.01$ equiv.) and $2.5 \mathrm{M} \mathrm{nBuLi}(6.4 \mathrm{~mL}, 16 \mathrm{mmol}, 1$ equiv.) in THF. This solution was cannula transferred to a solution of $\mathrm{N}, 1$-diphenyl-1-propanimine (3.02 g, $14.4 \mathrm{mmol}, 1$ equiv.) in $100 \mathrm{~mL}$ THF at $-78^{\circ} \mathrm{C}$. After 15 minutes, a slurry of anhydrous $\mathrm{ZnCl}_{2}\left(4.09 \mathrm{~g}, 30.0 \mathrm{mmol}, 2.08\right.$ equiv.) in $\mathrm{Et}_{2} \mathrm{O}(50 \mathrm{~mL})$ was cannula transferred to the reaction pot at $-78{ }^{\circ} \mathrm{C}$. The cooling bath was removed, and as the reaction warmed, $p$-tolunitrile (2.23 g, $19 \mathrm{mmol}, 1.32$ equiv.) was added via syringe to give a pale yellow solution. This reaction was allowed to stir overnight at room temperature, followed by a 2 hour period of heating to reflux. The mixture was cooled, then poured into $2 \mathrm{M} \mathrm{NaOH}$, extracted with $\mathrm{Et}_{2} \mathrm{O}(3 \times 100 \mathrm{~mL})$, dried over $\mathrm{Na}_{2} \mathrm{SO}_{4}$ and the solvent removed using a rotovap to give a yellow solid contaminated with residual $p$-tolunitrile. This solid was dissolved in minimal hot EtOH and stored at $-35^{\circ} \mathrm{C}$ overnight to give pale yellow needles of the title compound, which were washed with cold ether ( $3.3 \mathrm{~g}, 51 \%$ yield). ${ }^{1} \mathbf{H ~} \mathbf{~ N M R}$ ( $400 \mathbf{~ M H z}$, $\mathrm{CDCl}_{3}$ ): $\delta$ 7.5-8 (s (br), 2H, Ar-H and $\left.\mathrm{N}-H\right), 7.43(\mathrm{~d}, 2.5 \mathrm{H}, \mathrm{Ar}-\mathrm{H}), 7.0-7.3\left(\mathrm{~m}, 8 \mathrm{H}\right.$ (overlap with $\mathrm{CHCl}_{3}$ ), 
$\mathrm{Ar}-\mathrm{H}), 6.70-6.95(\mathrm{~m}, 3.5 \mathrm{H}, \mathrm{Ar}-\mathrm{H}), 2.43\left(\mathrm{~s}, 3 \mathrm{H}, \mathrm{Ar}-\mathrm{CH}_{3}\right), 1.57$ (s, 3H, $\left.\mathrm{CH}_{3}\right) .{ }^{13} \mathrm{C}$ NMR (100 MHz, $\left.\mathrm{CDCl}_{3}\right): \delta 174.99,153.81,151.31,138.03,137.77,129.01,128.64,122.09,120.87,96.95,24.95$, 21.29, 16.38, 12.96. ESI-HRMS (m/z): calcd. for $\mathrm{C}_{23} \mathrm{H}_{23} \mathrm{~N}_{2}{ }^{+}, 327.1856$; found, 327.1847.
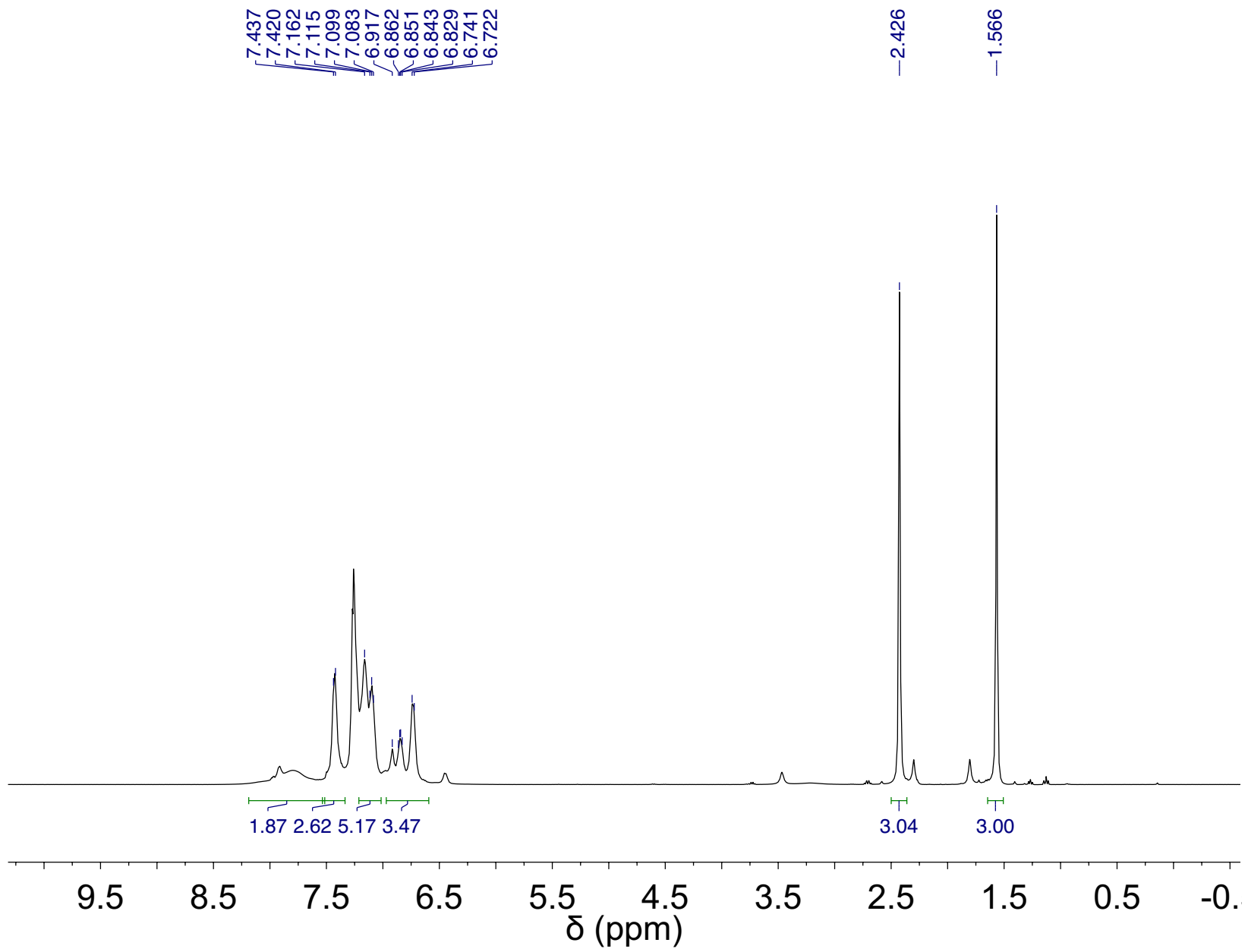

Figure S1. 1H NMR spectrum of $4 a$ in $\mathrm{CDCl}_{3}$. 

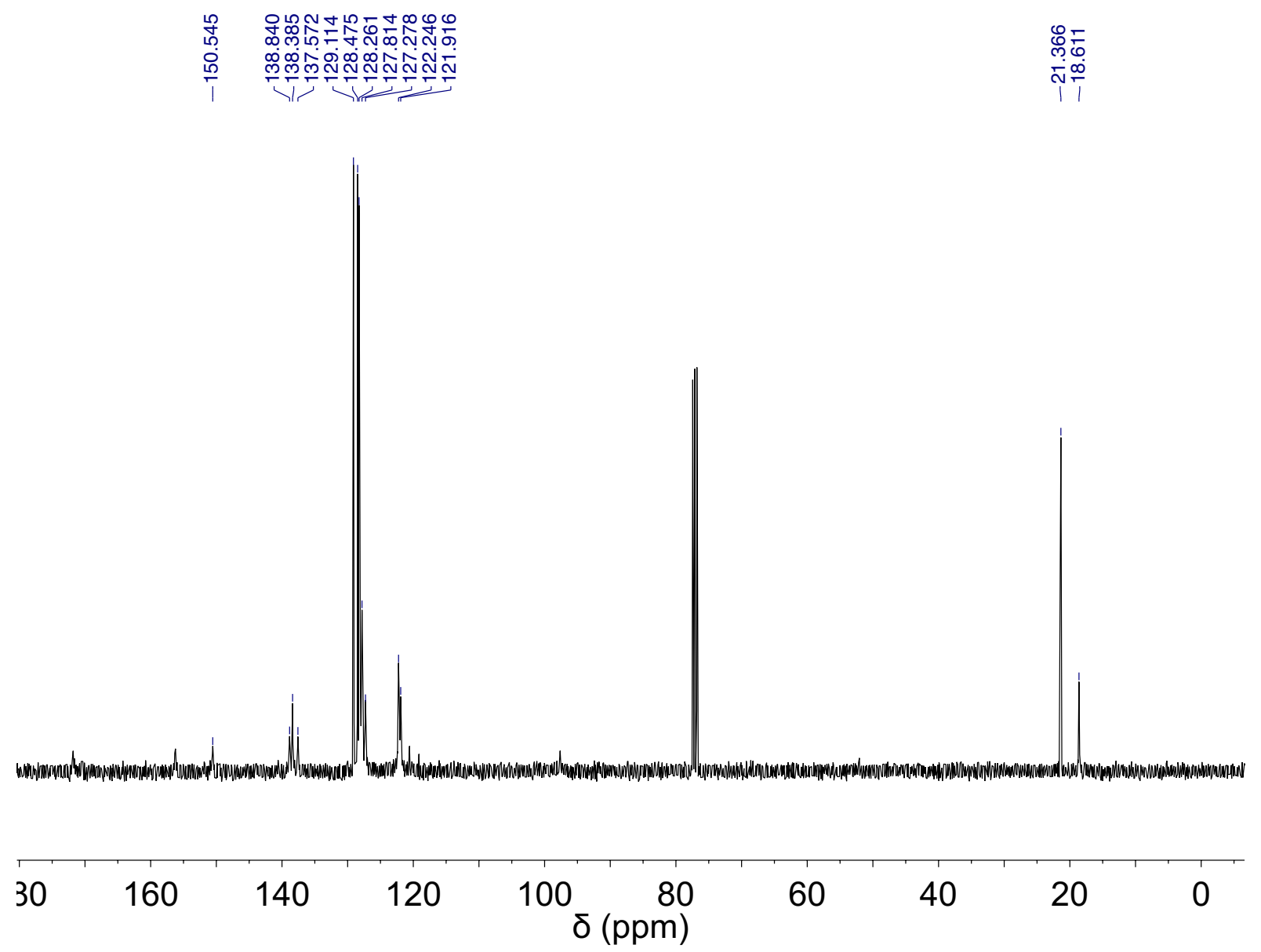

Figure S2. ${ }^{13} \mathrm{C}$ NMR Spectrum of $4 \mathrm{a}$ in $\mathrm{CDCl}_{3}$.

2-methyl-3-(phenylimino)-1-(p-tolyl)pent-1-en-1-amine (4b)<smiles>CCC(CC)=Nc1ccccc1</smiles>

A 0.2 M LDA solution was prepared from diisopropylamine (3.40 mL, $24.3 \mathrm{mmol}, 1.1$ equiv.) and $2.5 \mathrm{M} \mathrm{nBuLi}(9.7 \mathrm{~mL}, 24 \mathrm{mmol}, 1.0$ equiv.) in THF. This solution was cannula transferred to a solution of N-phenyl-3-pentanimine (3.7 g, $23 \mathrm{mmol}, 1$ equiv.) in $100 \mathrm{~mL}$ THF at $-78{ }^{\circ} \mathrm{C}$. After 15 minutes, a slurry of anhydrous $\mathrm{ZnCl}_{2}$ in $\mathrm{Et}_{2} \mathrm{O}(50 \mathrm{~mL})$ was cannula transferred to the reaction pot at $-78{ }^{\circ} \mathrm{C}$. The cooling bath was removed, and as the reaction warmed, $p$-tolunitrile ( $3.6 \mathrm{~g}, 31 \mathrm{mmol}, 1.3 \mathrm{equiv}$.) was added via syringe to give a pale yellow solution. This reaction was allowed to stir overnight at room temperature, followed by a 6 hour period of heating to reflux. The mixture was then poured into $2 \mathrm{M}$ $\mathrm{NaOH}$, extracted with $\mathrm{Et}_{2} \mathrm{O}(3 \times 100 \mathrm{~mL})$, dried over $\mathrm{Na}_{2} \mathrm{SO}_{4}$ and the solvent removed using a rotovap to give a yellow solid contaminated with residual $p$-tolunitrile. This solid was dissolved in minimal hot $\mathrm{EtOH}$ and stored at $-35{ }^{\circ} \mathrm{C}$ overnight to give pale yellow microcrystals of the title compound, which 
were washed with cold ether (3.3 g, 51\% yield). ${ }^{1} \mathrm{H}$ NMR (400 MHz, $\left.\mathbf{C D C l}_{3}\right)$ : $\delta$ 7.6-7.2 (m (br), 6H, Ar$H$ and $\mathrm{N}-H$ ), $7.22(\mathrm{~d}, 2 \mathrm{H}, \mathrm{Ar}-\mathrm{H}), 7.03(\mathrm{t}, 1 \mathrm{H}, \mathrm{Ar}-\mathrm{H}), 6.86(\mathrm{~d}, 2 \mathrm{H}, \mathrm{Ar}-\mathrm{H}), 2.40$ (m (overlapped quartet and singlet), $5 \mathrm{H}, \mathrm{CH}_{2} \mathrm{CH}_{3}$ and $\mathrm{Me}$ ), $1.83(\mathrm{~s}, 3 \mathrm{H}, \mathrm{Me}), 1.06\left(\mathrm{t}, 3 \mathrm{H}, \mathrm{CH}_{2} \mathrm{CH}_{3}\right) .{ }^{13} \mathrm{C}$ NMR (100 MHz, $\left.\mathrm{CDCl}_{3}\right): \delta 175.13,153.95,151.45,138.17,137.90,129.14,128.78,128.41,122.22,121.01,97.09$, 25.08, 21.43, 16.52, 13.10. ESI-HRMS (m/z): calcd. for $\mathrm{C}_{19} \mathrm{H}_{23} \mathrm{~N}_{2}{ }^{+}, 279.1861$; found, 279.1860 .
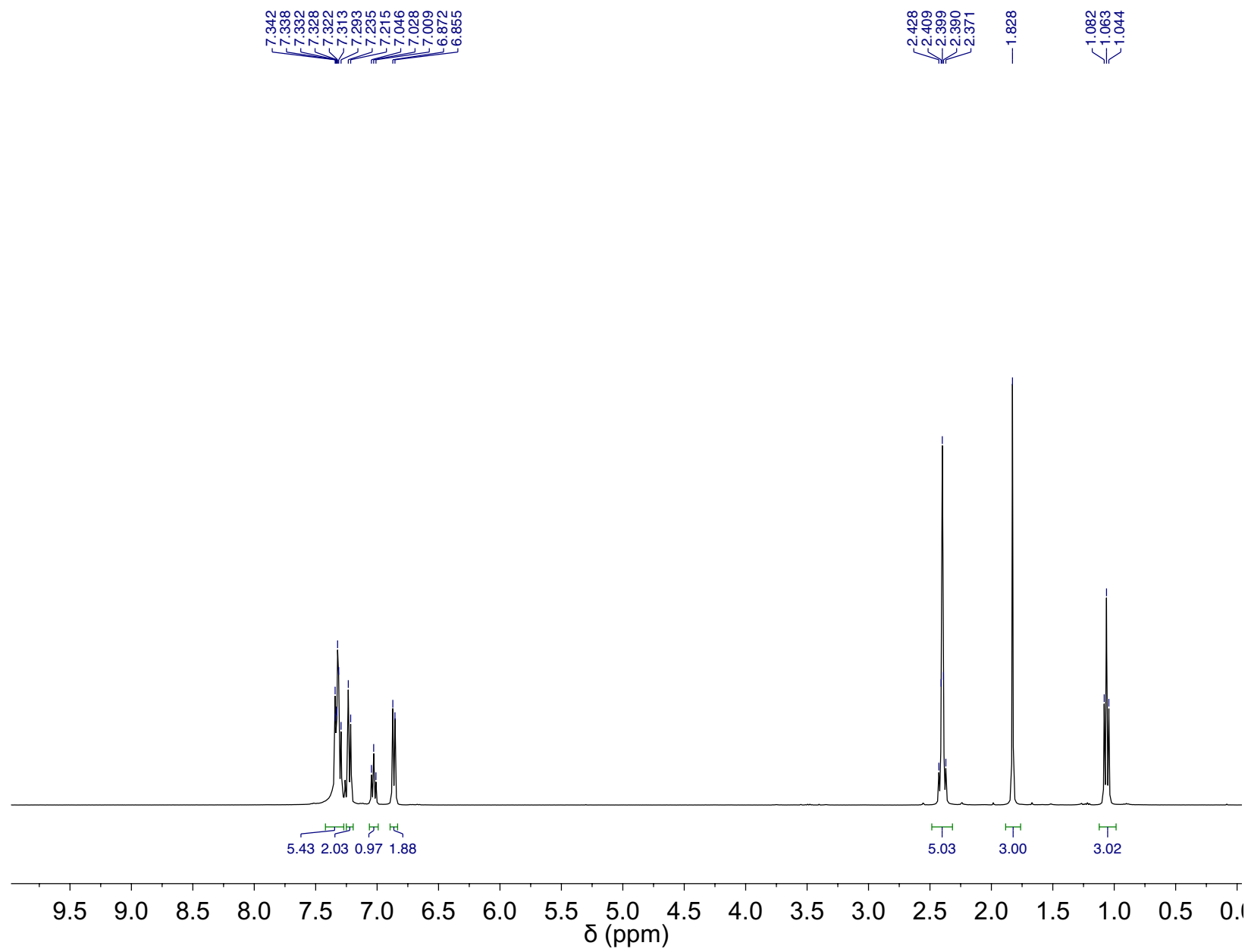

Figure S3. ${ }^{1} \mathrm{H}$ NMR spectrum of $4 \mathbf{b}$ in $\mathrm{CDCl}_{3}$. 


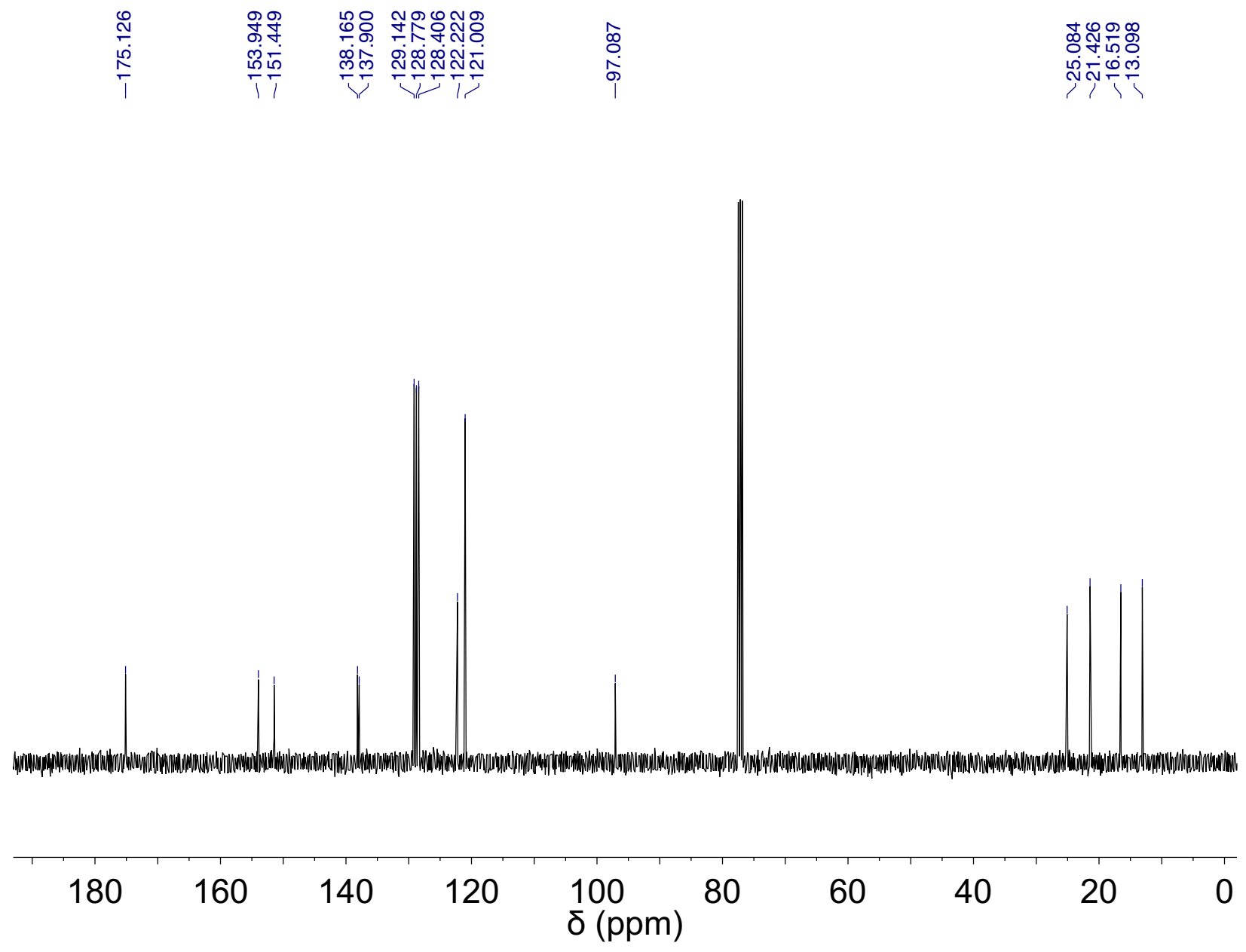

Figure S4. ${ }^{13} \mathrm{C}$ NMR spectrum of $4 b$ in $\mathrm{CDCl}_{3}$.

$\left(\mathrm{HNMe}_{2}\right) \mathrm{TiCl}_{2}\left(\mathrm{ADA}^{\mathrm{Ph}}\right)(\mathbf{5 a})$

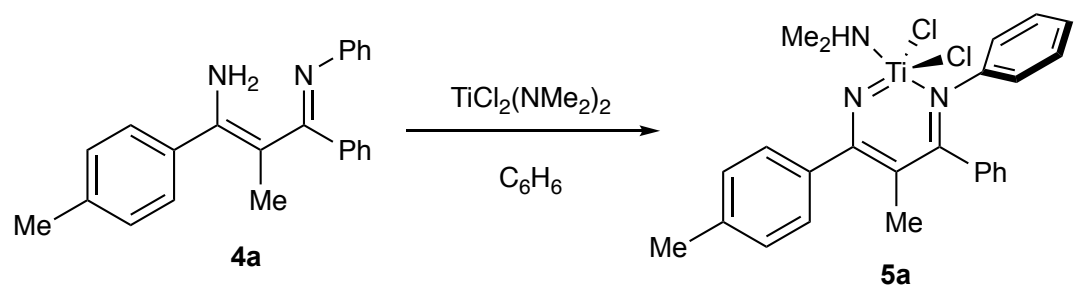

$\mathrm{TiCl}_{2}\left(\mathrm{NMe}_{2}\right)_{2}$ (40.5 mg, $0.196 \mathrm{mmol}, 1$ equiv.) and $4 \mathrm{a}(63.9 \mathrm{mg}, 0.196 \mathrm{mmol}, 1.00$ equiv.) were massed out into the same vial. Benzene $(4 \mathrm{~mL})$ was added to vial, and the solution was stirred. The solution initially appears dark purple, but upon stirring quickly turns dark orange. After overnight stirring, the reaction appears dark green. The volatiles were removed under vacuum to give a dark solid, that can be scraped and transferred to a new vial as pure $5 \mathrm{a}(44.1 \mathrm{mg}, 46.1 \%)$. ${ }^{1} \mathbf{H}$ NMR (500 $\left.\mathbf{M H z}, \mathbf{C}_{6} \mathrm{D}_{6}\right): \delta 7.51(\mathrm{~d}, 2 \mathrm{H}, \mathrm{Ar}-H), 7.28(\mathrm{~d}, 2 \mathrm{H}, \mathrm{Ar}-\mathrm{H}), 6.92(\mathrm{~m}, 4 \mathrm{H}, \mathrm{Ar}-\mathrm{H}), 6.80(\mathrm{~m}, 4 \mathrm{H}, \mathrm{Ar}-\mathrm{H}), 6.70$ $(\mathrm{m}, 1 \mathrm{H}, \mathrm{Ar}-\mathrm{H}), 6.63$ (t, 1H, Ar-H), 2.10-2.35 (br, 7H, $\left.\mathrm{HN}\left(\mathrm{CH}_{3}\right)_{2}\right), 2.07$ (s, 3H, Me), $1.75(\mathrm{~s}, 3 \mathrm{H}, \mathrm{Me})$. ${ }_{13} \mathrm{C}$ NMR (100 MHz, $\left.\mathrm{C}_{6} \mathrm{D}_{6}\right)$ : $\delta$ 176.76, 170.96, 147.43, 139.32, 138.86, 133.64, 129.17, 128.91, 128.59, 
127.71, 127.53, 125.42, 121.98, 21.22, 19.98. Anal. Calcd. $\mathrm{C}_{25} \mathrm{H}_{27} \mathrm{Cl}_{2} \mathrm{~N}_{3} \mathrm{Ti}(\%): \mathrm{C}, 61.50 ; \mathrm{H}, 5.57 ; \mathrm{N}$, 8.61. Found: C, 58.38; H, 5.63; N, 8.06.

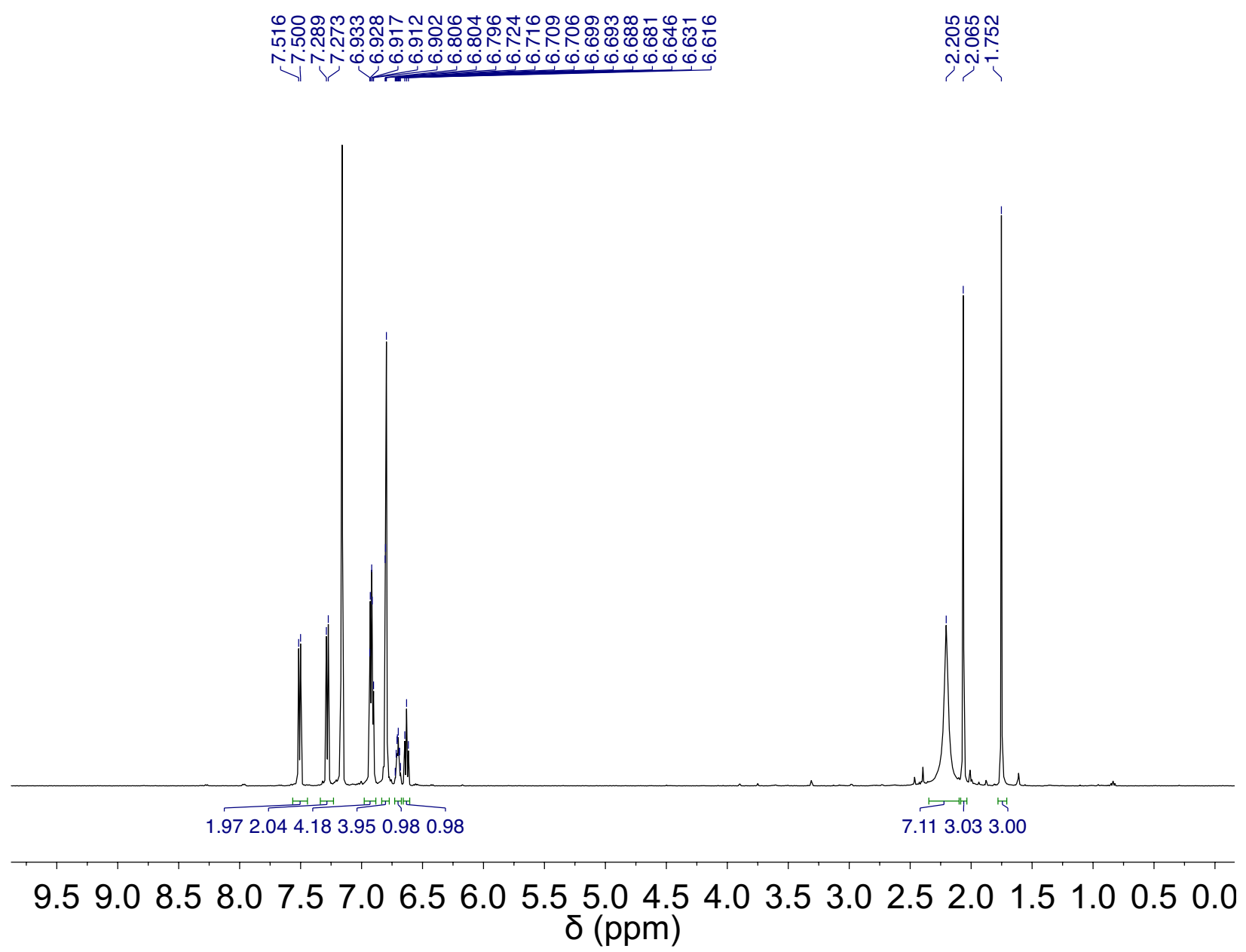

Figure S5. ${ }^{1} \mathrm{H}$ NMR spectrum of $5 \mathrm{a}$ in $\mathrm{C}_{6} \mathrm{D}_{6}$. 


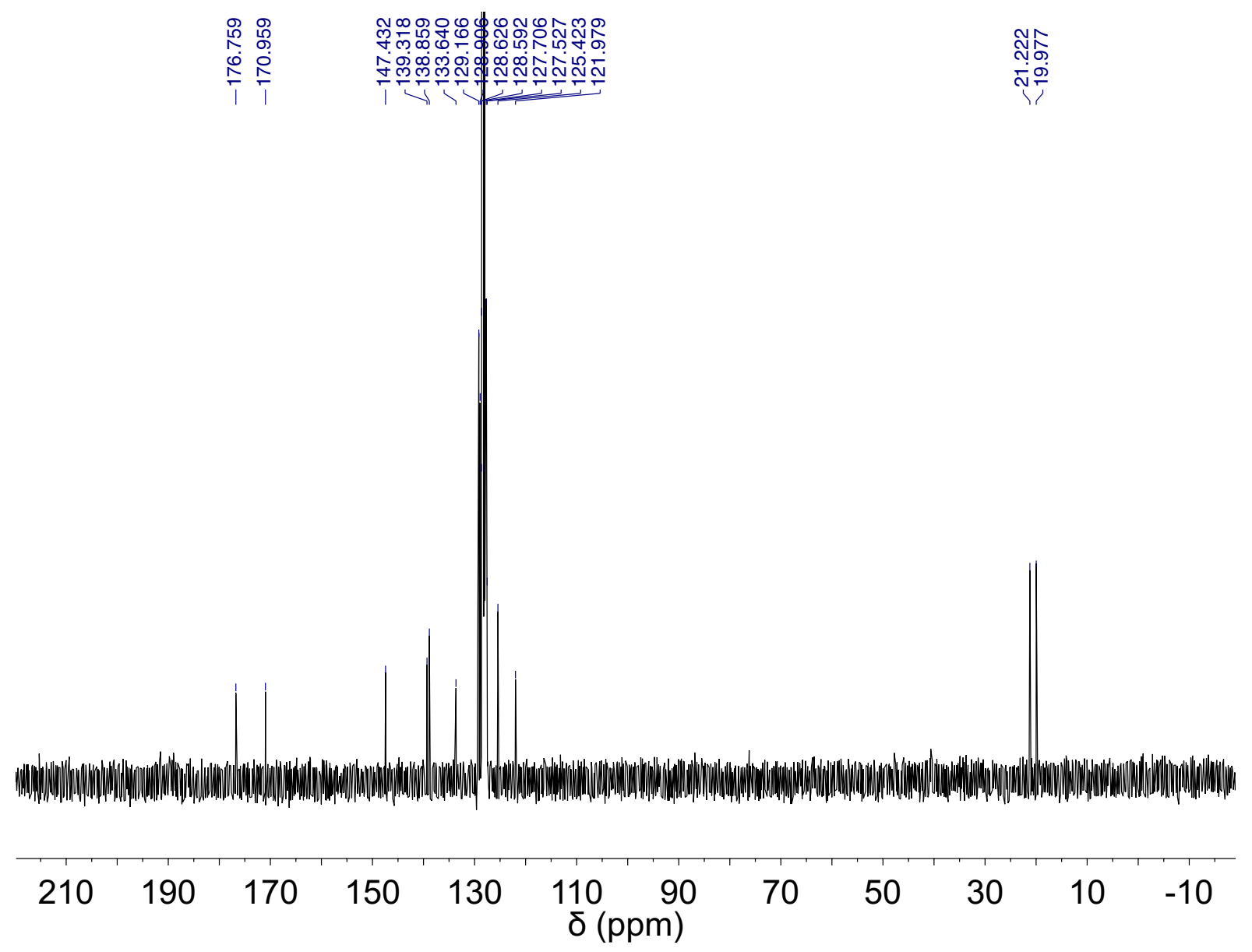

Figure S6. ${ }^{13} \mathrm{C}$ NMR spectrum of $5 \mathrm{a}$ in $\mathrm{C}_{6} \mathrm{D}_{6}$.

$\mathrm{py}_{2} \mathrm{TiCl}_{2}\left(\mathrm{ADA}^{\mathrm{Ph}}\right)(7 \mathrm{a})$

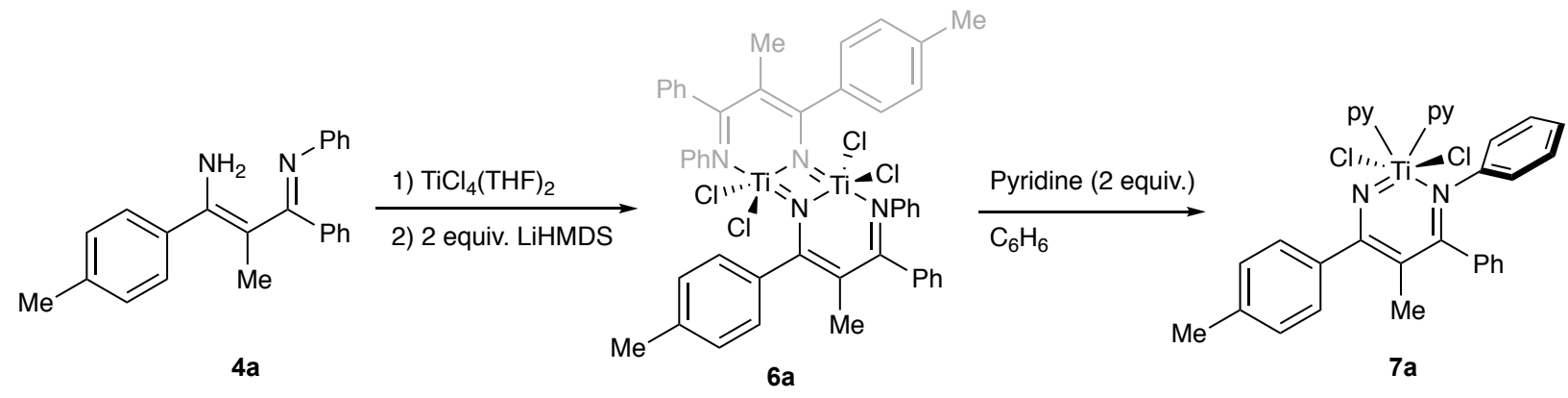

A yellow solution of $4 \mathrm{a}\left(327 \mathrm{mg}, 1.00 \mathrm{mmol}, 1.00\right.$ equiv.) in THF $(5 \mathrm{~mL})$ at $-35{ }^{\circ} \mathrm{C}$ was added dropwise to a stirring yellow slurry of $\mathrm{TiCl}_{4}(\mathrm{THF})_{2}(333 \mathrm{mg}, 1.00 \mathrm{mmol}, 1$ equiv.) in $\mathrm{THF}(5 \mathrm{~mL})$ at -35 ${ }^{\circ} \mathrm{C}$ to immediately give a deep purple solution. After approximately 5 minutes, a $-35{ }^{\circ} \mathrm{C}$ solution of LiHMDS (334 mg, 2.00 mmol, 2.00 equiv.) in THF (3 mL) was added via pipette, which gives a brown solution. This solution was allowed to stir for 2 hours, after which the volatiles were removed under vacuum. The residue was taken up in benzene and filtered through celite (two portions, $15 \mathrm{~mL}$ total) 
to give a dark orange-brown solution. This solution is concentrated to approximately $10 \mathrm{~mL}$, and transferred to a $20 \mathrm{~mL}$ scintillation vial. Pyridine is added (2 equiv.), swirled to combine, and the solution was allowed to stand for several days, after which several black microcrystals formed (182 $\mathrm{mg}, 0.303 \mathrm{mmol}, 30.3 \%$ yield). The mother liquor can be concentrated and stored for more crystals. (Note: Crystals appear black, but small crystals under polarized light when viewed under a microscope are green-yellow. Solutions in dry, aromatic solvents initially appear purple, but as sample becomes more concentrated as more of the crystals dissolve the solution becomes dark green-yellow). ${ }^{1} \mathbf{H}$ NMR (400 MHz, $\left.\mathrm{C}_{6} \mathrm{D}_{6}\right)$ : $\delta$ 8.5-9.0 (br, 4H, py), 7.52 (d, 2H, Ar-H), 7.40 (d, 2H, Ar-H), 6.81-6.92 (m, 8H, Ar$H$ ), $6.71(\mathrm{t}, 1 \mathrm{H}, \mathrm{Ar}-\mathrm{H}), 6.57(\mathrm{t}, 1 \mathrm{H}, \mathrm{Ar}-\mathrm{H}), 6.2-6.9$ (br, 6H, py), $2.04(\mathrm{~s}, 3 \mathrm{H}, \mathrm{Me}), 1.84(\mathrm{~s}, 3 \mathrm{H}, \mathrm{Me}) .{ }^{13} \mathrm{C}$ NMR (100 MHz, $\left.\mathrm{C}_{6} \mathrm{D}_{6}\right): \delta 176.13,170.82,151.06,148.71,139.82,138.60,133.93,129.26,128.88$, 128.71, 127.53, 127.32, 124.99, 123.9-123.2 (br), 123.27, 21.22, 20.08 (py ${ }^{13} \mathrm{C}$ shift expected near $\sim 135 \mathrm{ppm}$ not observed, two missing ${ }^{13} \mathrm{C}$ shifts expected to be overlapped by $\mathrm{C}_{6} \mathrm{D}_{6}$ ). Anal. Calcd. $\mathrm{C}_{33} \mathrm{H}_{30} \mathrm{Cl}_{2} \mathrm{~N}_{4} \mathrm{Ti}(\%): \mathrm{C}, 65.91 ; \mathrm{H}, 5.03 ; \mathrm{N}, 9.32$. Found: C, 63.54; H, 5.08; N, 9.09.

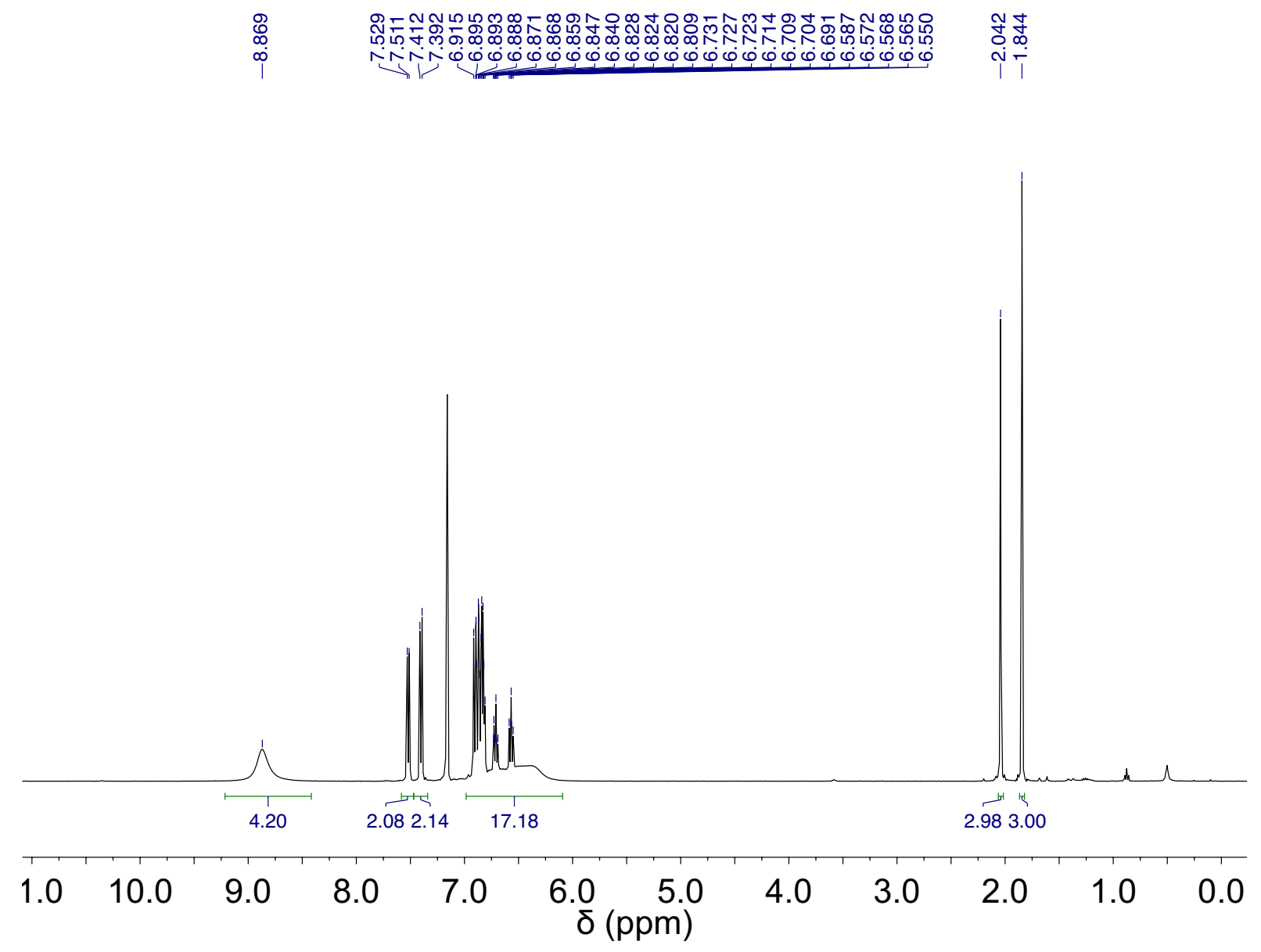

Figure S7. ${ }^{1} \mathrm{H}$ NMR spectrum of $7 \mathrm{a}$ in $\mathrm{C}_{6} \mathrm{D}_{6}$. 


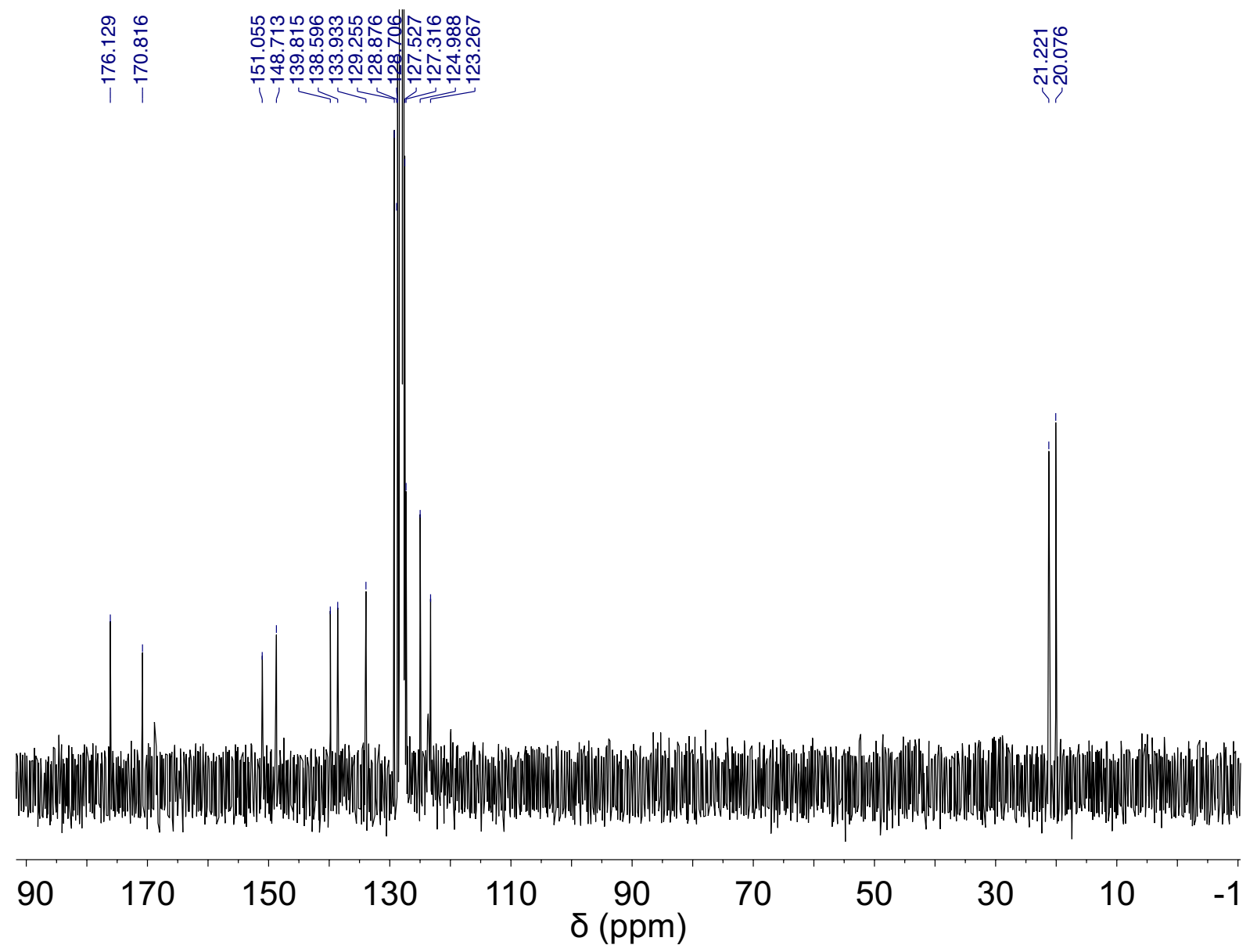

Figure S8. ${ }^{13} \mathrm{C}$ NMR spectrum of $7 \mathrm{a}$ in $\mathrm{C}_{6} \mathrm{D}_{6}$.

$\mathrm{py}_{2} \mathrm{TiCl}_{2}\left(\mathrm{ADA}^{\mathrm{Et}}\right)(7 \mathrm{~b})$

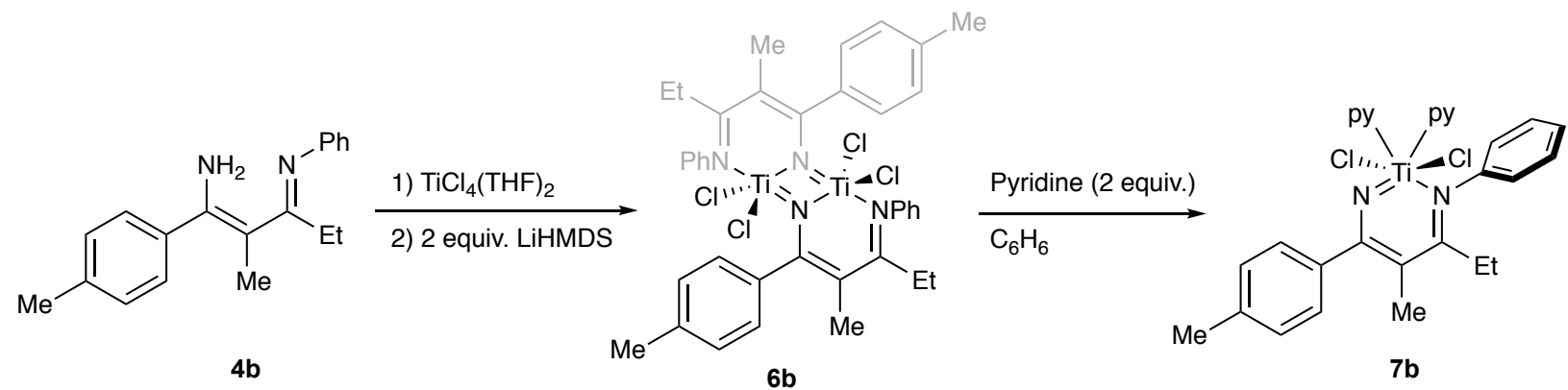

A yellow solution of $\mathbf{4 b}\left(479 \mathrm{mg}, 1.72 \mathrm{mmol}, 1.00\right.$ equiv.) in THF $(5 \mathrm{~mL})$ at $-35{ }^{\circ} \mathrm{C}$ was added dropwise to a stirring yellow slurry of $\mathrm{TiCl}_{4}(\mathrm{THF})_{2}(574 \mathrm{mg}, 1.72 \mathrm{mmol}, 1$ equiv. $)$ in $\mathrm{THF}(5 \mathrm{~mL})$ at -35 ${ }^{\circ} \mathrm{C}$ to immediately give a deep purple solution. After approximately 5 minutes, a $-35{ }^{\circ} \mathrm{C}$ solution of LiHMDS (575 mg, 3.44 mmol, 2.00 equiv.) in THF (3 mL) was added via pipette, which gives a brown solution. This solution was allowed to stir for 2 hours, after which the volatiles were removed under vacuum. The residue was taken up in benzene and filtered through Celite (two portions, $15 \mathrm{~mL}$ total) to give a dark orange-brown solution. This solution was concentrated to approximately $10 \mathrm{~mL}$ and transferred to a $20 \mathrm{~mL}$ scintillation vial. Pyridine was added $(\sim 0.5 \mathrm{~mL})$, swirled to combine, and the 
solution was allowed to stand for several days, after which several large, black, block crystals formed (304 mg, $0.549 \mathrm{mmol}, 31.9 \%$ yield). The mother liquor can be concentrated and stored for more crystals. (Note: Crystals appear black, but small crystals under polarized light when viewed under a microscope are amber. Solutions in dry, aromatic solvents initially appear purple, but as sample becomes more concentrated as more of the crystals dissolve the solution becomes dark amber). ${ }^{1} \mathbf{H}$ NMR (400 MHz, CDCl $): \delta 8.92$ (br, 2H, py), 8.79 (br, 2H, py), $7.86(\mathrm{~d}, 2 \mathrm{H}, \mathrm{Ar}-H), 7.33(\mathrm{~d}, 2 \mathrm{H}, \mathrm{Ar}-\mathrm{H})$, 7.26 (d, 2H, Ar-H), 7.00 (m, 3H, Ar-H), 6.71 (br, 3H, py), 6.37 (br, 3H, py), 2.30 (q, 2H, $\left.\mathrm{CH}_{3} \mathrm{CH}_{2}\right), 2.15$ (s, 3H, Me), 2.03 (s, 3H, Me), $0.94\left(\mathrm{t}, 3 \mathrm{H}, \mathrm{CH}_{3} \mathrm{CH}_{2}\right.$ ). $\left.{ }^{13} \mathrm{C} \mathrm{NMR} \mathrm{(100} \mathrm{MHz,} \mathrm{CDCl}_{3}\right)$ : $\delta$ 178.30, 169.60, 150.6(br), 146.53, 138.57, 133.08, 128.86, 128.48, 128.10, 127.58, 125.86, 123.42, 124.5(br), 123.7(br), 123.14, 26.71, 21.49, 17.85, 12.40. Anal. Calcd. $\mathrm{C}_{29} \mathrm{H}_{30} \mathrm{Cl}_{2} \mathrm{~N}_{4} \mathrm{Ti}(\%): \mathrm{C}, 62.95 ; \mathrm{H}, 5.46 ; \mathrm{N}$, 10.13. Found: C, 62.90; H, 5.53; N, 10.13.

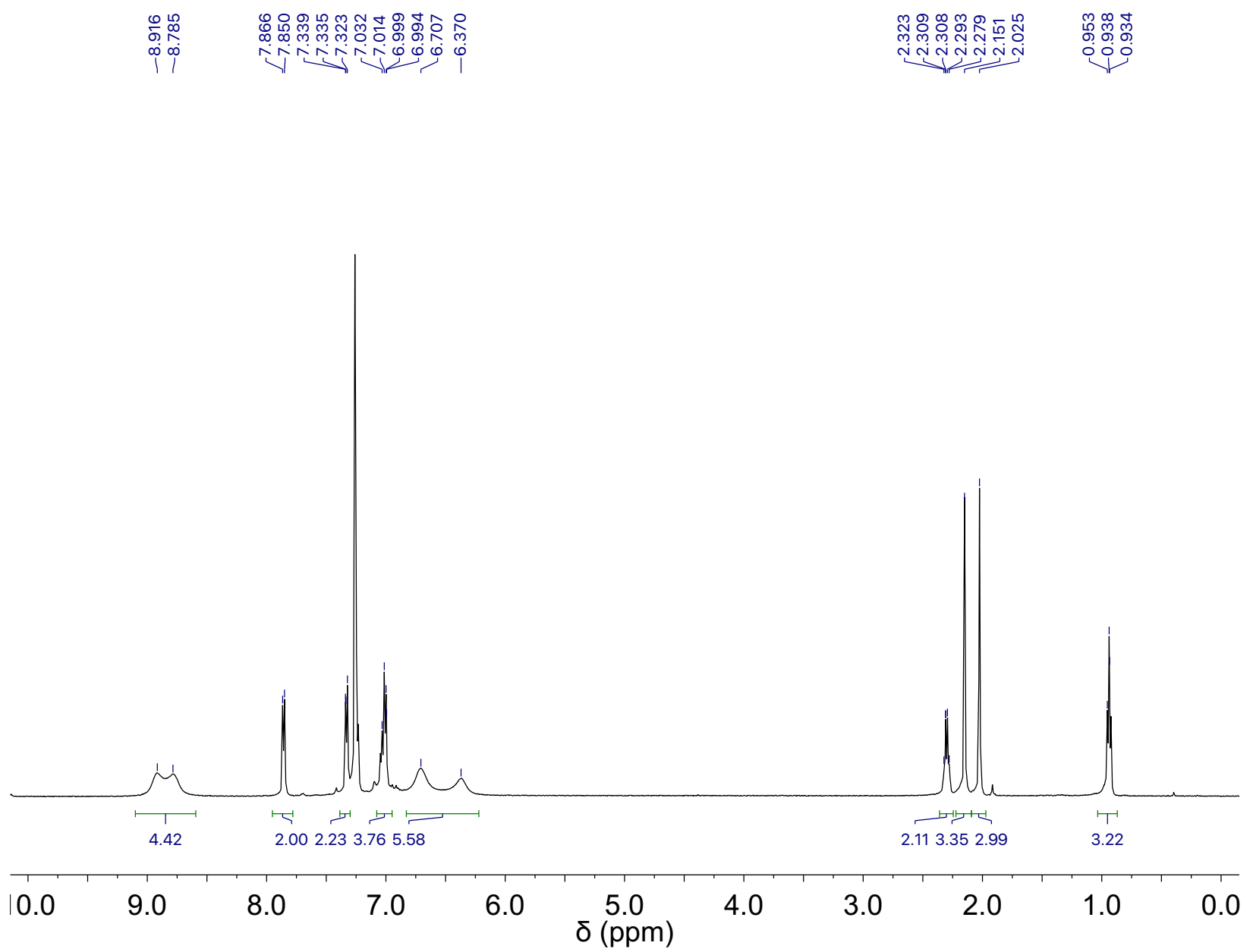

Figure S9. ${ }^{1} \mathrm{H}$ NMR spectrum of $7 \mathbf{b}$ in $\mathrm{CDCl}_{3}$. 


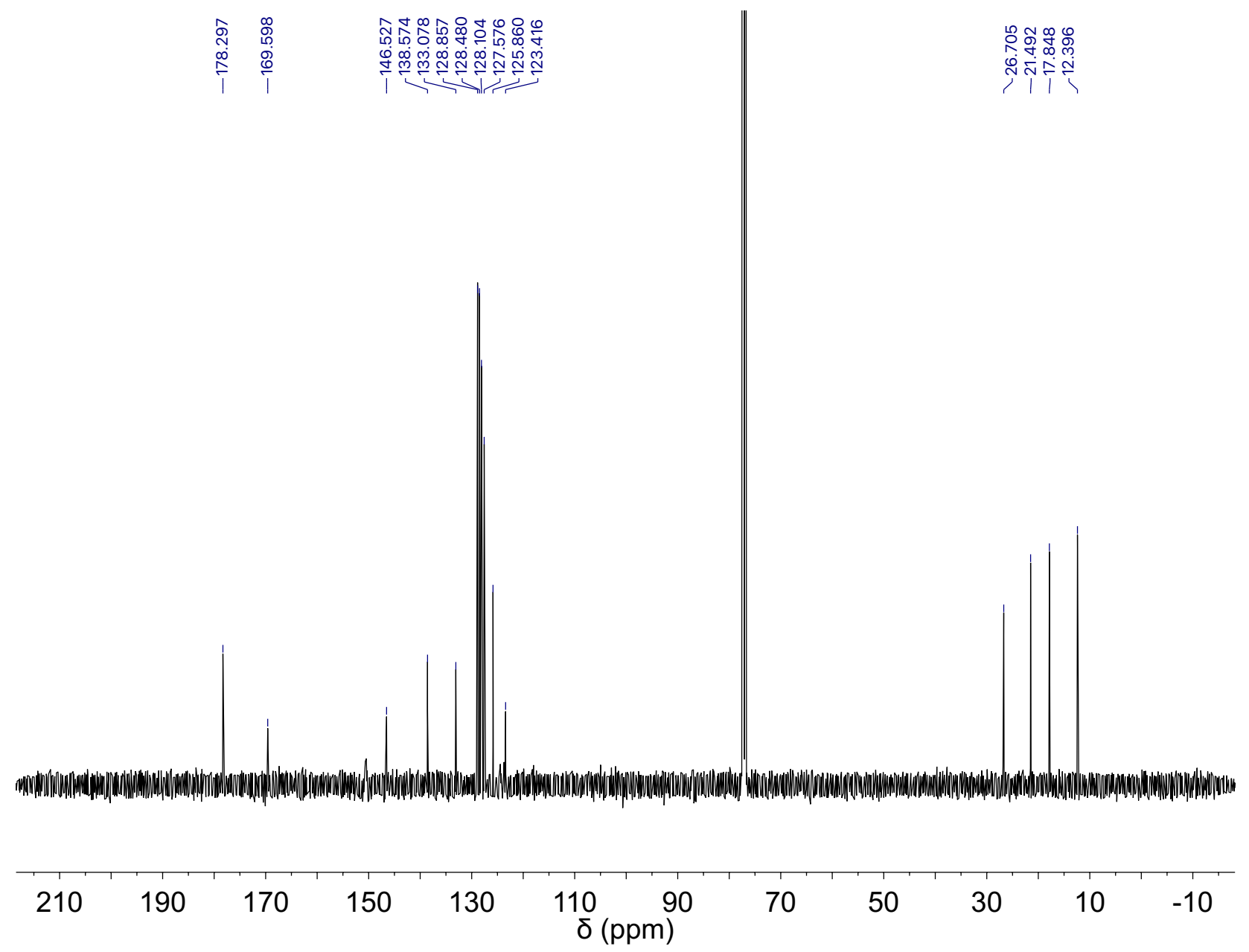

Figure $\mathbf{S 1 0} .{ }^{13} \mathrm{C}$ NMR spectrum of $7 \mathbf{b}$ in $\mathrm{CDCl}_{3}$.

\section{1-(2-methyl-3-(p-tolyl)-2H-azirin-2-yl)-N,1-diphenylmethanimine (8a)}<smiles>CCCOC(C)CCOc1ccccc1</smiles>

4a (171 mg, $0.524 \mathrm{mmol}, 1$ equiv.) and PIDA (180 mg, $0.559 \mathrm{mmol}, 1.07$ equiv.) were massed out into the same $20 \mathrm{~mL}$ scintillation vial. DCM $(10 \mathrm{~mL})$ was added, and the solution was stirred. Triethylamine ( $160 \mu \mathrm{L}, 1.1 \mathrm{mmol}, 2.1$ equiv.) was added to the stirring solution dropwise via syringe, which immediately lightened the solution to a pale yellow. The reaction was allowed to stir for one hour, after which the reaction mixture was dried under vacuum to obtain a residue, which was purified using a Teledyne CombiFlash to obtain $8 \mathbf{8 a}\left(61 \mathrm{mg}, 36 \%\right.$ yield). $\left.{ }^{1} \mathbf{H} \mathbf{~ N M R ~ ( 5 0 0 ~ M H z , ~} \mathbf{C D C l}_{3}\right): \delta 7.71$ (d, $2 \mathrm{H}, \mathrm{Ar}-H), 7.33(\mathrm{~d}, 2 \mathrm{H}, \mathrm{Ar}-H), 7.07(\mathrm{t}, 2 \mathrm{H}, \mathrm{Ar}-H), 7.01(\mathrm{~m}, 3 \mathrm{H}, \mathrm{Ar}-H), 6.84(\mathrm{~m}, 3 \mathrm{H}, \mathrm{Ar}-H), 6.63(\mathrm{~d}, 2 \mathrm{H}$, $\mathrm{Ar}-\mathrm{H}), 2.44$ (s, 3H, $\left.\mathrm{Ar}-\mathrm{CH}_{3}\right), 1.79$ (s, 3H, $\left.\mathrm{CH}_{3}\right) .{ }^{13} \mathrm{C}$ NMR (100 MHz, $\left.\mathrm{CDCl}_{3}\right): \delta$ 174.28, 168.82, 151.23, 
144.18, 135.53, 130.09, 129.70, 128.33, 128.06, 127.86, 127.74,122.95, 121.95, 120.88, 42.59, 22.01, 19.91. ESI-HRMS (m/z): calcd. for $\mathrm{C}_{23} \mathrm{H}_{20} \mathrm{~N}_{2} \mathrm{Na}^{+}$, 347.1524; found, 347.1545.
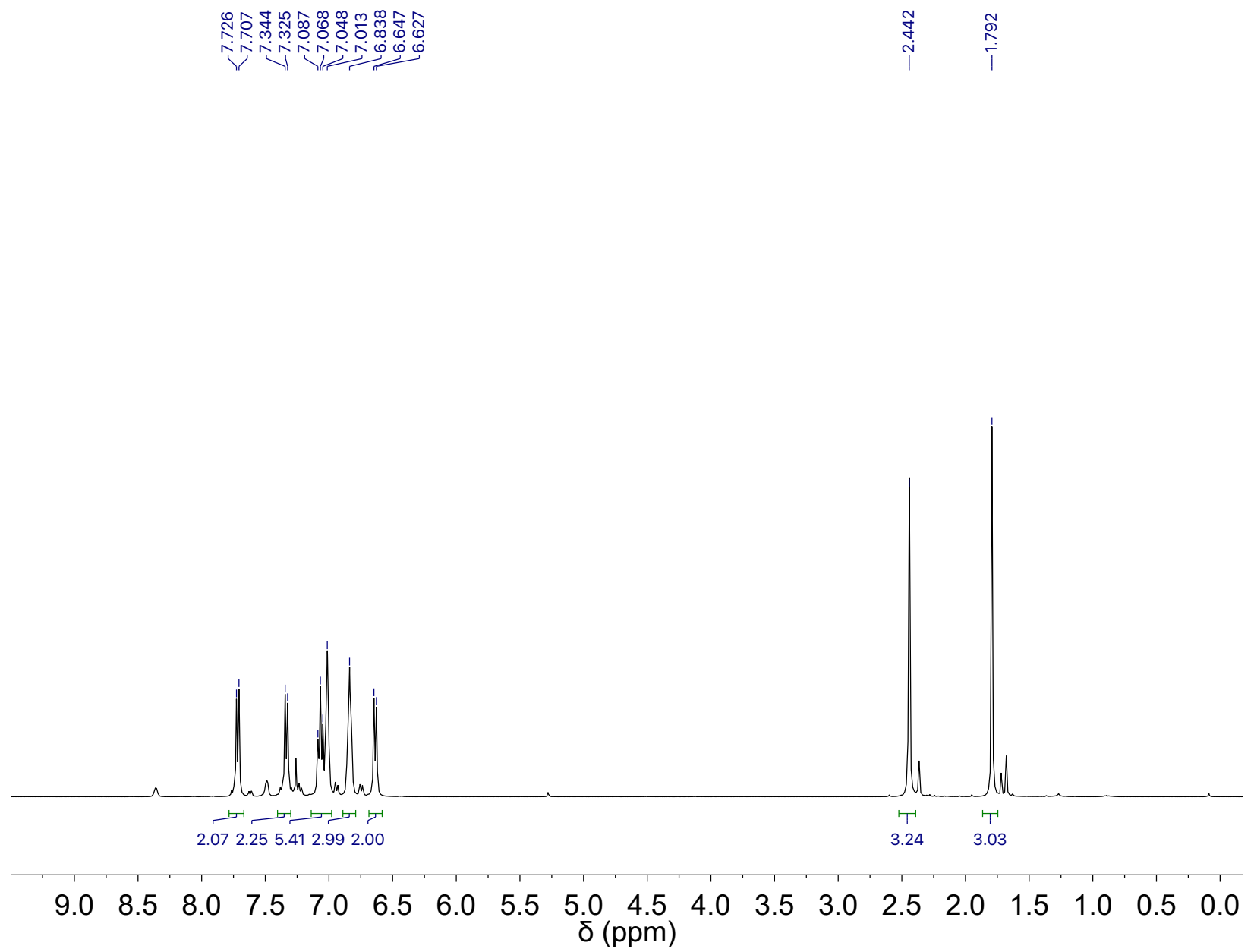

Figure S11. ${ }^{1} \mathrm{H}$ NMR spectrum of $8 \mathbf{a}$ in $\mathrm{CDCl}_{3}$. 

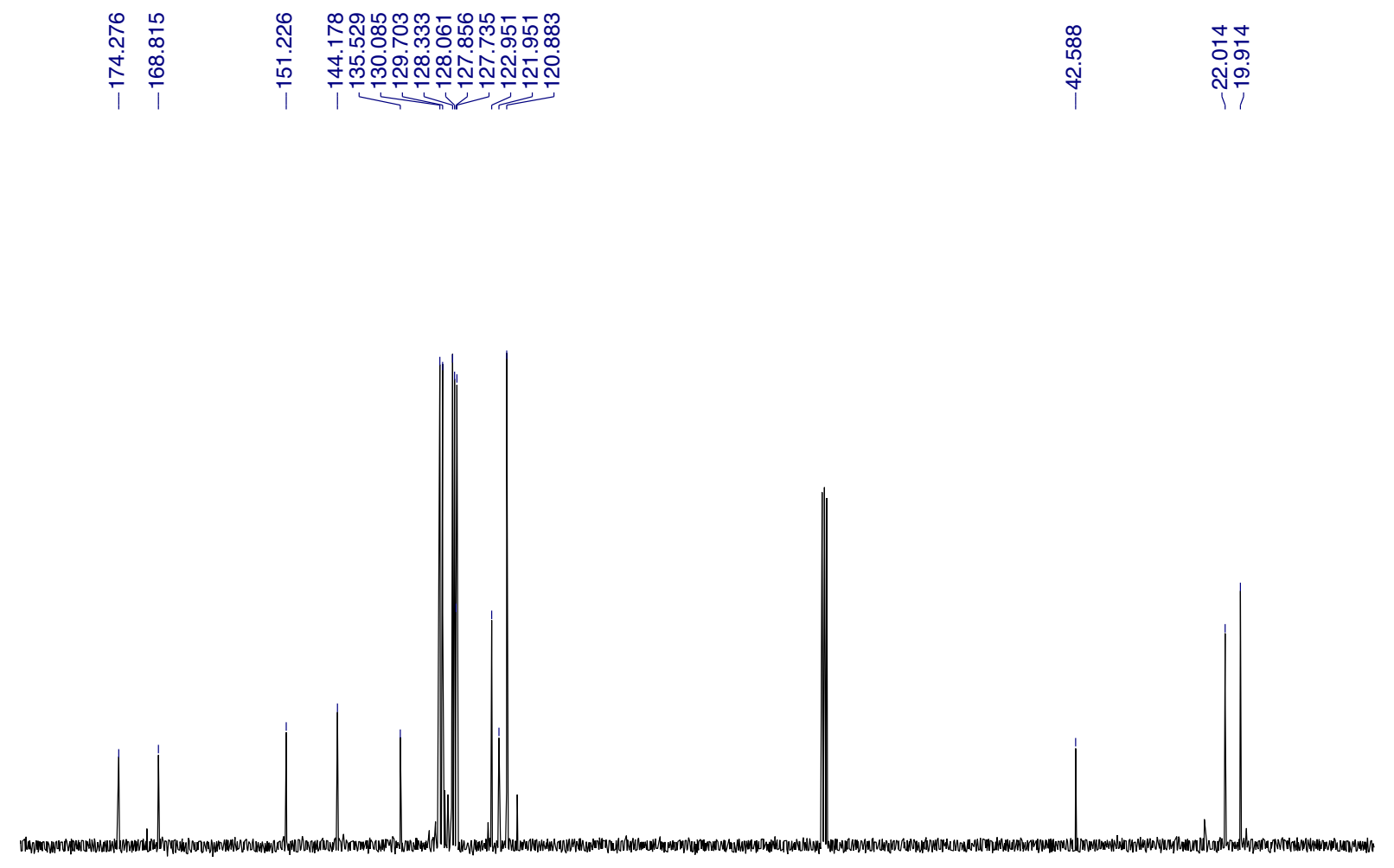

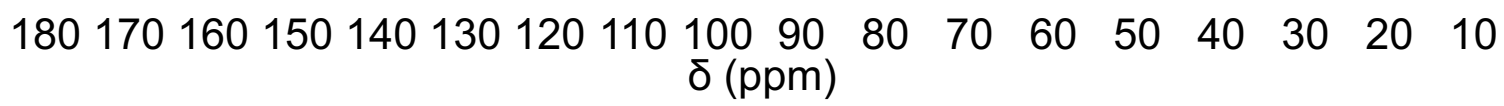

Figure $\mathrm{S} 12 .{ }^{13} \mathrm{C}$ NMR spectrum of $8 \mathrm{a}$ in $\mathrm{CDCl}_{3}$.

$C p_{2} \operatorname{Ti}\left(A^{2} A^{P h}\right)(9 a)$

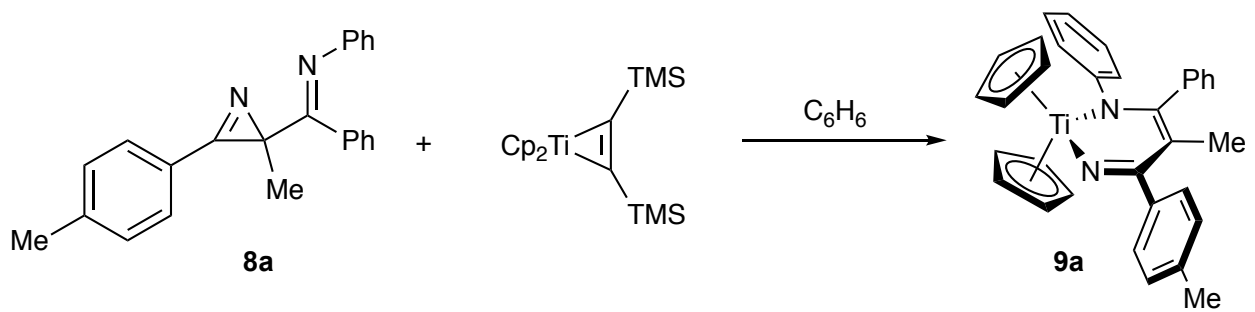

$8 \mathrm{a}$ (34.0 mg, $0.105 \mathrm{mmol}, 1$ equiv.) and $\mathrm{Cp}_{2} \mathrm{Ti}(\mathrm{BTMSA})(36.9 \mathrm{mg}, 0.106 \mathrm{mmol}, 1.01$ equiv.) were dissolved in benzene (approx. $1 \mathrm{~mL}$ each) in separate vials. The solution of $8 \mathbf{a}$ was added dropwise to the stirring solution of $\mathrm{Cp}_{2} \mathrm{Ti}(\mathrm{BTMSA})$, which turns bright red-violet immediately upon addition. The reaction was allowed to stir at room temperature for 15 minutes. The solvent was then removed under vacuum, and the residue washed with pentane to remove bis(trimethylsilyl)acetylene and any excess $\mathrm{Cp}_{2} \mathrm{Ti}(\mathrm{BTMSA})$, to give 9a (32 mg, 60.7\%). ${ }^{1} \mathrm{H}$ NMR $\left(500 \mathrm{MHz}, \mathrm{C}_{6} \mathrm{D}_{6}\right): \delta 7.49(\mathrm{~d}, 2 \mathrm{H}, \mathrm{Ar}-\mathrm{H}), 7.07(\mathrm{~d}$, $2 \mathrm{H}, \mathrm{Ar}-H), 6.96(\mathrm{~m}, 4 \mathrm{H}, \mathrm{Ar}-H), 6.87(\mathrm{t}, 2 \mathrm{H}, \mathrm{Ar}-\mathrm{H}), 6.79(\mathrm{~m}, 1 \mathrm{H}, \mathrm{Ar}-H), 6.74(\mathrm{~d}, 2 \mathrm{H}, \mathrm{Ar}-\mathrm{H}), 6.64(\mathrm{t}, 1 \mathrm{H}$, $\mathrm{Ar}-\mathrm{H}), 5.79$ (s, 10H, Cp-H), 2.14 (s, 3H, p-tolC $\left.H_{3}\right), 1.87$ (s, 3H, $\left.\left.\mathrm{CH}_{3}\right) .{ }^{13} \mathrm{C} \mathrm{NMR} \mathrm{(100} \mathrm{MHz,} \mathrm{C}_{6} \mathrm{D}_{6}\right): \delta$ 168.05, 167.86, 157.22, 142.93, 137.32, 137.14, 130.33, 129.12, 128.59, 128.43, 127.92, 126.56, 123.14, 113.57, 111.68, 106.03, 21.27, 20.17. Anal. Calcd. $\mathrm{C}_{33} \mathrm{H}_{30} \mathrm{~N}_{2} \mathrm{Ti}(\%): \mathrm{C}, 78.80 ; \mathrm{H}, 6.02 ; \mathrm{N}, 5.58$. Found: C, 79.07; H, 6.18; N, 6.23. 


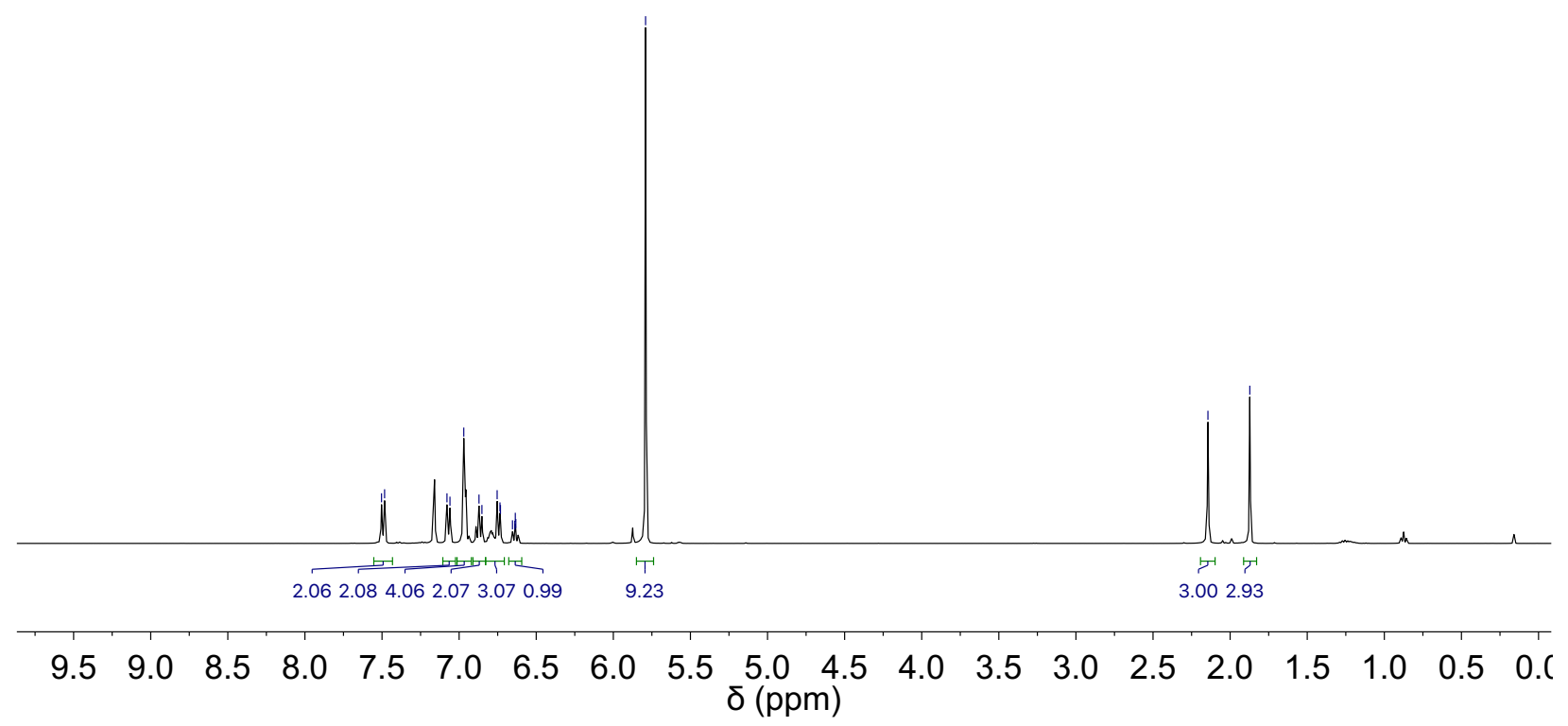

Figure S13. ${ }^{1} \mathrm{H}$ NMR spectrum of $9 a$ in $\mathrm{C}_{6} \mathrm{D}_{6}$. 


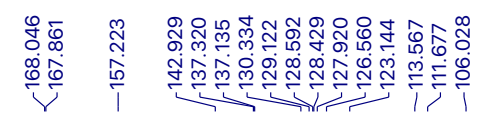

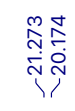

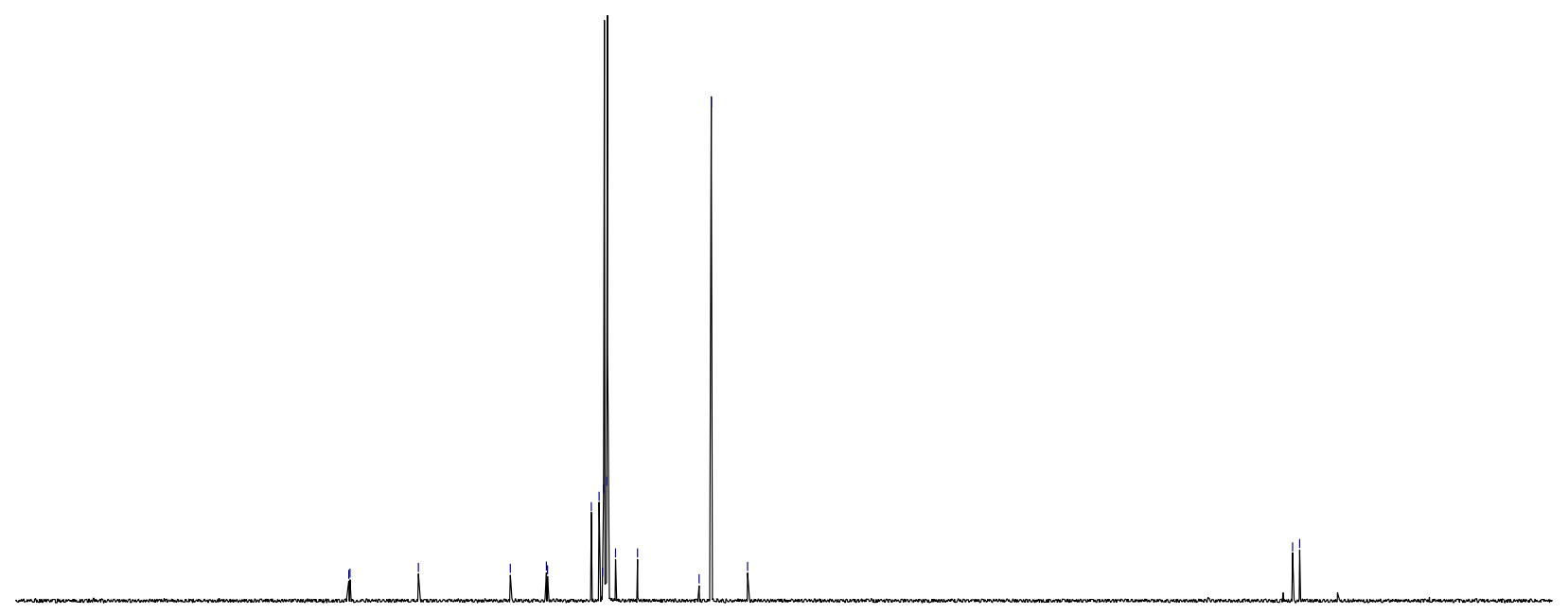

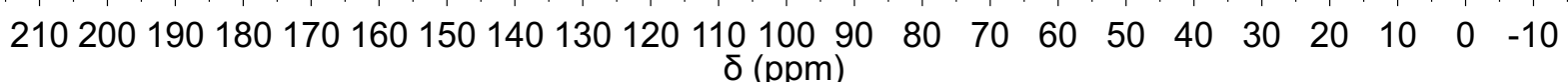

Figure S14. ${ }^{13} \mathrm{C}$ NMR spectrum of $9 a$ in $\mathrm{C}_{6} \mathrm{D}_{6}$.

\section{Reaction of $\mathrm{Cp}_{2} \mathrm{Ti}\left(\mathrm{ADA}^{\mathrm{Ph}}\right)(9 \mathrm{a})$ with $\mathrm{PhICl}_{2}$ (synthesis of $10 \mathrm{a}$ )}

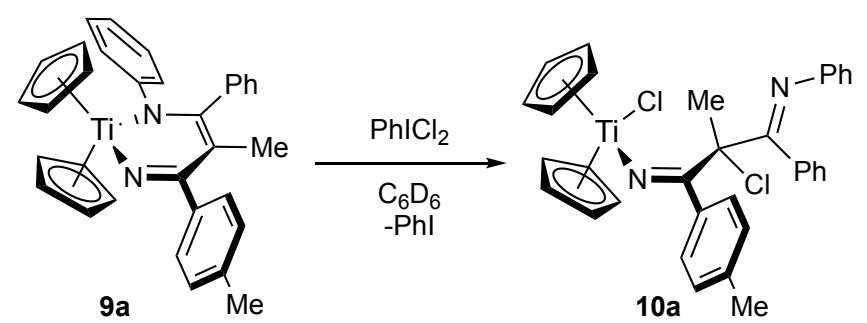

Procedure: 9a (14.3 mg, $0.0285 \mathrm{mmol}, 1$ equiv.) was weighed out in an NMR tube and dissolved in $\mathrm{C}_{6} \mathrm{D}_{6}$ (approximately $0.25 \mathrm{~mL}$ ). $\mathrm{PhICl}_{2}(8.0 \mathrm{mg}, 0.029 \mathrm{mmol}, 1.0$ equiv.) was massed out in a vial, and dissolved in $\mathrm{C}_{6} \mathrm{D}_{6}$ (approximately $0.25 \mathrm{~mL}$ ). The $\mathrm{PhICl}_{2}$ solution was transferred to the NMR tube containing $9 \mathrm{a}$, and upon mixing, the solution immediately turns bright yellow, yielding 10a. Crystals of $10 a$ were grown from a mixture of toluene/ $\mathrm{Et}_{2} \mathrm{O} /$ pentane. 

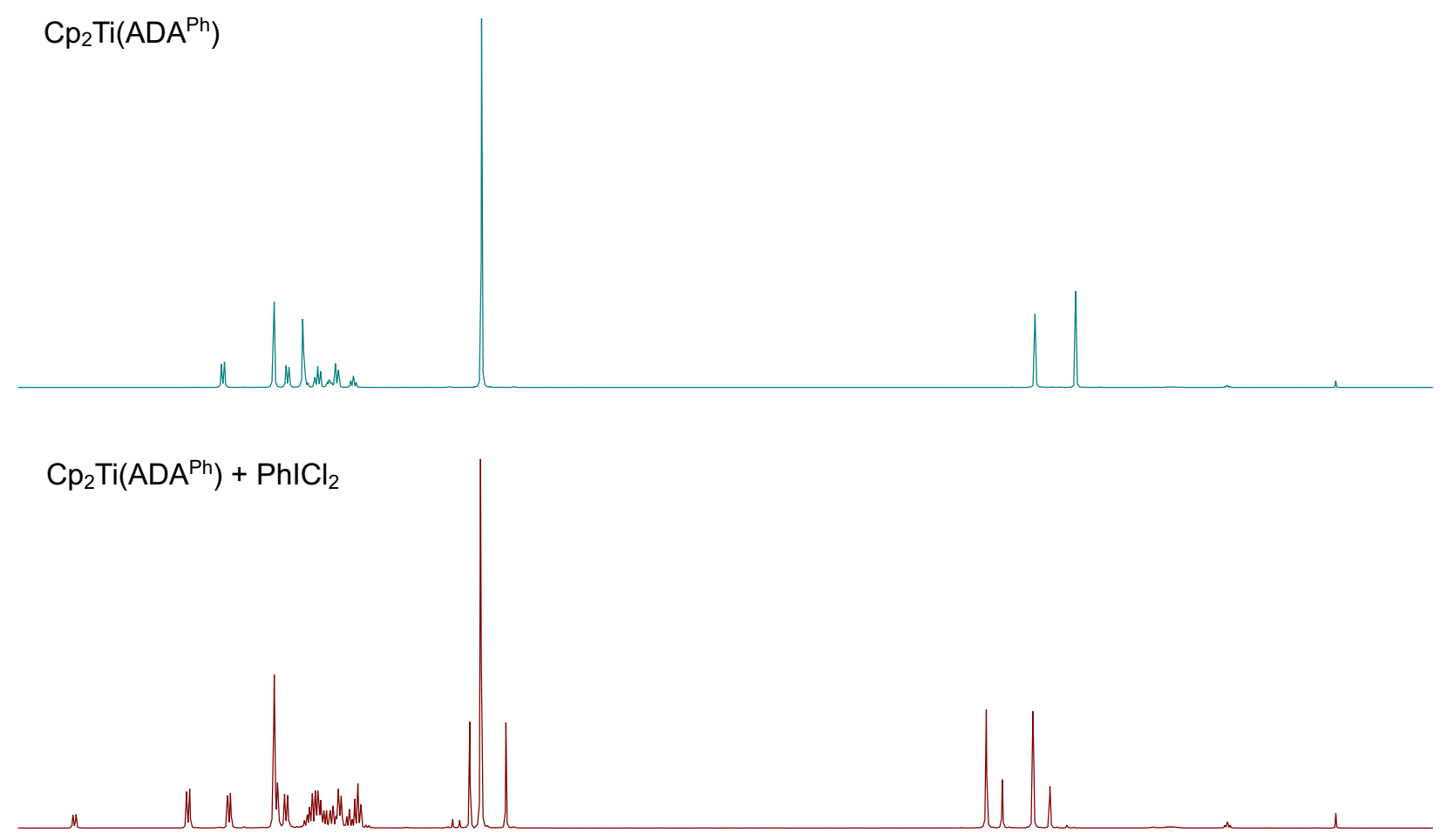

\section{$\begin{array}{llllllllllllllllll}8.5 & 8.0 & 7.5 & 7.0 & 6.5 & 6.0 & 5.5 & 5.0 & 4.5 & 4.0 & 3.5 & 3.0 & 2.5 & 2.0 & 1.5 & 1.0 & 0.5 & 0.0\end{array}$ $\delta(\mathrm{ppm})$}

Figure S15. Stacked ${ }^{1} \mathrm{H}$ NMR spectra characterizing the oxidation of $9 \mathrm{a}$ with $\mathrm{PhICl}_{2}$ to $10 \mathrm{a}$. Top (teal trace): ${ }^{1} \mathrm{H}$ NMR of $9 \mathrm{a}$. Bottom (red trace): ${ }^{1} \mathrm{H}$ NMR spectrum of oxidation of $9 \mathrm{a}$ with $\mathrm{PhICl}_{2}$ to $10 \mathrm{a}$.

\section{4,5-diethyl-N-phenyl-3-(p-tolyl)pyrazole (1)}<smiles>CC/C=C(/CC)[N+](=O)[O-]</smiles>

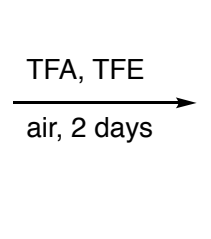<smiles>CCc1c(Cl)nn(-c2ccccc2)c1CC</smiles>

In a $20 \mathrm{~mL}$ scintillation vial was added 3-nitro-3-hexene (310 mg, $2.40 \mathrm{mmol}, 1.59$ equiv.), 1-(4methylbenzylidene)-2-phenylhydrazine (318 mg, $1.51 \mathrm{mmol}, 1$ equiv.), TFE (15 mL) and TFA (1.2 mL). The mixture was allowed to stir opened to air for 2 days (loosely capped to prevent splashing or particulate contamination). The volatiles were removed under vacuum, and the residue purified by column chromatography $\left(\mathrm{SiO}_{2}, 18 \%\right.$ EtOAc/Hexanes) to give $\mathbf{1}$ (138 mg, 31.5\% yield). ${ }^{1} \mathbf{H}$ NMR (500 $\mathrm{MHz}^{\mathrm{CDCl}} \mathrm{CDC}_{3}$ : $\delta 7.61$ (d, Ar-H, 2H), 7.45-7.51 (m, Ar-H, 4H), 7.39 (t, Ar-H, 1H), $7.23(\mathrm{~d}, \mathrm{Ar}-\mathrm{H}, 2 \mathrm{H})$, 2.72 (q, $\mathrm{CH}_{2} \mathrm{CH}_{3}, 2 \mathrm{H}$ ), 2.66 (q, $\mathrm{CH}_{2} \mathrm{CH}_{3}, 2 \mathrm{H}$ ), 2.39 (s, $\left.\mathrm{Ar}-\mathrm{CH}_{3}, 3 \mathrm{H}\right), 1.19$ (t, $\mathrm{CH}_{2} \mathrm{CH}_{3}, 3 \mathrm{H}$ ), 1.10 (t, $\left.\mathrm{CH}_{2} \mathrm{CH}_{3}, 3 \mathrm{H}\right) .{ }^{13} \mathrm{C}$ NMR (100 MHz, $\left.\mathrm{CDCl}_{3}\right): \delta$ 150.54, 142.82, 140.52, 137.14, 131.58, 129.19, 129.17, 
127.86, 127.82, 125.79, 118.56, 21.41, 18.01, 17.28, 15.93, 14.30. ESI-HRMS (m/z): calcd. for $\mathrm{C}_{20} \mathrm{H}-$ ${ }_{22} \mathrm{~N}_{2} \mathrm{Na}^{+}, 313.1681$; found, 313.1690.
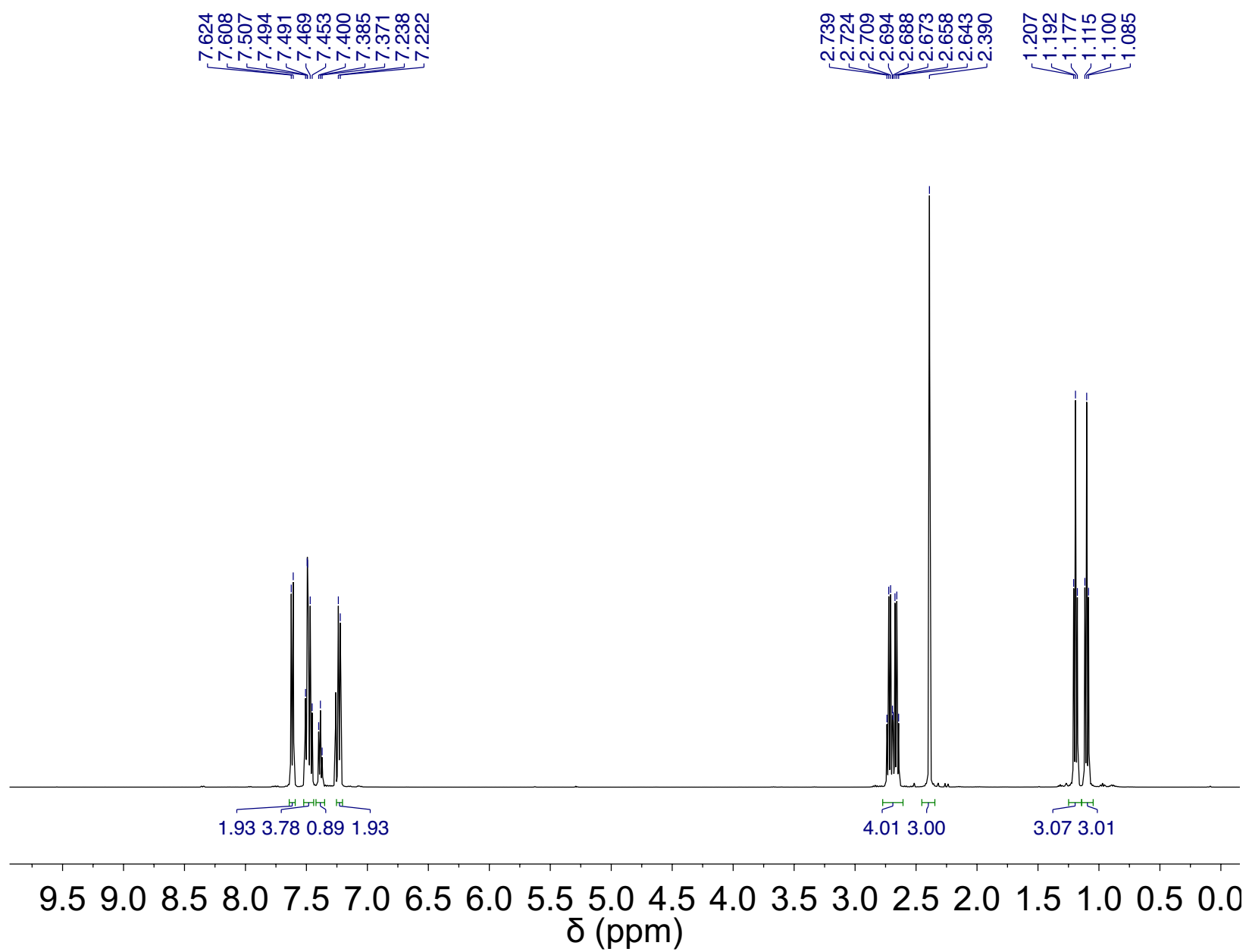

Figure S16. ${ }^{1} \mathrm{H}$ NMR spectrum of 1 in $\mathrm{CDCl}_{3}$. 

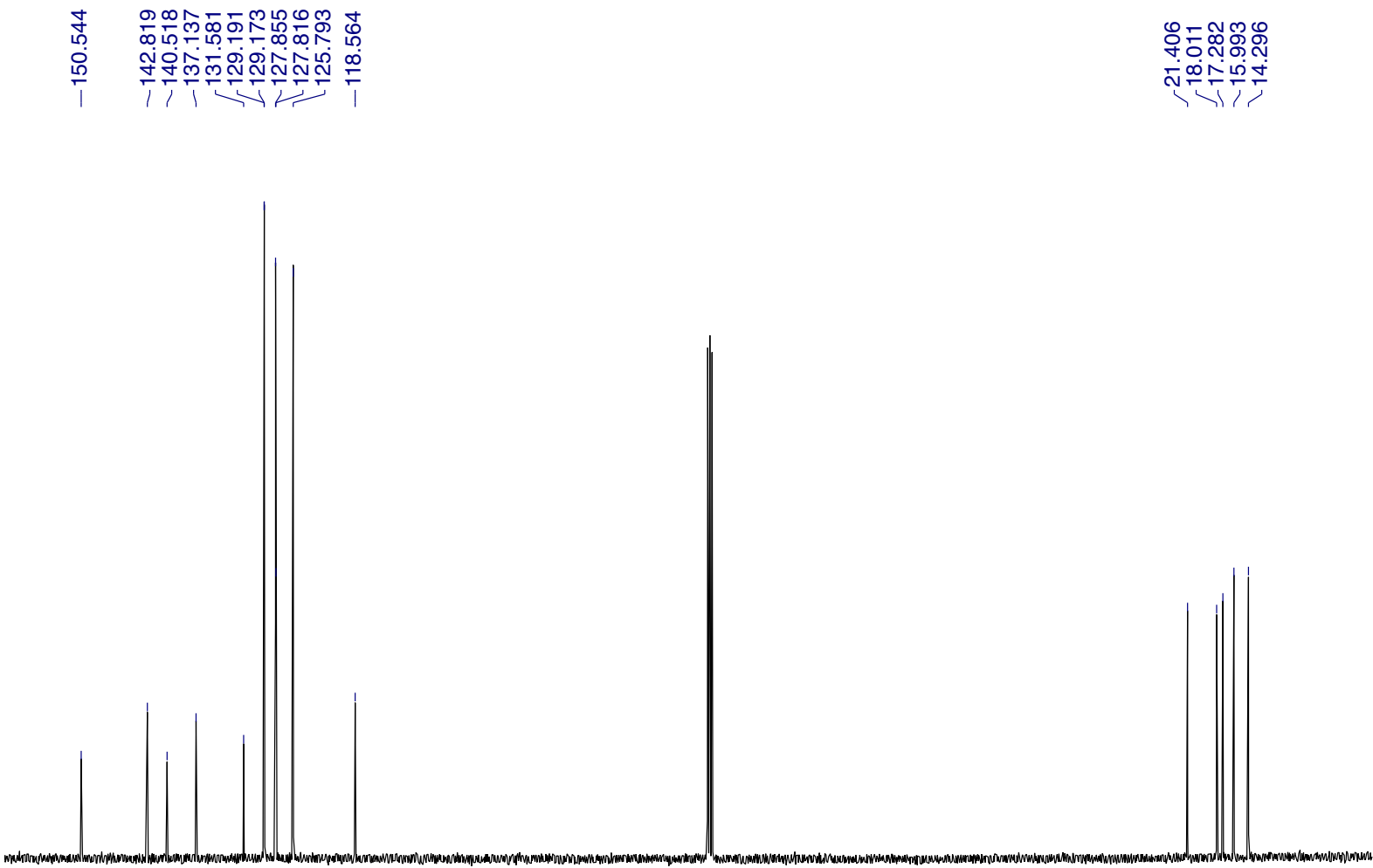

$\begin{array}{llllllllllllllll}150 & 140 & 130 & 120 & 110 & 100 & 90 & \underset{\delta(\mathrm{ppm})}{80} & 70 & 60 & 50 & 40 & 30 & 20 & 10 & C\end{array}$

Figure $\mathrm{S} 17 .{ }^{13} \mathrm{C}$ NMR spectrum of 1 in $\mathrm{CDCl}_{3}$.

\section{Diazatitanacyclohexadiene oxidations with TEMPO (Table 1, Entry 1)}

4-methyl-1,5-diphenyl-3-(p-tolyl)-1H-pyrazole (1a)<smiles>Cc1ccccc1</smiles>

$7 a$<smiles>Cc1c(Cl)nn(-c2ccccc2)c1-c1ccccc1</smiles>

$1 \mathrm{a}$

In a glovebox, 7a (60.0 mg, $0.0998 \mathrm{mmol}, 1$ equiv.) and TEMPO (32.5 mg, $0.208 \mathrm{mmol}, 2.08$ equiv.) was added to a scintillation vial along with a stir bar and $5 \mathrm{~mL}$ of benzene. The vial was sealed with a Teflon cap, removed from the glovebox, and heated to $50{ }^{\circ} \mathrm{C}$ for 2 hours with stirring. After the reaction was completed, the mixture was passed through a plug of silica, and the silica washed with DCM (approximately $2 \mathrm{~mL}$ ). The volatiles were removed in vacuo to obtain $1 \mathbf{1 a}\left(26 \mathrm{mg}, 80 \%\right.$ yield). ${ }^{1} \mathbf{H}$ NMR (500 MHz, $\left.\mathrm{C}_{6} \mathrm{D}_{6}\right)$ : $\delta 8.03$ (d, Ar-H, 2H), 7.41 (d, Ar-H, 2H), $7.18(\mathrm{~d}, \mathrm{Ar}-\mathrm{H}, 2 \mathrm{H})$, 6.99-7.08 (m, Ar- 
$H, 5 \mathrm{H}), 6.95(\mathrm{t}, \mathrm{Ar}-\mathrm{H}, 2 \mathrm{H}), 6.86(\mathrm{t}, \mathrm{Ar}-\mathrm{H}, 1 \mathrm{H}), 2.19\left(\mathrm{~s}, \mathrm{CH}_{3}, 3 \mathrm{H}\right), 2.18\left(\mathrm{~s}, \mathrm{CH}_{3}, 3 \mathrm{H}\right) .{ }^{1} \mathrm{H}$ NMR (500 MHz, $\left.\mathrm{CDCl}_{3}\right)$ : $\delta 7.72(\mathrm{~d}, \mathrm{Ar}-\mathrm{H}, 2 \mathrm{H}), 7.34-7.40(\mathrm{~m}, \mathrm{Ar}-\mathrm{H}, 3 \mathrm{H}), 7.19-7.32(\mathrm{~m}, \mathrm{Ar}-\mathrm{H}, 9 \mathrm{H}), 2.42\left(\mathrm{~s}, \mathrm{CH}_{3}, 3 \mathrm{H}\right)$, 2.25 (s, $\left.\mathrm{CH}_{3}, 3 \mathrm{H}\right) .{ }^{13} \mathrm{C}$ NMR (100 MHz, $\left.\mathbf{C D C l}_{3}\right): \delta 151.29,141.45,140.23,137.38,130.96,130.84$, 130.14, 129.20, 128.72, 128.52, 128.17, 127.84, 126.75, 124.81, 114.11, 21.37, 10.30. ESI-HRMS: calcd. for $\mathrm{C}_{23} \mathrm{H}_{20} \mathrm{~N}_{2} \mathrm{H}^{+}, 325.1692$; found, 325.1705.
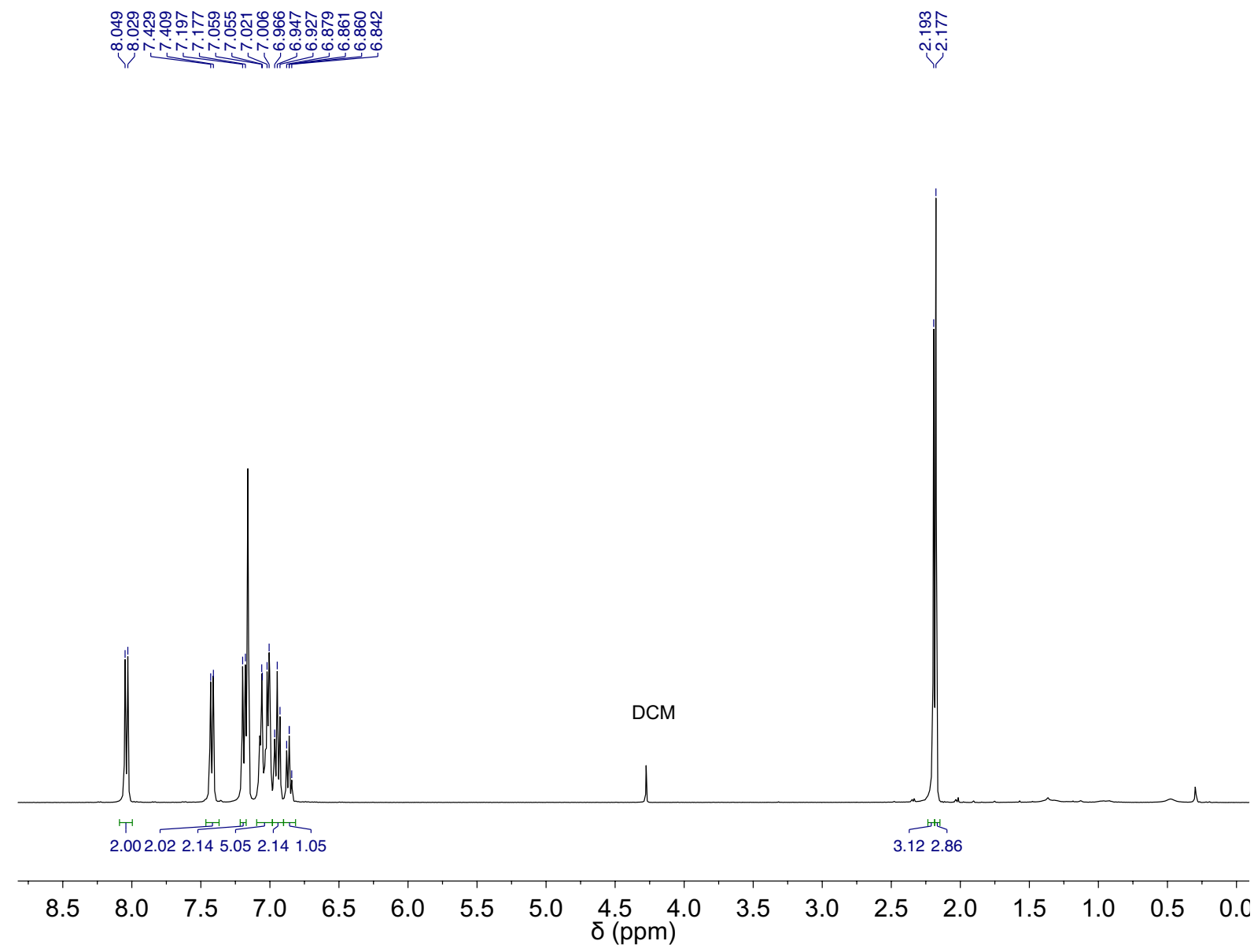

Figure S18. ${ }^{1} \mathrm{H}$ NMR spectrum of $1 \mathrm{a}$ in $\mathrm{C}_{6} \mathrm{D}_{6}$. 


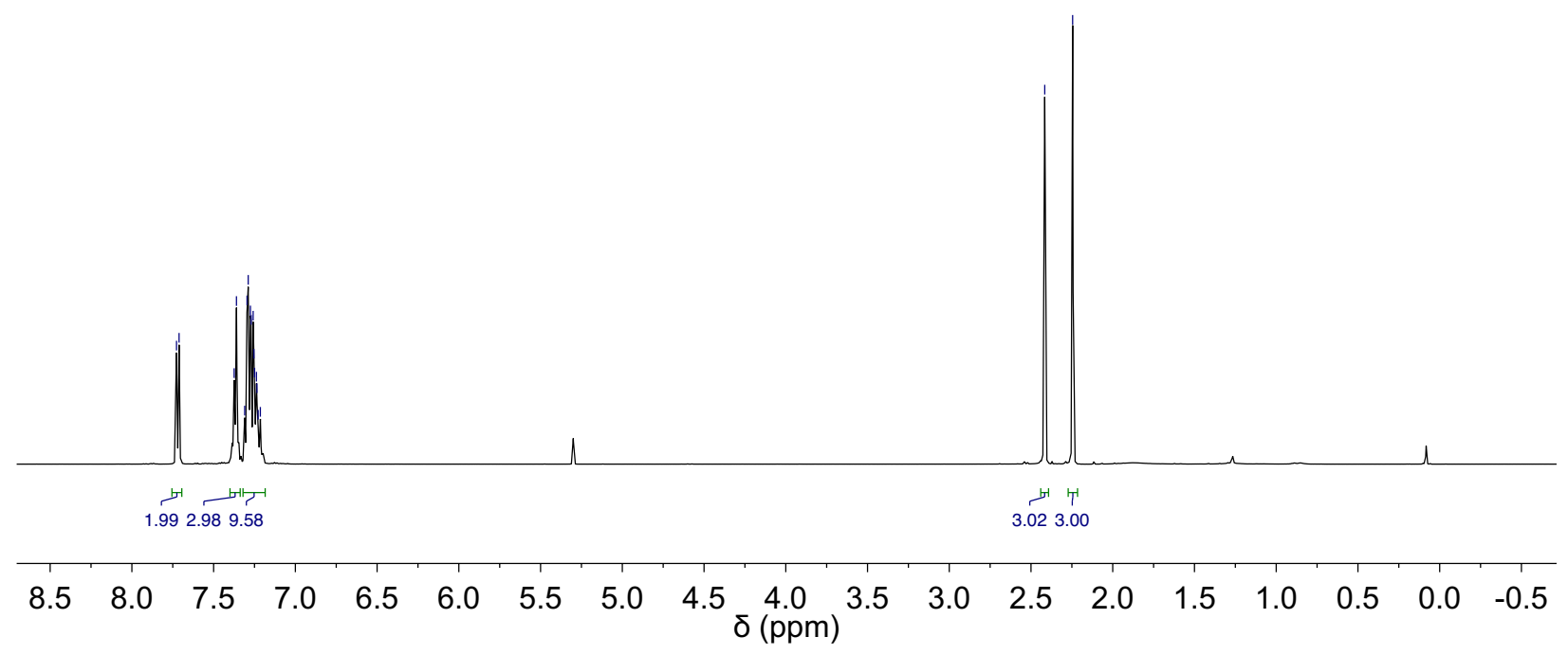

Figure S19. ${ }^{1} \mathrm{H}$ NMR spectrum of $1 \mathrm{a}$ in $\mathrm{CDCl}_{3}$. 


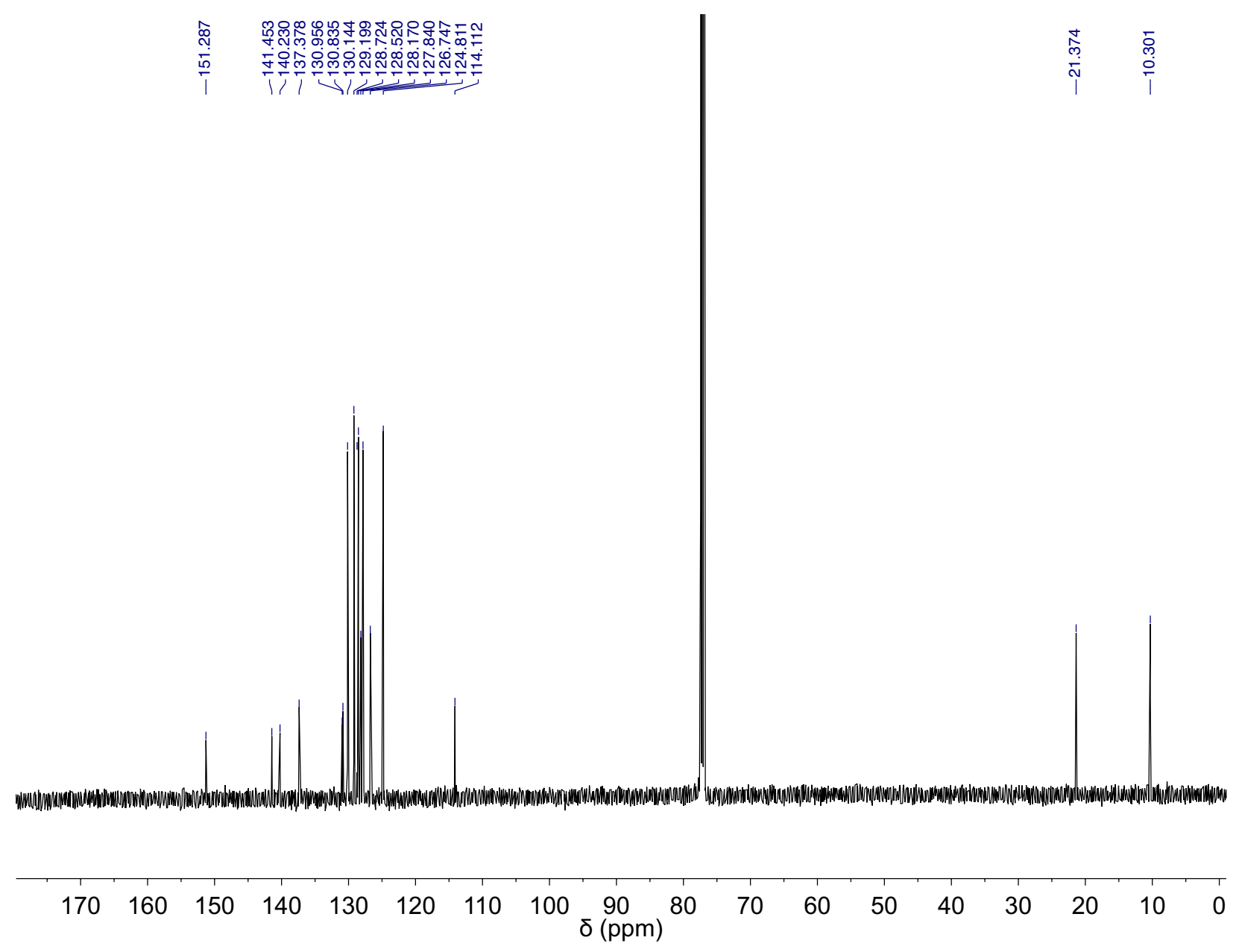

Figure S20. ${ }^{13} \mathrm{C}$ NMR spectrum of $1 \mathrm{a}$ in $\mathrm{CDCl}_{3}$.

\section{TEMPO oxidation of 7a (in situ, 2 equiv)}

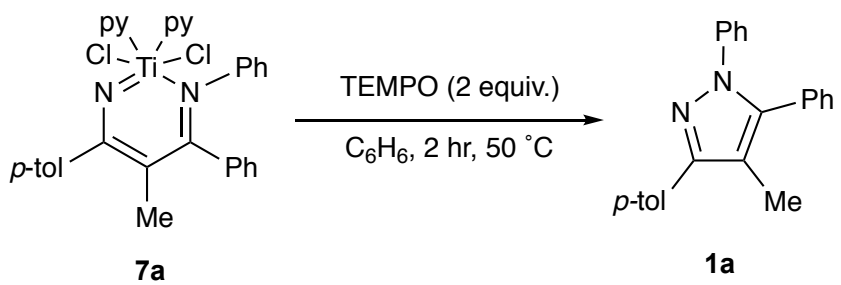

In situ Procedure: Diazatitanacyclohexadiene 7a $(6.1 \mathrm{mg}, 0.010 \mathrm{mmol}, 1$ equiv.) was dissolved in $0.5 \mathrm{~mL} \mathrm{C}_{6} \mathrm{D}_{6}$. TEMPO (3.7 mg, $0.024 \mathrm{mmol}, 2.4$ equiv.) was added, and a $\mathrm{t}=0{ }^{1} \mathrm{H}$ NMR was recorded. The mixture was allowed to heat for an hour, upon which another ${ }^{1} \mathrm{H}$ NMR was taken. The reaction was allowed to heat for another hour, and the final $\mathrm{t}=2 \mathrm{~h}$ time point ${ }^{1} \mathrm{H}$ NMR was taken. 


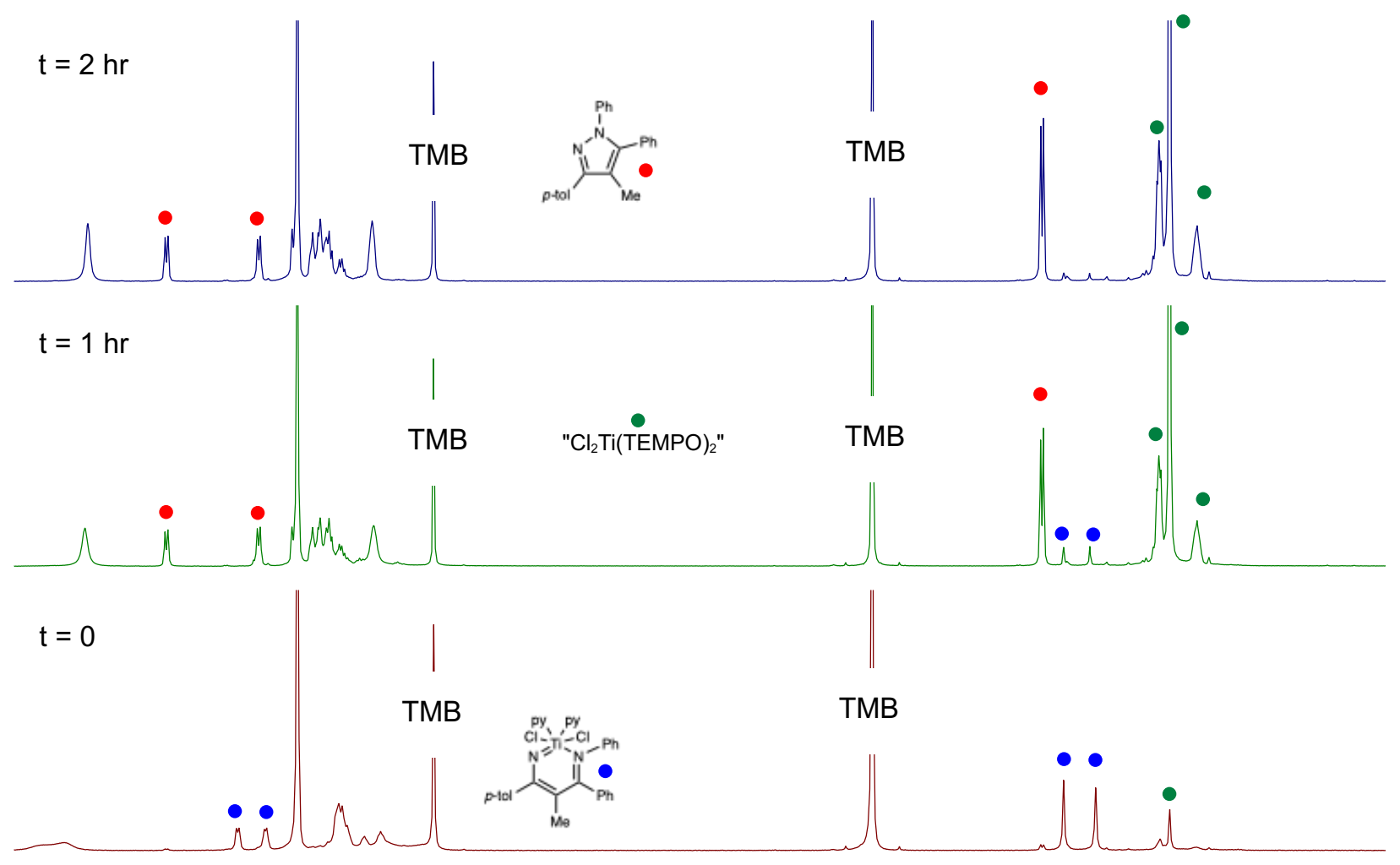

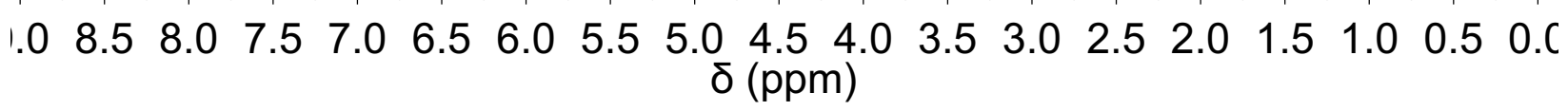

Figure S21. Stacked ${ }^{1} \mathrm{H}$ NMR spectra of in situ oxidation of $7 \mathrm{a}$ with TEMPO. Bottom (red trace): $\mathrm{t}=0$ immediately after the mixing of $7 a$ with TEMPO in $\mathrm{C}_{6} \mathrm{D}_{6}$. Middle (green trace): $\mathrm{t}=1 \mathrm{~h}$ at $50{ }^{\circ} \mathrm{C}$, showing the majority conversion of $7 \mathrm{a}$ to $1 \mathrm{a}$. Top (blue trace): $\mathrm{t}=2 \mathrm{~h}$ at $50{ }^{\circ} \mathrm{C}$, showing $>95 \%$ conversion to $1 \mathrm{a}$.

\section{TEMPO oxidation of 7 a (in situ, 1 equiv) (Table 1, entry 2)}

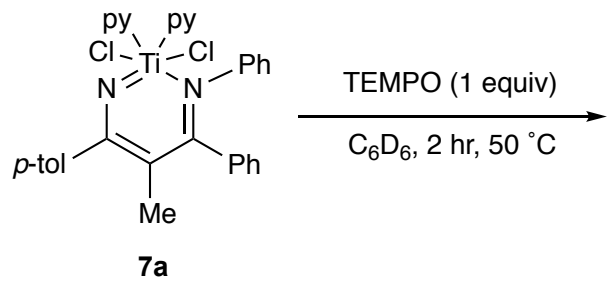<smiles>O=[N+]([O-])c1c(Cl)nn(-c2ccccc2)c1-c1ccccc1</smiles>

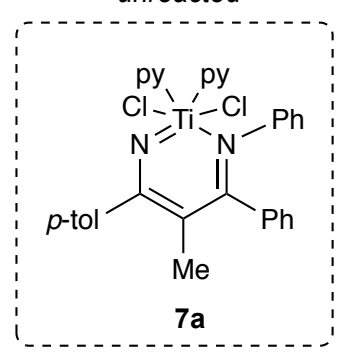

$1: 1$ molar ratio

Procedure: Diazatitanacyclohexadiene $7 \mathrm{a}(6.7 \mathrm{mg}, 0.011 \mathrm{mmol}, 1$ equiv) was dissolved in 0.5 $\mathrm{mL} \mathrm{C}_{6} \mathrm{D}_{6}$. TEMPO (1.7 mg, $0.011 \mathrm{mmol}, 1.0$ equiv) was added to a scintillation vial, dissolved in minimal $\mathrm{C}_{6} \mathrm{D}_{6}(\sim 0.3 \mathrm{~mL})$, and transferred via pipette to the solution of $7 \mathrm{a}$ in the NMR tube, and a $\mathrm{t}=0$ ${ }^{1} \mathrm{H}$ NMR was recorded. The mixture was allowed to heat for 2 hours, and the final $\mathrm{t}=2 \mathrm{~h}$ time point ${ }^{1} \mathrm{H}$ NMR was taken. 


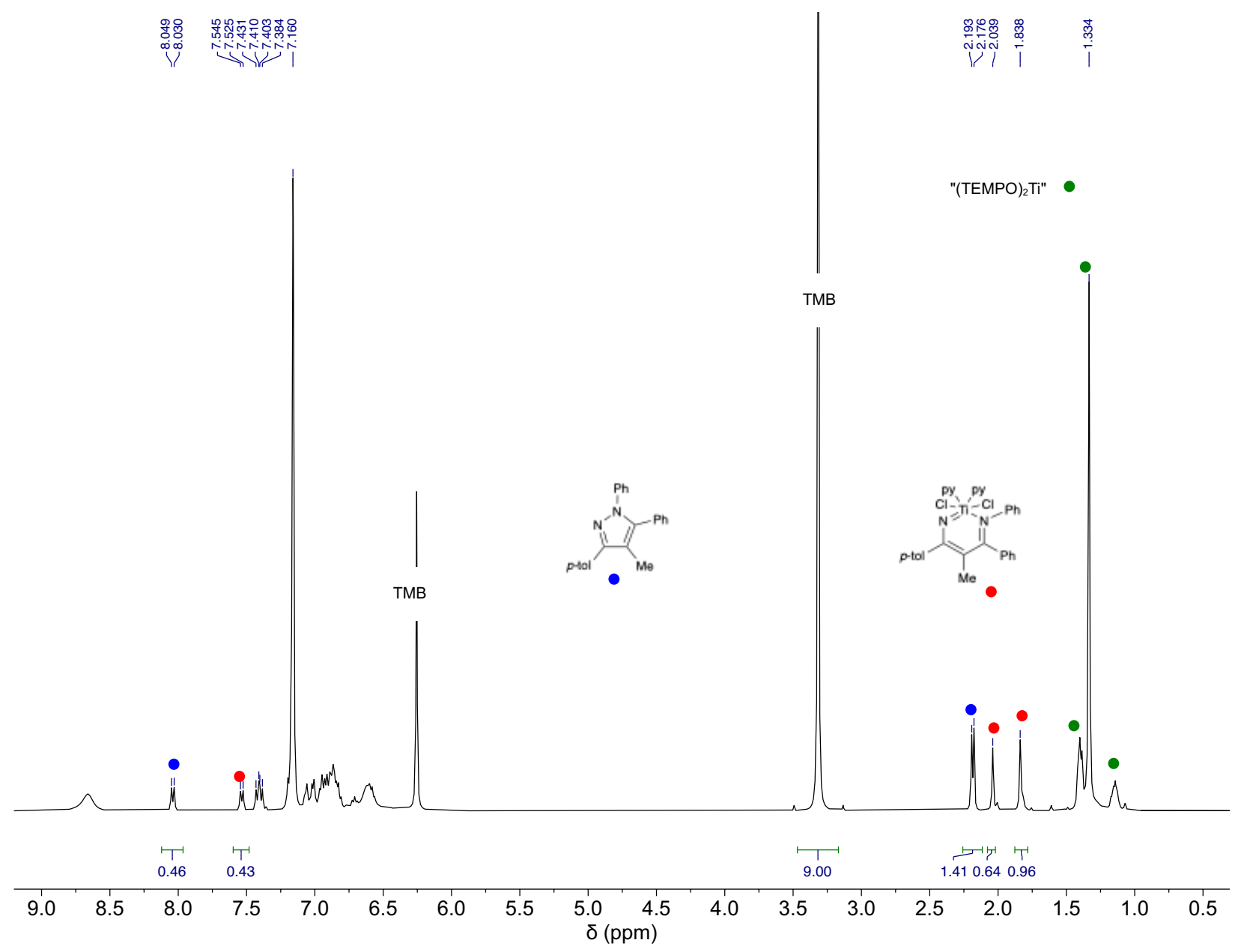

Figure S22. ${ }^{1} \mathrm{H}$ NMR spectrum $(\mathrm{t}=2 \mathrm{~h})$ showing the in situ oxidation of $7 \mathrm{a}$ with 1 equiv TEMPO.

\section{Hypervalent lodine Oxidations}

General Procedure: Diazatitanacyclohexadiene 7a-b $(0.01 \mathrm{mmol})$ was dissolved in $0.5 \mathrm{~mL} \mathrm{C}_{6} \mathrm{D}_{6}$ with stirring (Note: Crystalline 7a-b exhibit low solubility in benzene. Oxidations carried out with incomplete dissolution of $\mathbf{7 a - b}$ results in poor yields and complicated mixtures). These solutions were added to $0.01 \mathrm{mmol}$ of oxidant massed out in an NMR tube. The tubes were capped and inverted to mix. The reactions were allowed to stand for 3 hours, upon which time TCE standard $(6.0 \mu \mathrm{L}, 0.057$ $\mathrm{mmol}$ ) was added via syringe. Yields were taken by ${ }^{1} \mathrm{H}$ NMR against TCE standard. 


\section{$\mathrm{PhICl}_{2}$ oxidation (Table 1, Entry 3)}

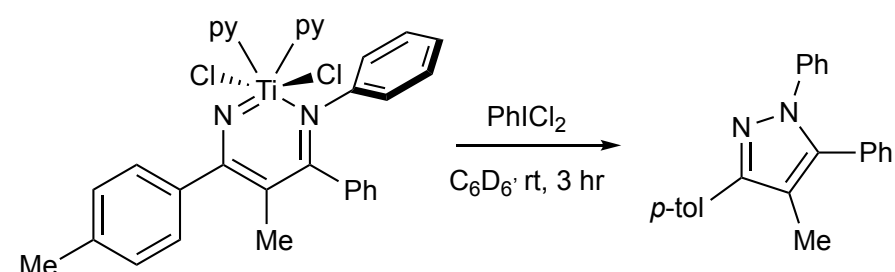

$7 a$

1a

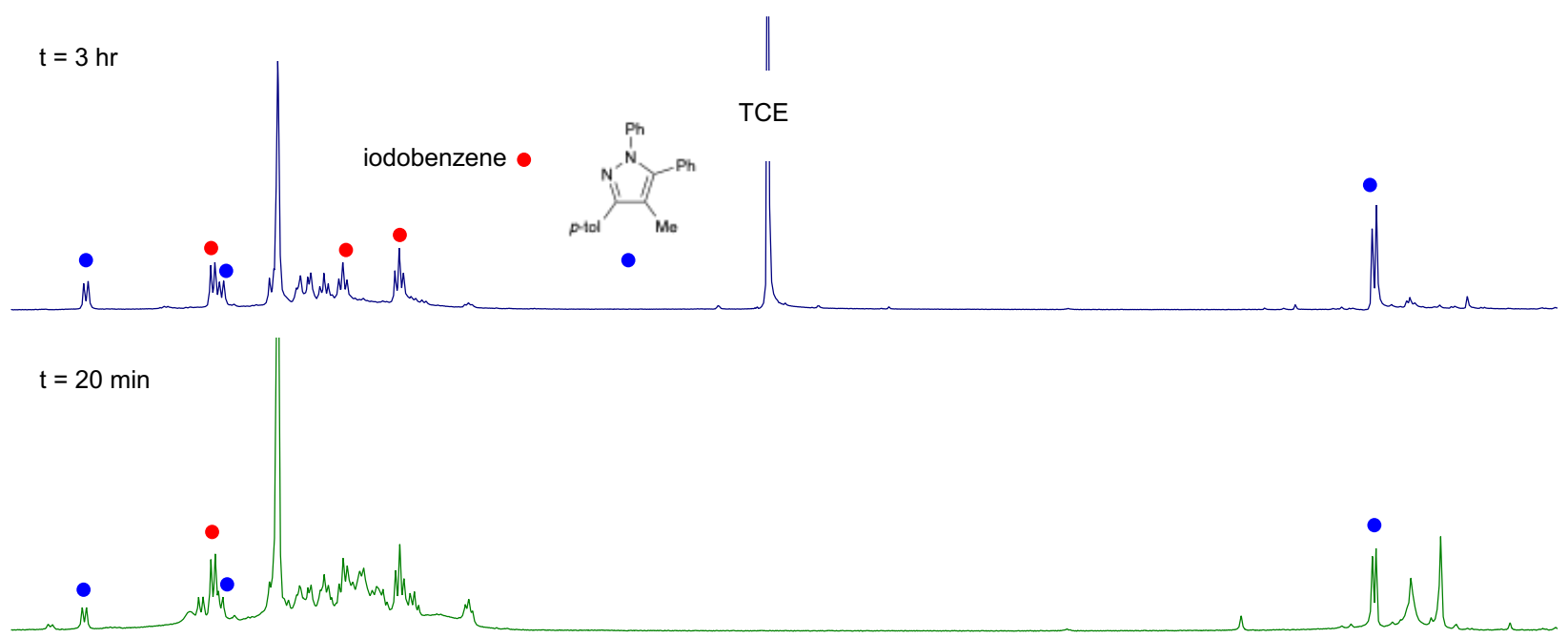

$7 a$

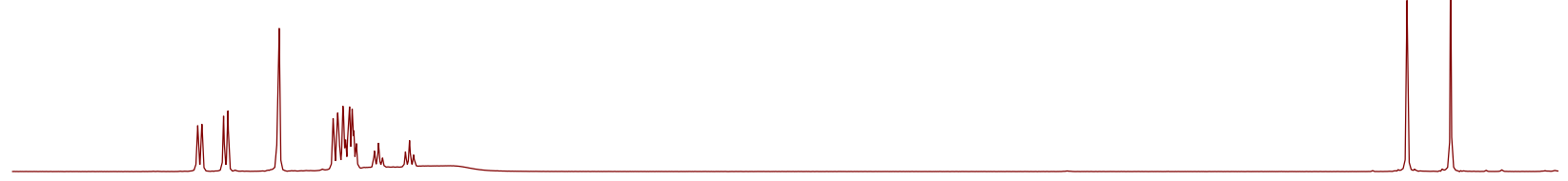

\section{$\begin{array}{llllllllllllll}8.0 & 7.5 & 7.0 & 6.5 & 6.0 & 5.5 & \underset{\delta}{5.0}(\mathrm{ppm}) & 4.5 & 4.0 & 3.5 & 3.0 & 2.5 & 2.0 & 1.5\end{array}$}

Figure S23. Stacked ${ }^{1} \mathrm{H}$ NMR spectra characterizing the oxidation of 7 a with $\mathrm{PhICl}_{2}$ in $\mathrm{C}_{6} \mathrm{D}_{6}$. Bottom (red trace): Clean spectrum of $7 a$ in $\mathrm{C}_{6} \mathrm{D}_{6}$ (for comparison). Middle (green trace): $\mathrm{t}=20 \mathrm{~min}$. after mixing $7 \mathrm{a}$ with $\mathrm{PhICl}_{2}$. Top (blue trace): $\mathrm{t}=3 \mathrm{~h}$. 


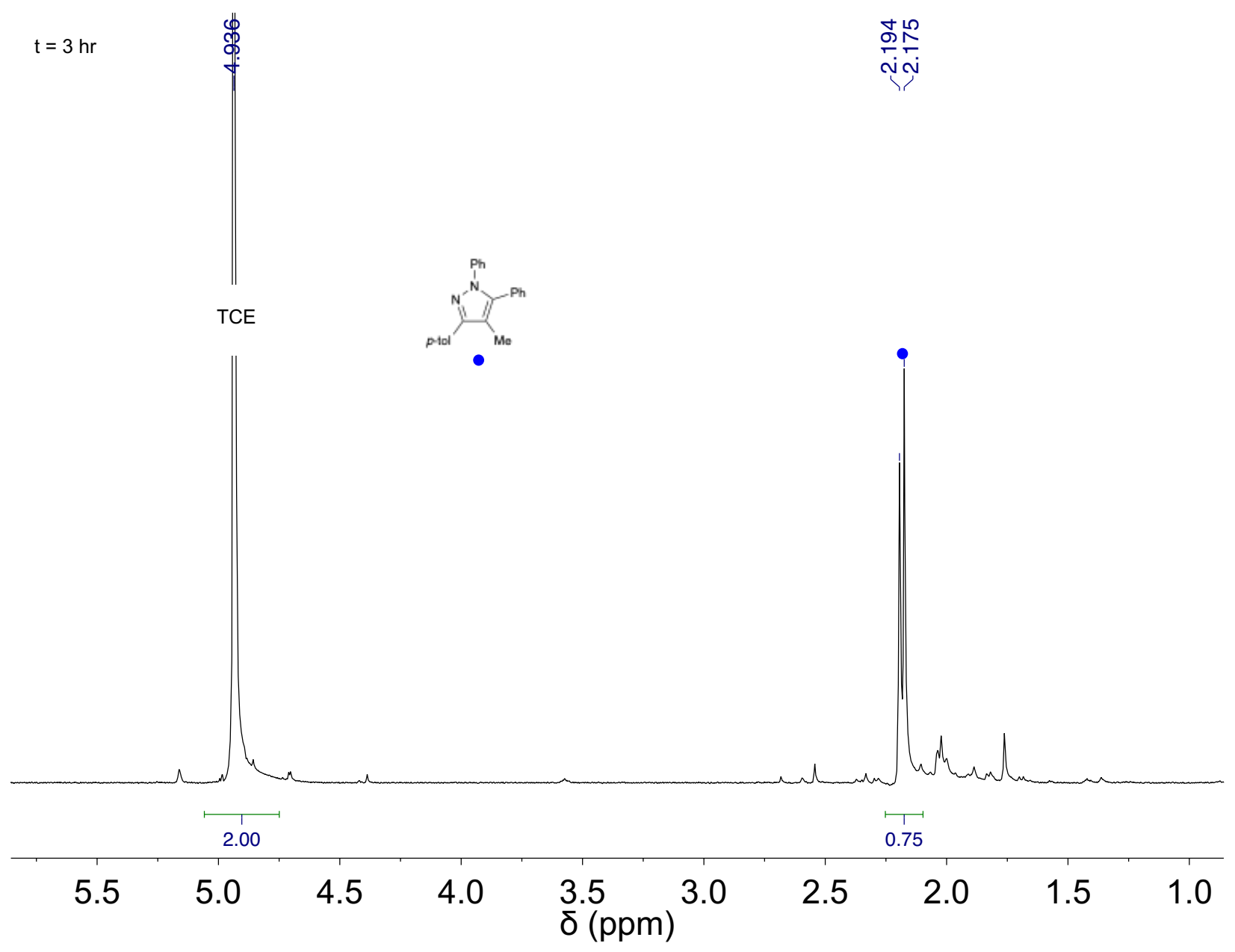

Figure S24. $\mathrm{t}=3 \mathrm{~h}^{1} \mathrm{H}$ NMR spectrum of the $\mathrm{PhICl}_{2}$ oxidation of $7 \mathrm{a}$ in $\mathrm{C}_{6} \mathrm{D}_{6}$. 
Phl(TFA) 2 oxidation (Table 1, Entry 4)<smiles>COC(=O)c1nc(-c2ccc(C)cc2)c(C)c(-c2ccccc2)c1-c1ccccc1</smiles>

$7 \mathrm{a}$

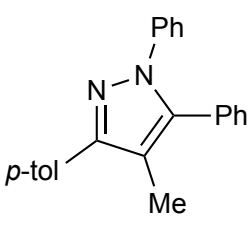

$1 \mathbf{a}$

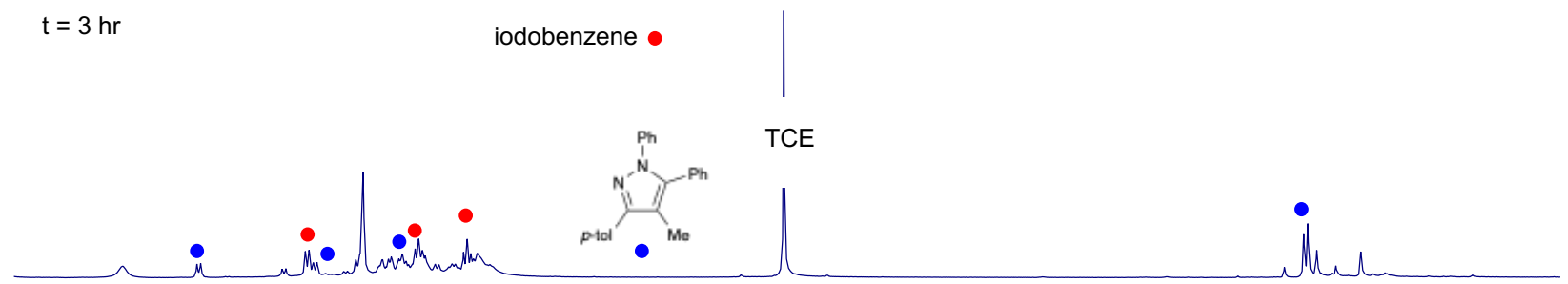

$t=20 \min$

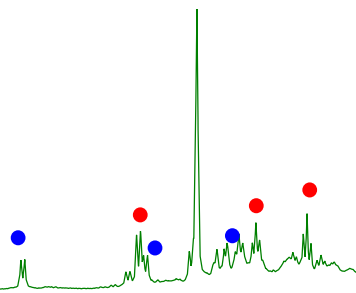

$7 a$

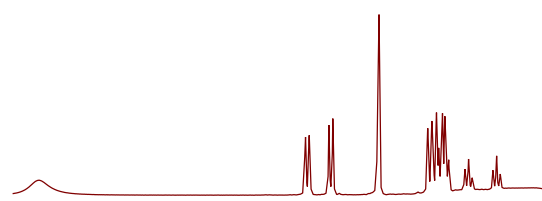

$\begin{array}{lllllllllllllllll}.0 & 8.5 & 8.0 & 7.5 & 7.0 & 6.5 & 6.0 & 5.5 & 5.0 & 4.5 & 4.0 & 3.5 & 3.0 & 2.5 & 2.0 & 1.5 & 1.0\end{array}$ $\delta(\mathrm{ppm})$

Figure S25. Stacked ${ }^{1} \mathrm{H}$ NMR spectra characterizing the oxidation of 7 a with $\mathrm{Phl}(\mathrm{TFA})_{2}$ in $\mathrm{C}_{6} \mathrm{D}_{6}$. Bottom (red trace): Clean spectrum of $7 \mathrm{a}$ in $\mathrm{C}_{6} \mathrm{D}_{6}$ (for comparison). Middle (green trace): $\mathrm{t}=20 \mathrm{~min}$. after mixing $7 \mathrm{a}$ with $\mathrm{PhI}(\mathrm{TFA})_{2}$. Top (blue trace): $\mathrm{t}=3 \mathrm{~h}$. 


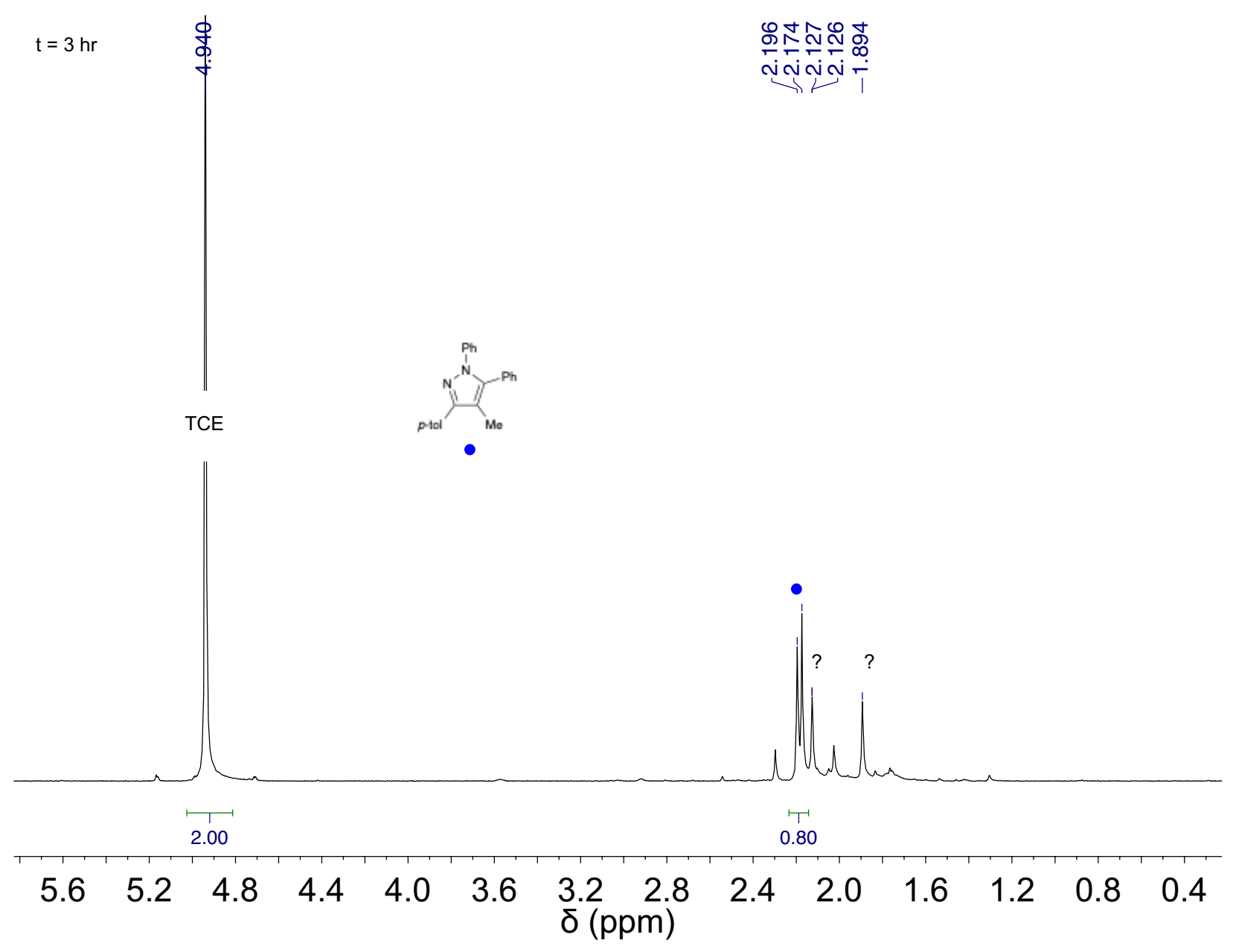

Figure S26. $t=3 \mathrm{~h}^{1} \mathrm{H}$ NMR spectrum of the $\mathrm{Phl}(\mathrm{TFA})_{2}$ oxidation of $7 \mathrm{a}$ in $\mathrm{C}_{6} \mathrm{D}_{6}$.

$\mathrm{Phl}(\mathrm{OAc})_{2}$ oxidation (Table 1, Entry 5)

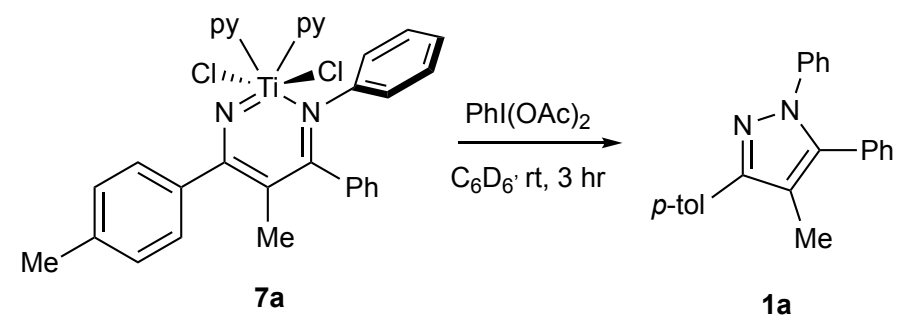




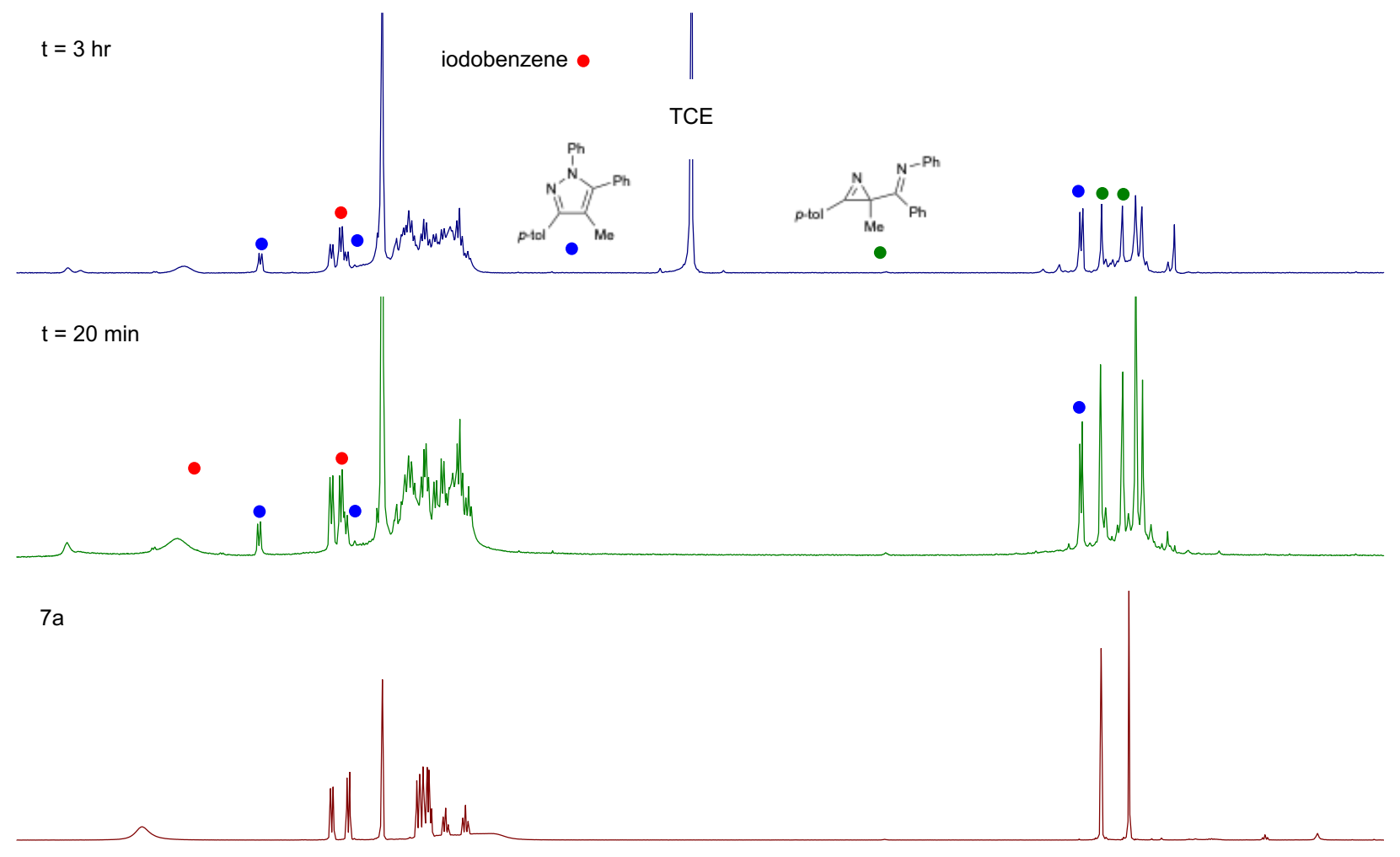

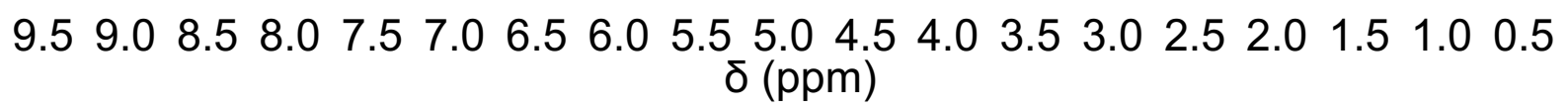

Figure S27. Stacked ${ }^{1} \mathrm{H}$ NMR spectra characterizing the oxidation of $7 a$ with $\mathrm{Phl}(\mathrm{OAc})_{2}$ in $\mathrm{C}_{6} \mathrm{D}_{6}$. Bottom (red trace): Clean spectrum of $7 \mathrm{a}$ in $\mathrm{C}_{6} \mathrm{D}_{6}$ (for comparison). Middle (green trace): $\mathrm{t}=20 \mathrm{~min}$. after mixing $7 \mathrm{a}$ with $\mathrm{Phl}(\mathrm{OAc})_{2}$. Top (blue trace): $\mathrm{t}=3 \mathrm{~h}$. 


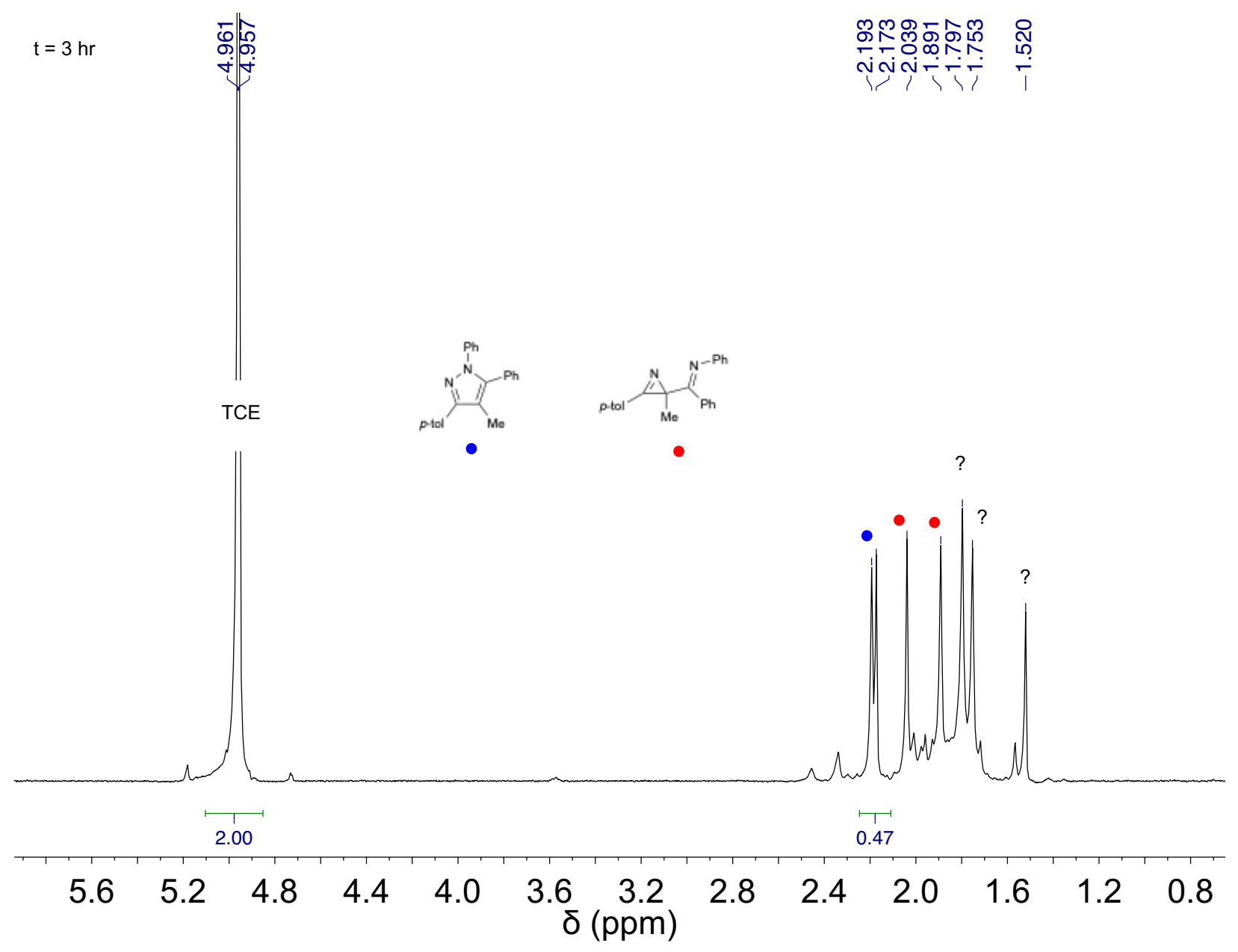

Figure S28. $\mathrm{t}=3 \mathrm{~h}{ }^{1} \mathrm{H}$ NMR spectrum of the $\mathrm{Phl}(\mathrm{OAc})_{2}$ oxidation of $7 \mathrm{a}$ in $\mathrm{C}_{6} \mathrm{D}_{6}$. 
Oxidation of $7 \mathrm{a}$ with ferrocenium hexafluorophosphate $(16 \mathrm{~h})$ (Table 1, Entry 6)

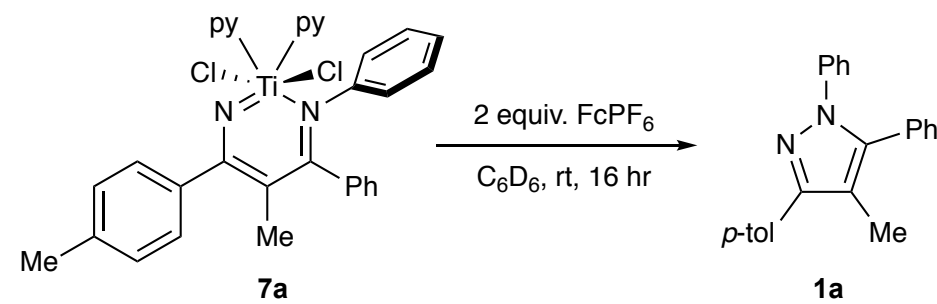

7a (12.1 mg, $0.0201 \mathrm{mmol}, 1$ equiv.) was dissolved in $0.5 \mathrm{~mL}$ of $\mathrm{C}_{6} \mathrm{D}_{6}$ in a $4 \mathrm{~mL}$ vial. To this was added $\mathrm{FcPF}_{6}$ (13.4 mg, 0.0405 mmol, 2.01 equiv.), which creates a dark suspension. This mixture was stirred overnight, then the mixture was decanted into an NMR tube along with the addition of 1,1,2,2tetrachloroethane $(4.0 \mu \mathrm{L}, 0.038 \mathrm{mmol})$ and its ${ }^{1} \mathrm{H}$ NMR spectrum recorded.

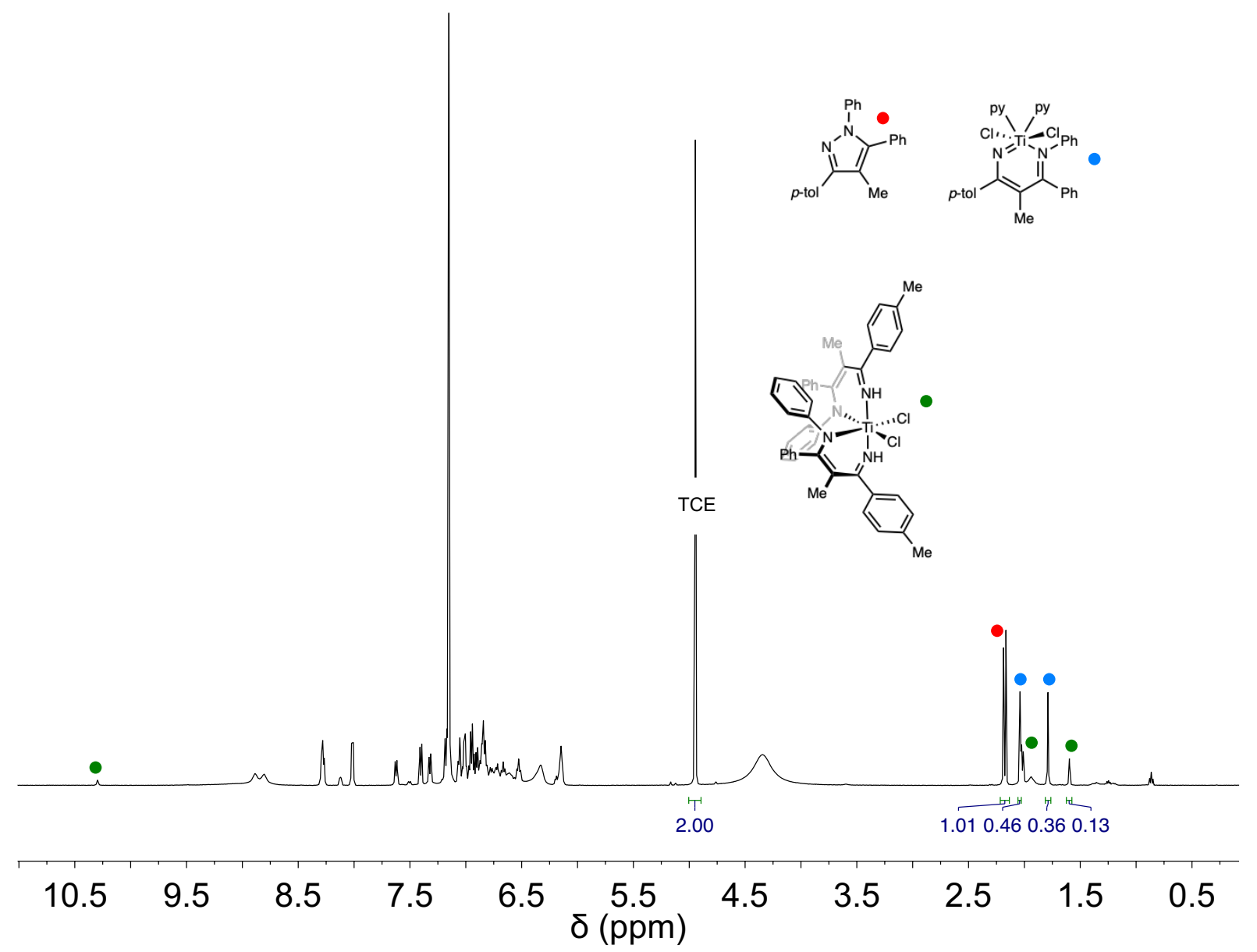

Figure S29. ${ }^{1} \mathrm{H}$ NMR spectrum of the oxidation of 7 a with $\mathrm{F}_{\mathrm{CPF}}$ for 16 hours in $\mathrm{C}_{6} \mathrm{D}_{6}$. 
Oxidation of $7 \mathrm{a}$ with ferrocenium hexafluorophosphate $(70 \mathrm{~h})$ (Table 1, Entry 7)

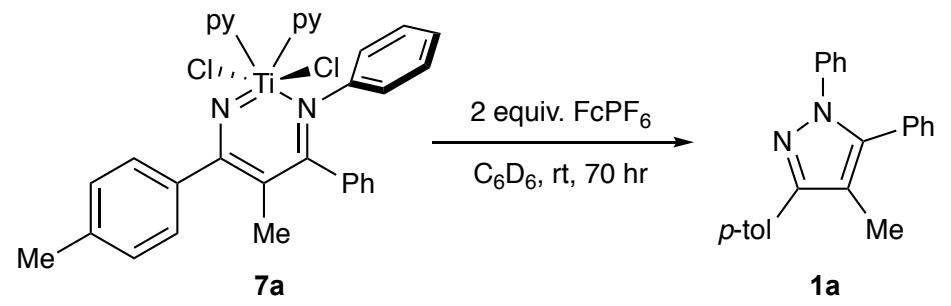

$7 a$ (8 mg, $0.013 \mathrm{mmol}, 1$ equiv.) was dissolved in $0.5 \mathrm{~mL}$ of $\mathrm{C}_{6} \mathrm{H}_{6}$ in a $4 \mathrm{~mL}$ vial. To this was added $\mathrm{FCPF}_{6}(12 \mathrm{mg}, 0.036 \mathrm{mmol}, 2.8$ equiv.), which creates a dark suspension. This mixture was stirred over three nights. After stirring, the mixture was decanted into an NMR tube, and its ${ }^{1} \mathrm{H}$ NMR spectrum recorded.

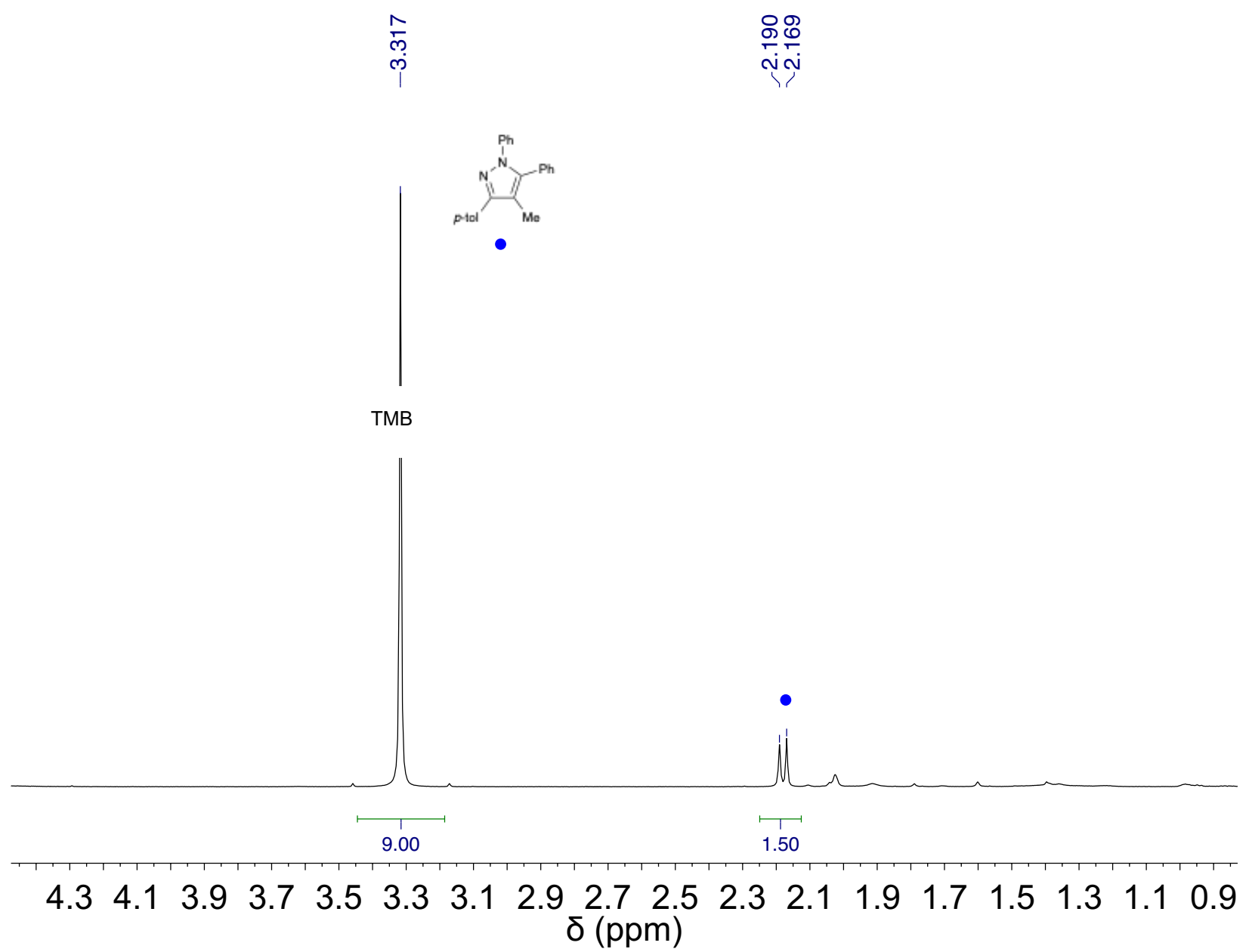

Figure S30. ${ }^{1} \mathrm{H}$ NMR spectrum of the oxidation of $7 \mathrm{a}$ with $\mathrm{FCPF}_{6}$ for 70 hours in $\mathrm{C}_{6} \mathrm{H}_{6}$. 


\section{Oxidation of 7 a with $\mathrm{O}_{2}$ (Table 1, Entry 8)}<smiles></smiles>

Procedure: To a J-Young tube was added 7a $(10.0 \mathrm{mg}, 0.0181 \mathrm{mmol})$ and 1,3,5trimethoxybenzene (1.1 mg, $0.0065 \mathrm{mmol}) .0 .5 \mathrm{~mL}$ of $\mathrm{C}_{6} \mathrm{D}_{6}$ was added, and the tube was sealed, removed from the glovebox, and the ${ }^{1} \mathrm{H}$ NMR spectrum recorded. The sample was degassed using 3 freeze-pump-thaw cycles, and kept under static vacuum. $\mathrm{O}_{2}$ was backfilled into the tube, and the tube was sealed. After taking an initial ${ }^{1} \mathrm{H}$ NMR spectrum, the sample was allowed heat to $60^{\circ} \mathrm{C}$ under an $\mathrm{O}_{2}$ atmosphere protected from light. The sample was occasionally inverted ( $\sim 30$ minute intervals) to aid in gas dissolution.

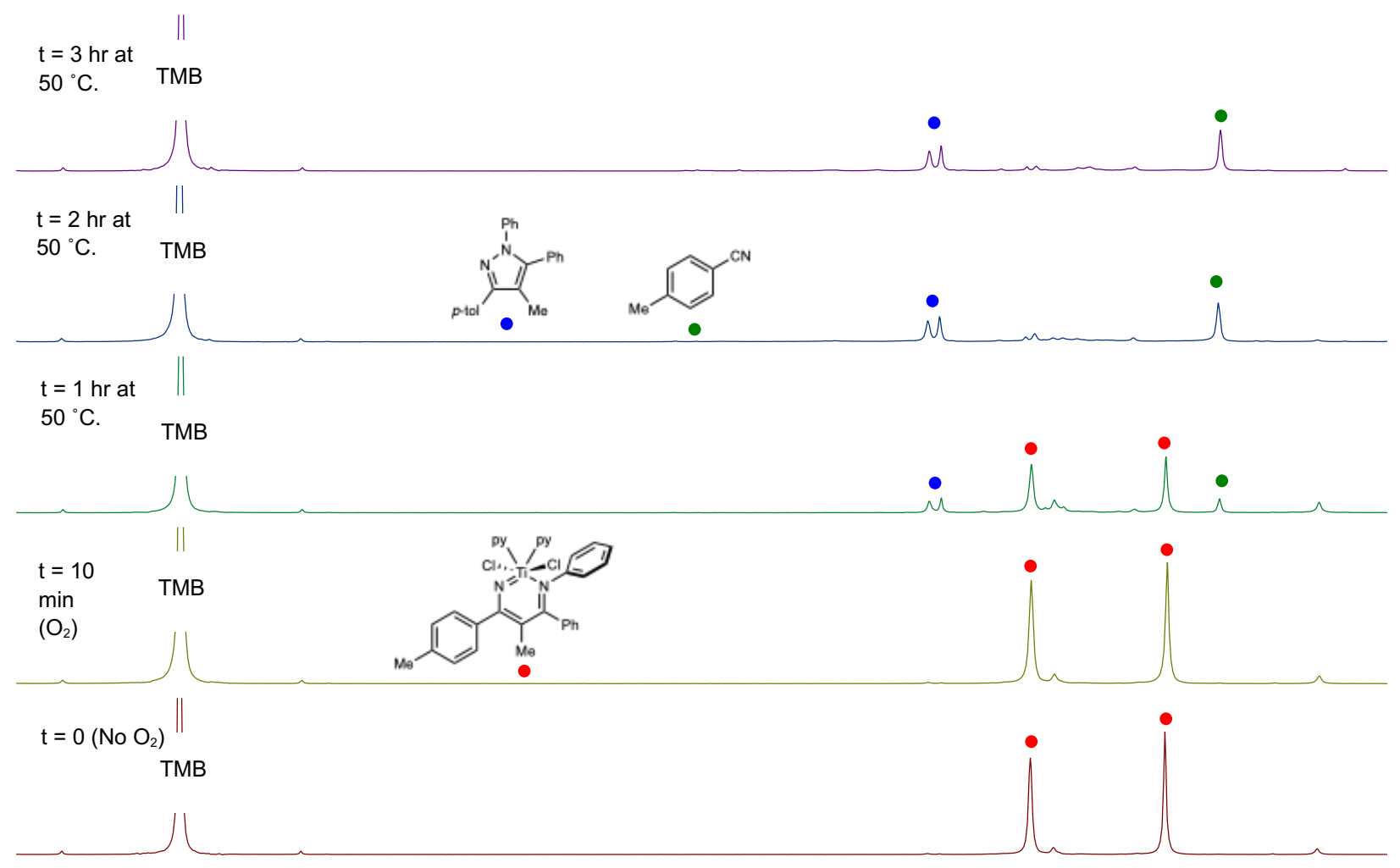

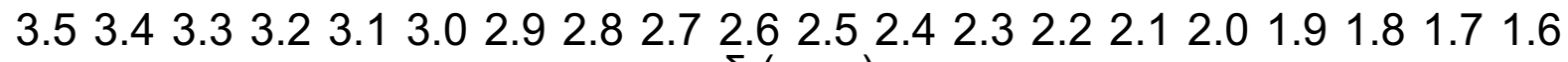 $\delta(\mathrm{ppm})$}

Figure S31. Stacked ${ }^{1} \mathrm{H}$ NMR spectra (alkyl region) characterizing the aerobic oxidation of 7 a over time. 


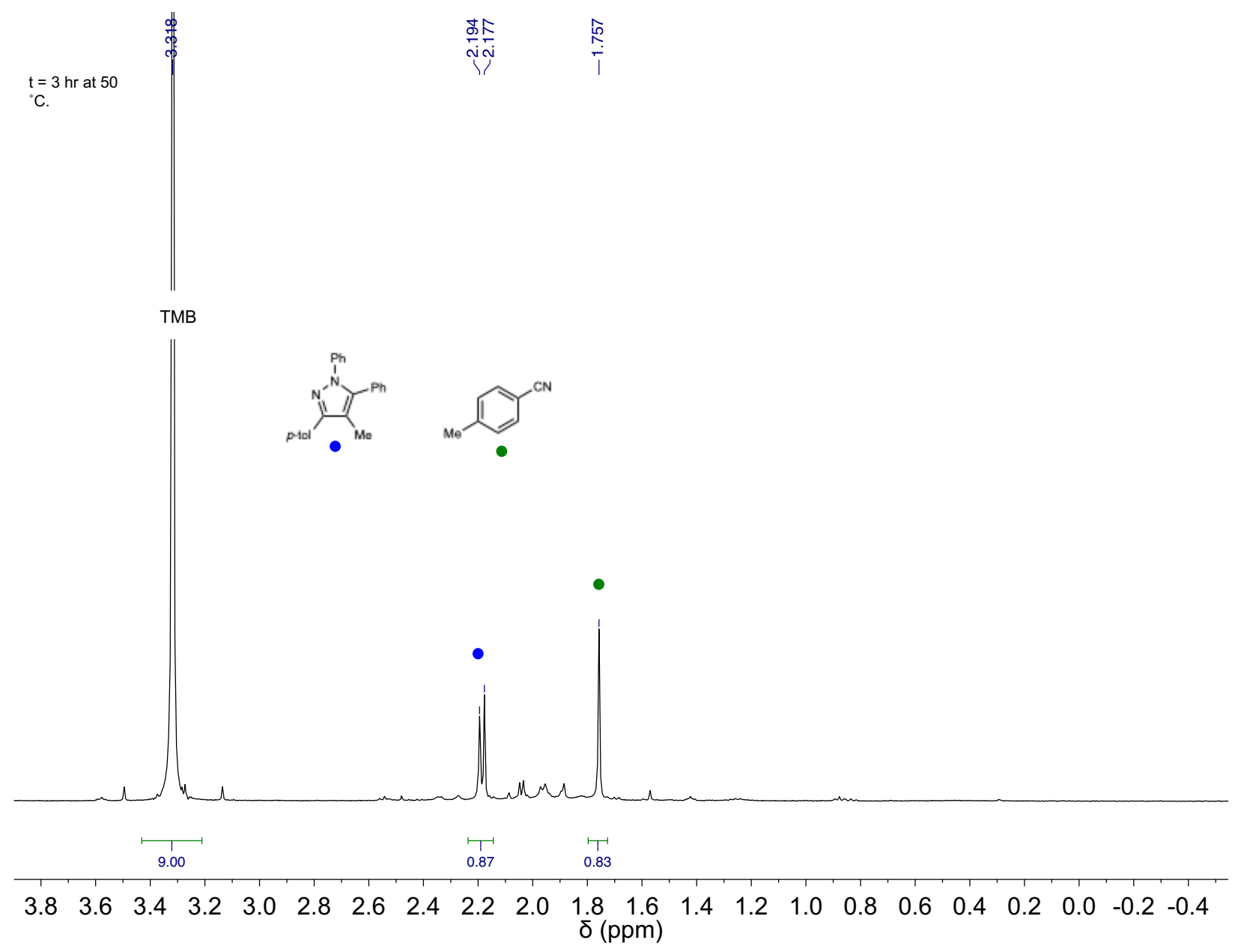

Figure S32. ${ }^{1} \mathrm{H}$ NMR of the $\mathrm{t}=3 \mathrm{~h}$ time point for the aerobic oxidation of $7 \mathrm{a}$.

\section{Multicomponent coupling of $\mathrm{py}_{2} \mathrm{TiCl}_{2}(\mathrm{NPh})$, alkynes and nitriles with TEMPO quench for the synthesis of pyrazoles (isolation conditions)}

$$
\mathrm{R}^{1} \mathrm{CN}+\underset{\mathrm{C}_{6} \mathrm{D}_{5} \mathrm{Br}, 115^{\circ} \mathrm{C}, 1 \mathrm{~h}}{\mathrm{R}_{2}}
$$

General procedure: In a $20 \mathrm{~mL}$ scintillation vial was added $\left[\mathrm{py}_{2} \mathrm{TiCl}_{2}(\mathrm{NPh})\right]_{2}(73.6 \mathrm{mg}, 0.200$ mmol, 1 equiv.), 0.200 mmol alkyne (1.00 equiv.), and $0.200 \mathrm{mmol}$ nitrile (1.00 equiv.). $2 \mathrm{~mL} \mathrm{of} \mathrm{PhBr}$ was added along with a stir bar, and the vial was sealed with a Teflon cap wrapped in electrical tape, brought out of the glovebox and heated in an oil bath to $115{ }^{\circ} \mathrm{C}$ with stirring for 4 hours. The 
heterogeneous yellow-orange mixture turns dark yellow upon heating. After the initial heating period, the vials were brought back into the glovebox, and TEMPO (62.5 mg, $0.400 \mathrm{mmol}, 2$ equiv.) was added. The vial was resealed and brought out of the glovebox, and the mixture was heated in an oil bath at $50{ }^{\circ} \mathrm{C}$ with stirring for 2 hours. The reactions where quenched by pipetting the reaction solution onto silica and eluted with DCM until the eluent no longer contained product (made visible by spotting on TLC and viewing under UV). The volatiles (including bromobenzene and, in some cases, volatile alkyne and nitrile reagents) were removed under vacuum. To remove any remaining impurity, the pyrazoles can be run through a pipet column $\left(\mathrm{SiO}_{2}, \mathrm{DCM}\right)$ to give pure $\mathbf{1 b} \mathbf{\mathbf { b }}$.

\section{4,5-diethyl-1,3-diphenyl-1H-pyrazole (1 b)}

Pale reddish oil. $62 \%$ isolated yield. ${ }^{1} \mathrm{H}$ NMR (400 MHz, $\left.\mathrm{CDCl}_{3}\right): \delta 7.73$ (d, 2H, ArH), $7.49(\mathrm{~m}, 4 \mathrm{H}, \mathrm{Ar}-\mathrm{H}), 7.41 \mathrm{f}(\mathrm{m}, 3 \mathrm{H}, \mathrm{Ar}-\mathrm{H}), 7.34$ (t, $1 \mathrm{H}, \mathrm{Ar}-\mathrm{H}), 2.73$ (q, 2H, $\mathrm{CH}_{2} \mathrm{CH}-$ 3), 2.68 (q, 2H, $\left.\mathrm{CH}_{2} \mathrm{CH}_{3}\right), 1.20$ (t, 3H, $\left.\mathrm{CH}_{2} \mathrm{CH}_{3}\right), 1.11$ (t, 3H, $\left.\mathrm{CH}_{2} \mathrm{CH}_{3}\right) .{ }^{13} \mathrm{C}$ NMR (101 $\mathrm{MHz}_{\mathrm{CDCl}}$ ): $\delta$ 150.47, 142.91, 140.38, 134.40, 129.16, 128.44, 127.96, 127.88, 127.48, 125.76, 118.64, 17.96, 17.21, 15.95, 14.24. ESI-HRMS (m/z): calcd. for $\mathrm{C}_{19} \mathrm{H}_{20} \mathrm{~N}_{2} \mathrm{Na}^{+}, 299.1524$; found, 299.1520.

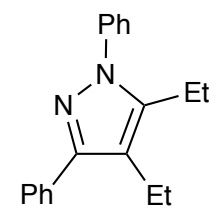

1b

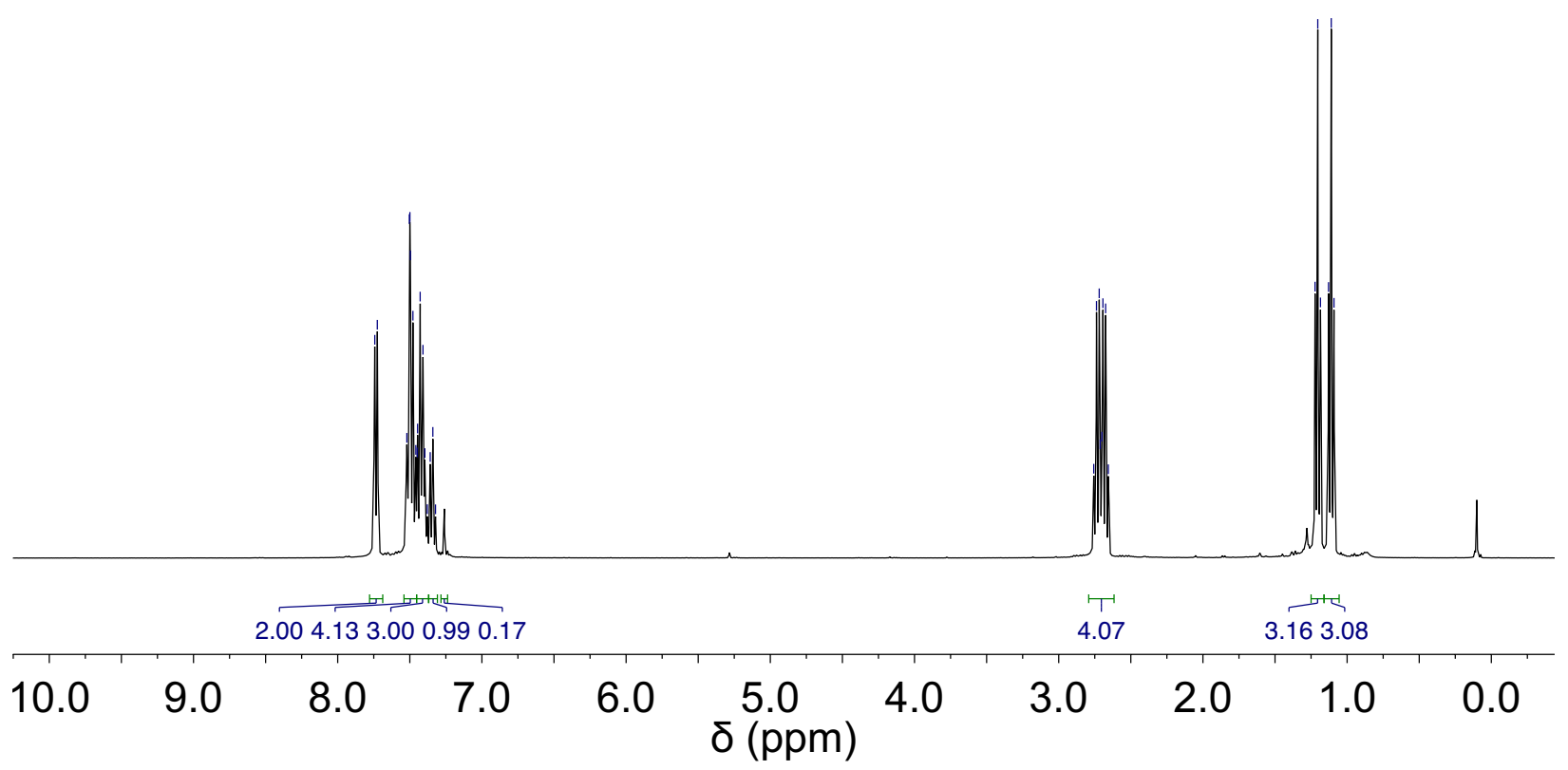

Figure S33. ${ }^{1} \mathrm{H}$ NMR spectrum of $1 \mathbf{b}$ in $\mathrm{CDCl}_{3}$. 

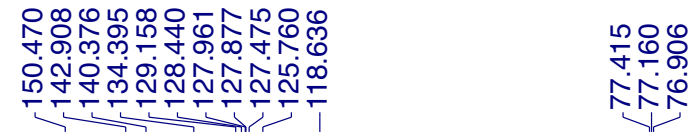

낭융ㅇㅇㅇㅜ

rivis

卦是

我更

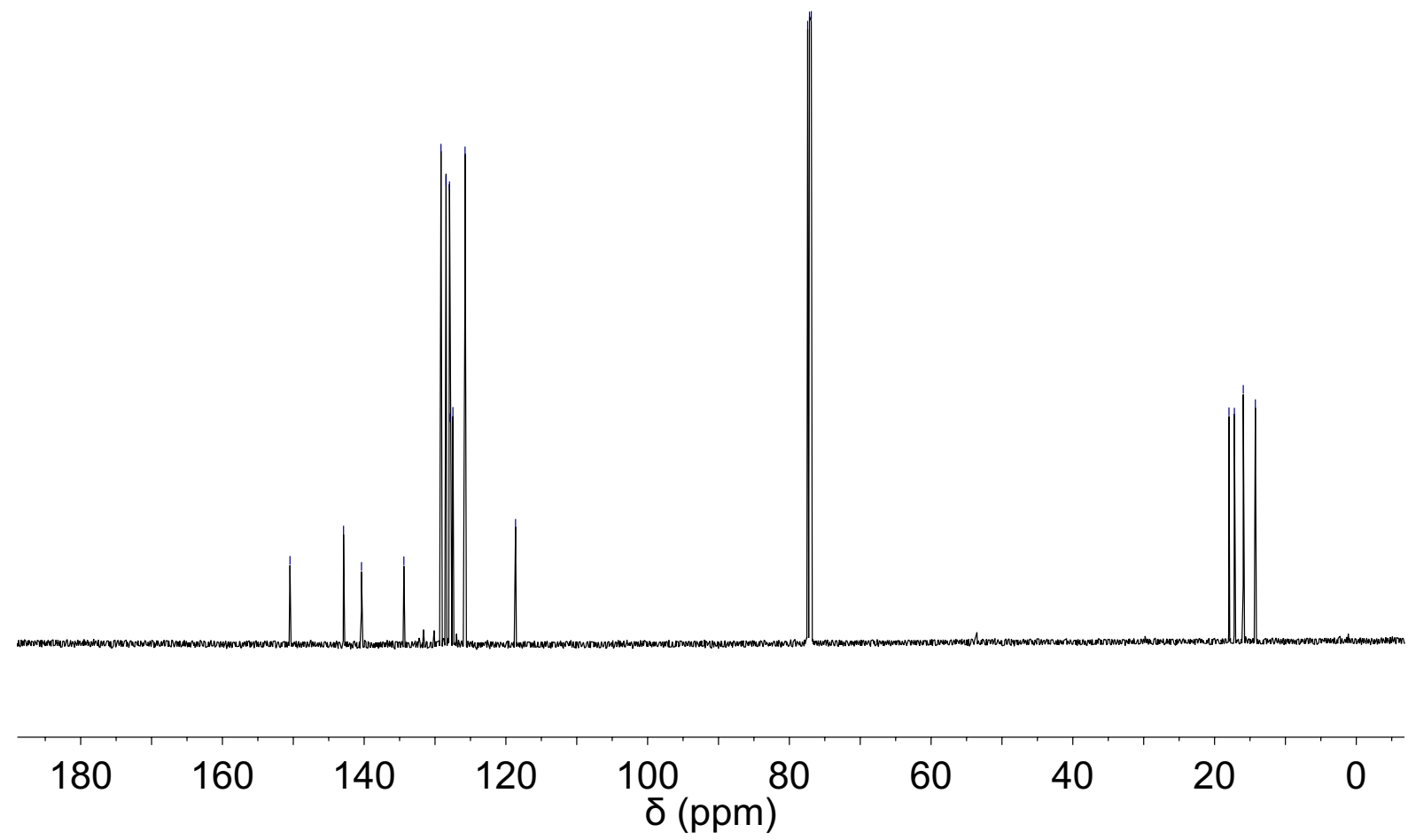

Figure S34. ${ }^{13} \mathrm{C}$ NMR spectrum of $1 \mathrm{~b}$ in $\mathrm{CDCl}_{3}$.

4,5-diethyl-3-(p-methoxyphenyl)-1-phenyl-1H-pyrazole (1c)

White solid. 47\% isolated yield. ${ }^{1} \mathrm{H}$ NMR (500 $\left.\mathbf{M H z}, \mathrm{CDCl}_{3}\right): \delta 7.65(\mathrm{~d}, \mathrm{~J}=$ $\left.8.3 \mathrm{~Hz}, 2 \mathrm{H}, \mathrm{MeO}-\mathrm{C}-(\mathrm{CHCH})_{2} \mathrm{C}\right), 7.52-7.43\left(\mathrm{~m}, 4 \mathrm{H}, \mathrm{N}-\mathrm{C}-(\mathrm{CHCH})_{2} \mathrm{CH}\right), 7.38$ (t, $\left.J=6.9 \mathrm{~Hz}, 1 \mathrm{H}, \mathrm{N}-\mathrm{C}-(\mathrm{CHCH})_{2} \mathrm{CH}\right), 6.96(\mathrm{~d}, J=8.3 \mathrm{~Hz}, 2 \mathrm{H}, \mathrm{MeO}-\mathrm{C}-$ $(\mathrm{CHCH})_{2} \mathrm{C}$ ), 3.84 (s, 3H, $\left.\mathrm{CH}_{3} \mathrm{O}-\right), 2.71$ (q, $J=7.5 \mathrm{~Hz}, 2 \mathrm{H}, \mathrm{CH}_{2} \mathrm{CH}_{3}$ ), 2.65 (q, J $\left.=7.5 \mathrm{~Hz}, 2 \mathrm{H}, \mathrm{CH}_{2} \mathrm{CH}_{3}\right), 1.18\left(\mathrm{t}, J=7.5 \mathrm{~Hz}, 3 \mathrm{H}, \mathrm{CH}_{2} \mathrm{CH}_{3}\right), 1.09(\mathrm{t}, J=7.5 \mathrm{~Hz}$, $\left.3 \mathrm{H}, \mathrm{CH}_{2} \mathrm{CH}_{3}\right) .{ }^{13} \mathrm{C}$ NMR (126 MHz, $\left.\mathrm{CDCl}_{3}\right): \delta$ 159.20, 150.26, 142.86, 140.41, 129.18 (2C), 127.84, 126.99, 125.79, 118.38, 113.92, 55.38, 18.00, 17.26, 15.95, 14.28. ESI-HRMS (m/z): calcd. for $\mathrm{C}_{20} \mathrm{H}_{22} \mathrm{~N}_{2} \mathrm{ONa}^{+}$, 329.1630; found,<smiles>CCc1c(-c2ccc(OC)cc2)nn(-c2ccccc2)c1CC</smiles>
329.1631. 

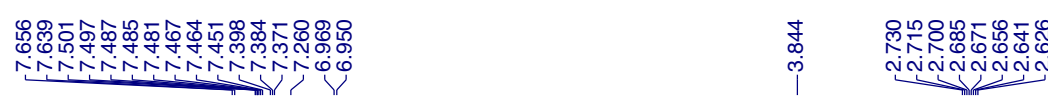

N

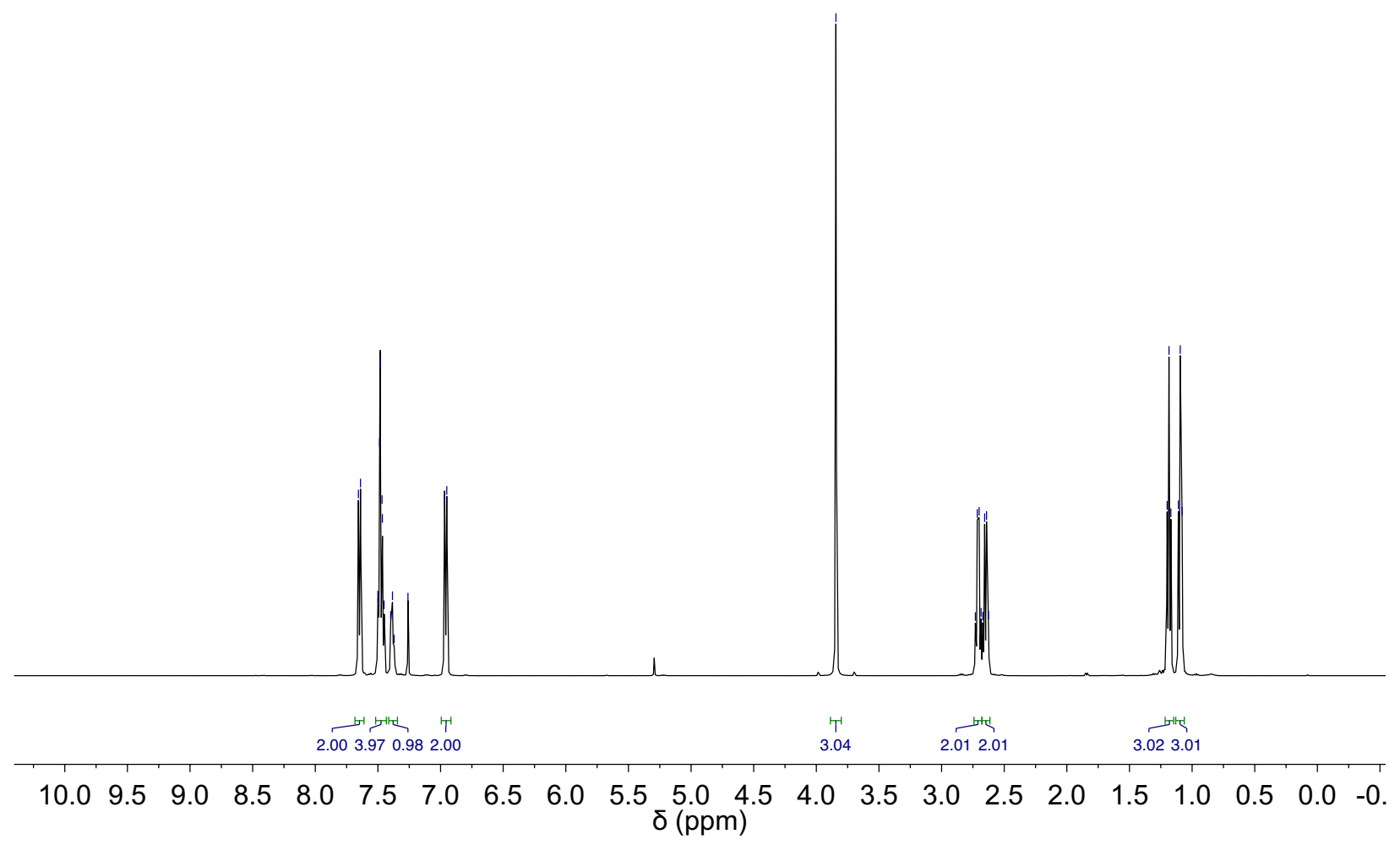

Figure S35. ${ }^{1} \mathrm{H}$ NMR spectrum of $1 \mathrm{c}$ in $\mathrm{CDCl}_{3}$. 


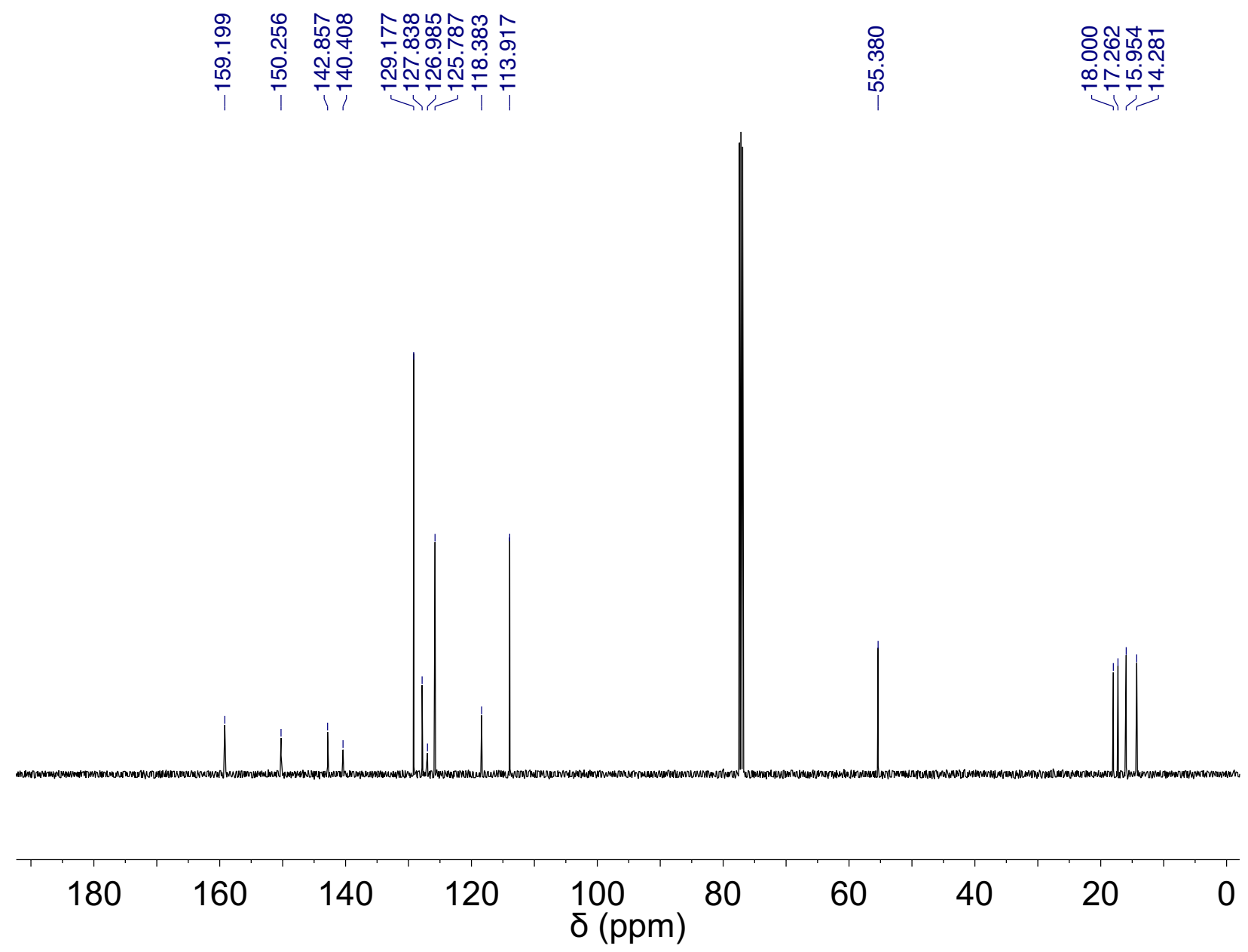

Figure S36. ${ }^{13} \mathrm{C}$ NMR spectrum of $1 \mathrm{c}$ in $\mathrm{CDCl}_{3}$.

4,5-diethyl-1-phenyl-3-(p-(trifluoromethyl)phenyl)-1H-pyrazole (1d)

White solid. $29 \%$ isolated yield. ${ }^{1} \mathrm{H}$ NMR (400 $\left.\mathbf{M H z}, \mathrm{CDCl}_{3}\right): \delta 7.85$ (d, $J=8.1$ $\left.\mathrm{Hz}, 2 \mathrm{H}, \mathrm{F}_{3} \mathrm{C}-\mathrm{C}-(\mathrm{CHCH})_{2} \mathrm{C}\right), 7.67\left(\mathrm{~d}, \mathrm{~J}=8.2 \mathrm{~Hz}, 2 \mathrm{H}, \mathrm{F}_{3} \mathrm{C}-\mathrm{C}-(\mathrm{CHCH})_{2} \mathrm{C}\right), 7.49$ $\left(\mathrm{m}, 4 \mathrm{H}, \mathrm{N}-\mathrm{C}-(\mathrm{CHCH})_{2}-\mathrm{CH}\right), 7.46-7.38\left(\mathrm{~m}, 1 \mathrm{H}, \mathrm{N}-\mathrm{C}-(\mathrm{CHCH})_{2}-\mathrm{CH}\right), 2.73$ (q, J $\left.=7.7 \mathrm{~Hz}, 2 \mathrm{H}, \mathrm{CH}_{2} \mathrm{CH}_{3}\right), 2.68\left(\mathrm{q}, J=7.7 \mathrm{~Hz}, 2 \mathrm{H}, \mathrm{CH}_{2} \mathrm{CH}_{3}\right), 1.20(\mathrm{t}, J=7.6 \mathrm{~Hz}$, $\left.3 \mathrm{H}, \mathrm{CH}_{2} \mathrm{CH}_{3}\right), 1.10\left(\mathrm{t}, J=7.5 \mathrm{~Hz}, 3 \mathrm{H}, \mathrm{CH}_{2} \mathrm{CH}_{3}\right) .{ }^{13} \mathrm{C} \mathrm{NMR}\left(126 \mathrm{MHz}_{2} \mathrm{CDCl}_{3}\right): \delta$ 148.94, 143.47, 140.16, 138.05, 129.40 (q, 32.3 Hz), 129.32, 128.27, 128.03, 125.84, 125.45 (q, $3.9 \mathrm{~Hz}), 124.50$ (q, $272.5 \mathrm{~Hz}), 119.00,17.96,17.25,15.91$, 14.26. ${ }^{19} \mathrm{~F} \mathrm{NMR}$ (376 MHz, $\left.\mathrm{CDCl}_{3}\right)$ : $\delta-61.23$ (vs. TFA). ESI-HRMS (m/z):

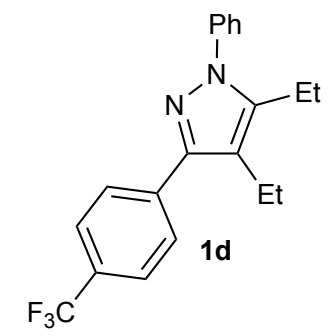
calcd. for $\mathrm{C}_{20} \mathrm{H}_{19} \mathrm{~F}_{3} \mathrm{~N}_{2} \mathrm{Na}^{+}$, 367.1398; found, 367.1409. 

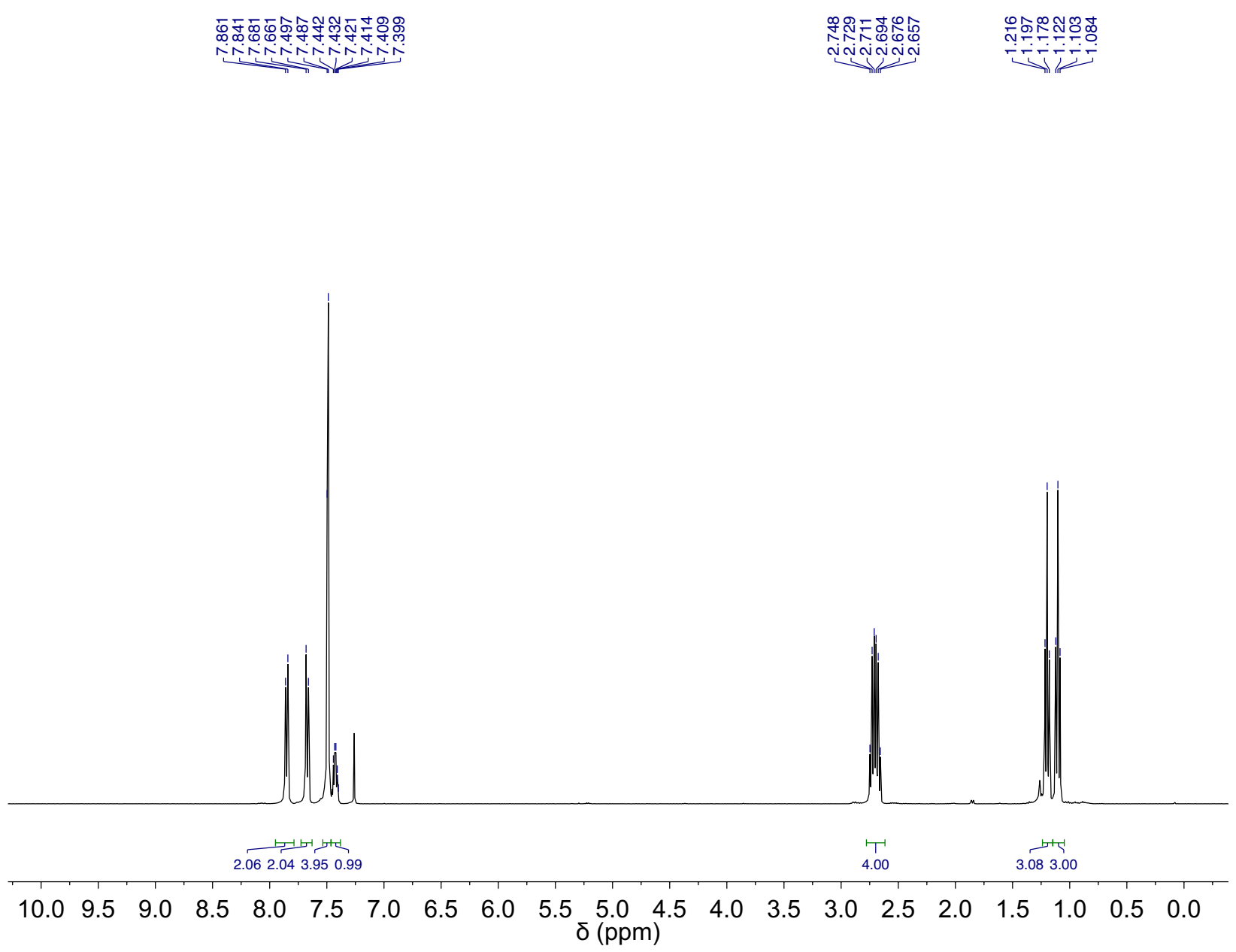

Figure S37. ${ }^{1} \mathrm{H}$ NMR spectrum of $1 \mathrm{~d}$ in $\mathrm{CDCl}_{3}$. 


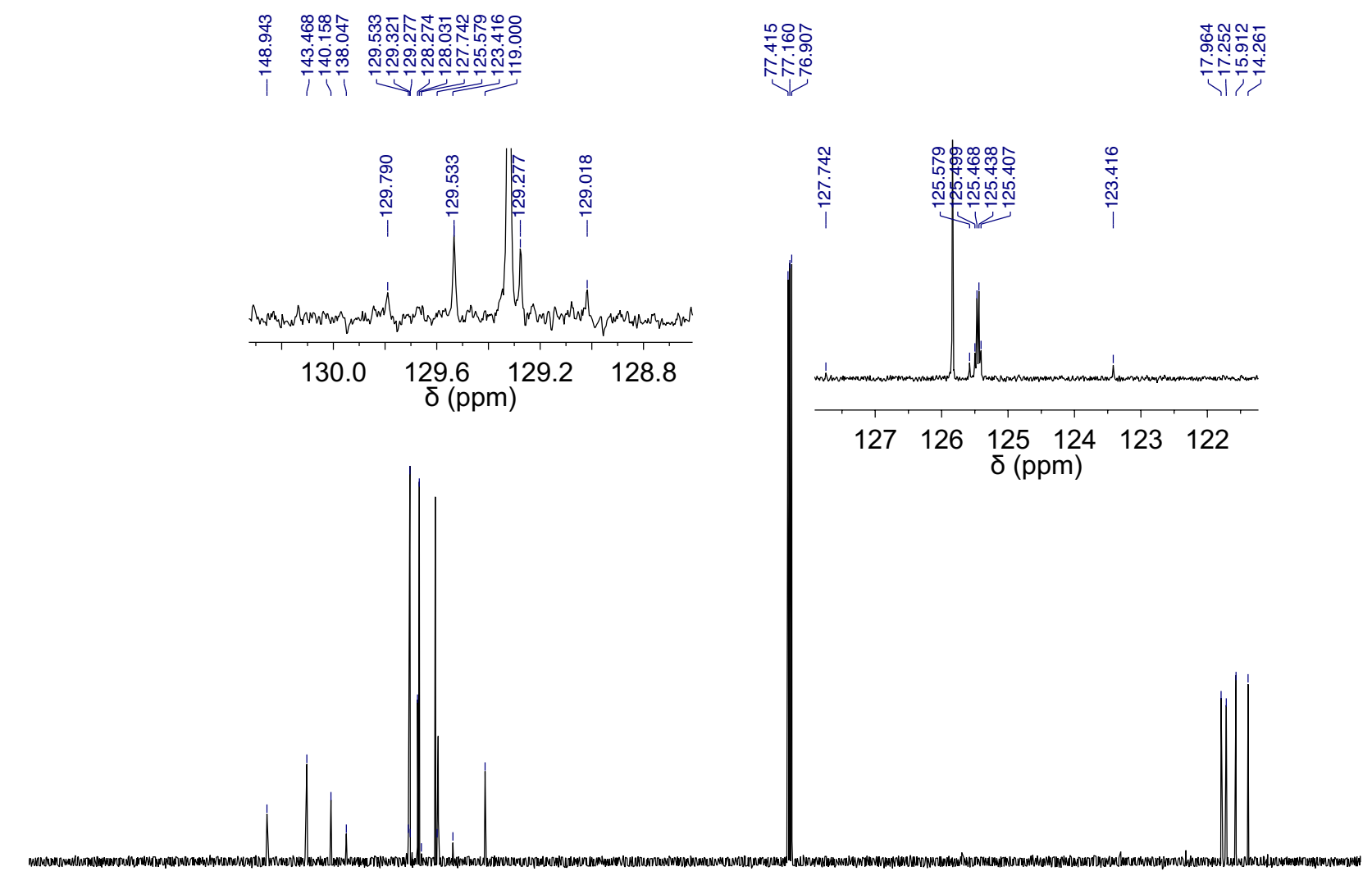

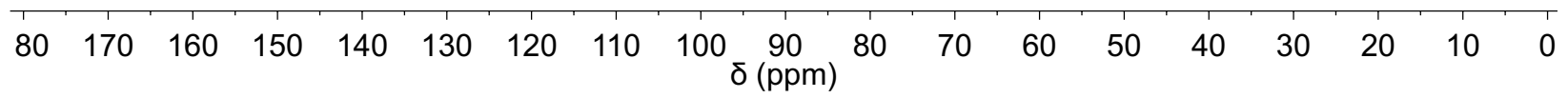

Figure S38. ${ }^{13} \mathrm{C}$ NMR spectrum of $1 \mathrm{~d}$ in $\mathrm{CDCl}_{3}$, with insets showing a zoomed-in view of ${ }^{13} \mathrm{C}-{ }^{19} \mathrm{~F}$ coupling for quartet at $129.40 \mathrm{ppm}(32.3 \mathrm{~Hz})$, and the other showing a zoomed in view of ${ }^{13} \mathrm{C}-{ }^{19} \mathrm{~F}$ coupling for quartets at $125.45 \mathrm{ppm}(3.9 \mathrm{~Hz})$ and $124.50 \mathrm{ppm}(272.5 \mathrm{~Hz})$. Quartet centered at 124.50 ppm most upfield signal not visible. 


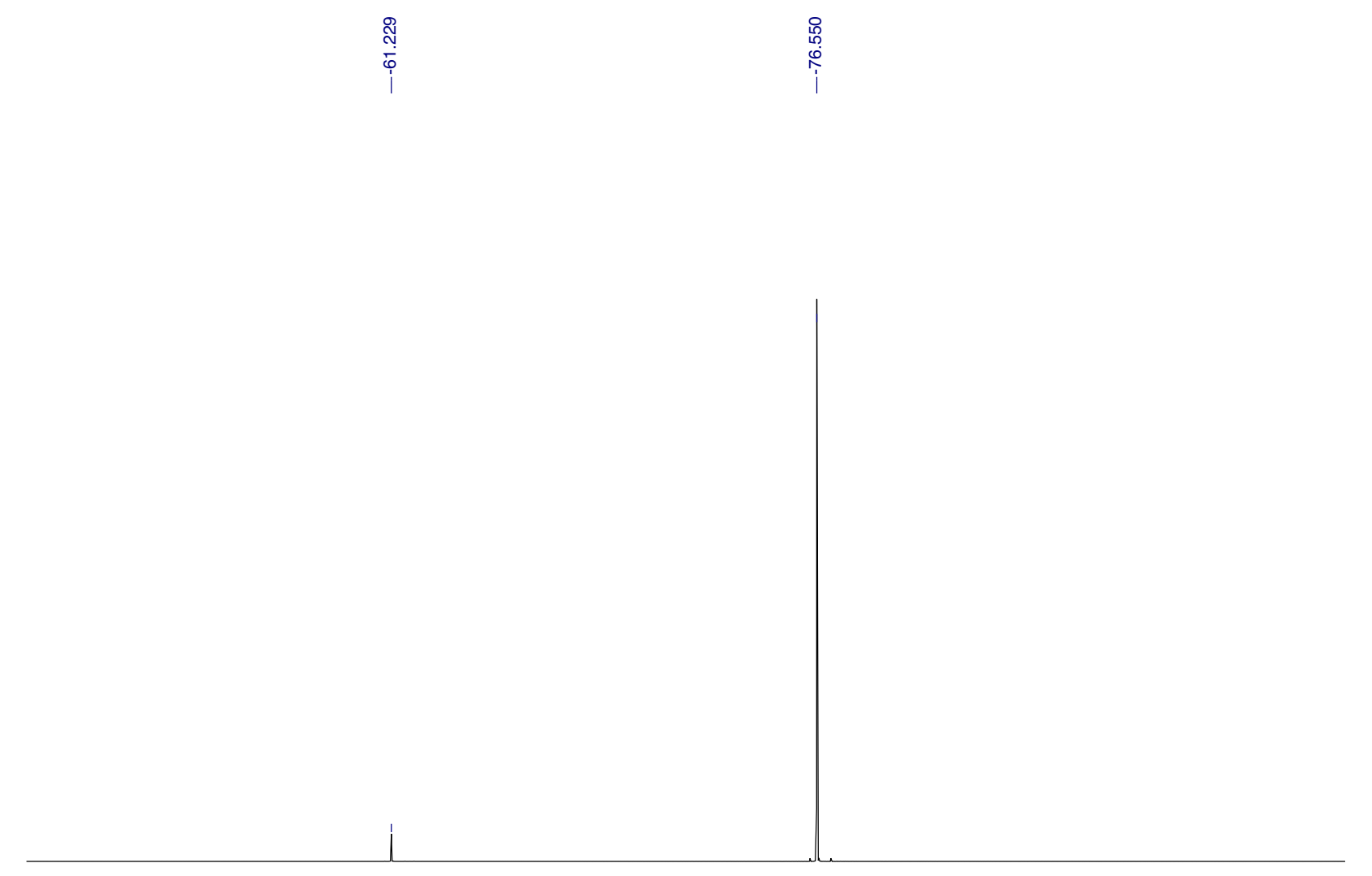

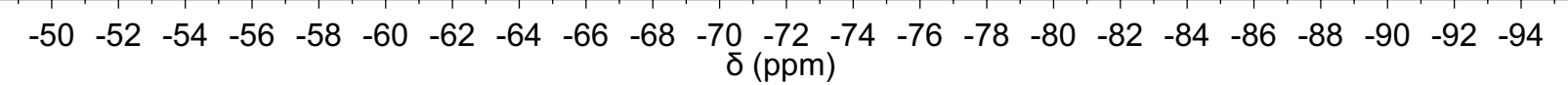

Figure S39. ${ }^{19} \mathrm{~F}$ NMR spectrum of $1 \mathrm{~d}$ in $\mathrm{CDCl}_{3}$, with trifluoroacetic acid reference capillary (set to 76.550ppm).

4,5-diethyl-3-isopropyl-1-phenyl-1H-pyrazole (1e)

Colorless oil. $56 \%$ isolated yield. ${ }^{1} \mathrm{H}$ NMR (400 MHz, $\left.\mathbf{C D C l}_{3}\right): \delta 7.48-7.39(\mathrm{~m}$, $4 \mathrm{H}, \mathrm{Ar}-\mathrm{H}), 7.37-7.29(\mathrm{~m}, 1 \mathrm{H}, \mathrm{Ar}-H), 3.02$ (hept, $J=7.0 \mathrm{~Hz}, 1 \mathrm{H},-\mathrm{CHMe}$ ), 2.63 (q, $\left.J=7.6 \mathrm{~Hz}, 2 \mathrm{H},-\mathrm{CH}_{2} \mathrm{CH}_{3}\right), 2.47\left(\mathrm{q}, J=7.6 \mathrm{~Hz}, 2 \mathrm{H}, \mathrm{CH}_{2} \mathrm{CH}_{3}\right), 1.34(\mathrm{~d}, J=7.0$ $\left.\mathrm{Hz}, 6 \mathrm{H},-\mathrm{CH}\left(\mathrm{CH}_{3}\right)_{2}\right), 1.17\left(\mathrm{t}, J=7.6 \mathrm{~Hz}, 3 \mathrm{H},-\mathrm{CH}_{2} \mathrm{CH}_{3}\right), 1.05(\mathrm{t}, J=7.6 \mathrm{~Hz}, 3 \mathrm{H}$, $\left.\mathrm{CH}_{2} \mathrm{CH}_{3}\right) .{ }^{13} \mathrm{C}$ NMR (126 MHz, $\left.\mathrm{CDCl}_{3}\right): \delta$ 156.72, 141.68, 140.68, 129.08, 127.36, 125.60, 117.74, 26.61, 22.79, 17.90, 16.70, 16.40, 14.27. ESI-HRMS (m/z): calcd. for $\mathrm{C}_{16} \mathrm{H}_{22} \mathrm{~N}_{2} \mathrm{Na}^{+}$, 265.1681; found, 265.1679.

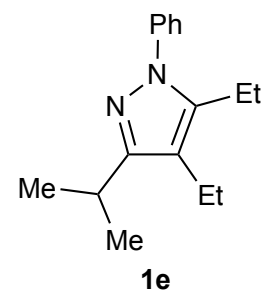




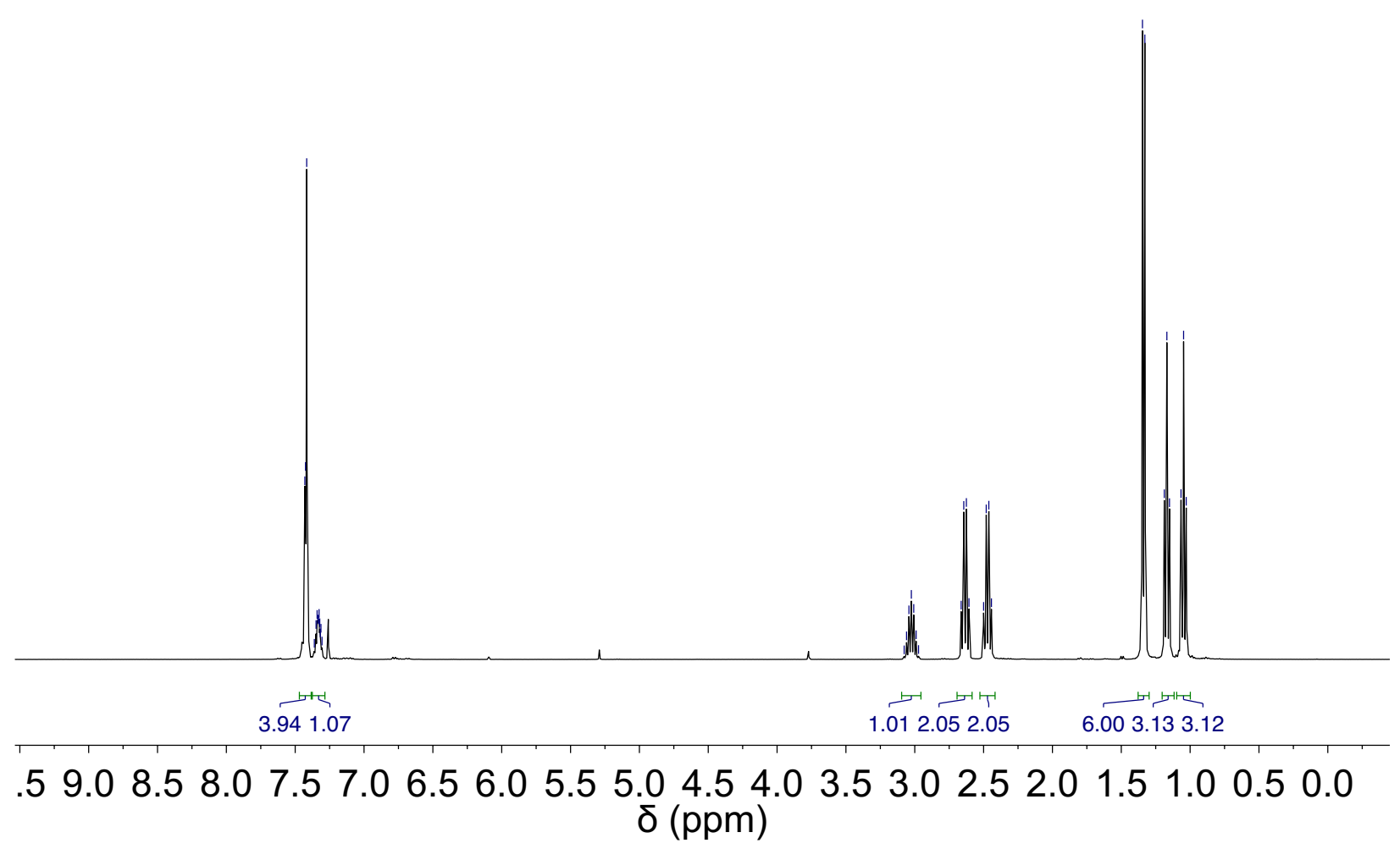

Figure $540 .{ }^{1} \mathrm{H}$ NMR spectrum of $1 \mathrm{e}$ in $\mathrm{CDCl}_{3}$. 


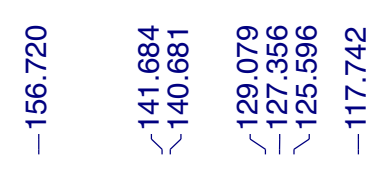

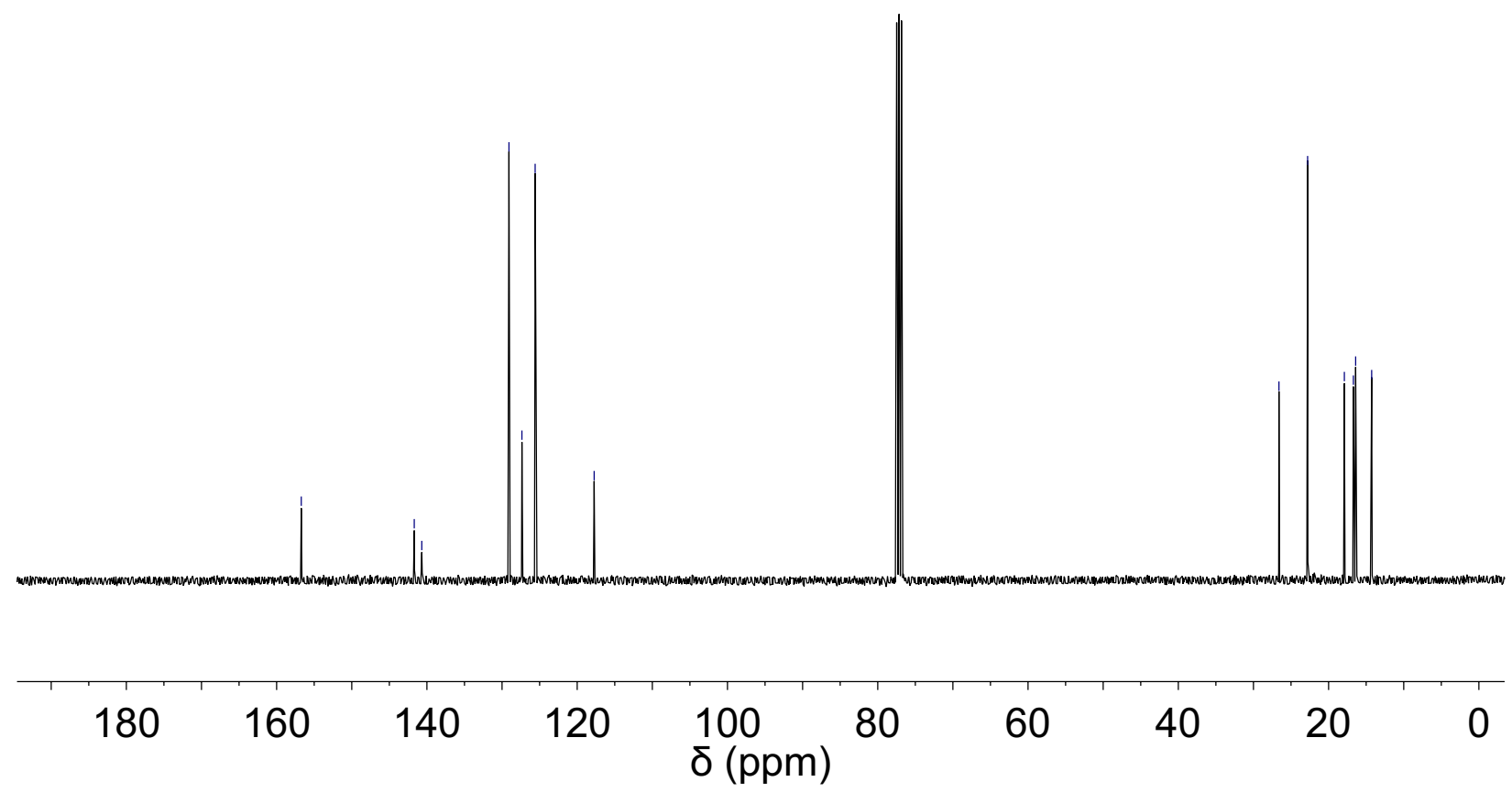

Figure $\mathrm{S} 41 .{ }^{13} \mathrm{C}$ NMR spectrum of $1 \mathrm{e}$ in $\mathrm{CDCl}_{3}$.

3,5-dimethyl-1,4-diphenyl-1H-pyrazole (1g)

Pale yellow solid. $30 \%$ isolated yield. ${ }^{1} \mathrm{H}$ NMR (400 $\left.\mathbf{M H z}, \mathrm{CDCl}_{3}\right)$ : $\delta 7.57-7.45(\mathrm{~m}$, $6 \mathrm{H}, \mathrm{Ar}-\mathrm{H}), 7.44-7.33(\mathrm{~m}, 4 \mathrm{H}, \mathrm{Ar}-\mathrm{H}), 2.39\left(\mathrm{~s}, 3 \mathrm{H}, \mathrm{CH}_{3}\right), 2.36\left(\mathrm{~s}, 3 \mathrm{H}, \mathrm{CH}_{3}\right) .{ }^{13} \mathrm{C} \mathrm{NMR}$ (101 MHz, $\mathrm{CDCl}_{3}$ ): $\delta$ 146.51, 139.31, 135.67, 133.20, 128.92, 128.45, 127.83, $126.78,125.80,124.33,120.25,12.05,11.21$. ESI-HRMS (m/z): calcd. for $\mathrm{C}_{17} \mathrm{H}-$ ${ }_{16} \mathrm{~N}_{2} \mathrm{Na}^{+}, 271.1211$; found, 271.1203.

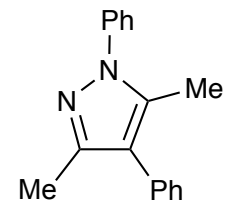



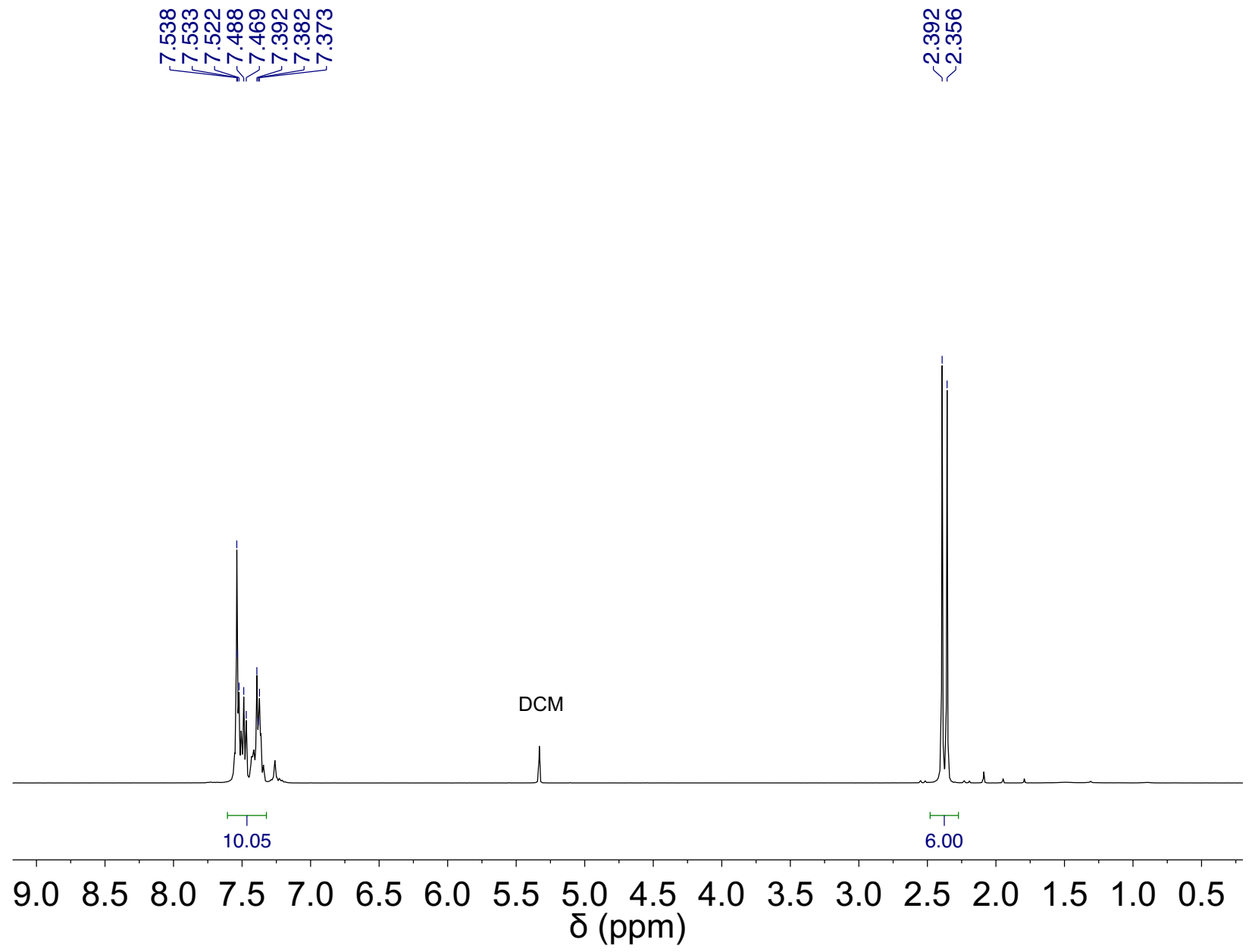

Figure S42. ${ }^{1} \mathrm{H}$ NMR spectrum of $1 \mathrm{~g}$ in $\mathrm{CDCl}_{3}$. 

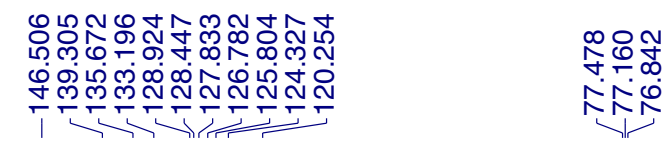

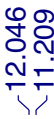

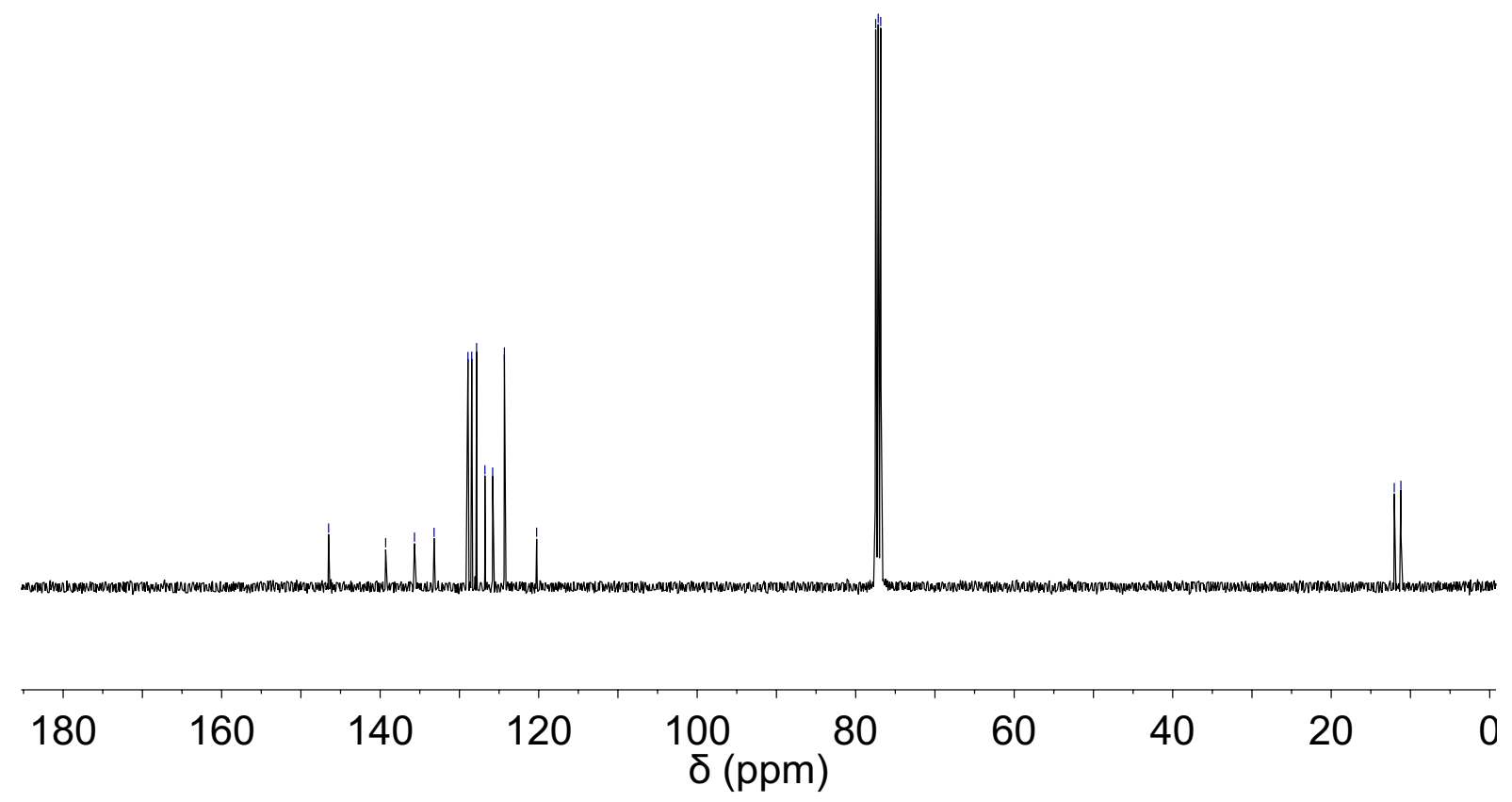

Figure S43. ${ }^{13} \mathrm{C}$ NMR spectrum of $1 \mathrm{~g}$ in $\mathrm{CDCl}_{3}$. 


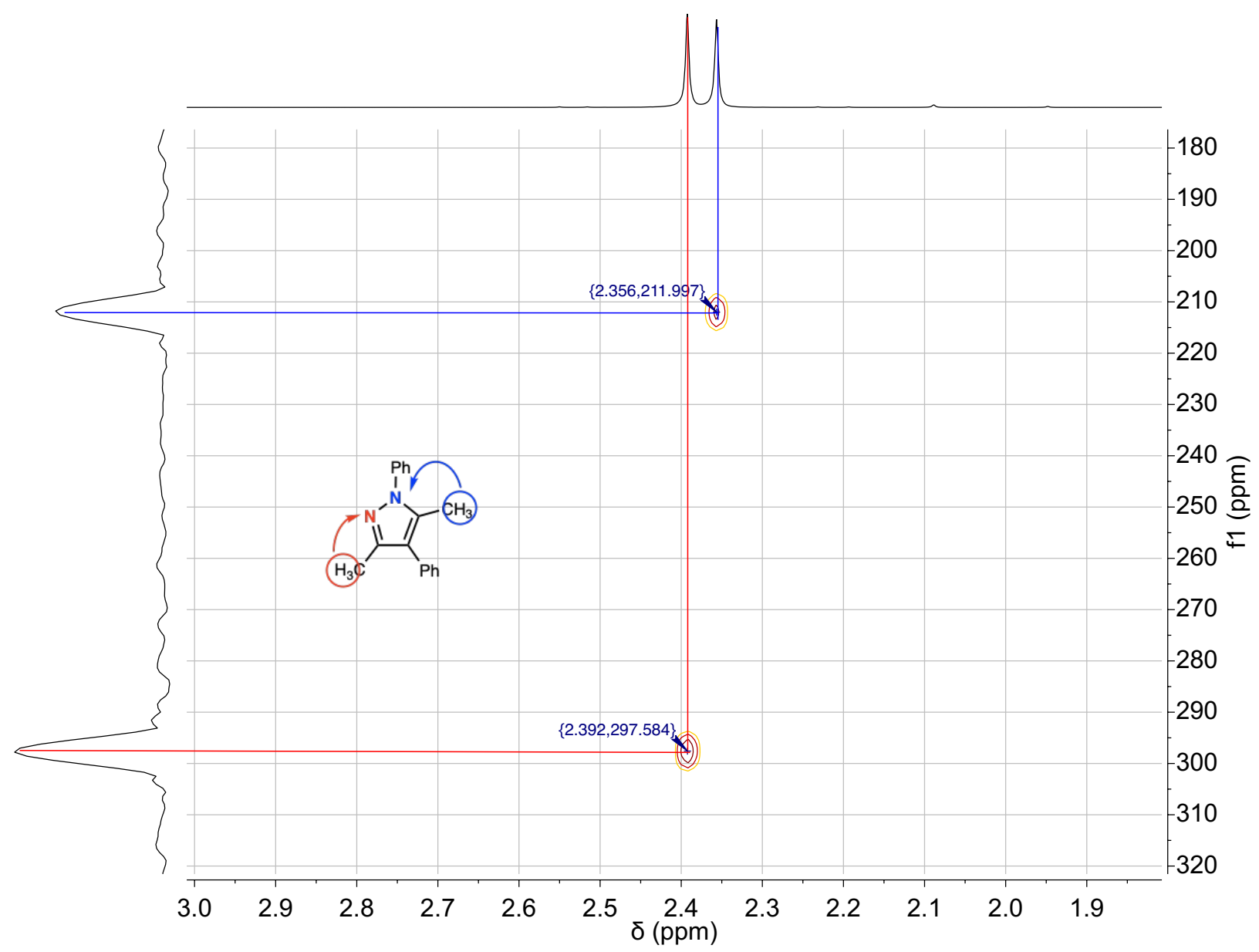

Figure S44. ${ }^{1} \mathrm{H}^{-15} \mathrm{~N}$ HMBC NMR spectrum of $1 \mathrm{e}$ in $\mathrm{CDCl}_{3}$.

5-methyl-1,3,4-triphenyl-1H-pyrazole (1h)

Light brown solid. 43\% isolated yield. ${ }^{1} \mathrm{H}$ NMR (400 $\left.\mathbf{M H z}, \mathrm{CDCl}_{3}\right)$ : $\delta 7.61-7.55(\mathrm{~m}$, $\left.2 \mathrm{H}, \mathrm{N}-\mathrm{C}\left(\mathrm{CH}_{2} \mathrm{CH}_{2}\right) \mathrm{CH}\right), 7.54-7.46(\mathrm{~m}, 4 \mathrm{H}, \mathrm{Ar}-\mathrm{H}), 7.42-7.33(\mathrm{~m}, 3 \mathrm{H}, \mathrm{Ar}-\mathrm{H}), 7.33-$ 7.19 (m, 6H Ar-H), 2.31 (s, 3H, $\left.\mathrm{CH}_{3}\right) .{ }^{13} \mathrm{C}$ NMR (101 MHz, $\left.\mathbf{C D C l}_{3}\right): \delta$ 149.79, 140.09, $137.75,134.02,133.43,130.45,129.25,128.59,128.25$ (2C), 127.82, 127.57, 126.87, 125.26, 120.24, 11.83. ESI-HRMS (m/z): calcd. for $\mathrm{C}_{22} \mathrm{H}_{18} \mathrm{~N}_{2} \mathrm{Na}^{+}$, 333.1363; found, 333.1368 .

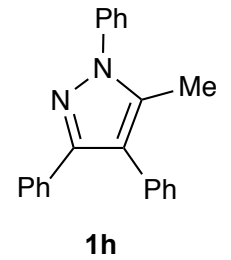




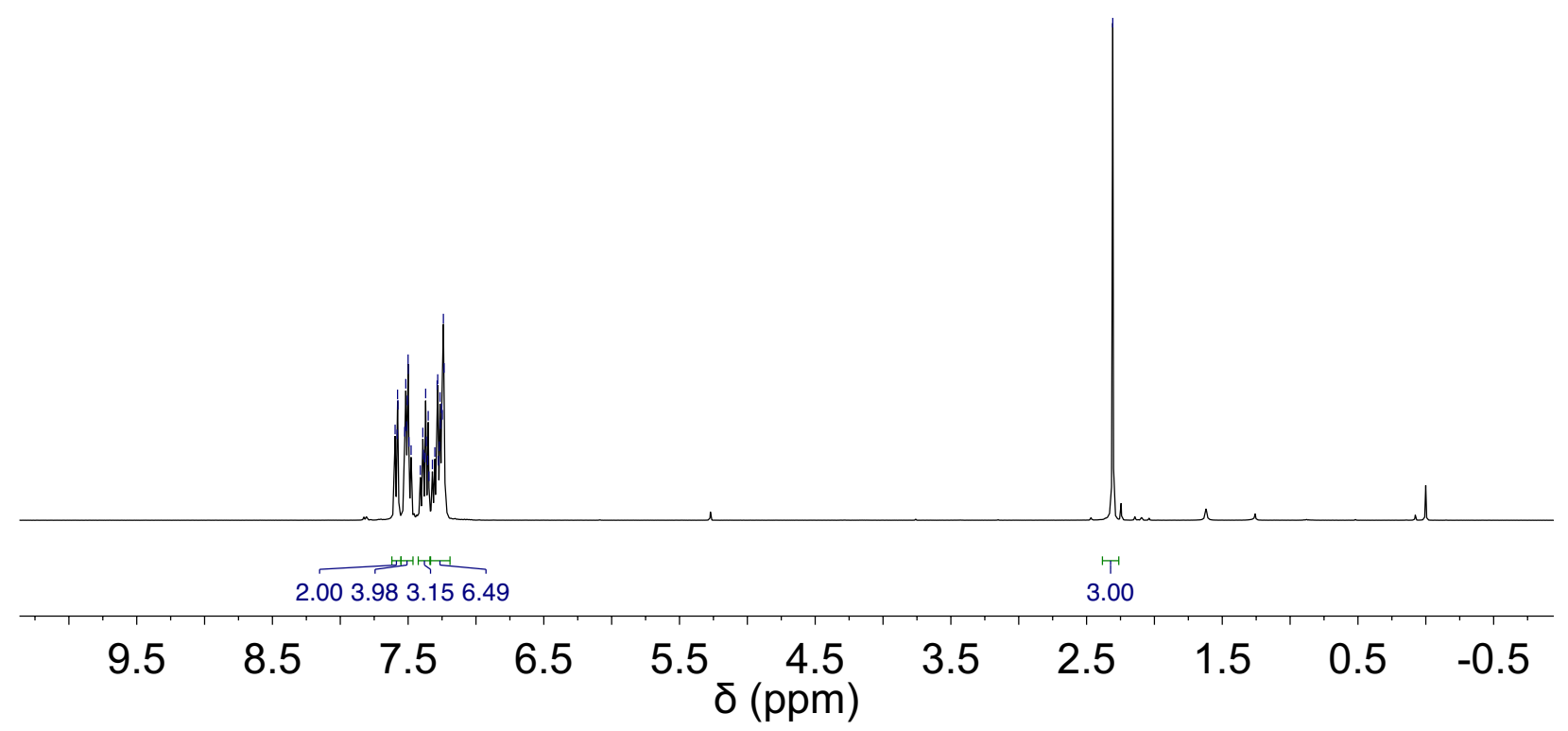

Figure S45. ${ }^{1} \mathrm{H}$ NMR spectrum of $1 \mathrm{~h}$ in $\mathrm{CDCl}_{3}$. 


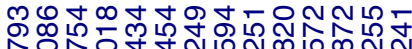
ơं

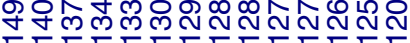

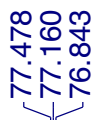

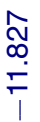

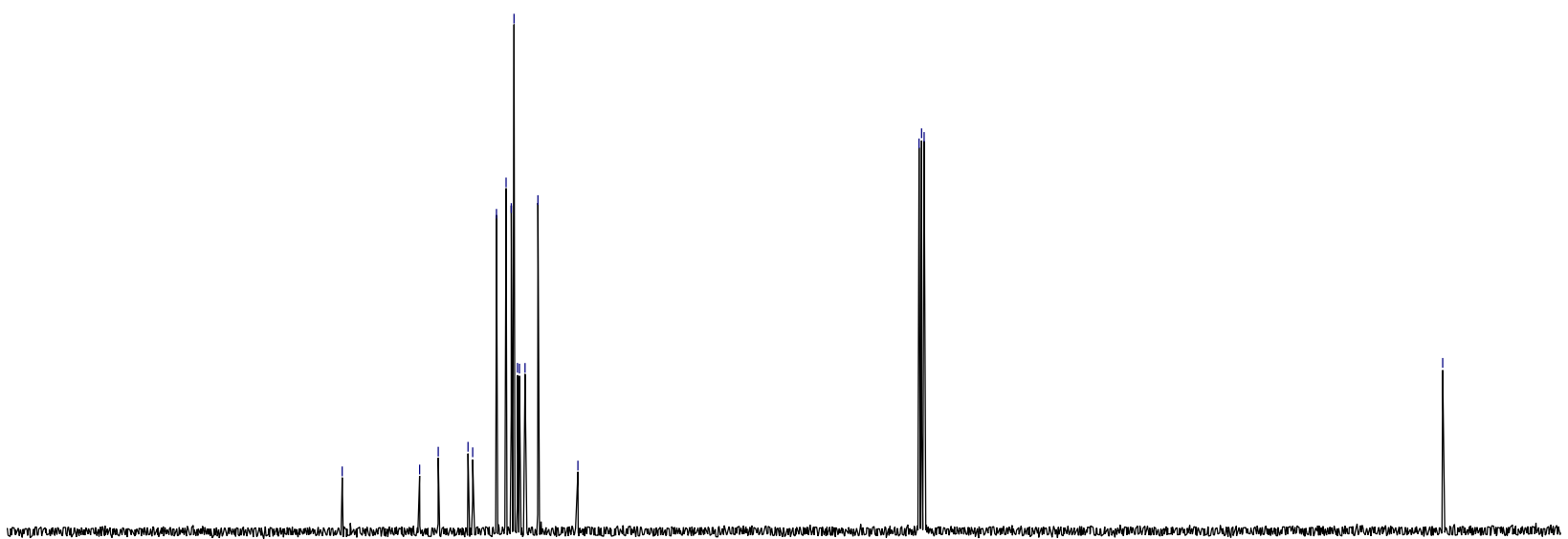

\begin{tabular}{|c|c|c|c|c|c|c|c|c|}
\hline 180 & 160 & 140 & 120 & $\begin{array}{l}100 \\
\delta(p p m)\end{array}$ & 80 & 60 & 40 & 20 \\
\hline
\end{tabular}

Figure S46. ${ }^{13} \mathrm{C}$ NMR spectrum of $1 \mathrm{~h}$ in $\mathrm{CDCl}_{3}$. 


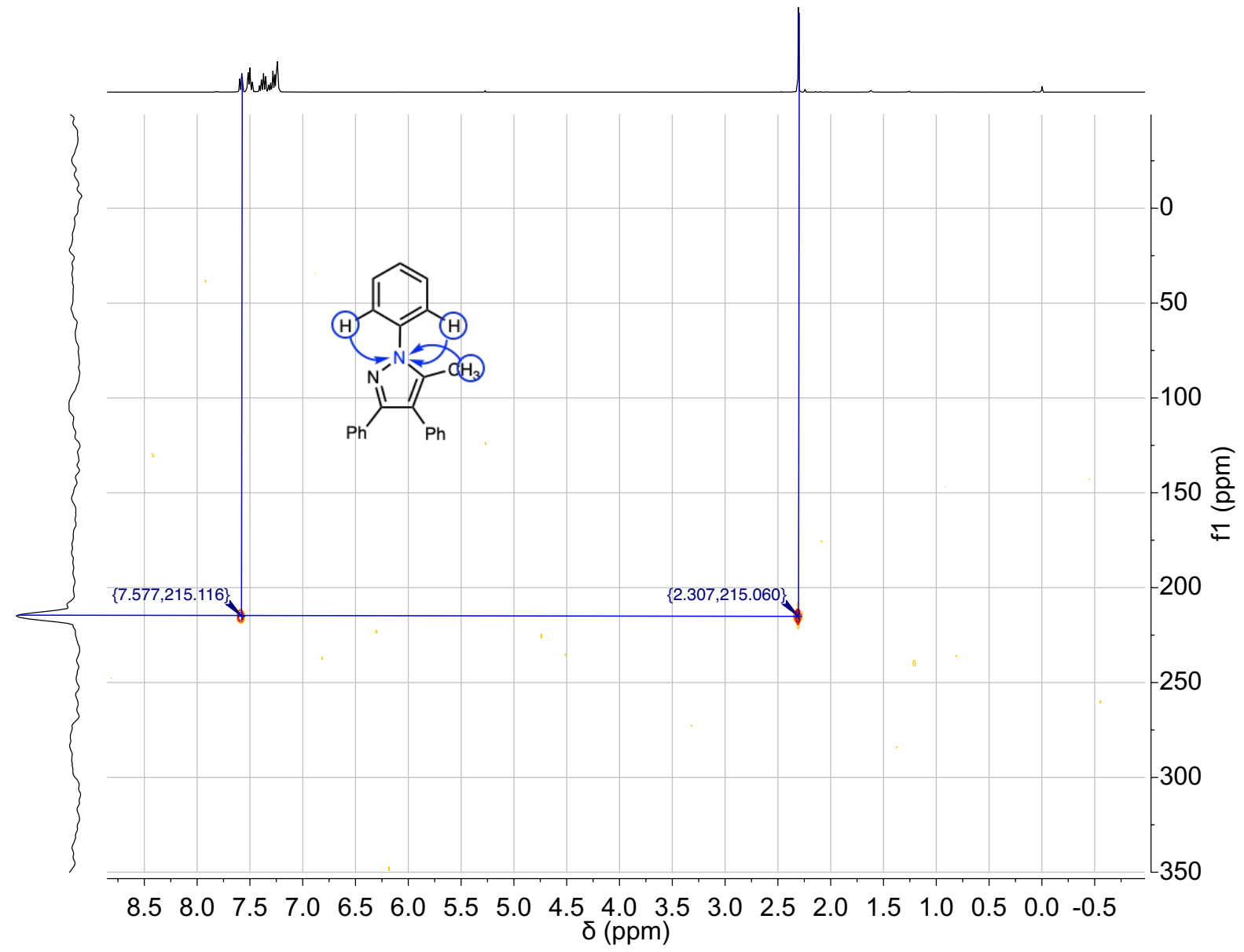

Figure S47. ${ }^{1} \mathrm{H}^{-15} \mathrm{~N}$ HMBC NMR spectrum of $1 \mathrm{~h}$ in $\mathrm{CDCl}_{3}$.

4,5-dimethyl-1,3-diphenyl-1H-pyrazole (1i)

Pale yellow solid. 42\% isolated yield. ${ }^{1} \mathrm{H}$ NMR (400 $\mathbf{M H z}, \mathbf{C D C l}_{3}$ ): $\delta 7.75$ (d, $J=7.2$ $\mathrm{Hz}, 2 \mathrm{H}, \mathrm{Ar}-\mathrm{H}), 7.54-7.41(\mathrm{~m}, 6 \mathrm{H}, \mathrm{Ar}-\mathrm{H}), 7.41-7.31(\mathrm{~m}, 2 \mathrm{H}, \mathrm{Ar}-\mathrm{H}), 2.31$ (s, 3H, $\left.\mathrm{CH}_{3}\right), 2.23\left(\mathrm{~s}, 3 \mathrm{H}, \mathrm{CH}_{3}\right) .{ }^{13} \mathrm{C}$ NMR (101 MHz, $\left.\mathrm{CDCl}_{3}\right): \delta 150.82,140.23,137.32$, 134.22, 129.16, 128.48, 127.95, 127.51, 125.16, 112.77, 11.17, 9.86. ESI-HRMS (m/z): calcd. for $\mathrm{C}_{17} \mathrm{H}_{16} \mathrm{~N}_{2} \mathrm{Na}^{+}, 271.1211$; found, 271.1210 .

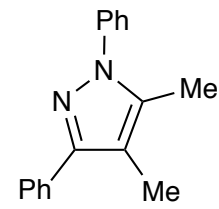

$1 \mathrm{i}$ 


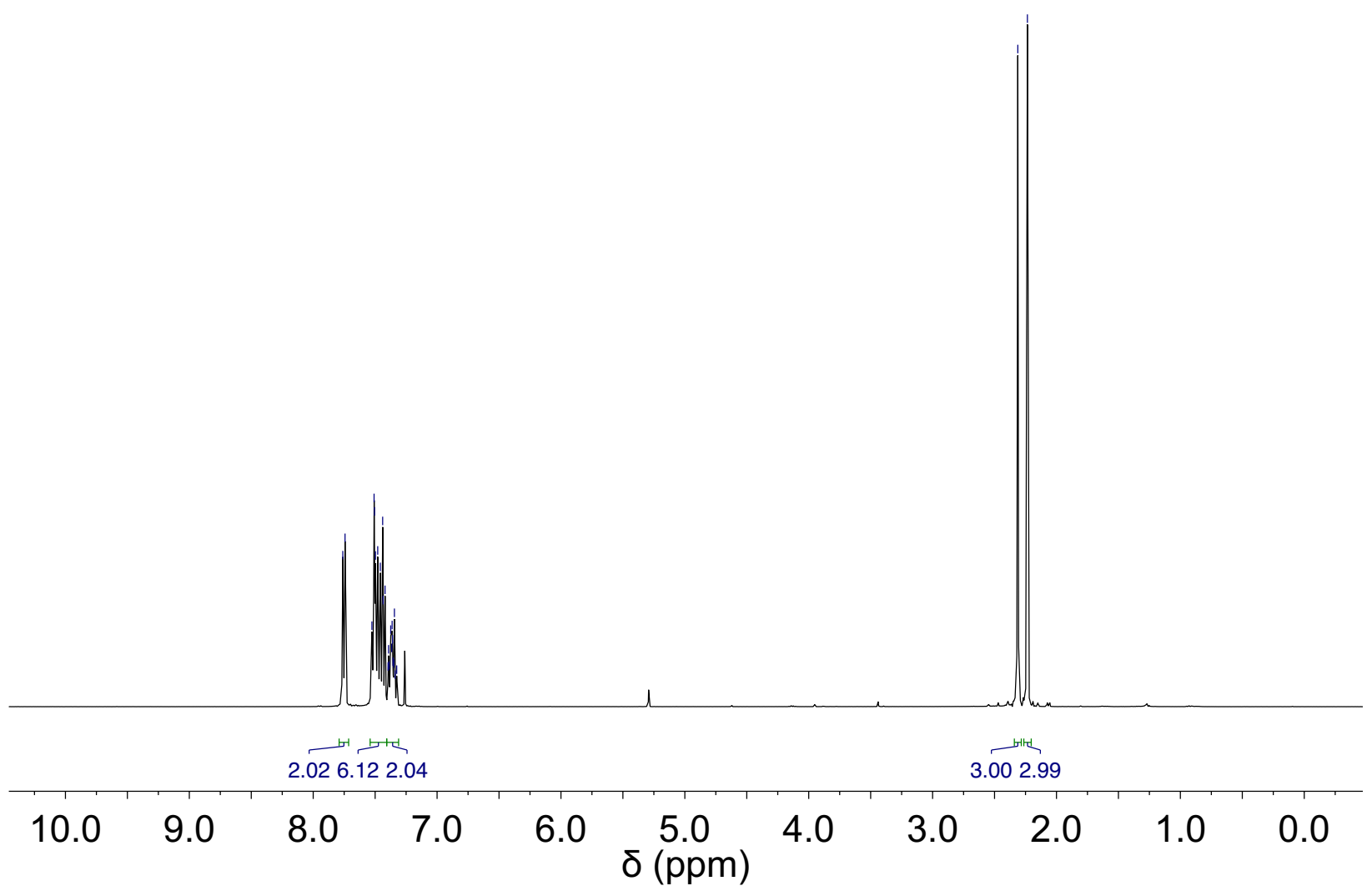

Figure S48. ${ }^{1} \mathrm{H}$ NMR spectrum of $1 \mathrm{i}$ in $\mathrm{CDCl}_{3}$. 


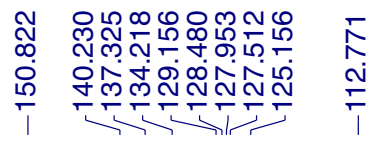

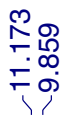

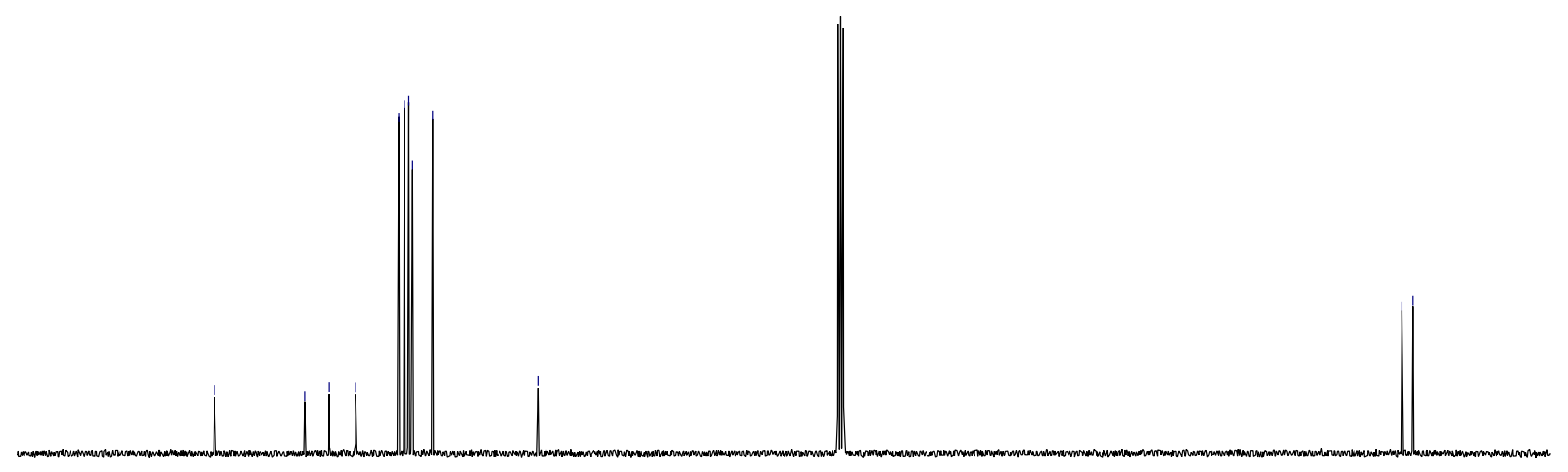

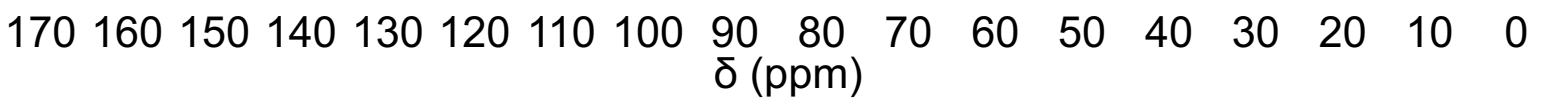

Figure S49. ${ }^{13} \mathrm{C}$ NMR spectrum of $1 \mathrm{i}$ in $\mathrm{CDCl}_{3}$.

1,3,4,5-tetraphenyl-1 $H$-pyrazole $(\mathbf{1} \mathbf{k})$

White solid. 42\% isolated yield. ${ }^{1} \mathbf{H}$ NMR (400 MHz, $\left.\mathbf{C D C l}_{3}\right): \delta 7.52(\mathrm{~m}, 2 \mathrm{H}, \mathrm{Ar}-\mathrm{H})$, $7.36-7.15(\mathrm{~m}, 14 \mathrm{H}, \mathrm{Ar}-H), 7.13-7.08(\mathrm{~m}, 2 \mathrm{H}, \mathrm{Ar}-H), 7.08-7.02(\mathrm{~m}, 2 \mathrm{H}, \mathrm{Ar}-H)$. ${ }^{13} \mathrm{C}$ NMR (101 MHz, CDCl $)$ : $\delta$ 150.34, 141.50, 140.10, 133.28, 133.25, 130.84, $130.56,130.22$, 128.89, 128.53, 128.39, 128.32 (2C), 128.26, 127.75, 127.33, $126.78,125.45,120.84$.

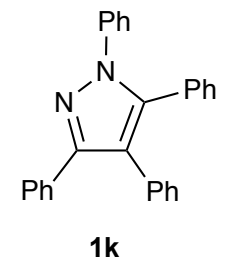




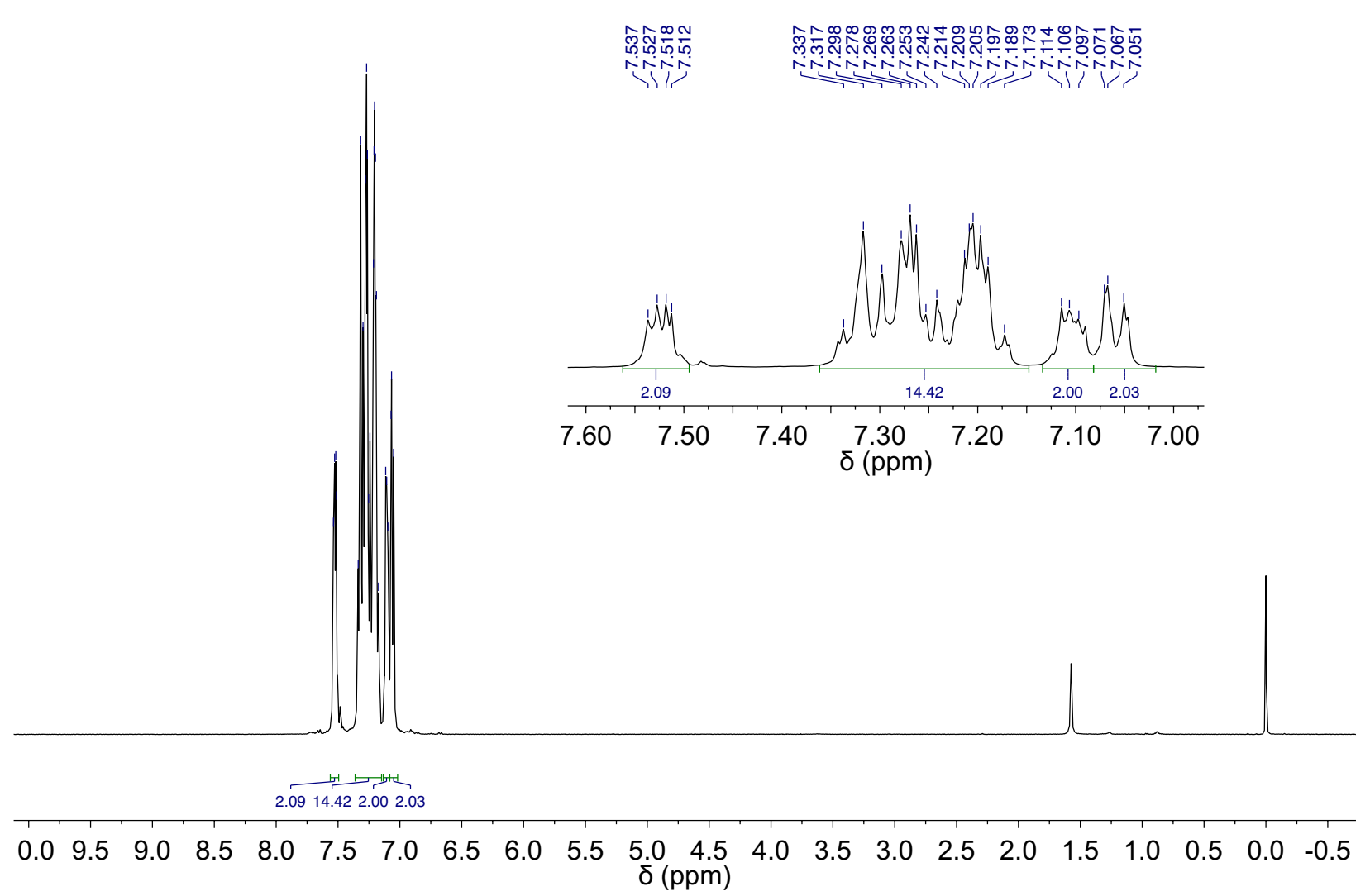

Figure S50. ${ }^{1} \mathrm{H}$ NMR spectrum of $1 \mathrm{k}$ in $\mathrm{CDCl}_{3}$, with inset showing a zoomed-in view of the aryl $(7.60$ $-7.00 \mathrm{ppm}$ ) region for clarity. 


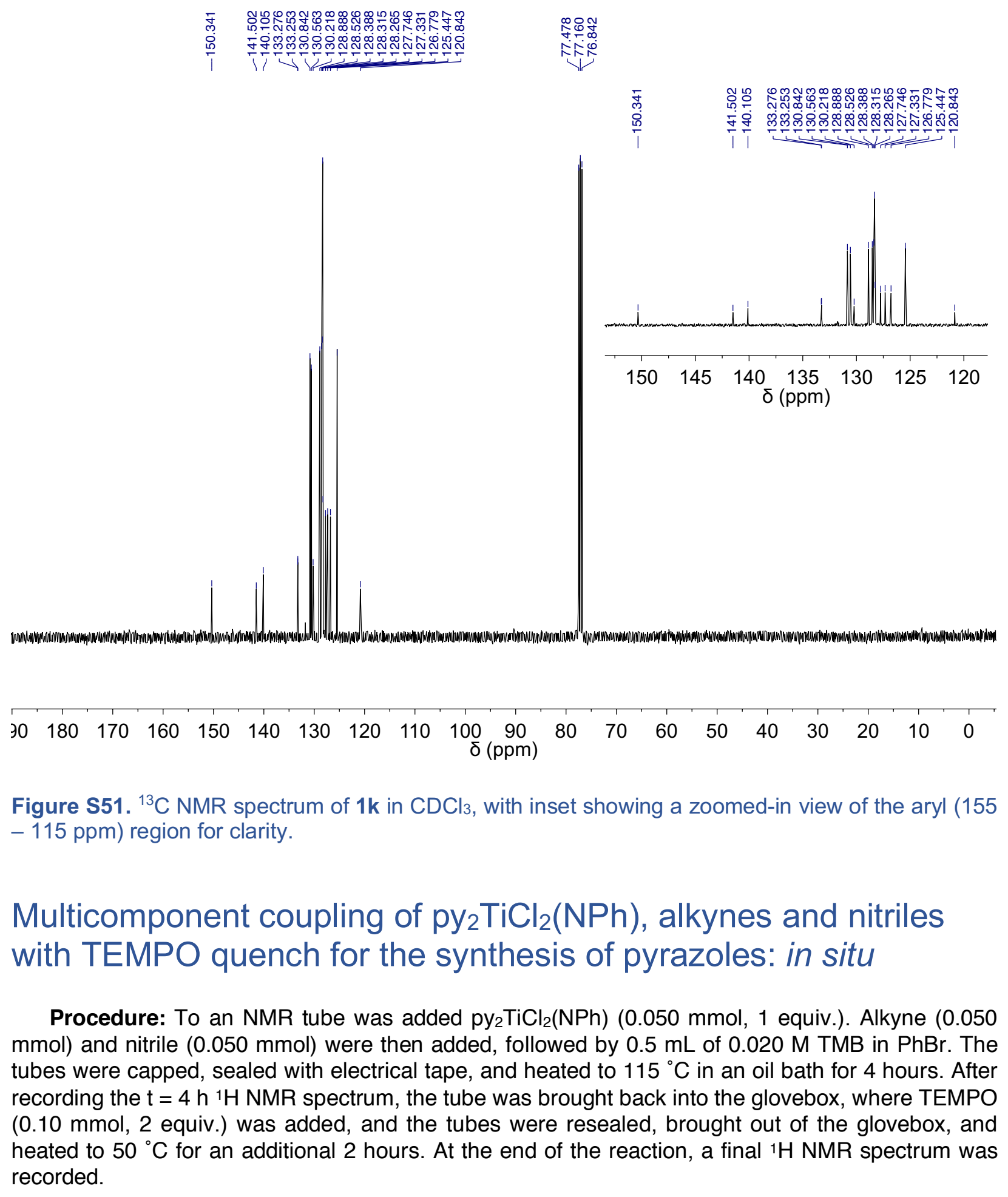


Table 2, Entry 1
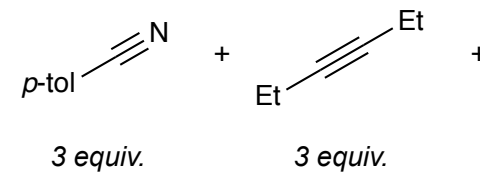

$+\mathrm{py}_{2} \mathrm{TiCl}_{2}(\mathrm{NPh})$

1 equiv.

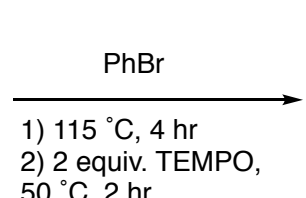

$50{ }^{\circ} \mathrm{C}, 2 \mathrm{hr}$

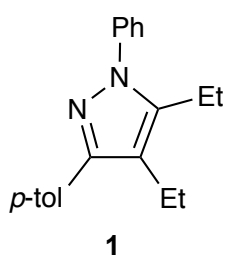

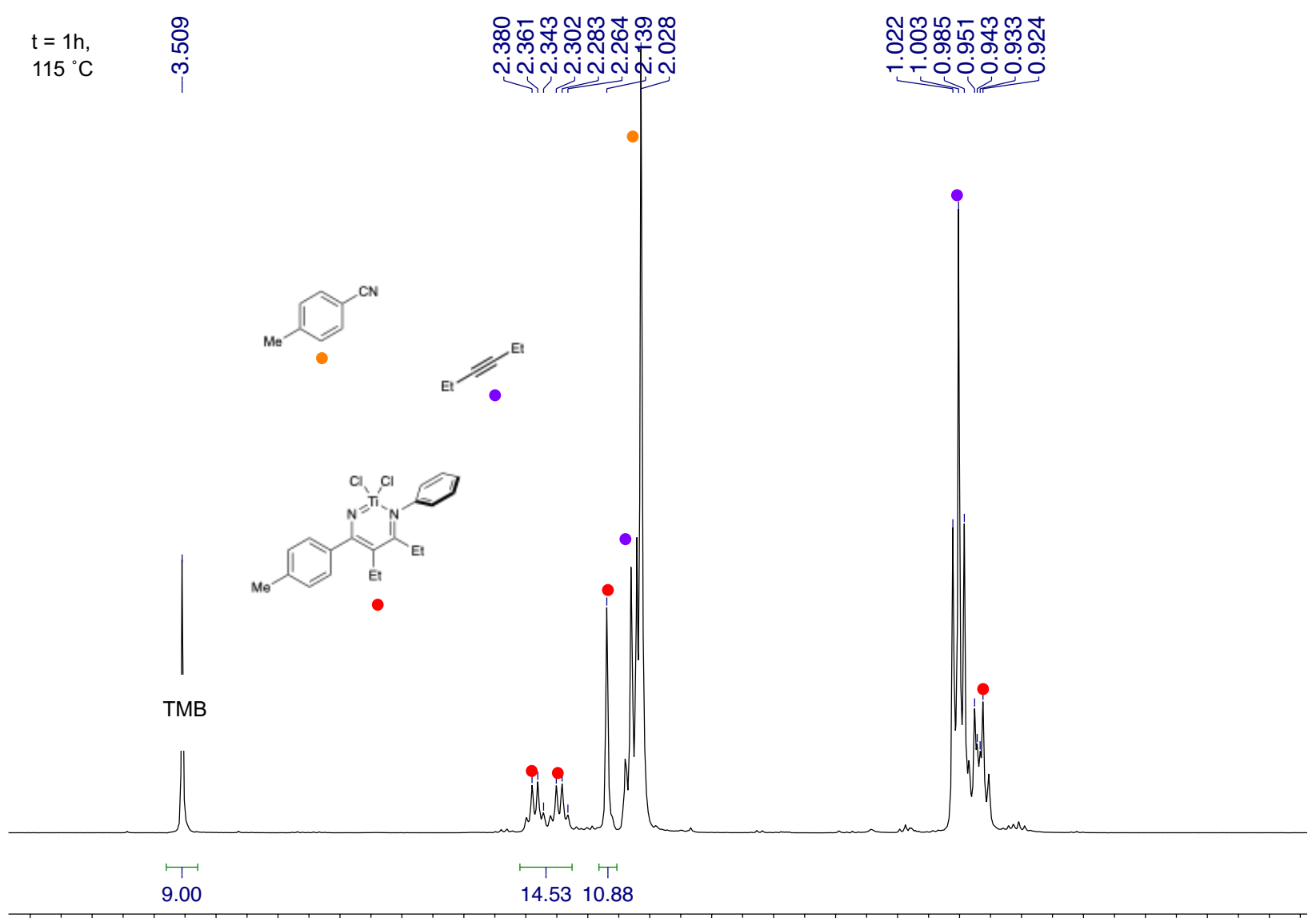

4.03 .83 .63 .43 .23 .02 .82 .62 .42 .22 .01 .81 .61 .41 .21 .00 .80 .60 .40 .20 .0 $\delta(\mathrm{ppm})$

Figure S52. $\mathrm{t}=1 \mathrm{~h}{ }^{1} \mathrm{H}$ NMR spectrum of multicomponent coupling of 3-hexyne (3 equiv.), $p$-tolunitrile (3 equiv.) and [py2 $\left.\mathrm{TiCl}_{2}(\mathrm{NPh})\right]_{2}$ in $\mathrm{PhBr}$. 


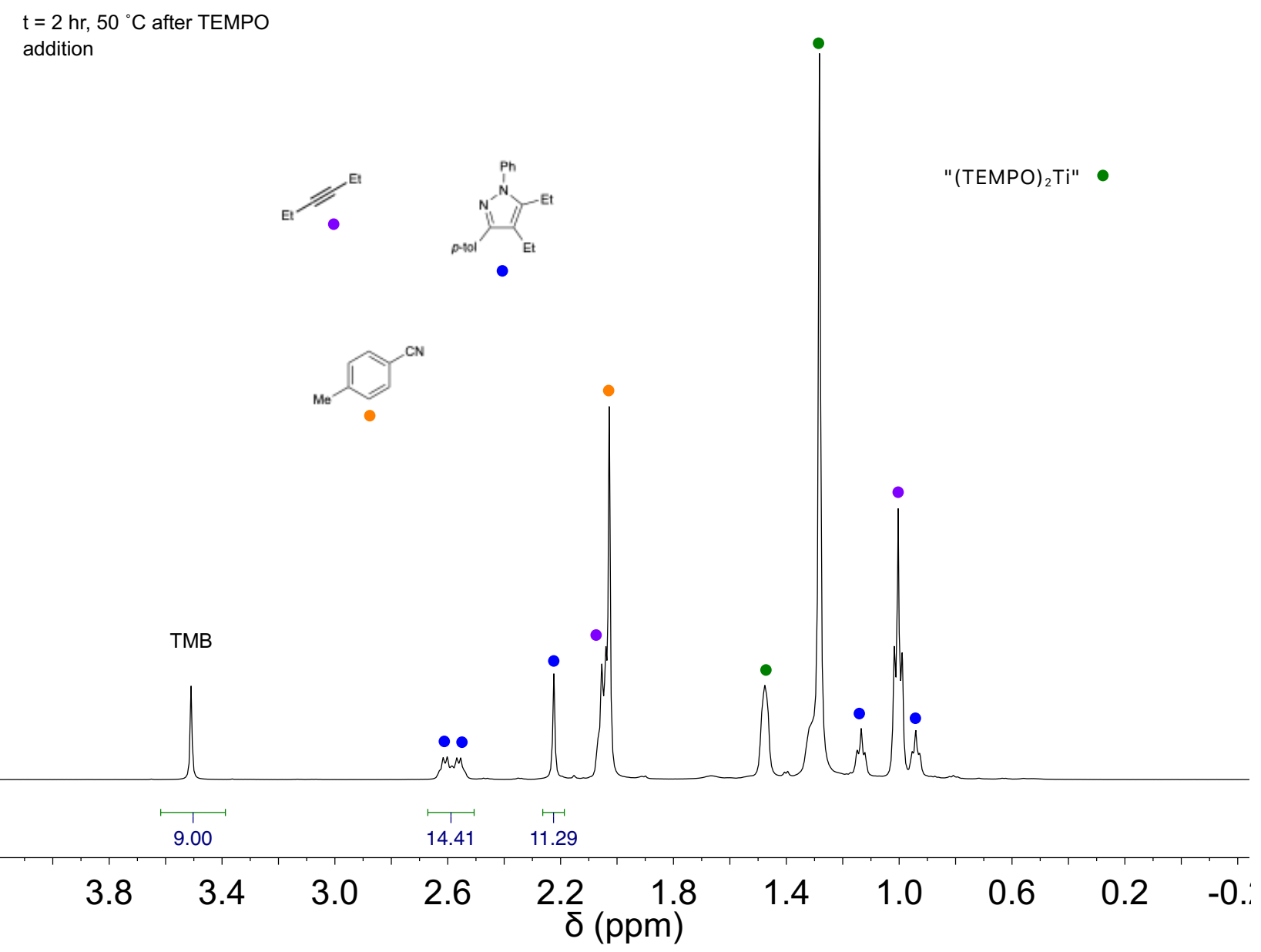

Figure S53. $\mathrm{t}=2 \mathrm{~h}^{1} \mathrm{H}$ NMR spectrum of multicomponent coupling of 3-hexyne (3 equiv.), p-tolunitrile (3 equiv.) and $\left[\mathrm{py}_{2} \mathrm{TiCl}_{2}(\mathrm{NPh})\right]_{2}$ in $\mathrm{PhBr}$ after TEMPO addition. 


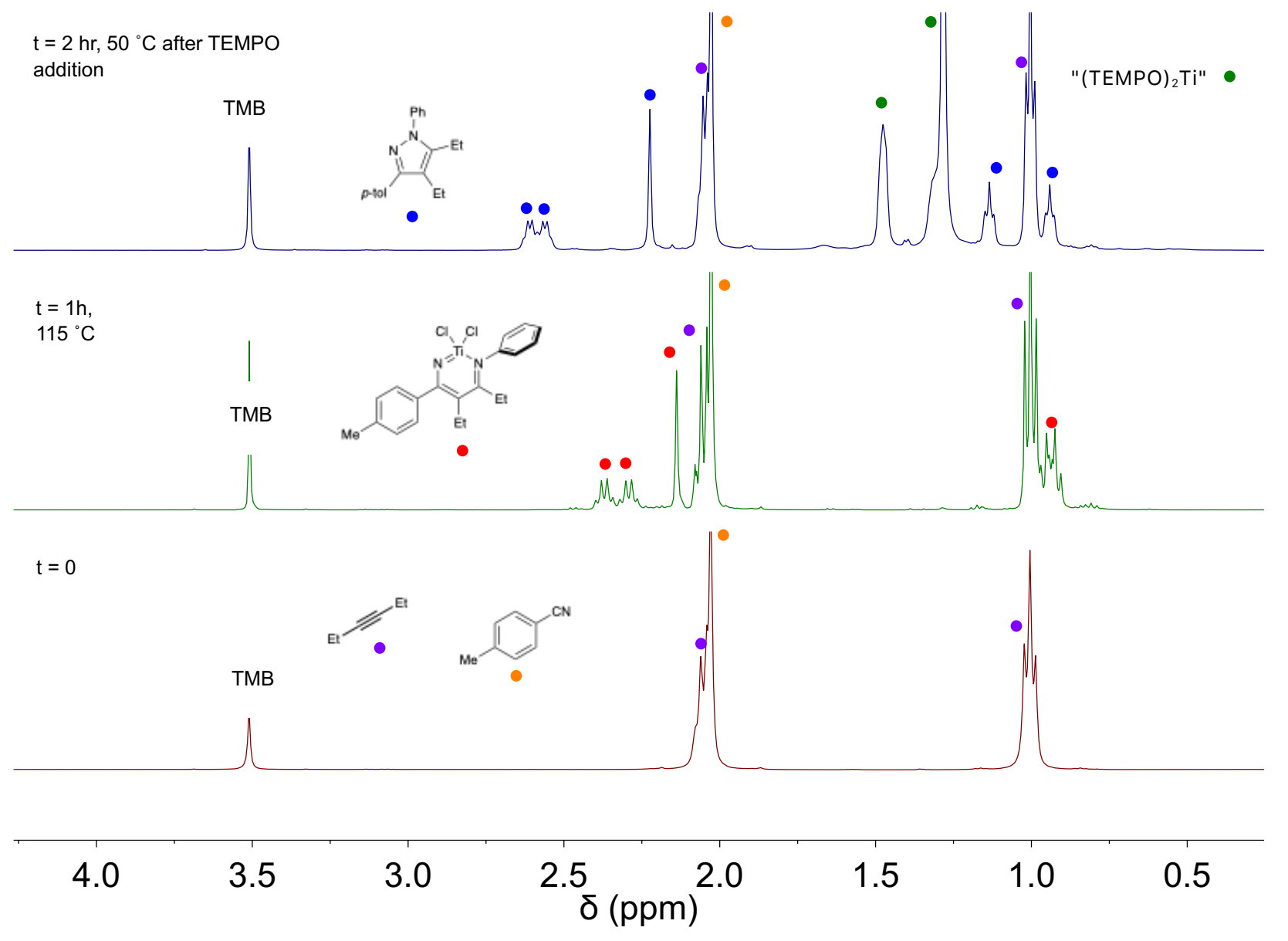

Figure S54. Stacked ${ }^{1} \mathrm{H}$ NMR spectra characterizing the multicomponent coupling of 3-hexyne (3 equiv.), $p$-tolunitrile (3 equiv.) and $\left[\mathrm{py}_{2} \mathrm{TiCl}_{2}(\mathrm{NPh})\right]_{2}$ in $\mathrm{PhBr}$. Bottom (red trace): $\mathrm{t}=0$. Middle (green trace): $\mathrm{t}=1 \mathrm{~h}$ at $115{ }^{\circ} \mathrm{C}$ generating metallacycle analogous to 7 , prior to TEMPO addition. Top (blue trace): $\mathrm{t}=2 \mathrm{~h}$ after TEMPO addition to give pyrazole 1 .

Table 2, Entry 2

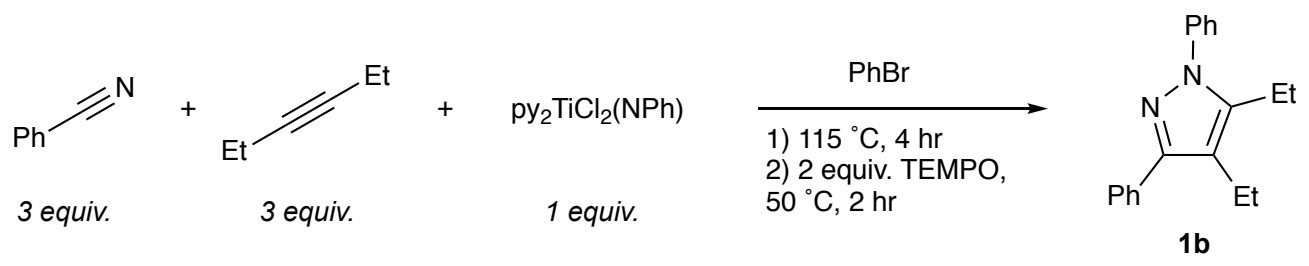




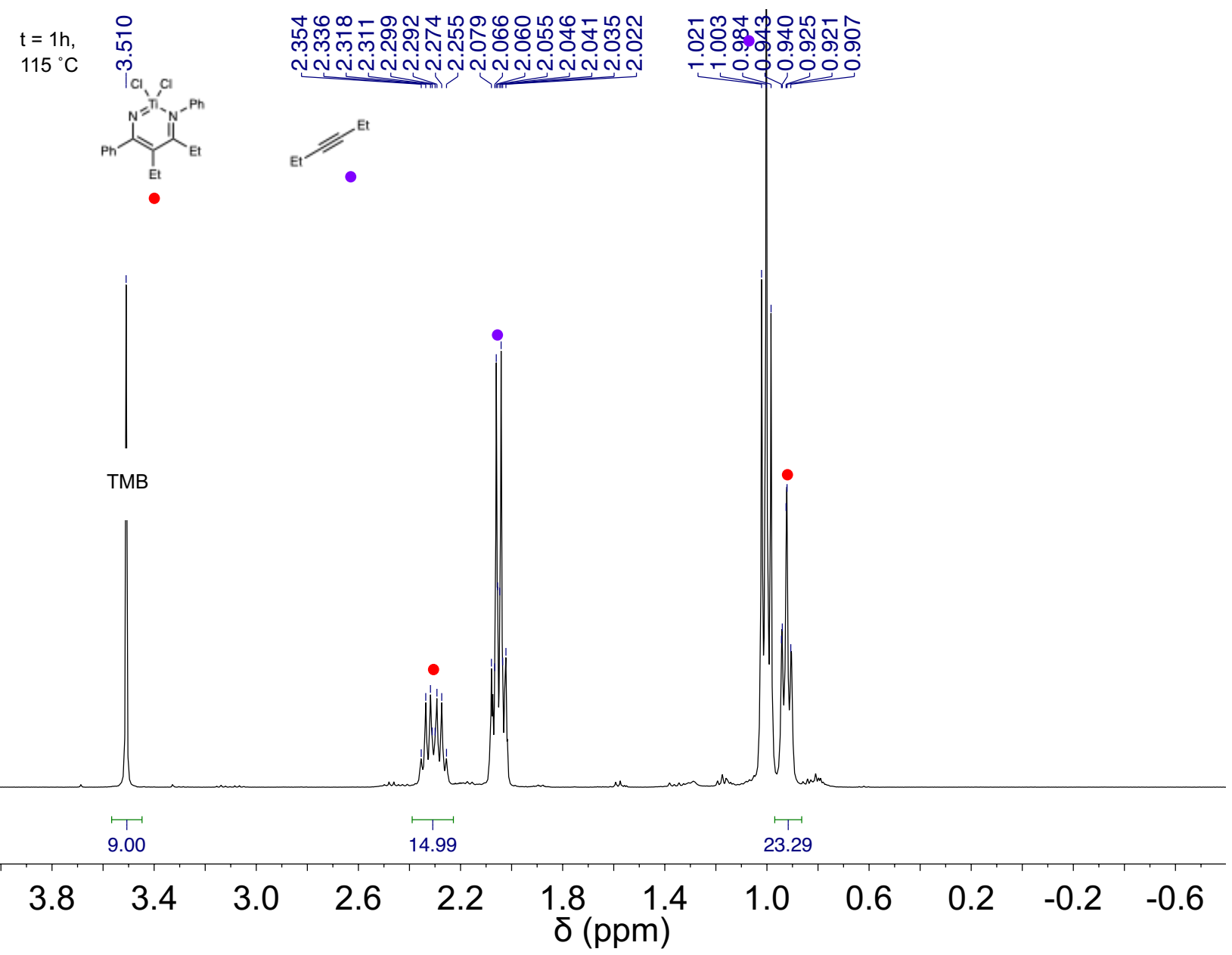

Figure S55. $\mathrm{t}=1 \mathrm{~h}{ }^{1} \mathrm{H}$ NMR spectrum of multicomponent coupling of 3-hexyne (3 equiv.), benzonitrile (3 equiv.) and $\left[\mathrm{py}_{2} \mathrm{TiCl}_{2}(\mathrm{NPh})\right]_{2}$ in $\mathrm{PhBr}$. 


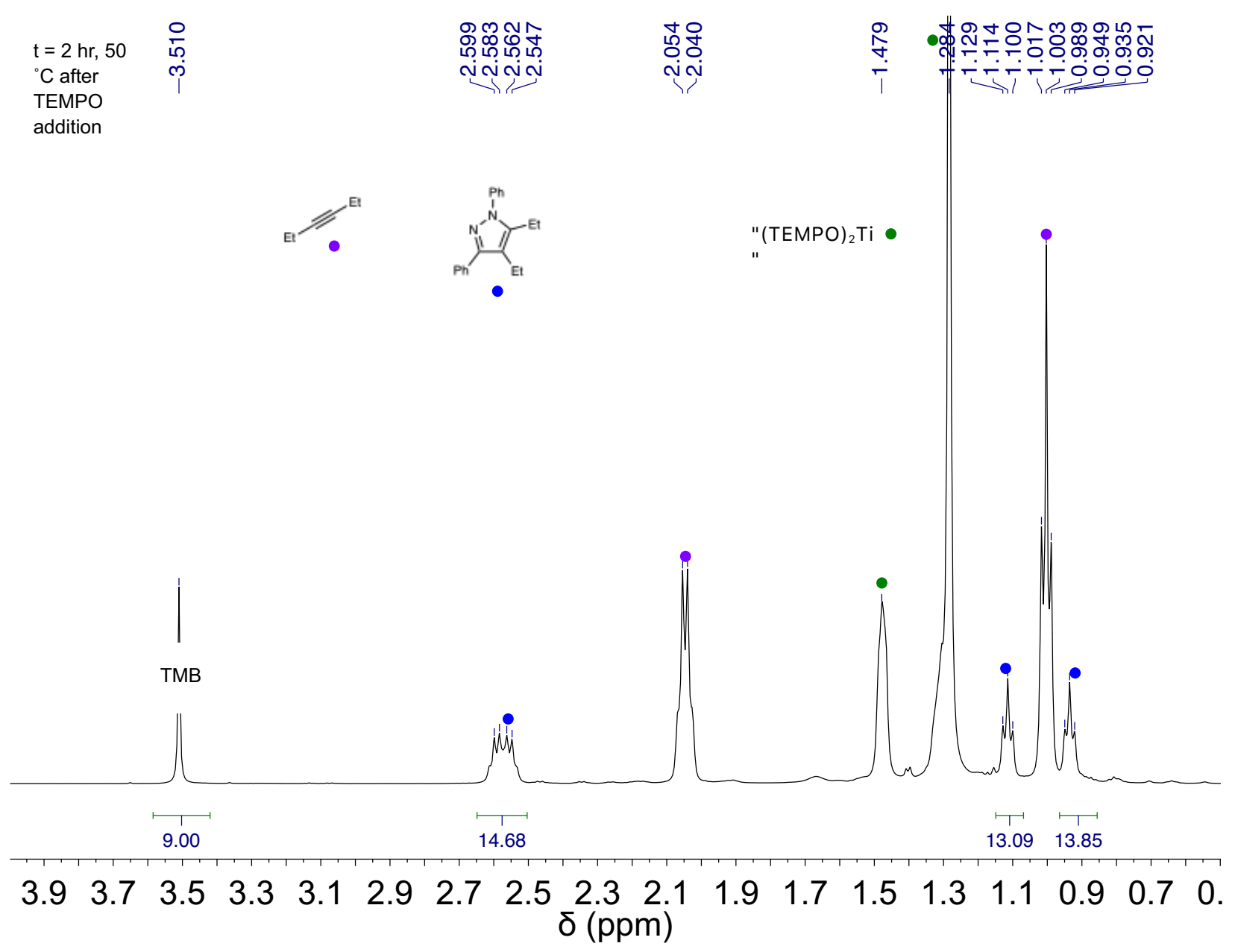

Figure S56. $\mathrm{t}=2 \mathrm{~h}{ }^{1} \mathrm{H}$ NMR spectrum of multicomponent coupling of 3-hexyne (3 equiv.), benzonitrile (3 equiv.) and $\left[\mathrm{py}_{2} \mathrm{TiCl}_{2}(\mathrm{NPh})\right]_{2}$ in $\mathrm{PhBr}$ after TEMPO addition. 

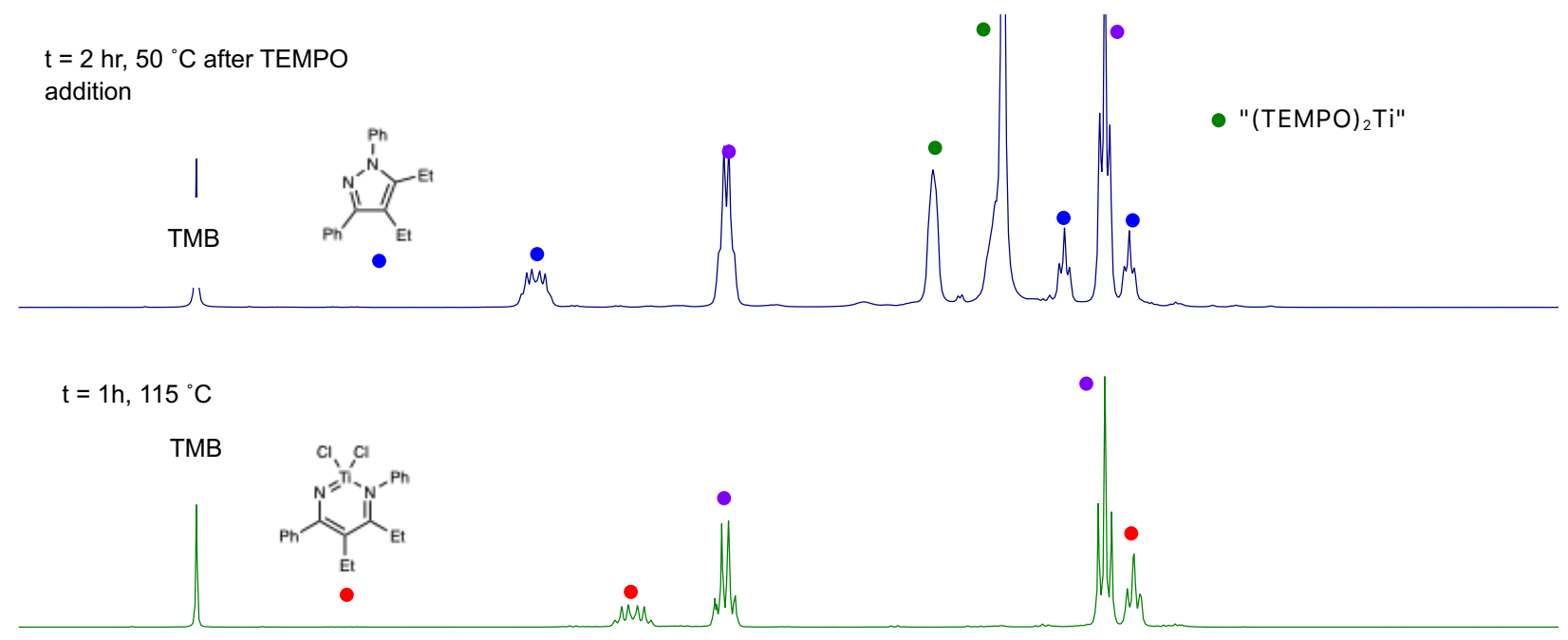

$$
t=0
$$
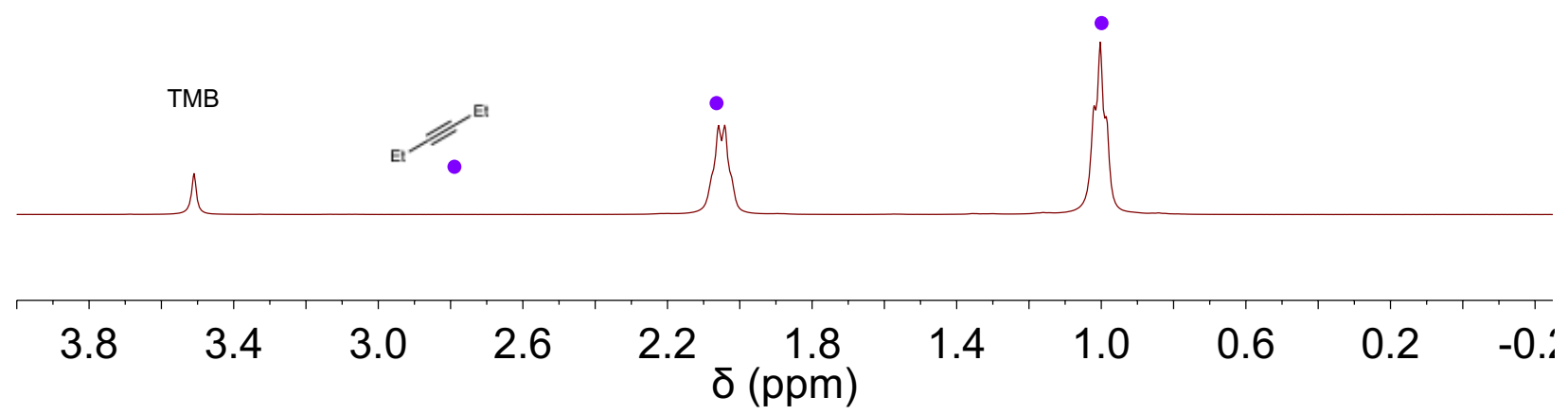

Figure S57. Stacked ${ }^{1} \mathrm{H}$ NMR spectra characterizing the multicomponent coupling of 3-hexyne (3 equiv.), benzonitrile (3 equiv.) and $\left[\mathrm{py}_{2} \mathrm{TiCl}_{2}(\mathrm{NPh})\right]_{2}$ in $\mathrm{PhBr}$. Bottom (red trace): $\mathrm{t}=0$. Middle (green trace): $\mathrm{t}=1 \mathrm{~h}$ at $115^{\circ} \mathrm{C}$ generating metallacycle analogous to 7 , prior to TEMPO addition. Top (blue trace): $\mathrm{t}=\mathbf{2} \mathrm{h}$ after TEMPO addition to give pyrazole $\mathbf{1 b}$.

Table 2, Entry 3
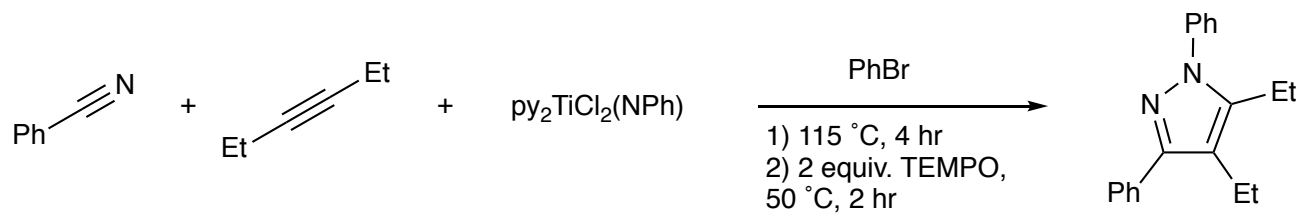

$1 b$ 


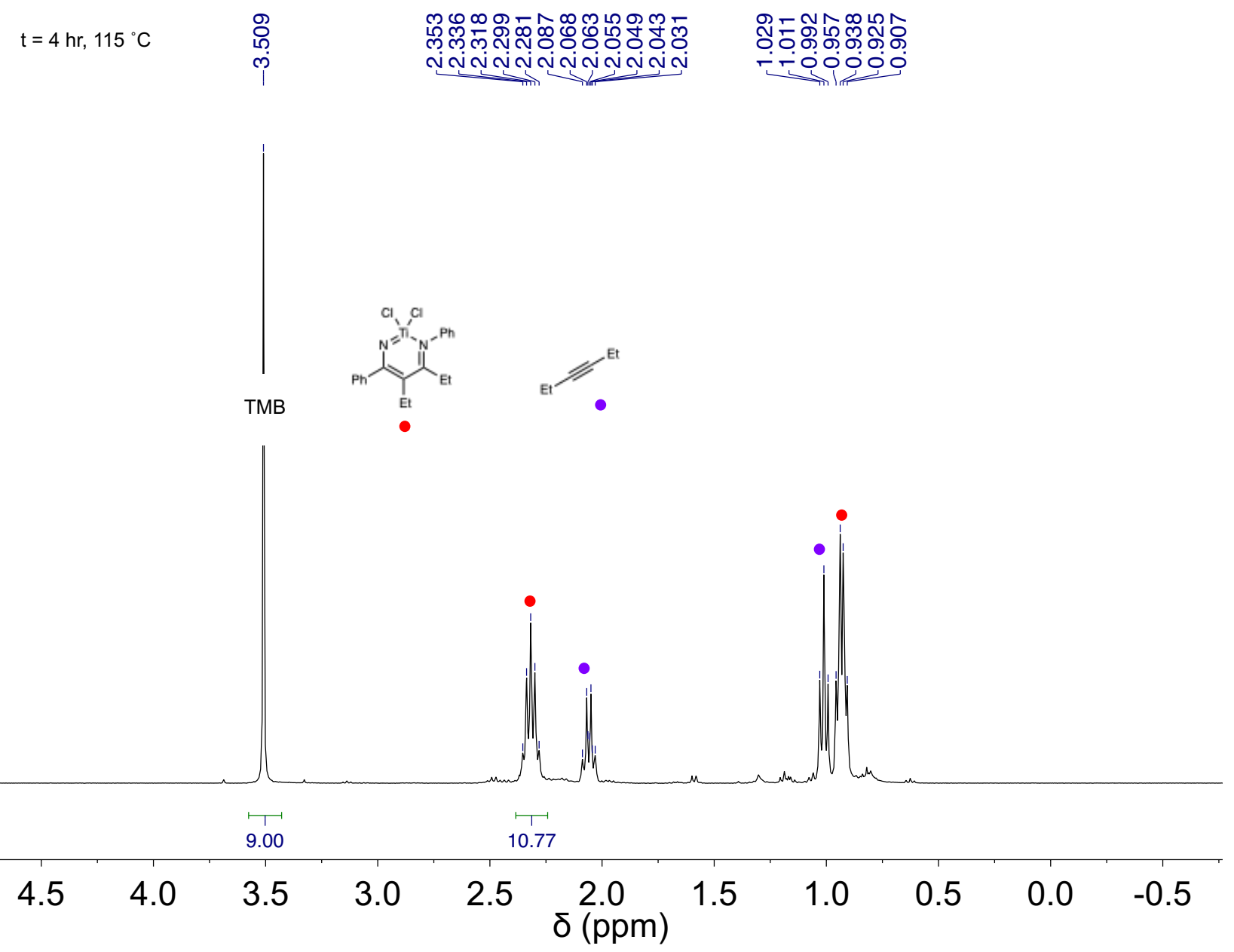

Figure S58. $\mathrm{t}=4 \mathrm{~h}{ }^{1} \mathrm{H}$ NMR spectrum of multicomponent coupling of 3-hexyne, benzonitrile and [py2 $\left.\mathrm{TiCl}_{2}(\mathrm{NPh})\right]_{2}$ in $\mathrm{PhBr}$. 


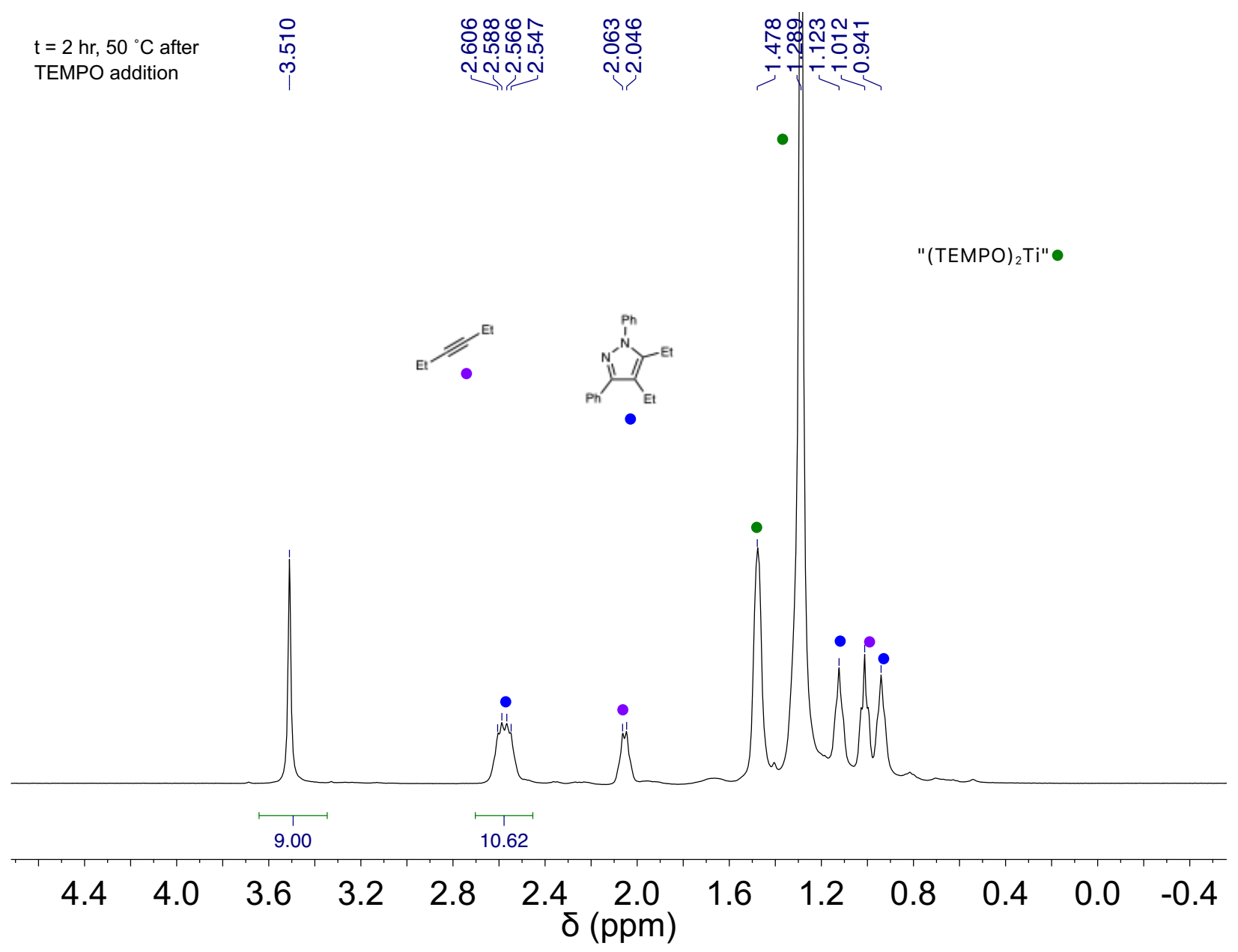

Figure S59. $\mathrm{t}=2 \mathrm{~h}{ }^{1} \mathrm{H}$ NMR spectrum of multicomponent coupling of 3-hexyne, benzonitrile and $\left[\mathrm{py}_{2} \mathrm{TiCl}_{2}(\mathrm{NPh})\right]_{2}$ in $\mathrm{PhBr}$ after TEMPO addition. 


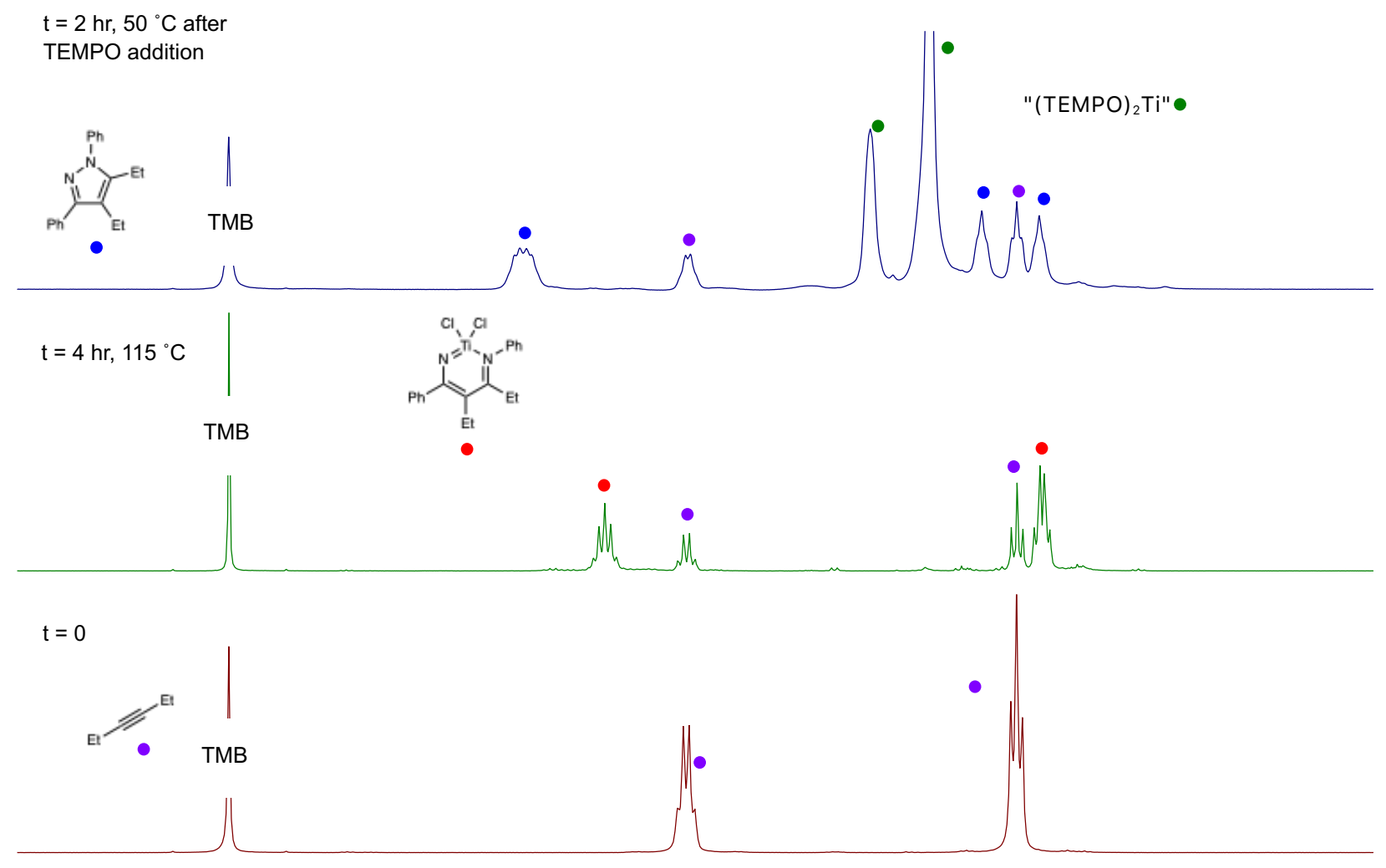

\subsection{3 .83 .63 .43 .23 .02 .82 .62 .42 .22 .01 .81 .61 .41 .21 .00 .80 .60 .40 .20 .0 $\delta(\mathrm{ppm})$}

Figure S60. Stacked ${ }^{1} \mathrm{H}$ NMR spectra characterizing the multicomponent coupling of 3-hexyne, benzonitrile and $\left[\mathrm{py}_{2} \mathrm{TiCl}_{2}(\mathrm{NPh})\right]_{2}$ in $\mathrm{PhBr}$. Bottom (red trace): $\mathrm{t}=0$. Middle (green trace): $\mathrm{t}=4 \mathrm{~h}$ at 115 ${ }^{\circ} \mathrm{C}$ generating metallacycle analogous to 7, prior to TEMPO addition. Top (blue trace): $\mathrm{t}=2 \mathrm{~h}$ after TEMPO addition to give pyrazole $\mathbf{1 b}$.

Table 2, Entry 4

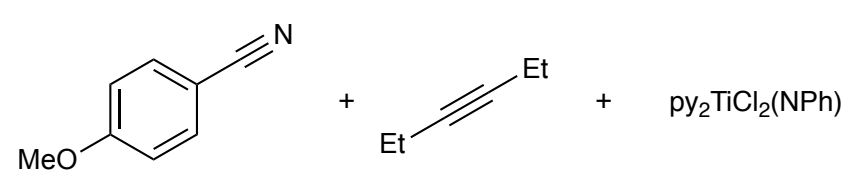<smiles>CCc1c(-c2ccc(OC)cc2)nn(-c2ccccc2)c1CC</smiles> 


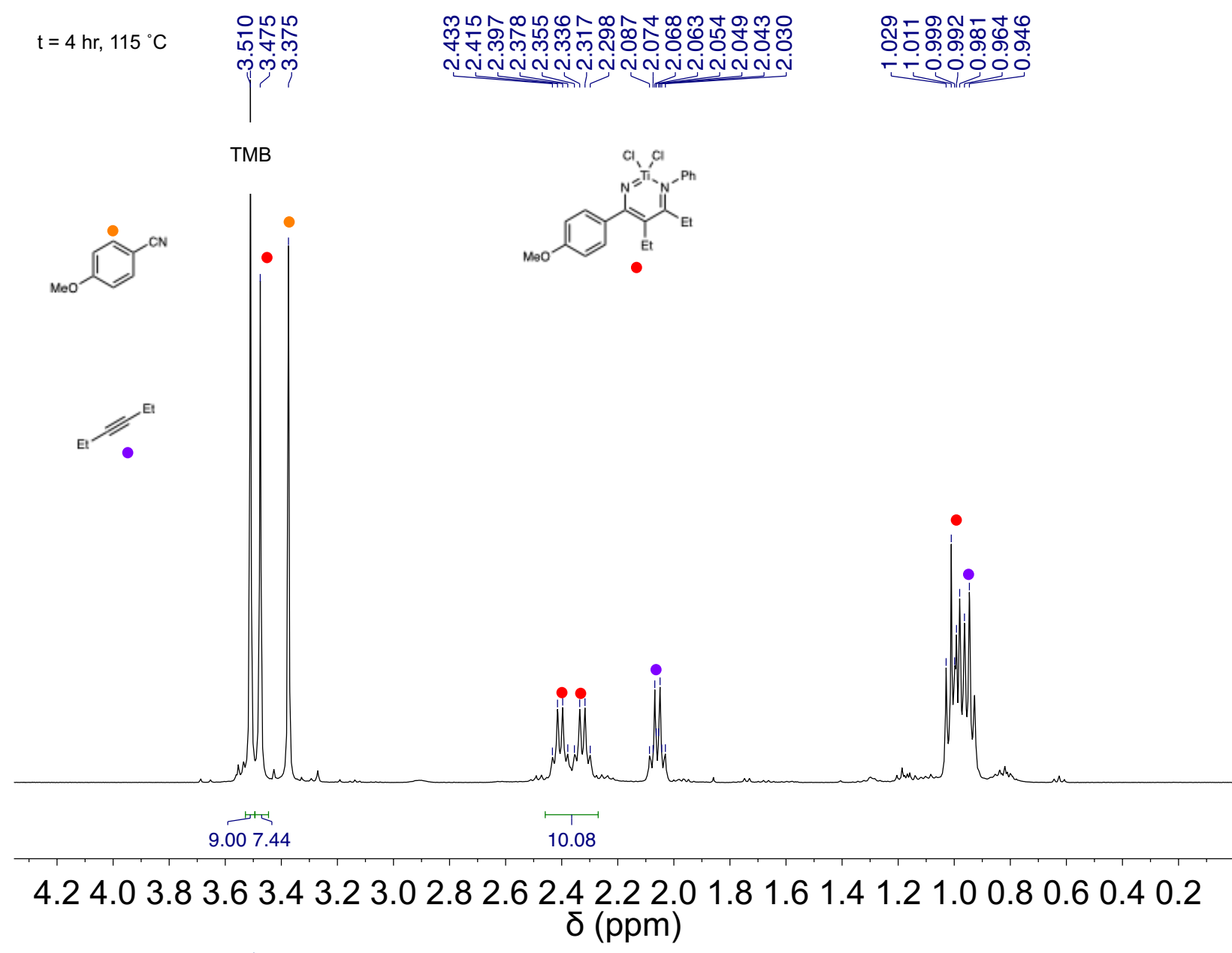

Figure S61. $\mathrm{t}=4 \mathrm{~h}{ }^{1} \mathrm{H}$ NMR spectrum of multicomponent coupling of 3-hexyne, 4-methoxybenzonitrile and $\left[\mathrm{py}_{2} \mathrm{TiCl}_{2}(\mathrm{NPh})\right]_{2}$ in $\mathrm{PhBr}$. 


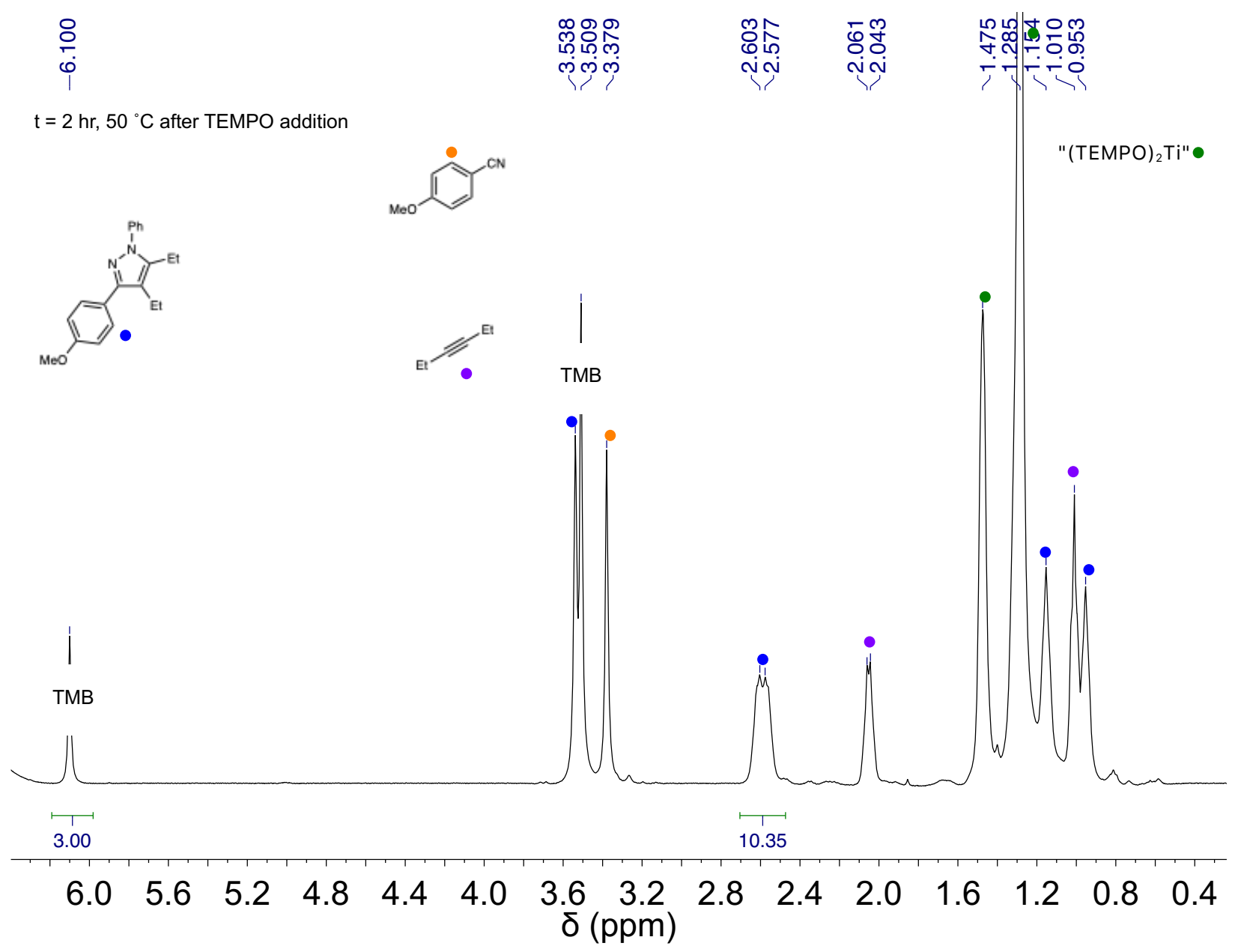

Figure S62. $\mathrm{t}=4 \mathrm{~h}{ }^{1} \mathrm{H}$ NMR spectrum of multicomponent coupling of 3-hexyne, 4-methoxybenzonitrile and $\left[\mathrm{py}_{2} \mathrm{TiCl}_{2}(\mathrm{NPh})\right]_{2}$ in $\mathrm{PhBr}$ after TEMPO addition. 

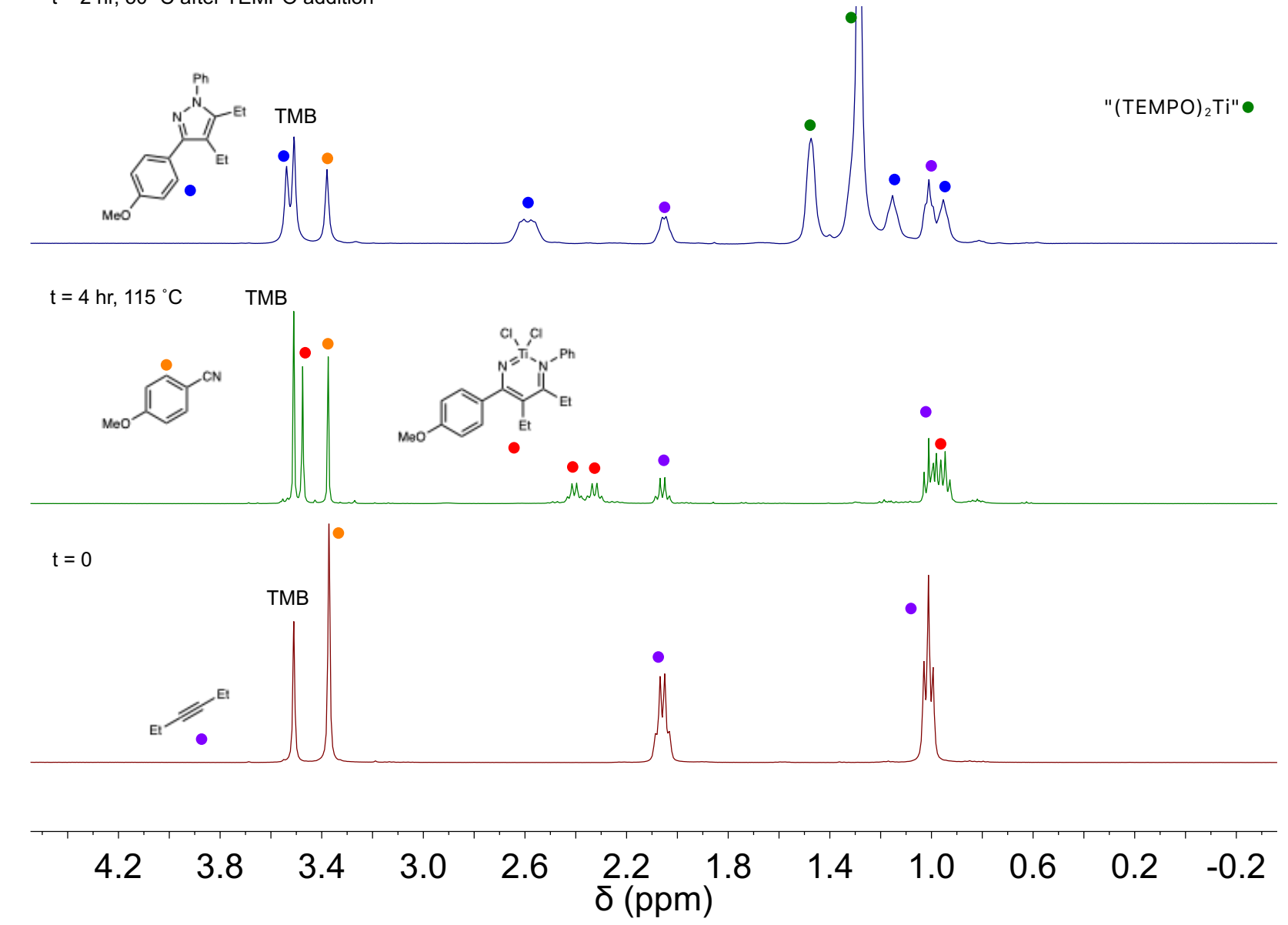

Figure S63. Stacked ${ }^{1} \mathrm{H}$ NMR spectra characterizing the multicomponent coupling of 3-hexyne, 4methoxybenzonitrile and $\left[\mathrm{py}_{2} \mathrm{TiCl}_{2}(\mathrm{NPh})\right]_{2}$ in $\mathrm{PhBr}$. Bottom (red trace): $\mathrm{t}=0$. Middle (green trace): $\mathrm{t}=$ $4 \mathrm{~h}$ at $115^{\circ} \mathrm{C}$ generating metallacycle analogous to 7 , prior to TEMPO addition. Top (blue trace): $\mathrm{t}=2$ $\mathrm{h}$ after TEMPO addition to give pyrazole $1 \mathrm{c}$.

Table 2, Entry 5<smiles>[C+]C#CC#CCC</smiles><smiles>CCc1c(-c2ccc(C(F)(F)F)cc2)nn(-c2ccccc2)c1CC</smiles> 


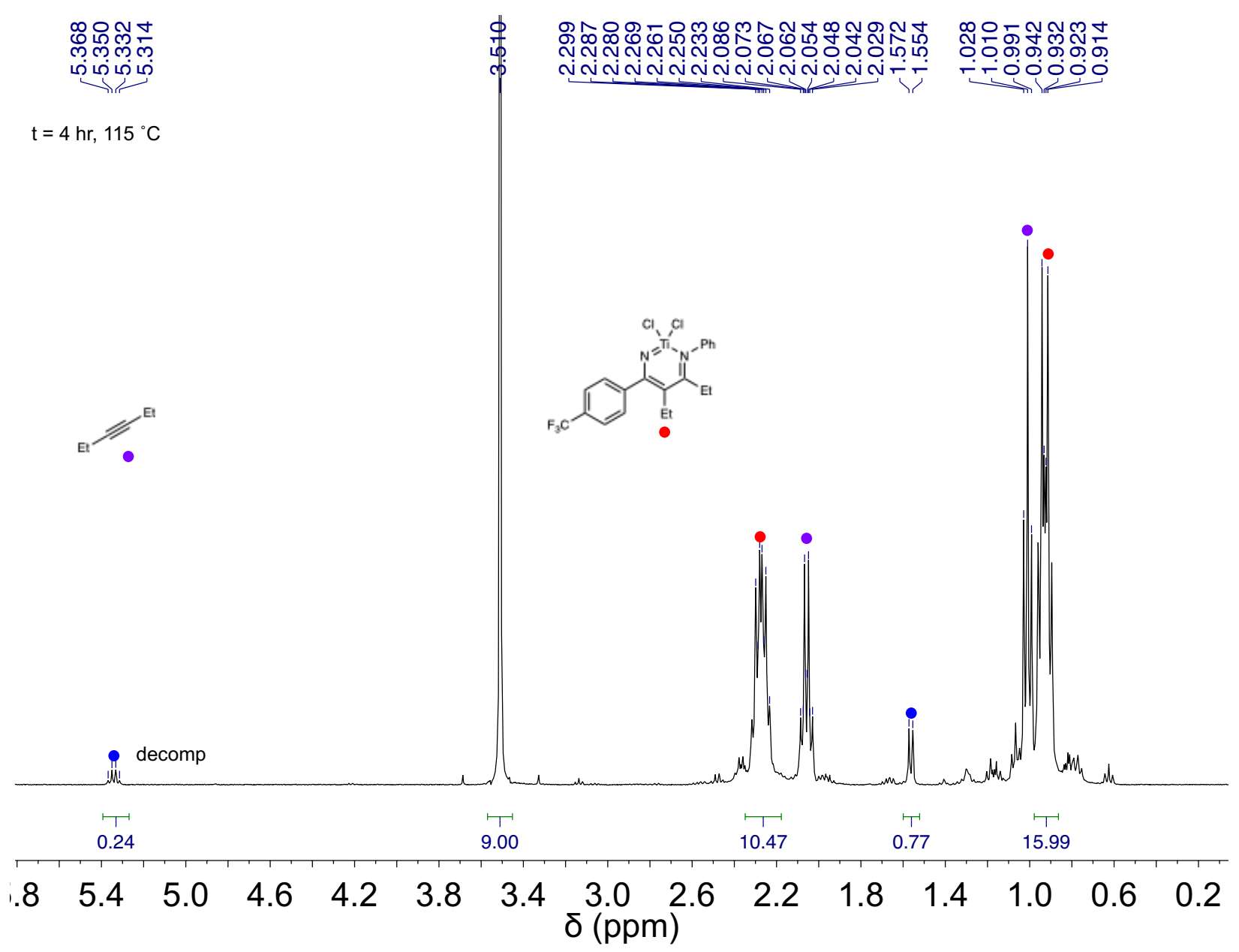

Figure S64. $\mathrm{t}=4 \mathrm{~h}{ }^{1} \mathrm{H}$ NMR spectrum of multicomponent coupling of 3-hexyne, 4(trifluoromethyl)benzonitrile and $\left[\mathrm{py}_{2} \mathrm{TiCl}_{2}(\mathrm{NPh})\right]_{2}$ in $\mathrm{PhBr}$. 


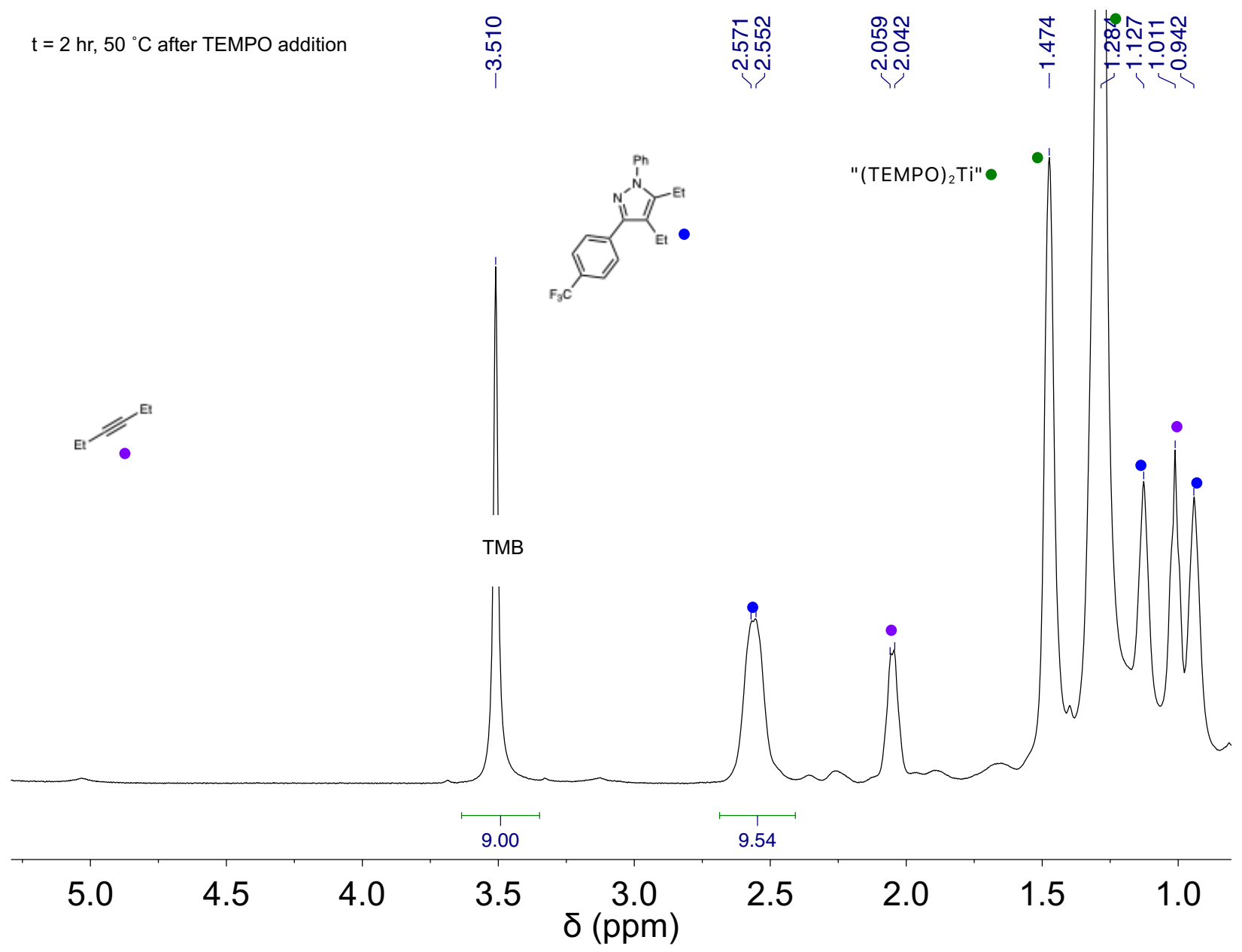

Figure S65. $\mathrm{t}=2 \mathrm{~h}{ }^{1} \mathrm{H}$ NMR spectrum of multicomponent coupling of 3-hexyne, 4(trifluoromethyl)benzonitrile and $\left[\mathrm{py}_{2} \mathrm{TiCl}_{2}(\mathrm{NPh})\right]_{2}$ in $\mathrm{PhBr}$ after TEMPO addition. 


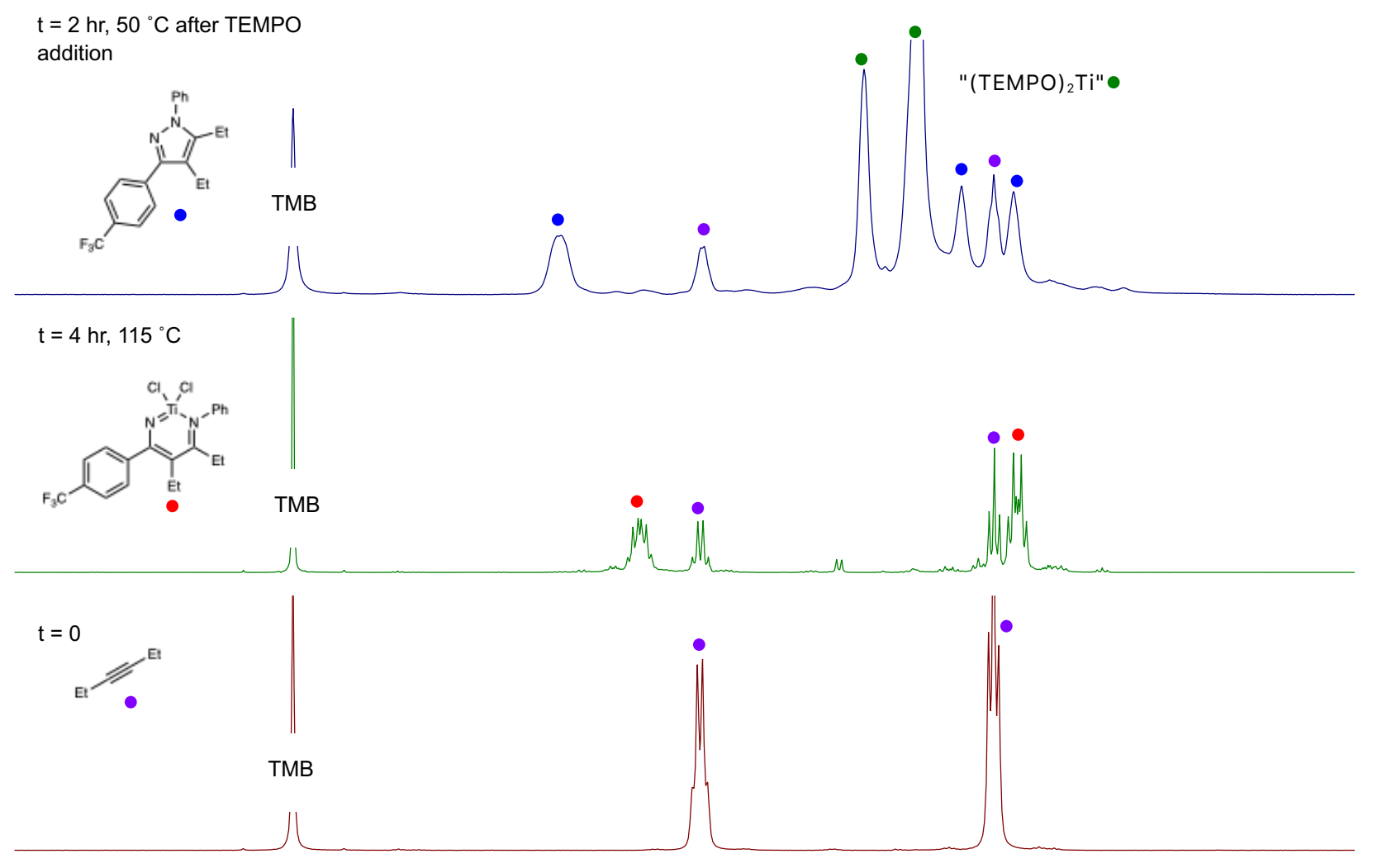

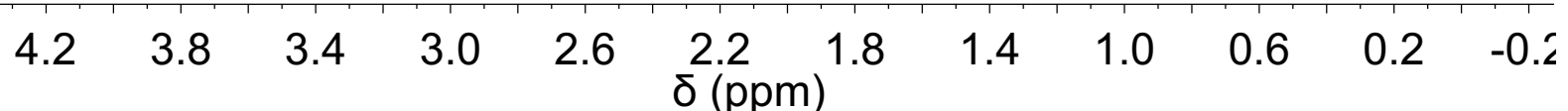

Figure S66. Stacked ${ }^{1} \mathrm{H}$ NMR spectra characterizing the multicomponent coupling of 3-hexyne, 4trifluoromethylbenzonitrile and $\left[\mathrm{py}_{2} \mathrm{TiCl}_{2}(\mathrm{NPh})\right]_{2}$ in $\mathrm{PhBr}$. Bottom (red trace): $\mathrm{t}=0$. Middle (green trace): $\mathrm{t}=4 \mathrm{~h}$ at $115^{\circ} \mathrm{C}$ generating metallacycle analogous to 7 , prior to TEMPO addition. Top (blue trace): $\mathrm{t}$ $=2 \mathrm{~h}$ after TEMPO addition to give pyrazole $1 \mathrm{~d}$.

Table 2, Entry 6

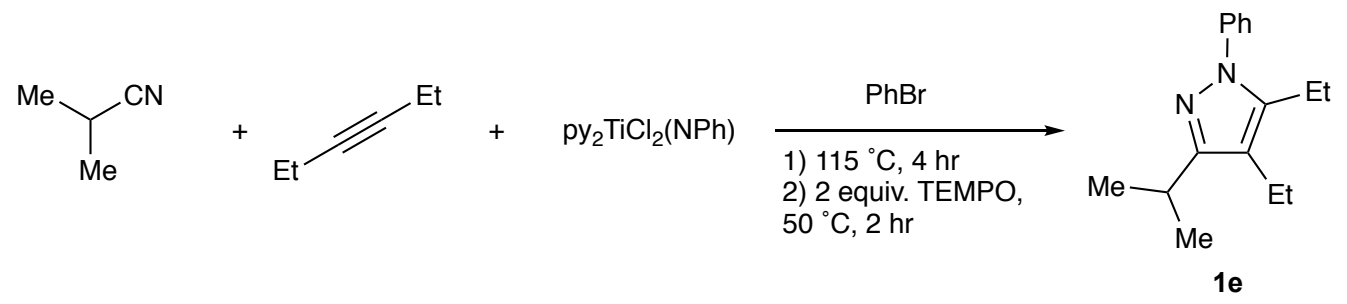




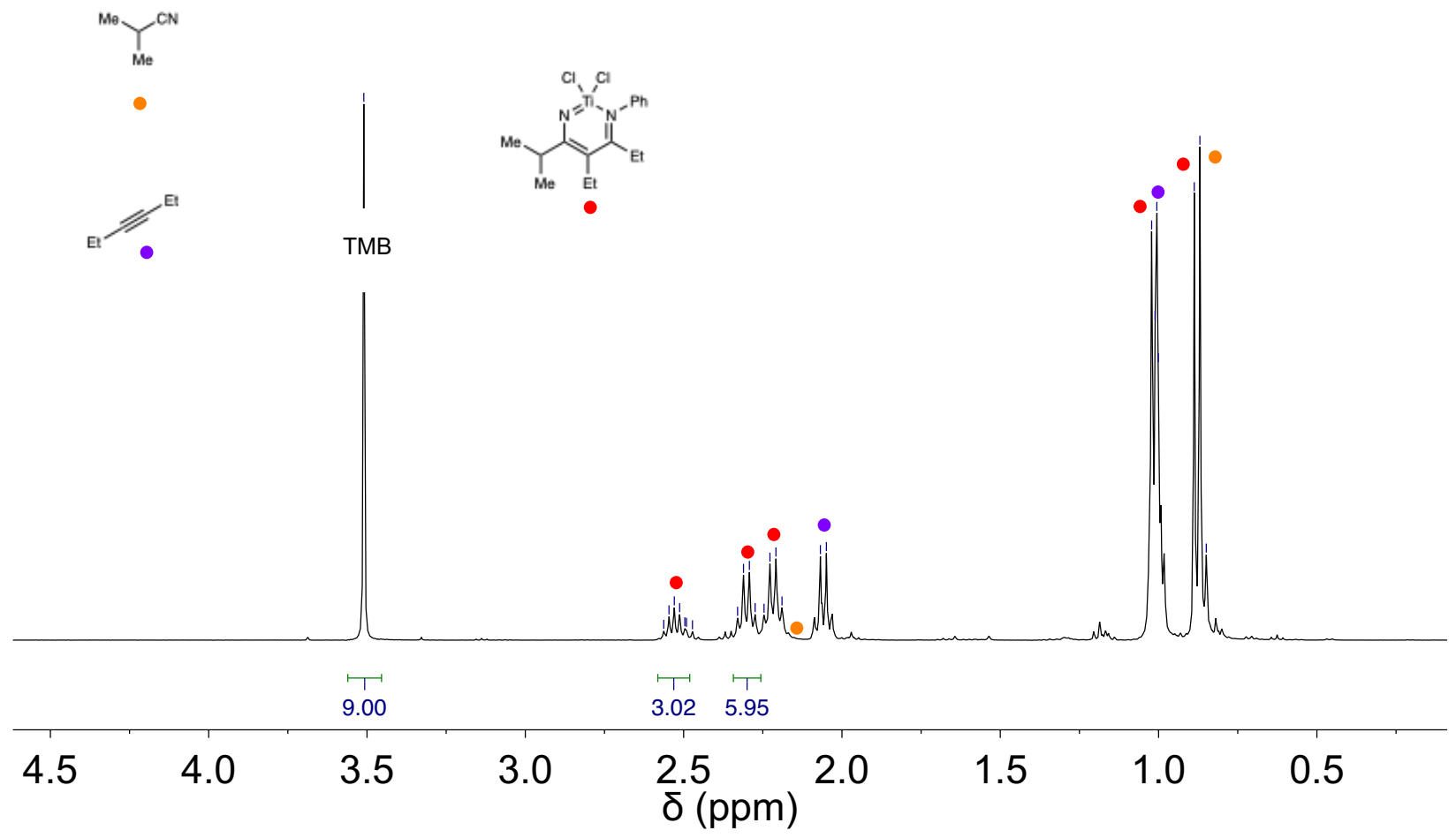

Figure S67. $\mathrm{t}=4 \mathrm{~h}{ }^{1} \mathrm{H}$ NMR spectrum of multicomponent coupling of 3-hexyne, isobutyronitrile and [py2 $\left.\mathrm{TiCl}_{2}(\mathrm{NPh})\right]_{2}$ in $\mathrm{PhBr}$. 


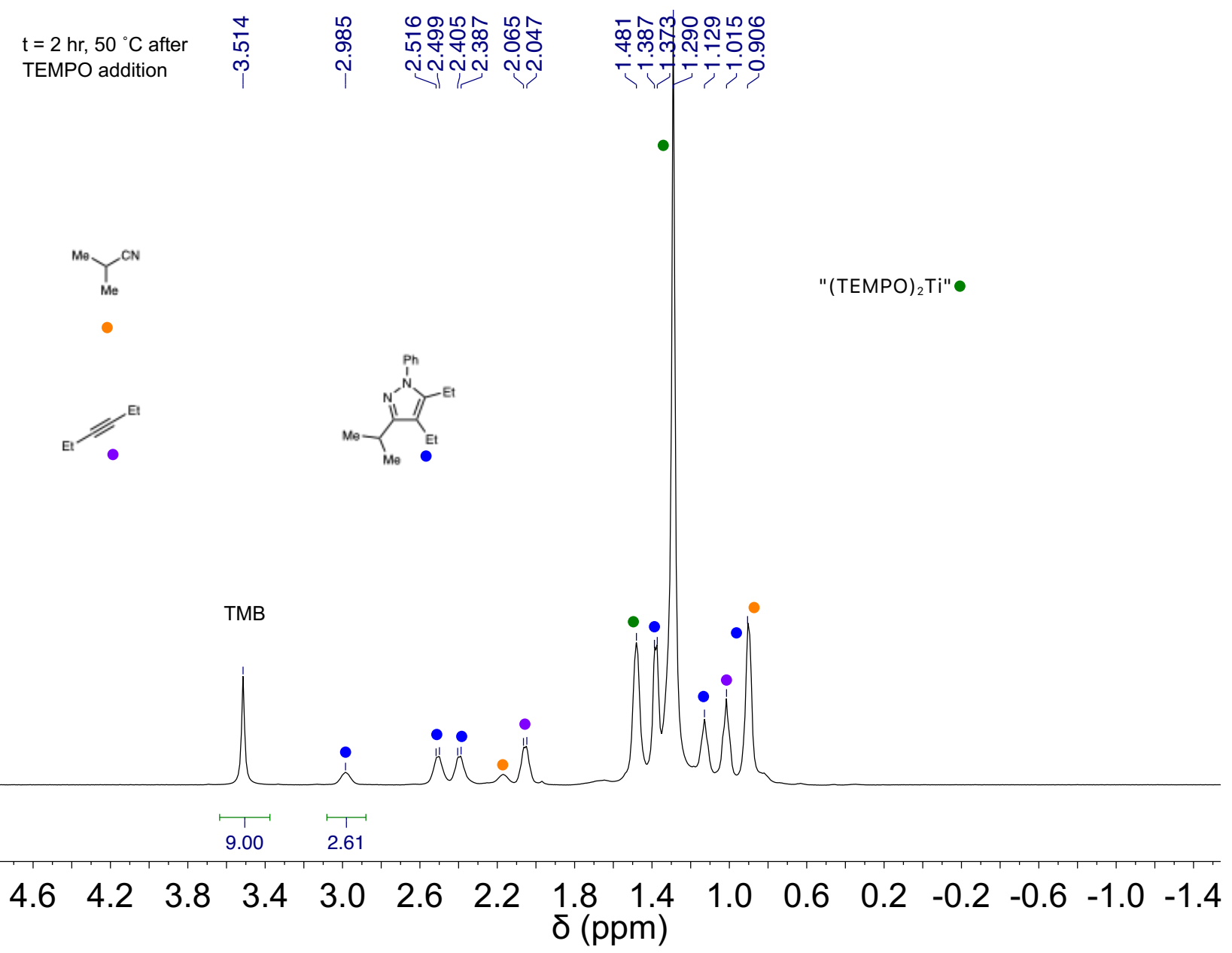

Figure S68. $\mathrm{t}=2 \mathrm{~h}{ }^{1} \mathrm{H}$ NMR spectrum of multicomponent coupling of 3-hexyne, isobutyronitrile and $\left[\mathrm{py}_{2} \mathrm{TiCl}_{2}(\mathrm{NPh})\right]_{2}$ in $\mathrm{PhBr}$ after TEMPO addition. 

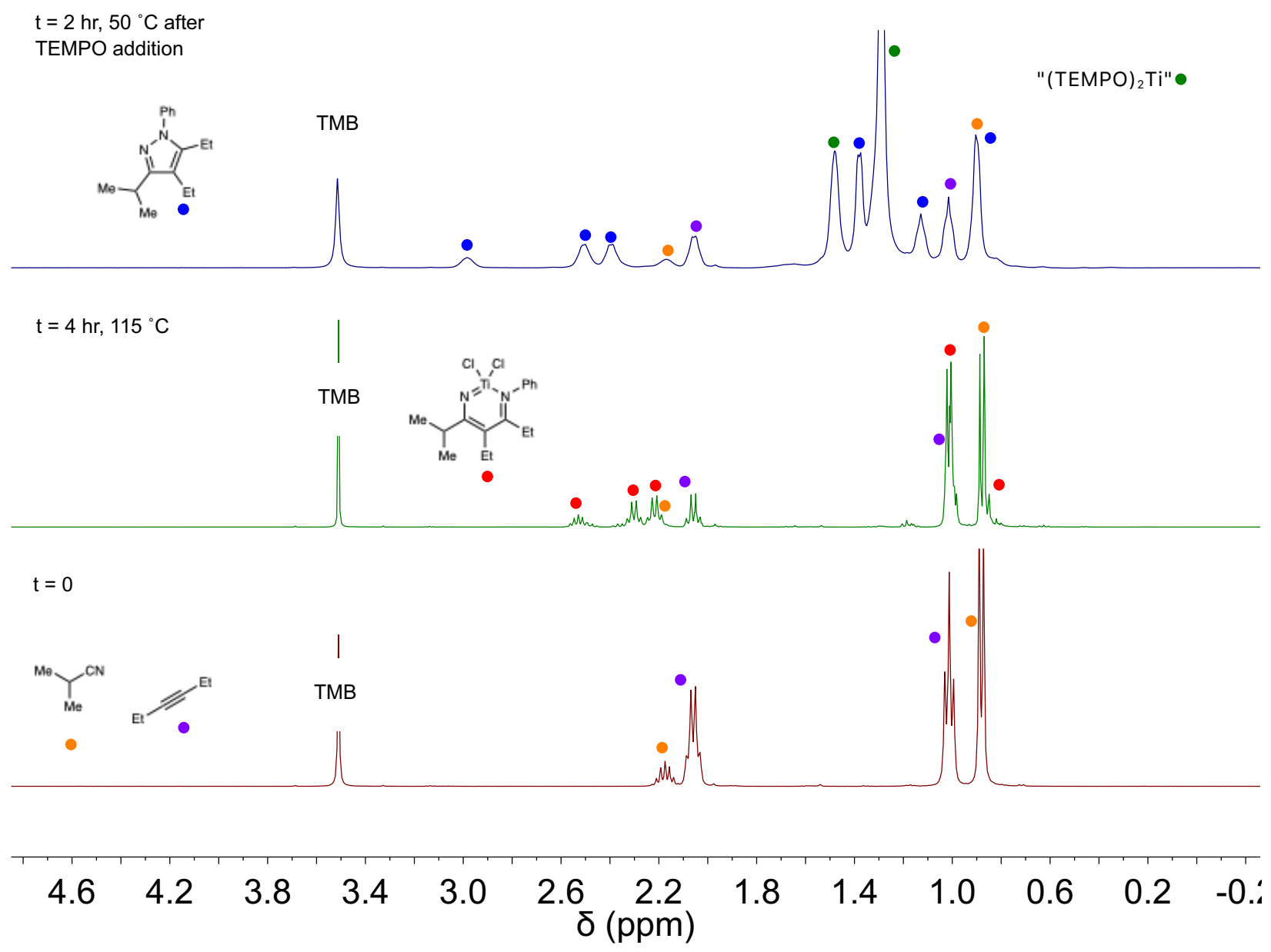

Figure S69. Stacked ${ }^{1} \mathrm{H}$ NMR spectra characterizing the multicomponent coupling of 3-hexyne, isobutyronitrile and $\left[\mathrm{py}_{2} \mathrm{TiCl}_{2}(\mathrm{NPh})\right]_{2}$ in $\mathrm{PhBr}$. Bottom (red trace): $\mathrm{t}=0$. Middle (green trace): $\mathrm{t}=4 \mathrm{~h}$ at $115^{\circ} \mathrm{C}$ generating metallacycle analogous to 7 , prior to TEMPO addition. Top (blue trace): $\mathrm{t}=2 \mathrm{~h}$ after TEMPO addition to give pyrazole $1 \mathbf{e}$.

Table 2, Entry 7
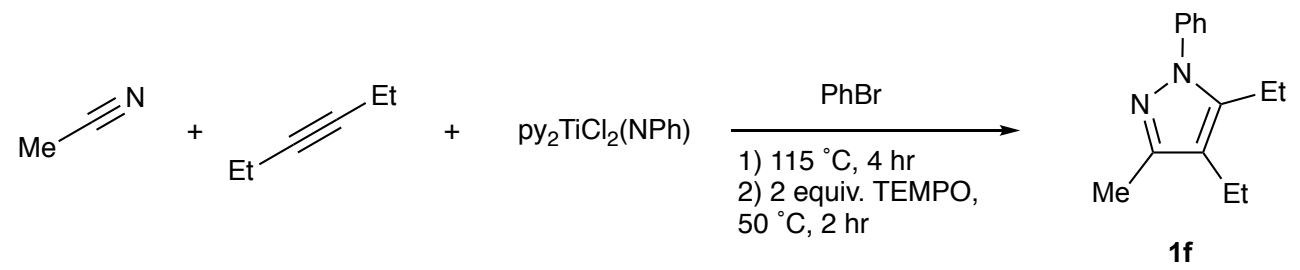


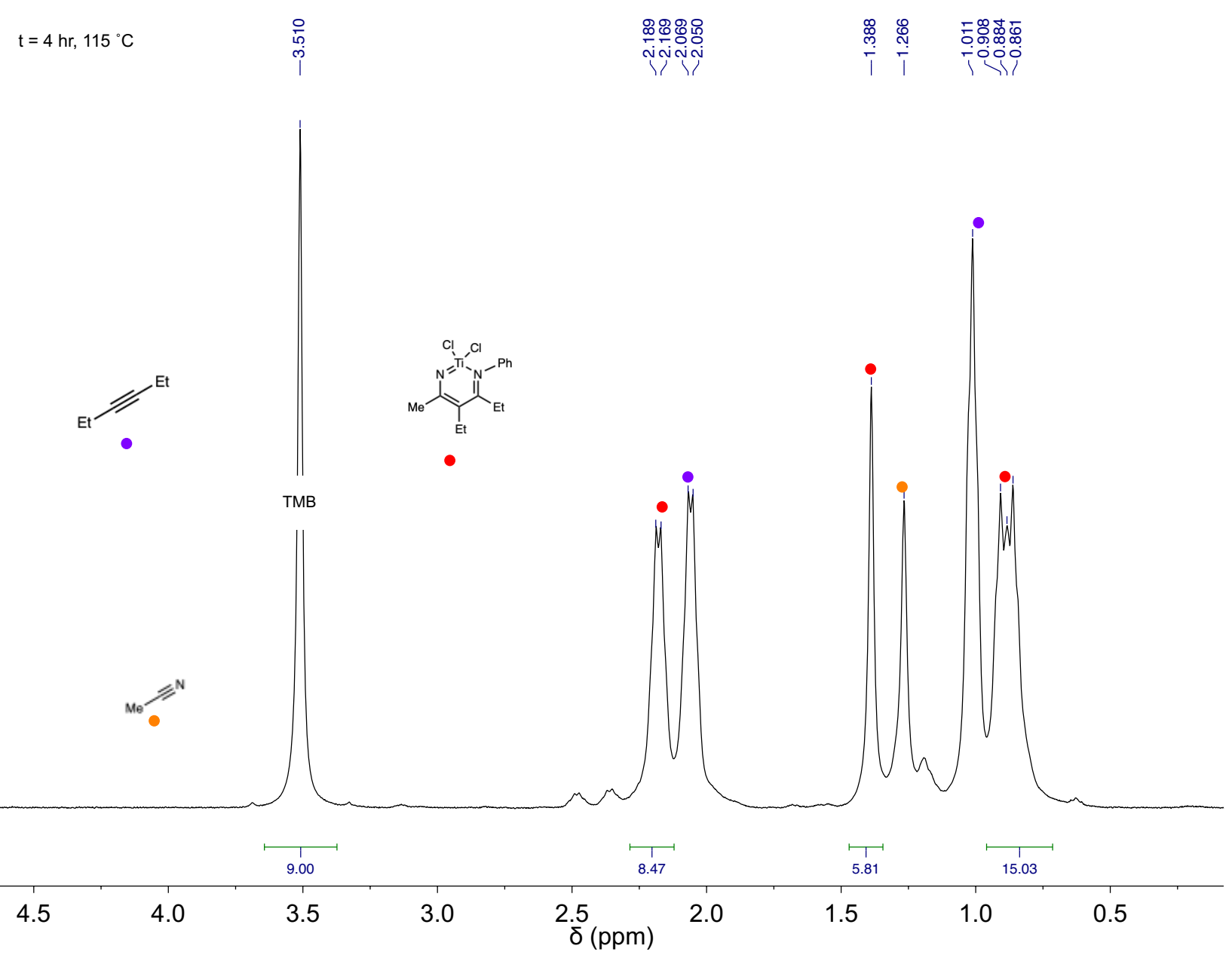

Figure S70. $t=4 \mathrm{~h}^{1} \mathrm{H}$ NMR spectrum of multicomponent coupling of 3-hexyne, acetonitrile and $\left[\mathrm{py}_{2} \mathrm{TiCl}_{2}(\mathrm{NPh})\right]_{2}$ in $\mathrm{PhBr}$. 


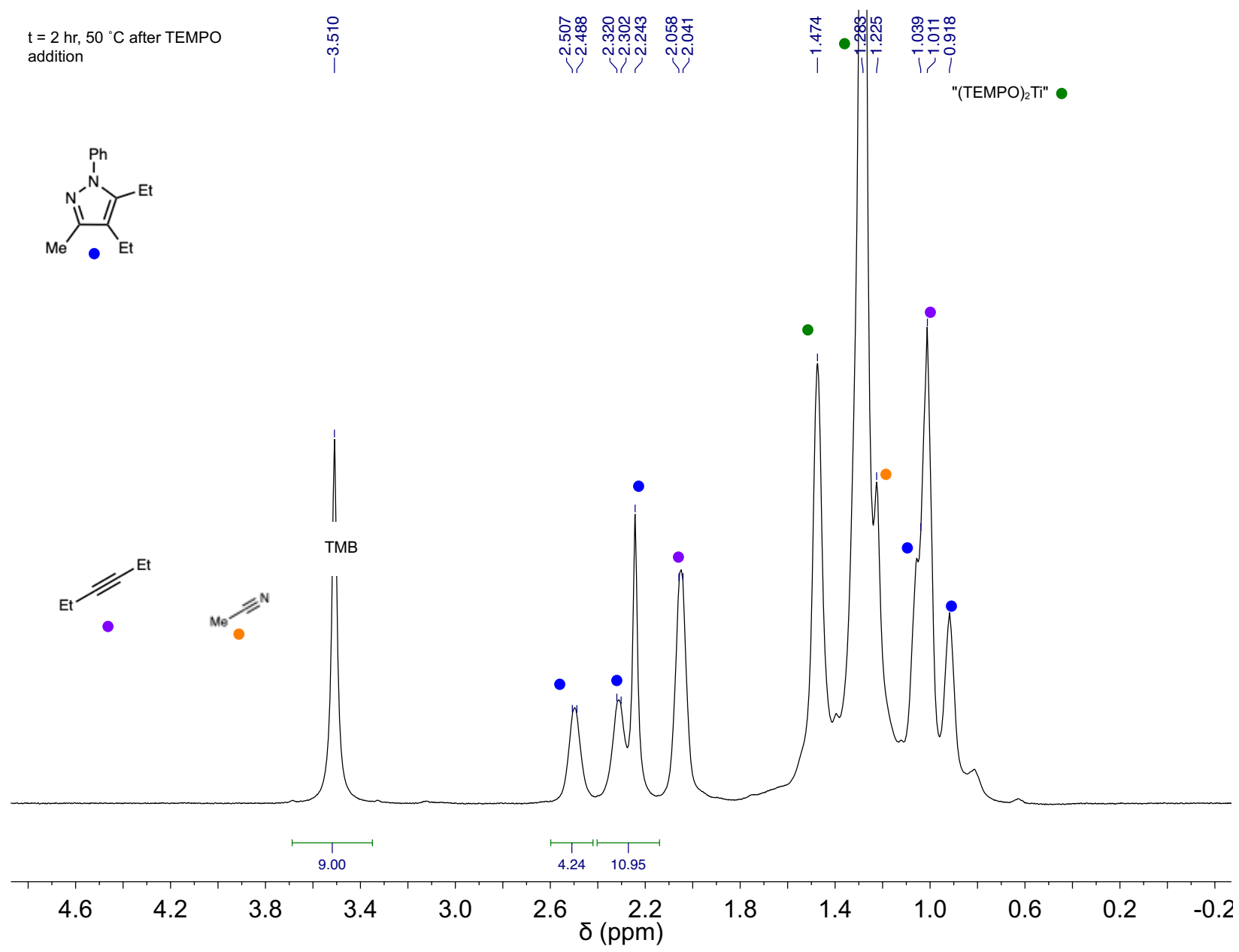

Figure S71. $\mathrm{t}=2 \mathrm{~h}{ }^{1} \mathrm{H}$ NMR spectrum of multicomponent coupling of 3-hexyne, acetonitrile and $\left[\mathrm{py}_{2} \mathrm{TiCl}_{2}(\mathrm{NPh})\right]_{2}$ in $\mathrm{PhBr}$ after TEMPO addition. 

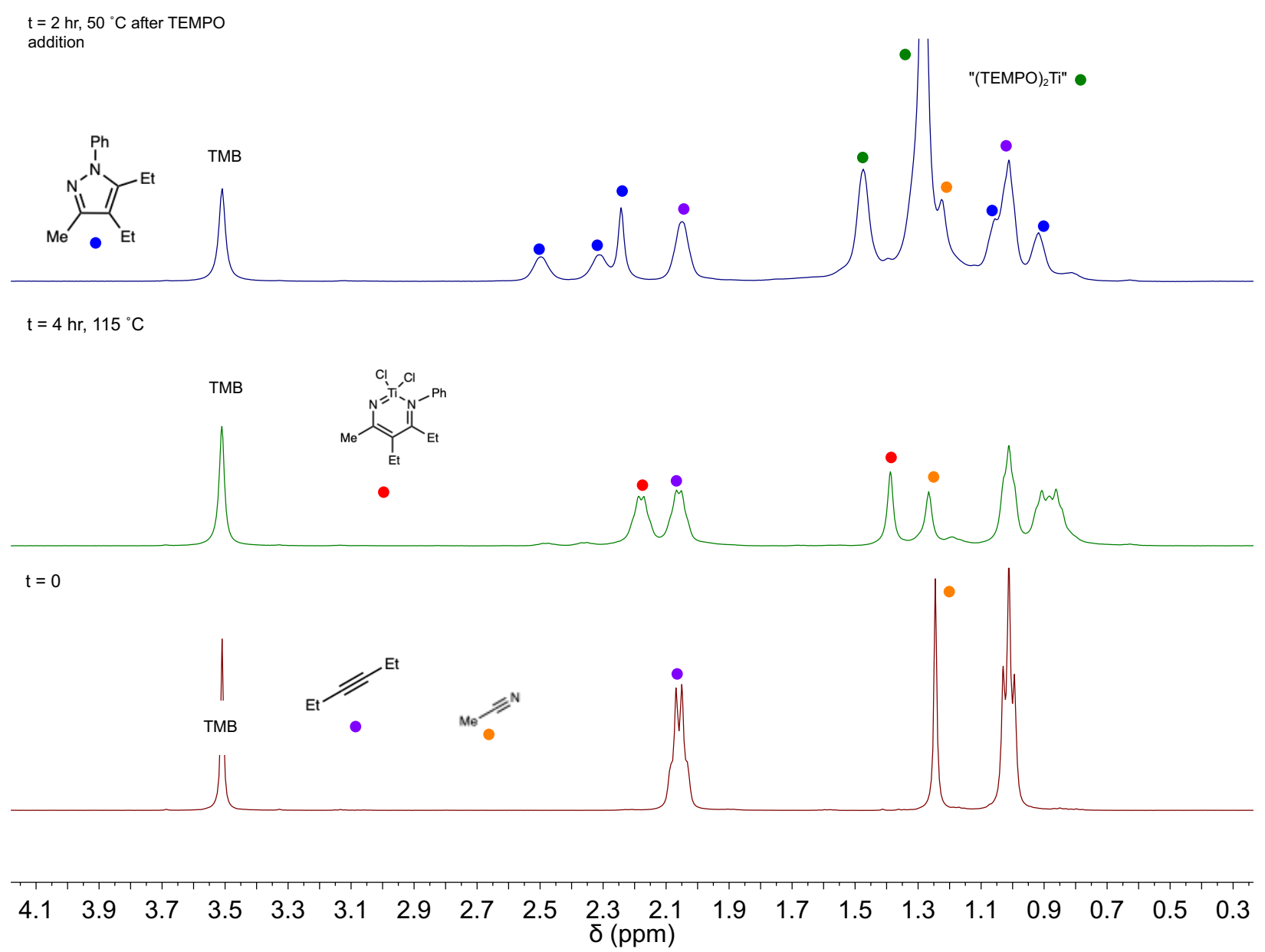

Figure S72. Stacked ${ }^{1} \mathrm{H}$ NMR spectra characterizing the multicomponent coupling of 3-hexyne, acetonitrile and $\left[\mathrm{py}_{2} \mathrm{TiCl}_{2}(\mathrm{NPh})\right]_{2}$ in $\mathrm{PhBr}$. Bottom (red trace): $\mathrm{t}=0$. Middle (green trace): $\mathrm{t}=4 \mathrm{~h}$ at 115 ${ }^{\circ} \mathrm{C}$ generating metallacycle analogous to 7, prior to TEMPO addition. Top (blue trace): $\mathrm{t}=2 \mathrm{~h}$ after TEMPO addition to give pyrazole $1 \mathrm{f}$.

Table 2, Entry 8

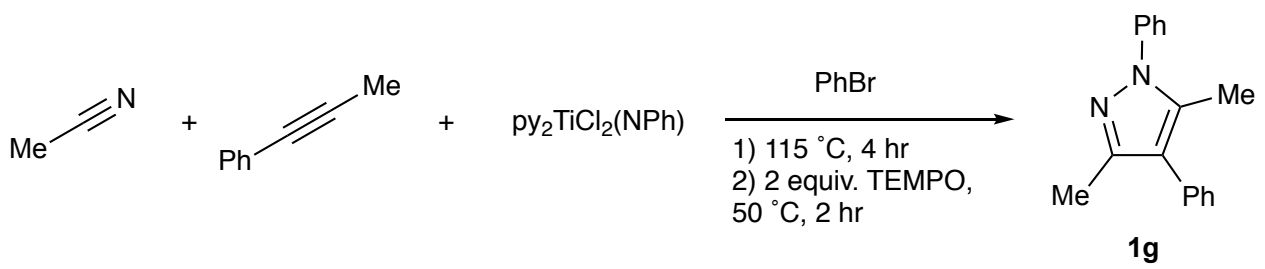




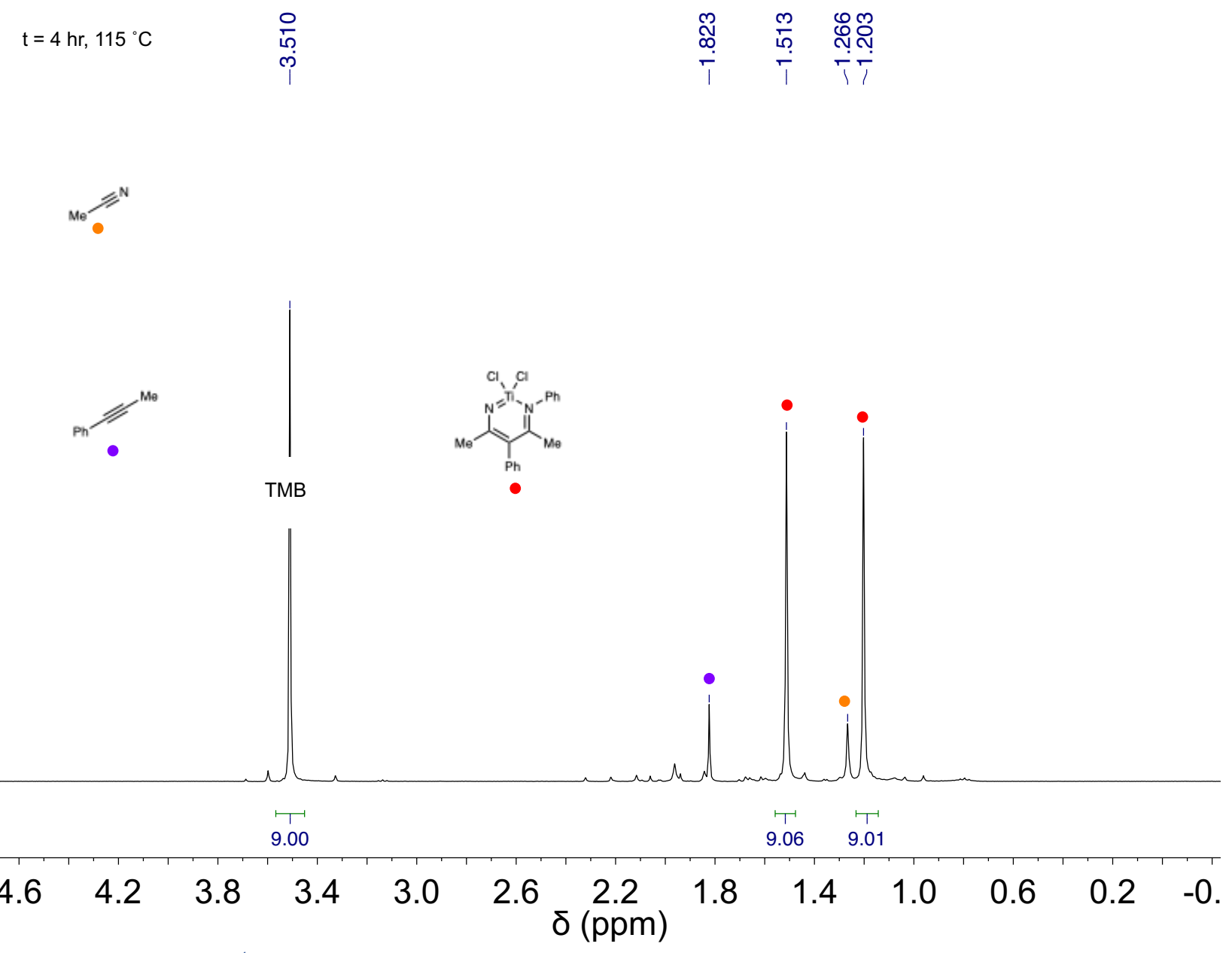

Figure S73. $\mathrm{t}=4 \mathrm{~h}{ }^{1} \mathrm{H}$ NMR spectrum of multicomponent coupling of 1-phenyl-1-propyne, acetonitrile and $\left[\mathrm{py}_{2} \mathrm{TiCl}_{2}(\mathrm{NPh})\right]_{2}$ in $\mathrm{PhBr}$. 


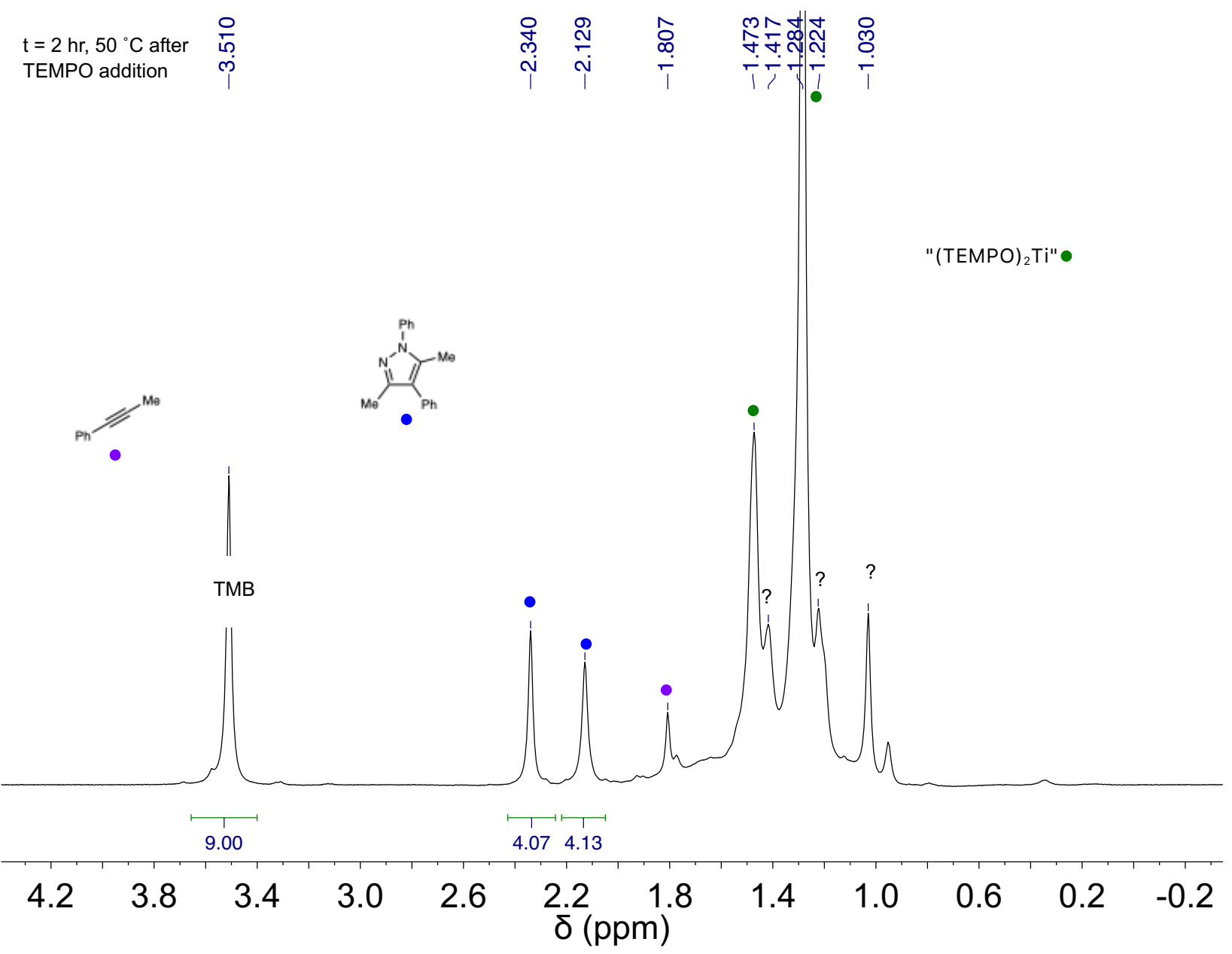

Figure S74. $\mathrm{t}=2 \mathrm{~h}{ }^{1} \mathrm{H}$ NMR spectrum of multicomponent coupling of 1-phenyl-1-propyne, acetonitrile, and $\left[\mathrm{py}_{2} \mathrm{TiCl}_{2}(\mathrm{NPh})\right]_{2}$ in $\mathrm{PhBr}$ after TEMPO addition. 


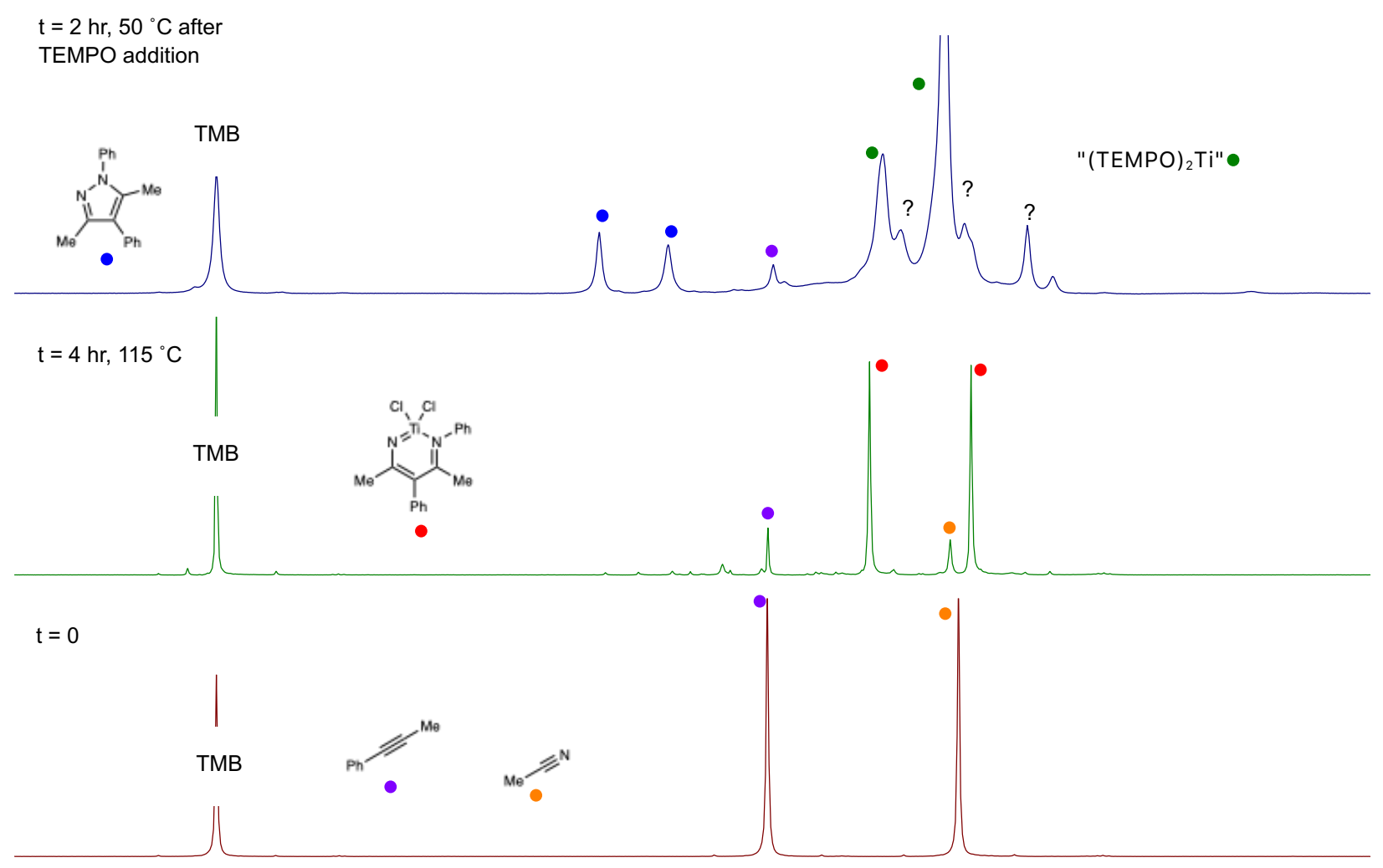

4.03 .83 .63 .43 .23 .02 .82 .62 .42 .22 .01 .81 .61 .41 .21 .00 .80 .60 .40 .20$. $\delta(\mathrm{ppm})$

Figure S75. Stacked ${ }^{1} \mathrm{H}$ NMR spectra characterizing the multicomponent coupling of 1-phenyl-1propyne, acetonitrile and $\left[\mathrm{py}_{2} \mathrm{TiCl}_{2}(\mathrm{NPh})\right]_{2}$ in $\mathrm{PhBr}$. Bottom (red trace): $\mathrm{t}=0$. Middle (green trace): $\mathrm{t}=$ $4 \mathrm{~h}$ at $115^{\circ} \mathrm{C}$ generating metallacycle 7, prior to TEMPO addition. Top (blue trace): $\mathrm{t}=2 \mathrm{~h}$ after TEMPO addition to give pyrazole $\mathbf{1 g}$.

Table 2, Entry 9
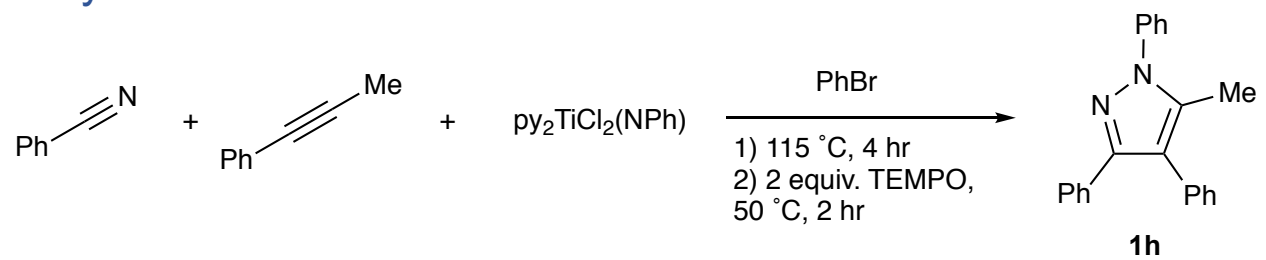
$\mathrm{t}=4 \mathrm{hr}, 115^{\circ} \mathrm{C}$

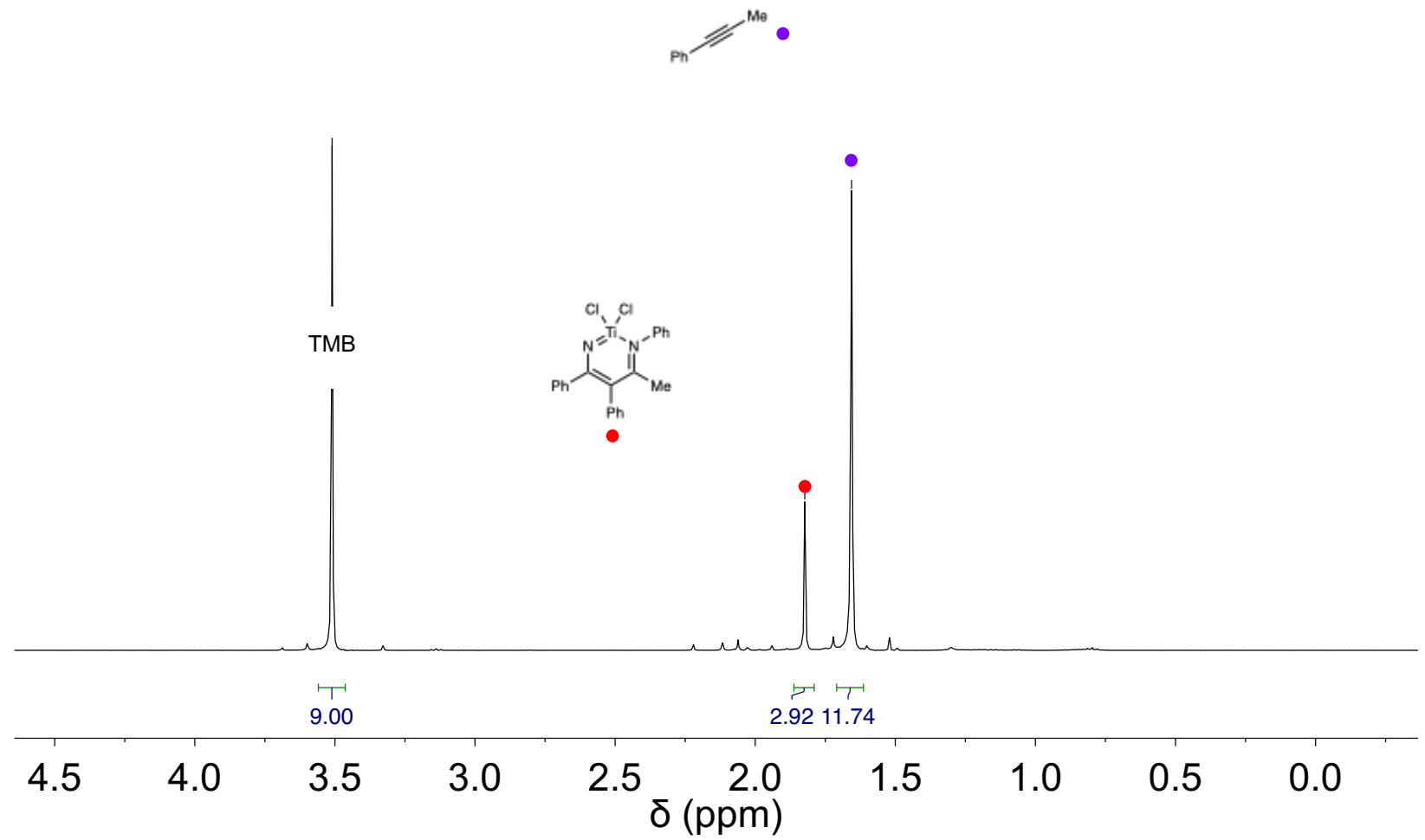

Figure S76. $\mathrm{t}=4 \mathrm{~h}{ }^{1} \mathrm{H}$ NMR spectrum of multicomponent coupling of 1-phenyl-1-propyne, benzonitrile, and $\left[\mathrm{py}_{2} \mathrm{TiCl}_{2}(\mathrm{NPh})\right]_{2}$ in $\mathrm{PhBr}$. 


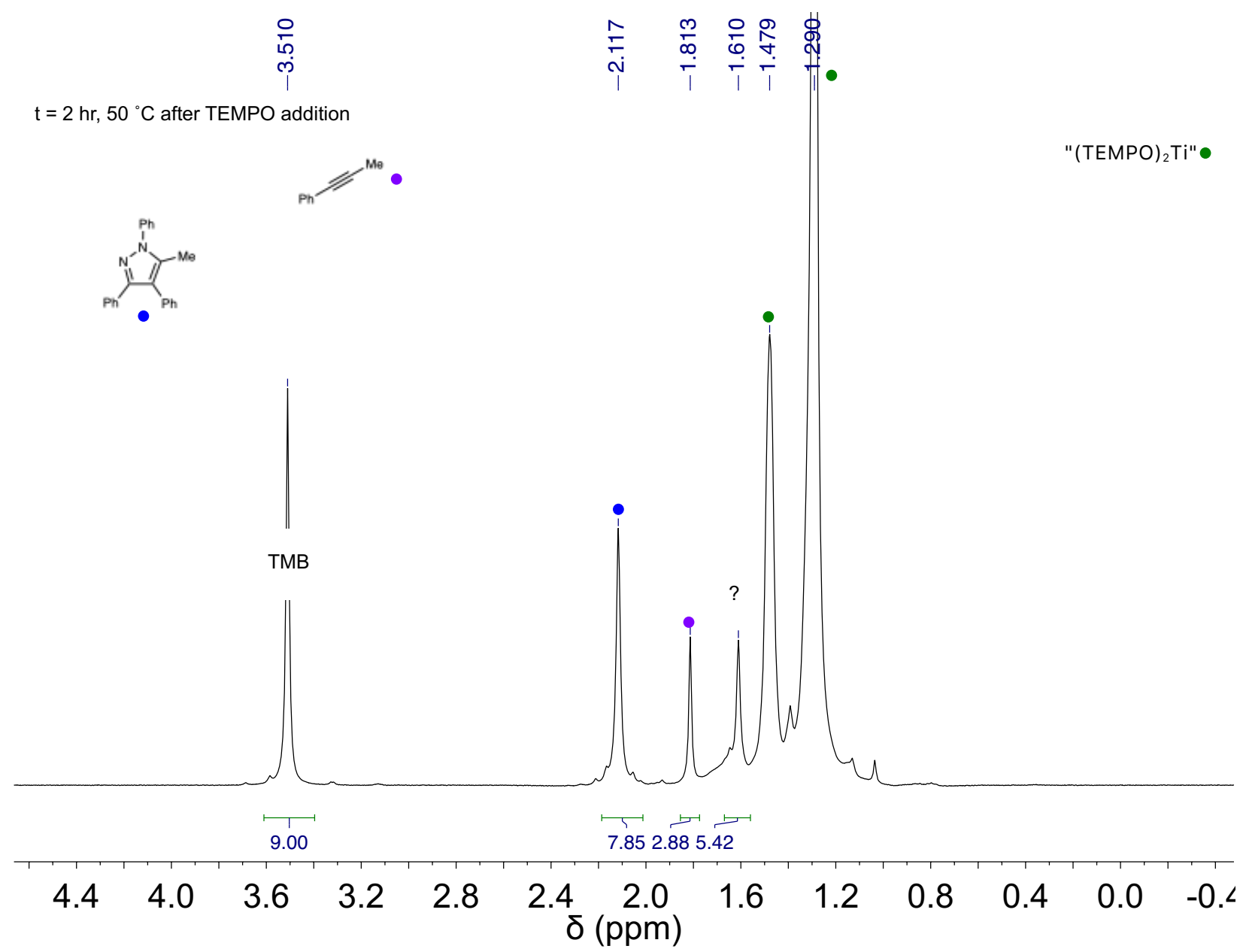

Figure S77. $\mathrm{t}=2 \mathrm{~h}{ }^{1} \mathrm{H}$ NMR spectrum of multicomponent coupling of 1-phenyl-1-propyne, benzonitrile, and $\left[\mathrm{py}_{2} \mathrm{TiCl}_{2}(\mathrm{NPh})\right]_{2}$ in $\mathrm{PhBr}$ after TEMPO addition. 

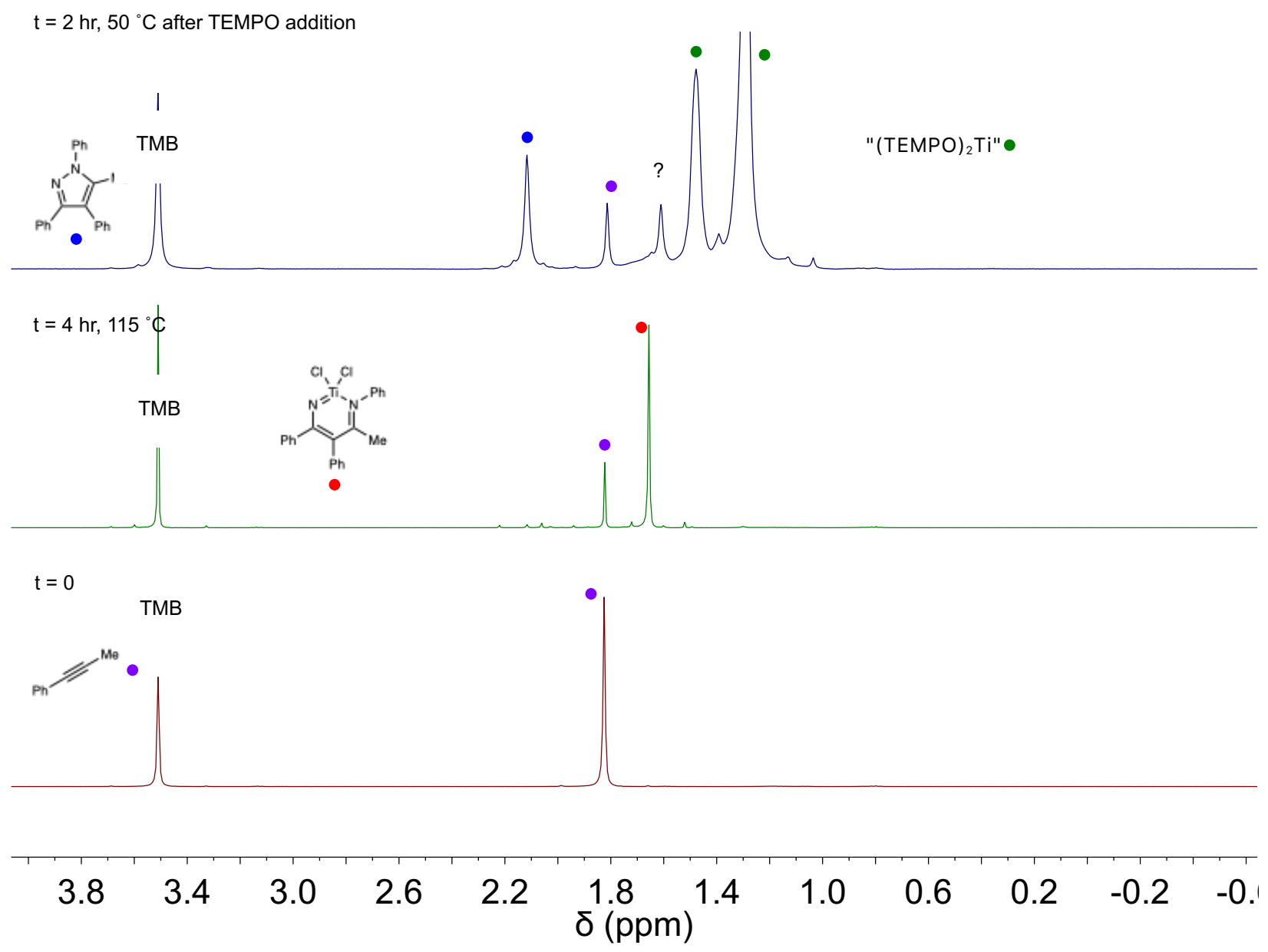

Figure S78. Stacked ${ }^{1} \mathrm{H}$ NMR spectra characterizing the multicomponent coupling of 1-phenyl-1propyne, benzonitrile and $\left[\mathrm{py}_{2} \mathrm{TiCl}_{2}(\mathrm{NPh})\right]_{2}$ in $\mathrm{PhBr}$. Bottom (red trace): $\mathrm{t}=0$. Middle (green trace): $\mathrm{t}=$ $4 \mathrm{~h}$ at $115^{\circ} \mathrm{C}$ generating metallacycle analogous to 7 , prior to TEMPO addition. Top (blue trace): $\mathrm{t}=2$ $\mathrm{h}$ after TEMPO addition to give pyrazole $1 \mathrm{~h}$.

Table 2, Entry 10

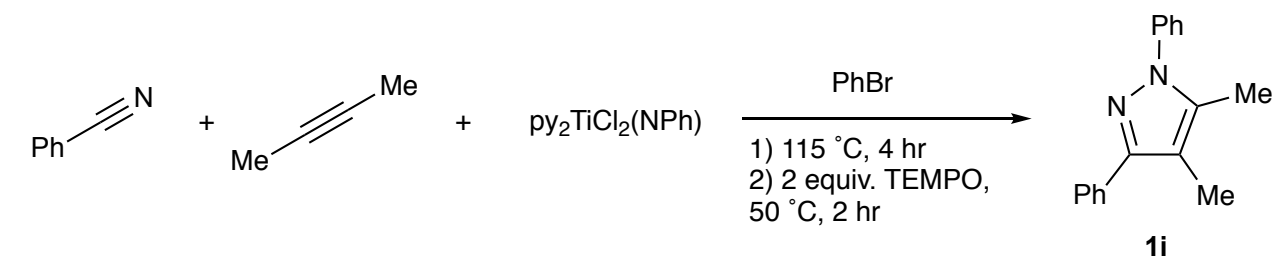



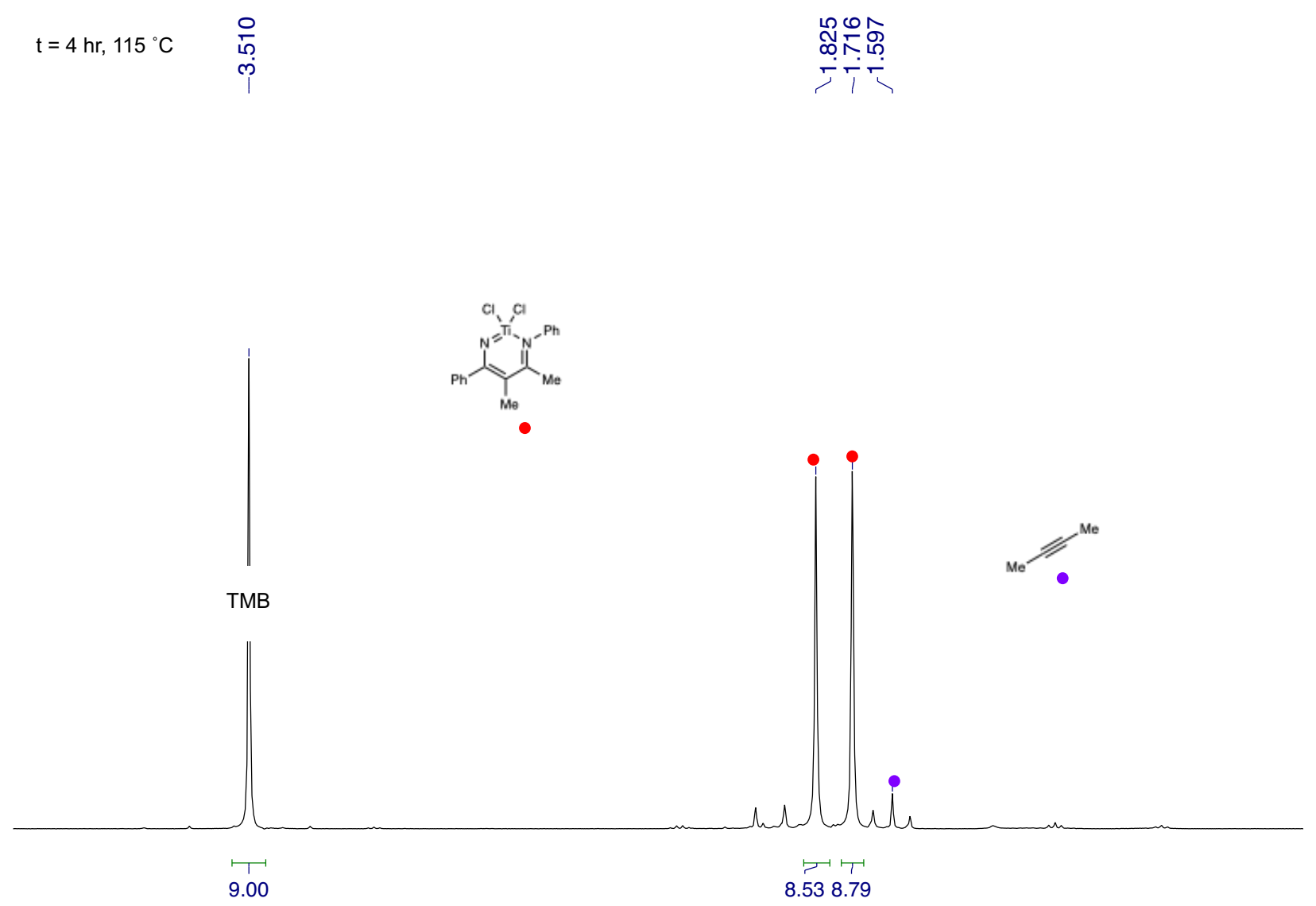

$\begin{array}{llllllllllllllllllll}.2 & 4.0 & 3.8 & 3.6 & 3.4 & 3.2 & 3.0 & 2.8 & 2.6 & 2.4 & 2.2 & 2.0 & 1.8 & 1.6 & 1.4 & 1.2 & 1.0 & 0.8 & 0.6 & 0 .\end{array}$ $\delta(\mathrm{ppm})$

Figure S79. $\mathrm{t}=4 \mathrm{~h}{ }^{1} \mathrm{H}$ NMR spectrum of multicomponent coupling of 2-butyne, benzonitrile and $\left[\mathrm{py}_{2} \mathrm{TiCl}_{2}(\mathrm{NPh})\right]_{2}$ in $\mathrm{PhBr}$. 


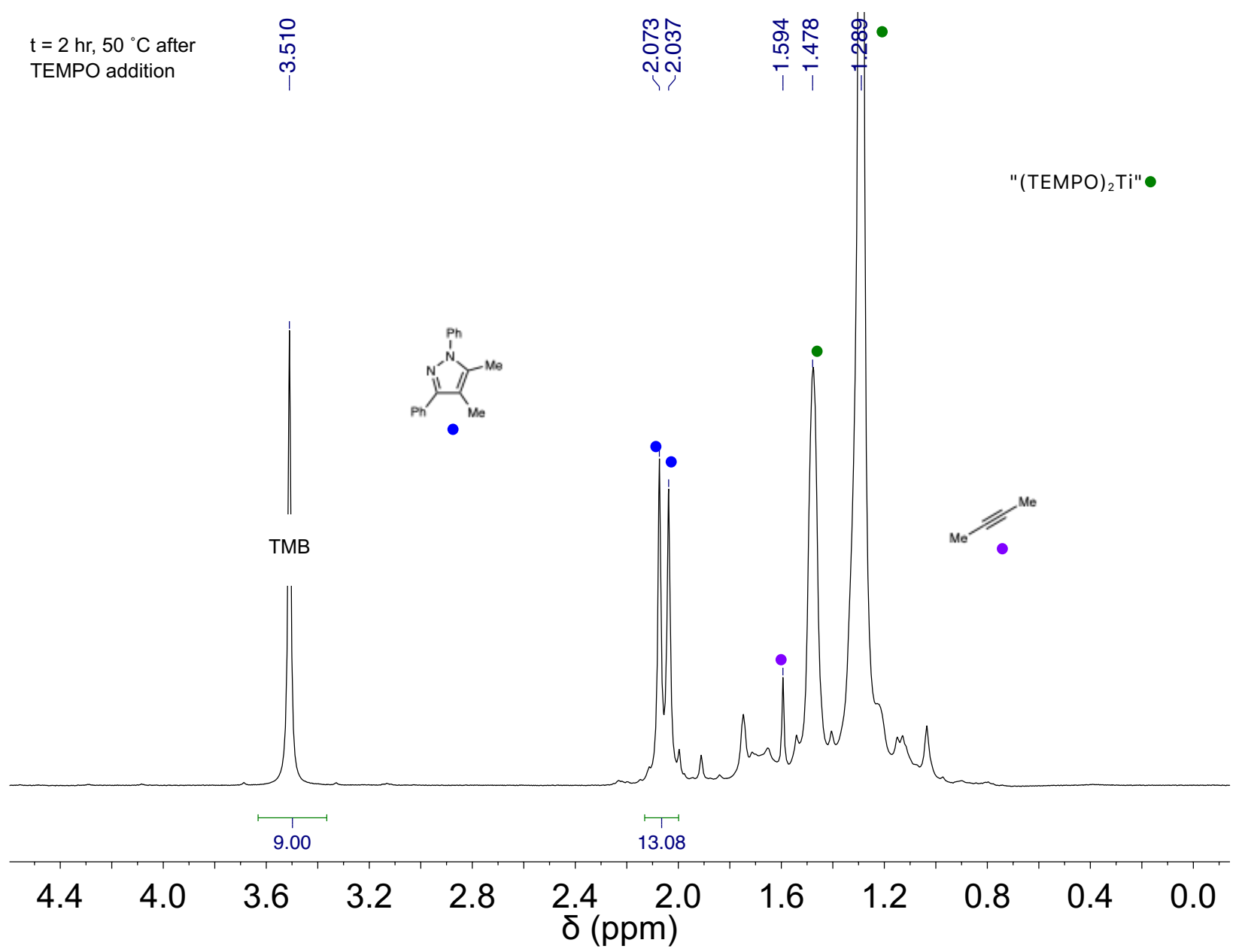

Figure S80. $\mathrm{t}=2 \mathrm{~h}{ }^{1} \mathrm{H}$ NMR spectrum of multicomponent coupling of 2-butyne, benzonitrile and $\left[\mathrm{py}_{2} \mathrm{TiCl}_{2}(\mathrm{NPh})\right]_{2}$ in $\mathrm{PhBr}$ after TEMPO addition. 


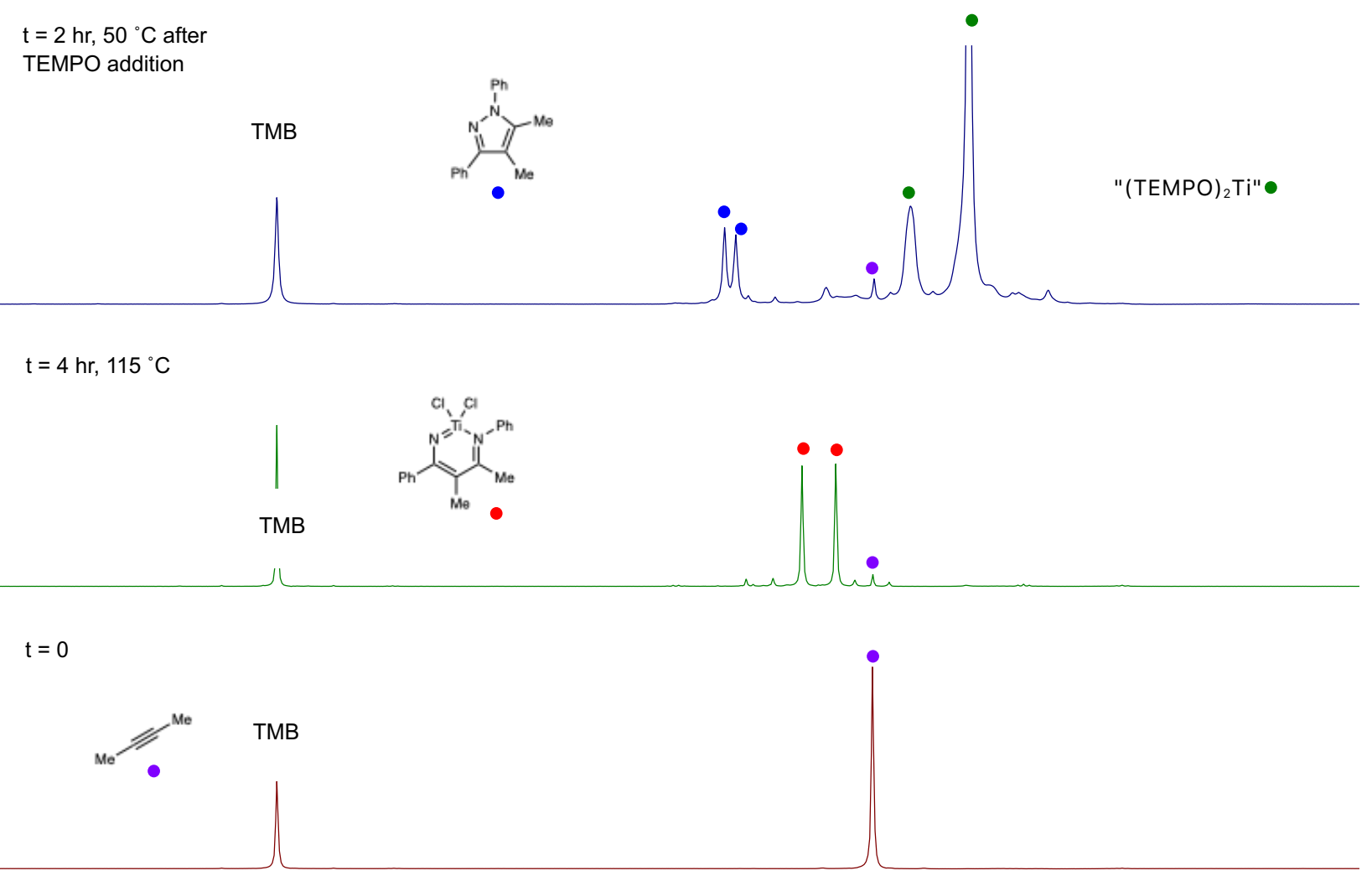

\subsection{4 .03 .83 .63 .43 .23 .02 .82 .62 .42 .22 .01 .81 .61 .41 .21 .00 .80 .60 .40 .2 $\delta(\mathrm{ppm})$}

Figure S81. Stacked ${ }^{1} \mathrm{H}$ NMR spectra characterizing the multicomponent coupling of 2-butyne, benzonitrile and $\left[\mathrm{py}_{2} \mathrm{TiCl}_{2}(\mathrm{NPh})\right]_{2}$ in $\mathrm{PhBr}$. Bottom (red trace): $\mathrm{t}=0$. Middle (green trace): $\mathrm{t}=4 \mathrm{~h}$ at 115 ${ }^{\circ} \mathrm{C}$ generating metallacycle analogous to 7, prior to TEMPO addition. Top (blue trace): $\mathrm{t}=2 \mathrm{~h}$ after TEMPO addition to give pyrazole $\mathbf{1 i}$.

Table 2, Entry 11<smiles>N#Cc1ccccc1</smiles><smiles>CC(C)(C)c1ccc(-c2c(-c3ccccc3)c(-c3ccccc3)nn2-c2ccccc2)cc1</smiles> 


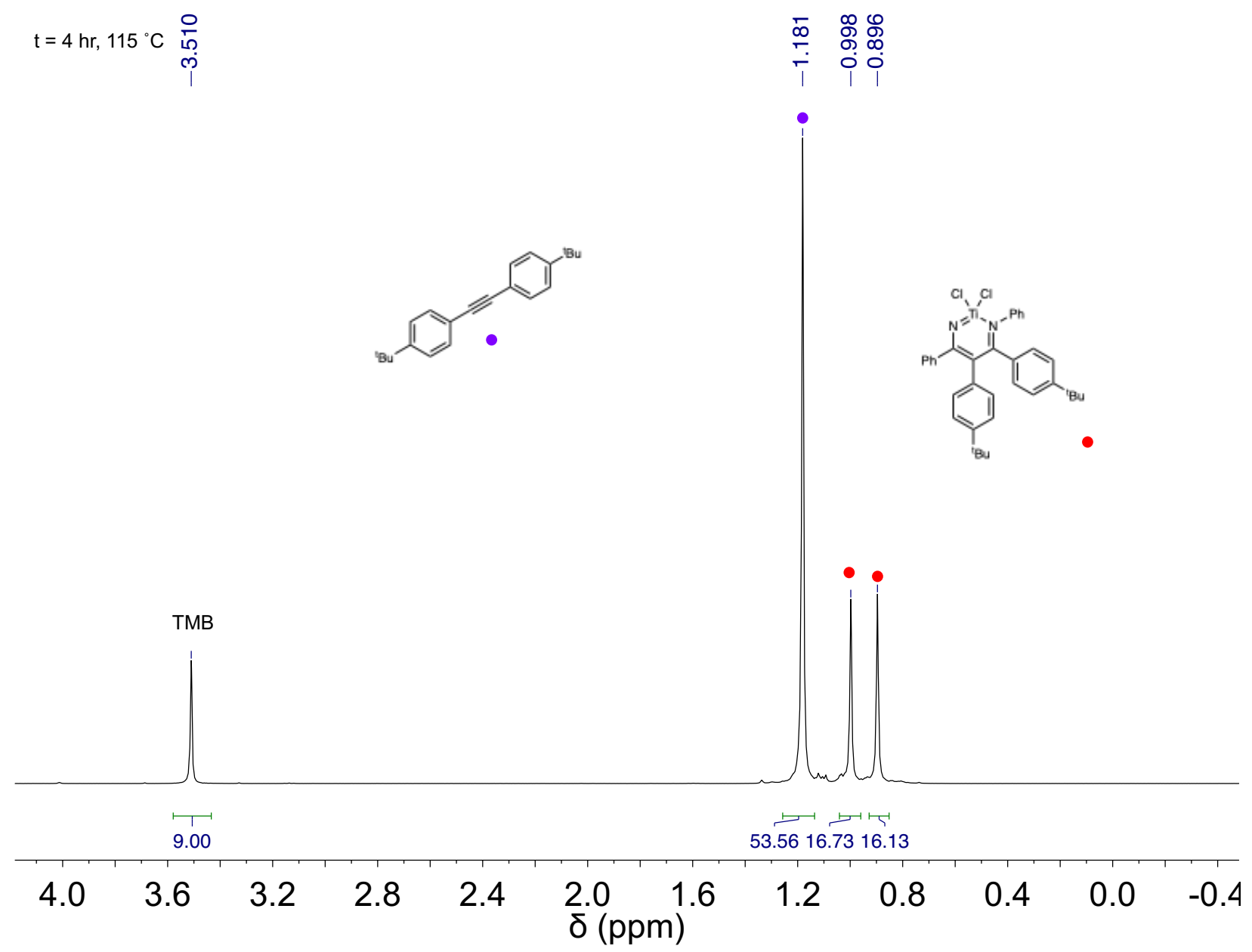

Figure S82. $\mathrm{t}=4 \mathrm{~h}{ }^{1} \mathrm{H}$ NMR spectrum of multicomponent coupling of bis(4-t-butylphenyl)acetylene, benzonitrile and $\left[\mathrm{py}_{2} \mathrm{TiCl}_{2}(\mathrm{NPh})\right]_{2}$ in $\mathrm{PhBr}$. 


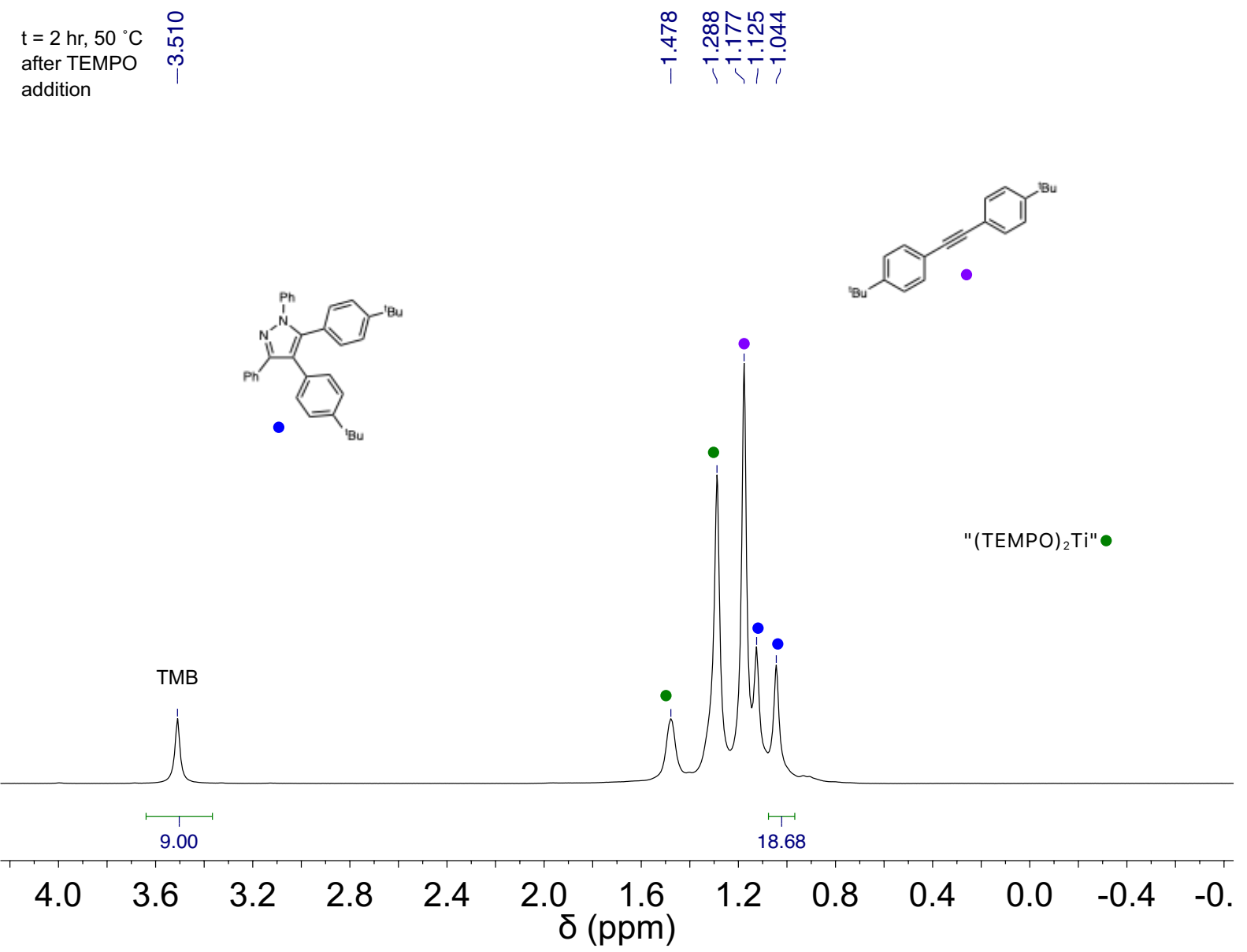

Figure S83. $\mathrm{t}=4 \mathrm{~h}{ }^{1} \mathrm{H}$ NMR spectrum of multicomponent coupling of bis(4-t-butylphenyl)acetylene, benzonitrile and $\left[\mathrm{py}_{2} \mathrm{TiCl}_{2}(\mathrm{NPh})\right]_{2}$ in $\mathrm{PhBr}$ after TEMPO addition. 


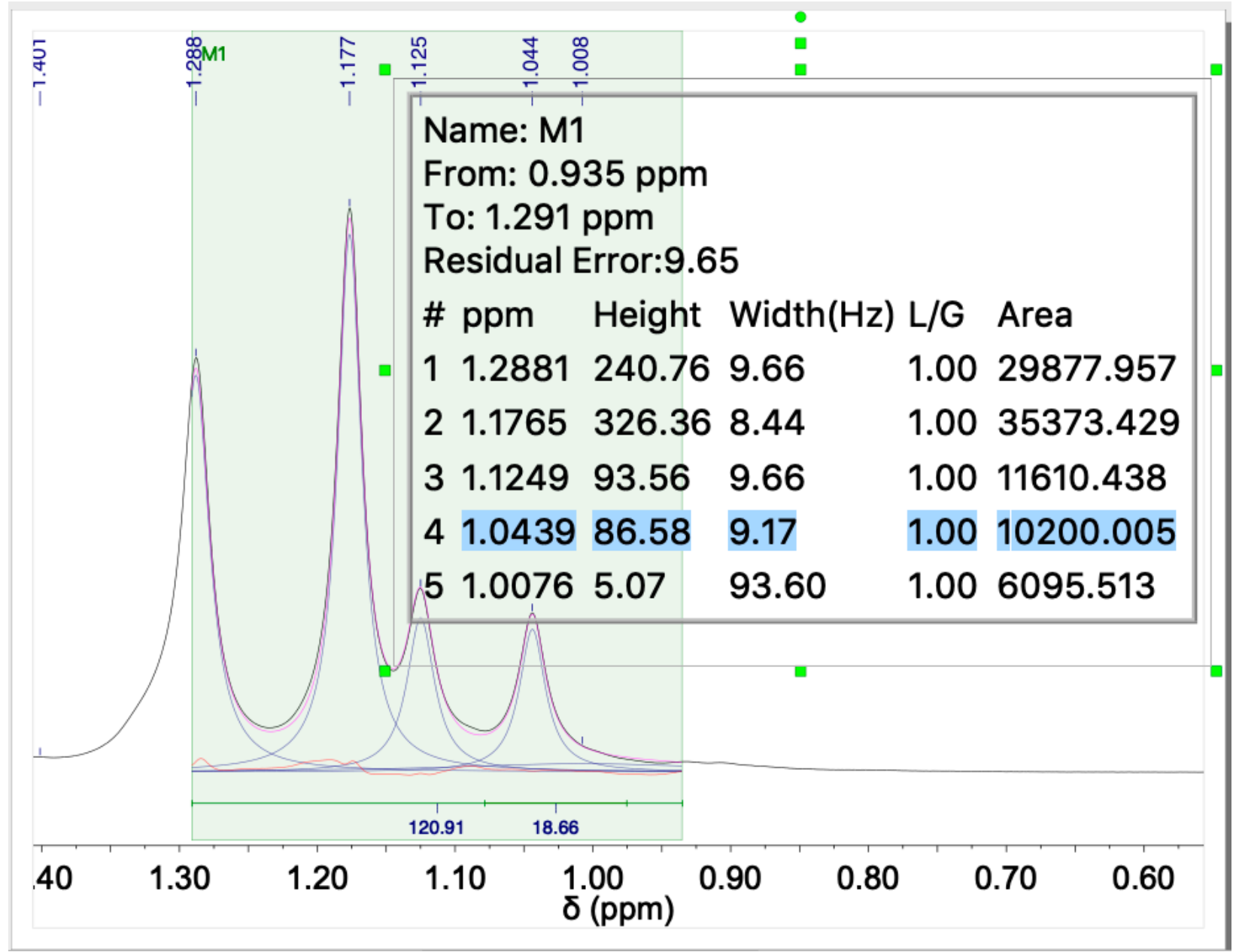

Figure S84. $\mathrm{t}=2 \mathrm{~h}{ }^{1} \mathrm{H}$ NMR spectrum of multicomponent coupling of bis(4-t-butylphenyl)acetylene, benzonitrile, and $\left[\mathrm{py}_{2} \mathrm{TiCl}_{2}(\mathrm{NPh})\right]_{2}$ in $\mathrm{PhBr}$ after TEMPO addition showing zoomed-in view of t-butyl peak deconvolution, with inset showing deconvolution results table.

Table S1. Deconvolution results for partially overlapped t-butyl peaks, with calculations for adjusted integration area for product $1 \mathrm{j}$ peak shown.

Name:

M1

From: $0.935 \mathrm{ppm}$

Integration of Total Area=

144.62

To: $1.361 \mathrm{ppm}$

Residual Error:51.1

\begin{tabular}{rrrrrrl} 
\# & \multicolumn{1}{c}{ ppm } & Height & Width(Hz) & L/G & \multicolumn{3}{l}{ Area } & \\
1 & 1.2881 & 240.76 & 9.66 & 1 & 29877.96 & \\
2 & 1.1765 & 326.36 & 8.44 & 1 & 35373.43 & \\
3 & 1.1249 & 93.56 & 9.66 & 1 & 11610.44 \% of Area
\end{tabular}




\begin{tabular}{|c|c|c|c|c|c|}
\hline 4 & 1.0439 & 86.58 & 9.17 & 1 & 10200.01 \\
\hline 5 & 1.0076 & 5.07 & 93.6 & 1 & 6095.513 \\
\hline & & & & & 93157.342 \\
\hline
\end{tabular}

\section{Adjusted Integration}

$120.91 \times \quad 10.9 \%=\quad \mathbf{1 5 . 8 3 4 7 6 6 1}$

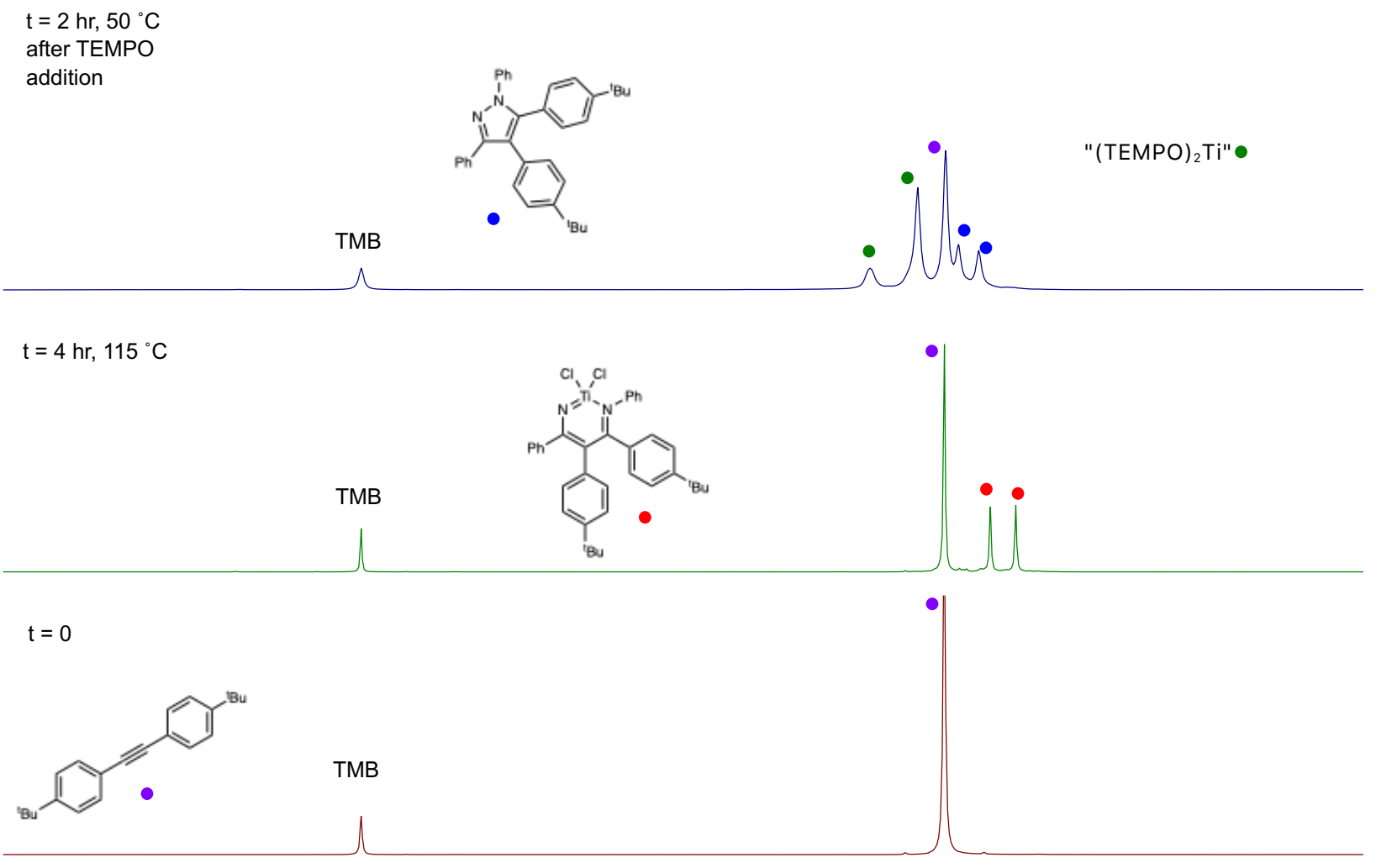

\section{$\begin{array}{llllllllllllll}4.8 & 4.4 & 4.0 & 3.6 & 3.2 & 2.8 & \begin{array}{l}2.4 \\ \delta(\mathrm{ppm})\end{array} & 2.0 & 1.6 & 1.2 & 0.8 & 0.4 & 0.0 & -0.4\end{array}$}

Figure S85. Stacked ${ }^{1} \mathrm{H}$ NMR spectra characterizing the multicomponent coupling of bis(4-tbutylphenyl)acetylene, benzonitrile and $\left[\mathrm{py}_{2} \mathrm{TiCl}_{2}(\mathrm{NPh})\right]_{2}$ in $\mathrm{PhBr}$. Bottom (red trace): $\mathrm{t}=0$. Middle (green trace): $\mathrm{t}=4 \mathrm{~h}$ at $115^{\circ} \mathrm{C}$ generating metallacycle analogous to 7 , prior to TEMPO addition. Top (blue trace): $\mathrm{t}=2 \mathrm{~h}$ after TEMPO addition to give pyrazole $1 \mathrm{j}$. 


\section{Scale-up of Table 2, Entry 3 for isolation}<smiles>CCC#CC#C[TeH]</smiles>

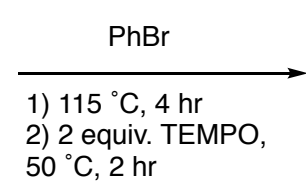<smiles>CCc1c(-c2ccccc2)nn(-c2ccccc2)c1CC</smiles>

$1 \mathrm{~b}$

Procedure: In a scintillation vial, $\left[\mathrm{py}_{2} \mathrm{TiCl}_{2}(\mathrm{NPh})\right]_{2}(368 \mathrm{mg}, 1.00 \mathrm{mmol}, 1$ equiv), benzonitrile (116 mg, $1.00 \mathrm{mmol}, 1.00$ equiv), 3-hexyne (113 $\mu \mathrm{L}, 1.00 \mathrm{mmol}, 1.00$ equiv), and bromobenzene (approx. $10 \mathrm{~mL}$ ) was added, followed by a stir bar. The vial was sealed with a Teflon cap, wrapped with electrical tape, and removed from the glovebox. The vial was heated to $115^{\circ} \mathrm{C}$ with stirring for 4 hours, after which the vial was brought back into the glovebox, where TEMPO $(310 \mathrm{mg}, 1.98 \mathrm{mmol}$, 1.98 equiv) was added. The vial was capped and taped, removed from the glovebox, and heated to $50{ }^{\circ} \mathrm{C}$ for 2 hours. The reaction was quenched by pouring onto silica. Elution with DCM and evaporation of the volatiles yields $\mathbf{1 b}$ (179 $\mathrm{mg}$ corrected yield from $4 \%$ pyrrole, $4 \%$ hexane, and $2 \%$ silicone grease impurities $-65 \%$ yield).

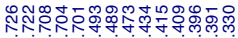

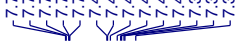
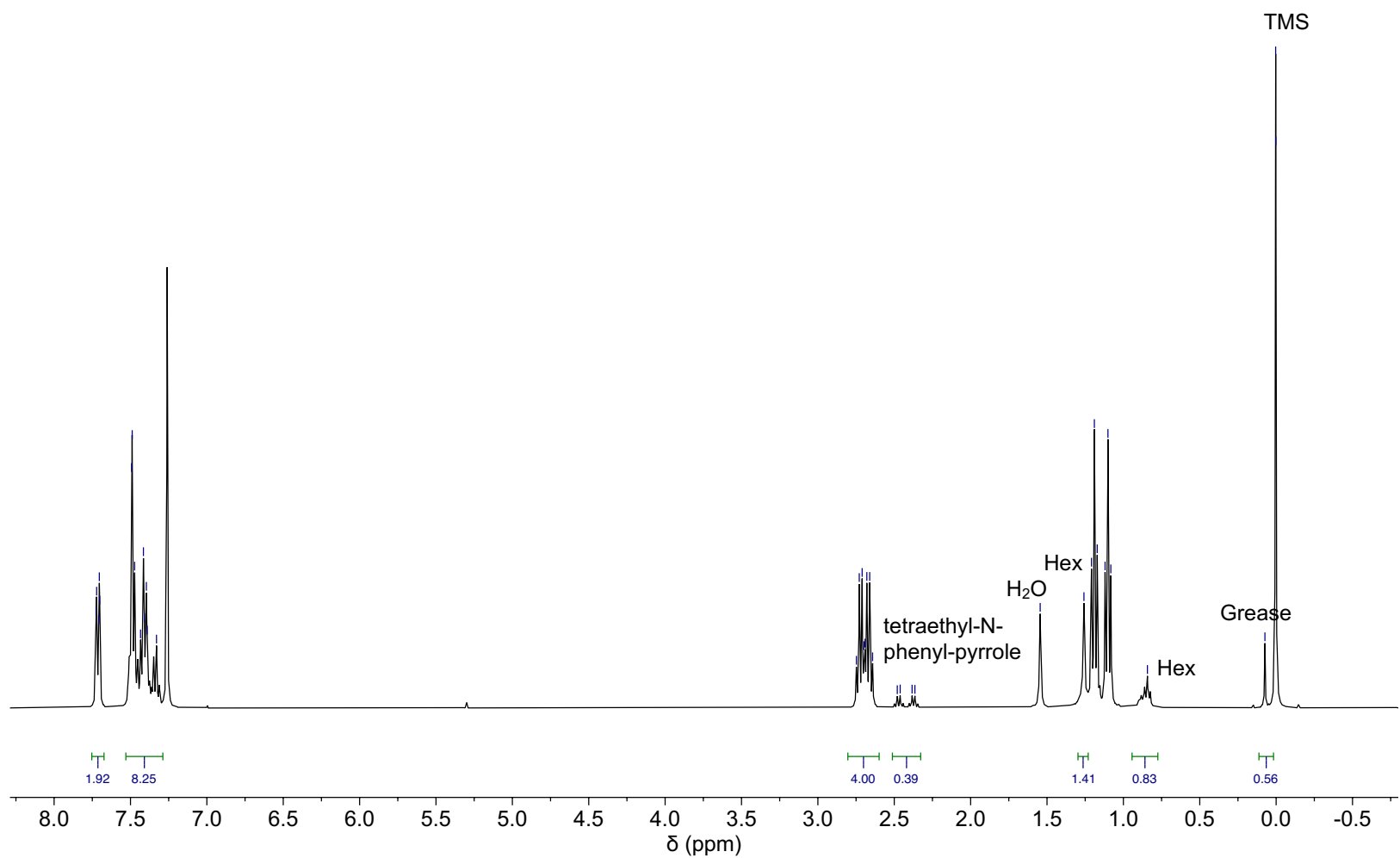

Figure S86. ${ }^{1} \mathrm{H}$ NMR spectrum of isolated material from scale up of $\mathbf{1 b}$. 
Multicomponent coupling of azobenzene, 3-hexyne and $p$ tolunitrile catalyzed by $\mathrm{py}_{2} \mathrm{TiCl}_{2}(\mathrm{NPh})$
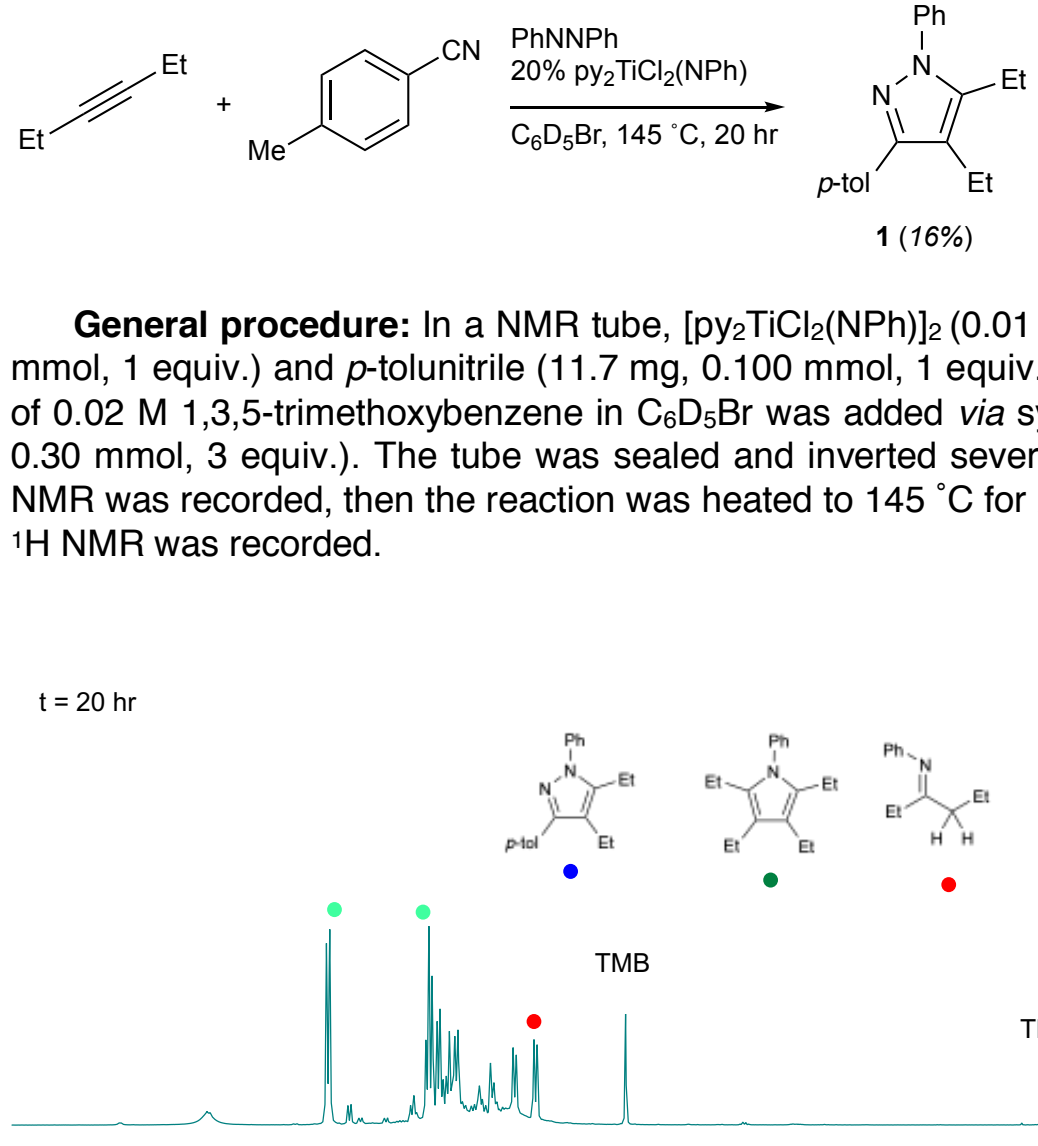
$1 \mathrm{H}$ NMR was recorded.<smiles>CCc1c([AlH2])nn(-c2ccccc2)c1CC</smiles><smiles>CCC(=Nc1ccccc1)C(C)C</smiles><smiles>CCc1c(CC)c(CC)n(-c2ccccc2)c1CC</smiles>

General procedure: In a NMR tube, $\left[\mathrm{py}_{2} \mathrm{TiCl}_{2}(\mathrm{NPh})\right]_{2}(0.01 \mathrm{mmol})$, azobenzene $(18.2 \mathrm{mg}, 0.100$ mmol, 1 equiv.) and $p$-tolunitrile $(11.7 \mathrm{mg}, 0.100 \mathrm{mmol}, 1$ equiv.) were massed out as solids. $0.5 \mathrm{~mL}$ of $0.02 \mathrm{M} \mathrm{1,3,5-trimethoxybenzene} \mathrm{in} \mathrm{C}_{6} \mathrm{D}_{5} \mathrm{Br}$ was added via syringe, followed by 3-hexyne (34 $\mu \mathrm{L}$, $0.30 \mathrm{mmol}, 3$ equiv.). The tube was sealed and inverted several times to mix. $A t=0$ timepoint ${ }^{1} \mathrm{H}$ NMR was recorded, then the reaction was heated to $145^{\circ} \mathrm{C}$ for 20 hours. Afterwards, a post reaction

$t=0$

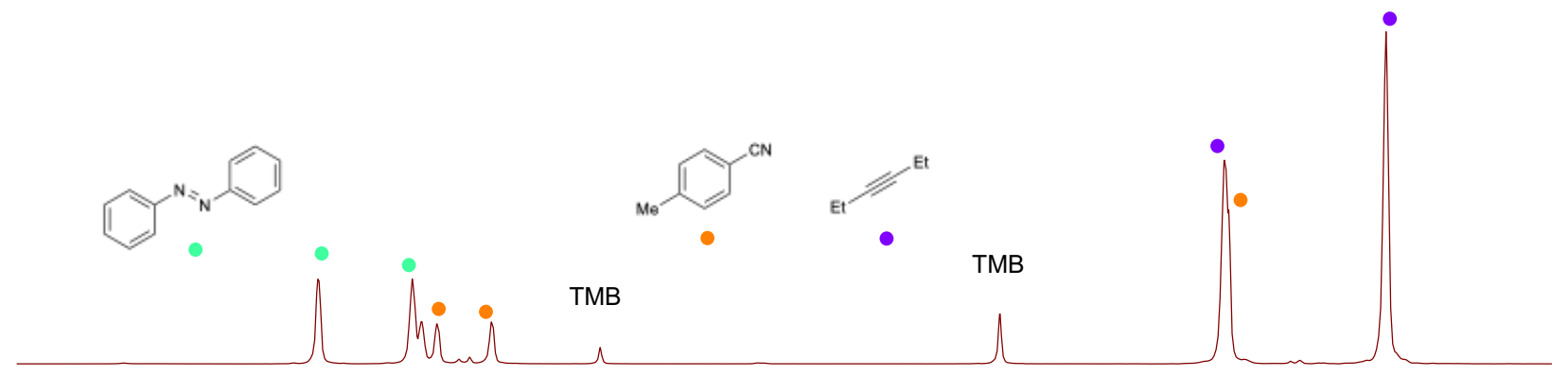

$9.5 \quad 9.0 \quad 8.5 \quad 8.07 .57 .0 \quad 6.5 \quad 6.0 \quad 5.5 \quad 5.04 .5 \quad 4.0 \quad 3.5 \quad 3.02 .52 .0 \quad 1.5 \quad 1.0 \quad 0.5 \quad 0.1$ $\delta(\mathrm{ppm})$

Figure S87. ${ }^{1} \mathrm{H}$ NMR spectra (stacked) of the $t=0$ and $t=22 \mathrm{~h}$ time point of the catalytic multicomponent coupling of azobenzene, 3-hexyne and $p$-tolunitrile catalyzed by $\mathrm{py}_{2} \mathrm{TiCl}_{2}(\mathrm{NPh})$. 


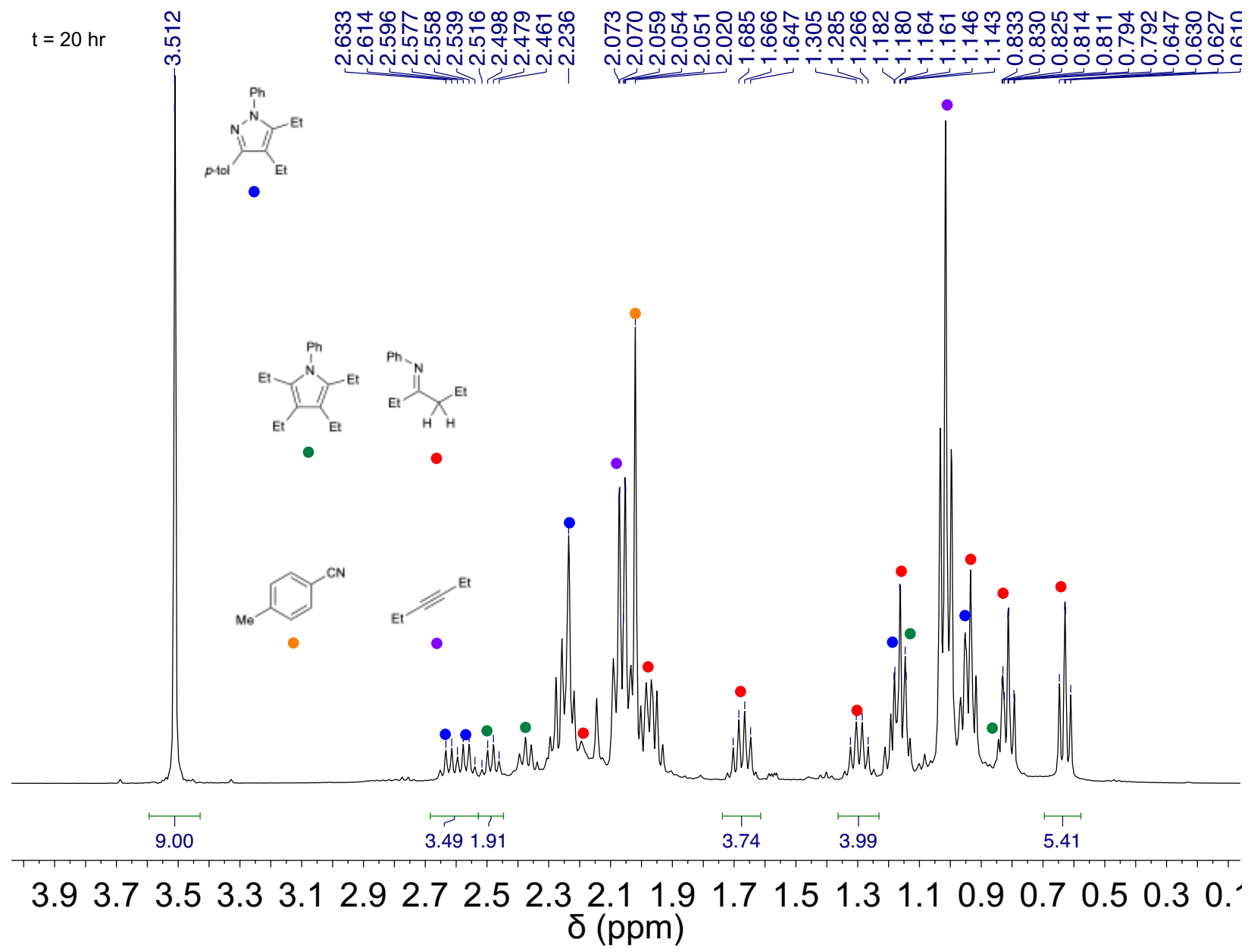

Figure S88. ${ }^{1} \mathrm{H}$ NMR spectrum (alkyl region) of the $\mathrm{t}=22 \mathrm{~h}$ time point of the catalytic multicomponent coupling of azobenzene, 3-hexyne and $p$-tolunitrile catalyzed by $\mathrm{py}_{2} \mathrm{TiCl}_{2}(\mathrm{NPh})$. 


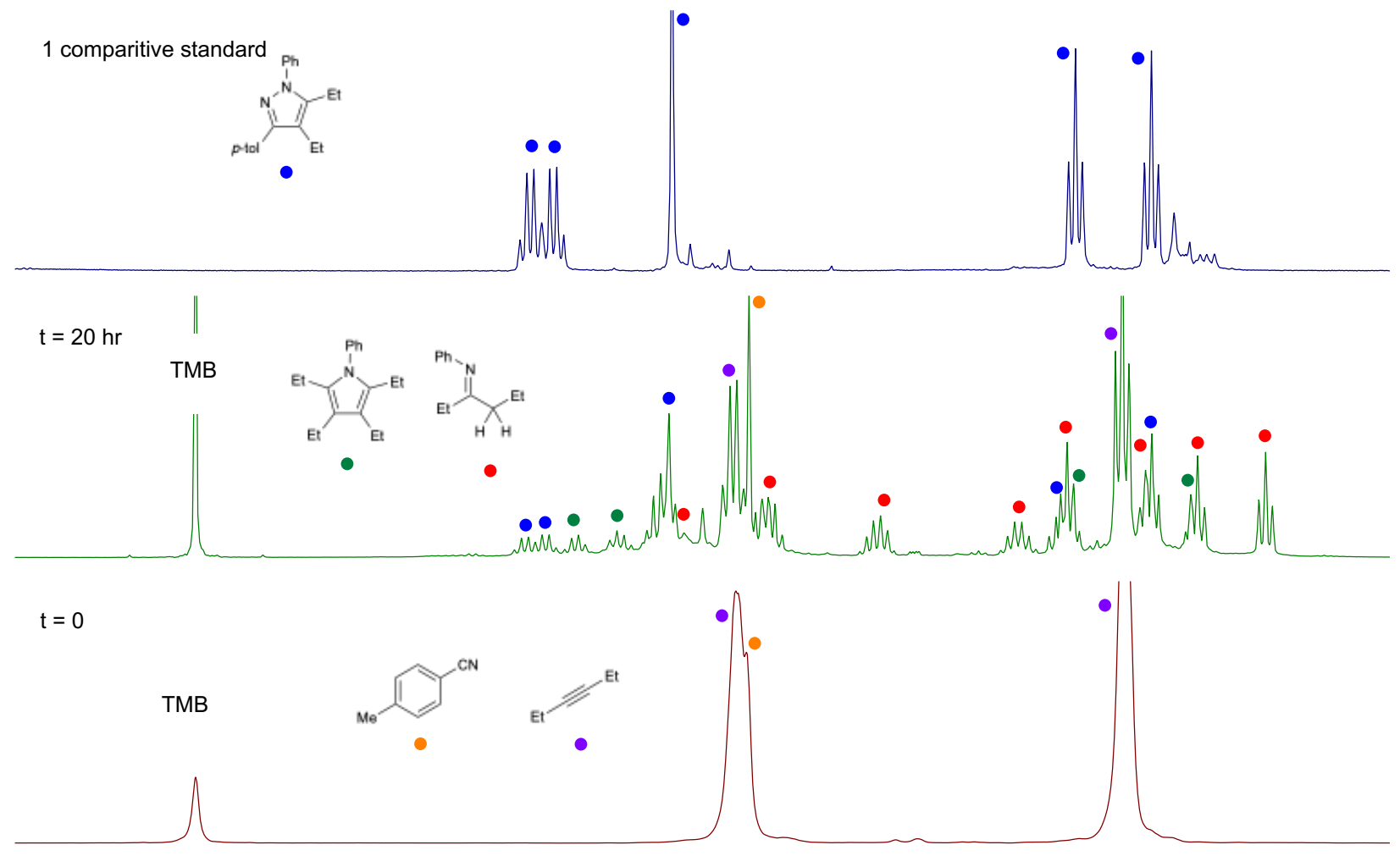

$\begin{array}{llllllllllllllllllllll}3.9 & 3.7 & 3.5 & 3.3 & 3.1 & 2.9 & 2.7 & 2.5 & 2.3 & 2.1 & 1.9 & 1.7 & 1.5 & 1.3 & 1.1 & 0.9 & 0.7 & 0.5 & 0 .\end{array}$

Figure S89. $\mathrm{t}=0$ (red), $\mathrm{t}=20 \mathrm{~h}$ (green) ${ }^{1} \mathrm{H}$ NMR spectra of the multicomponent coupling of azobenzene, 3-hexyne and $p$-tolunitrile catalyzed by $\mathrm{py}_{2} \mathrm{TiCl}_{2}(\mathrm{NPh})$ at $145{ }^{\circ} \mathrm{C}$ in $\mathrm{C}_{6} \mathrm{D}_{5} \mathrm{Br}$ compared to an independently synthesized standard of 1 (blue). 


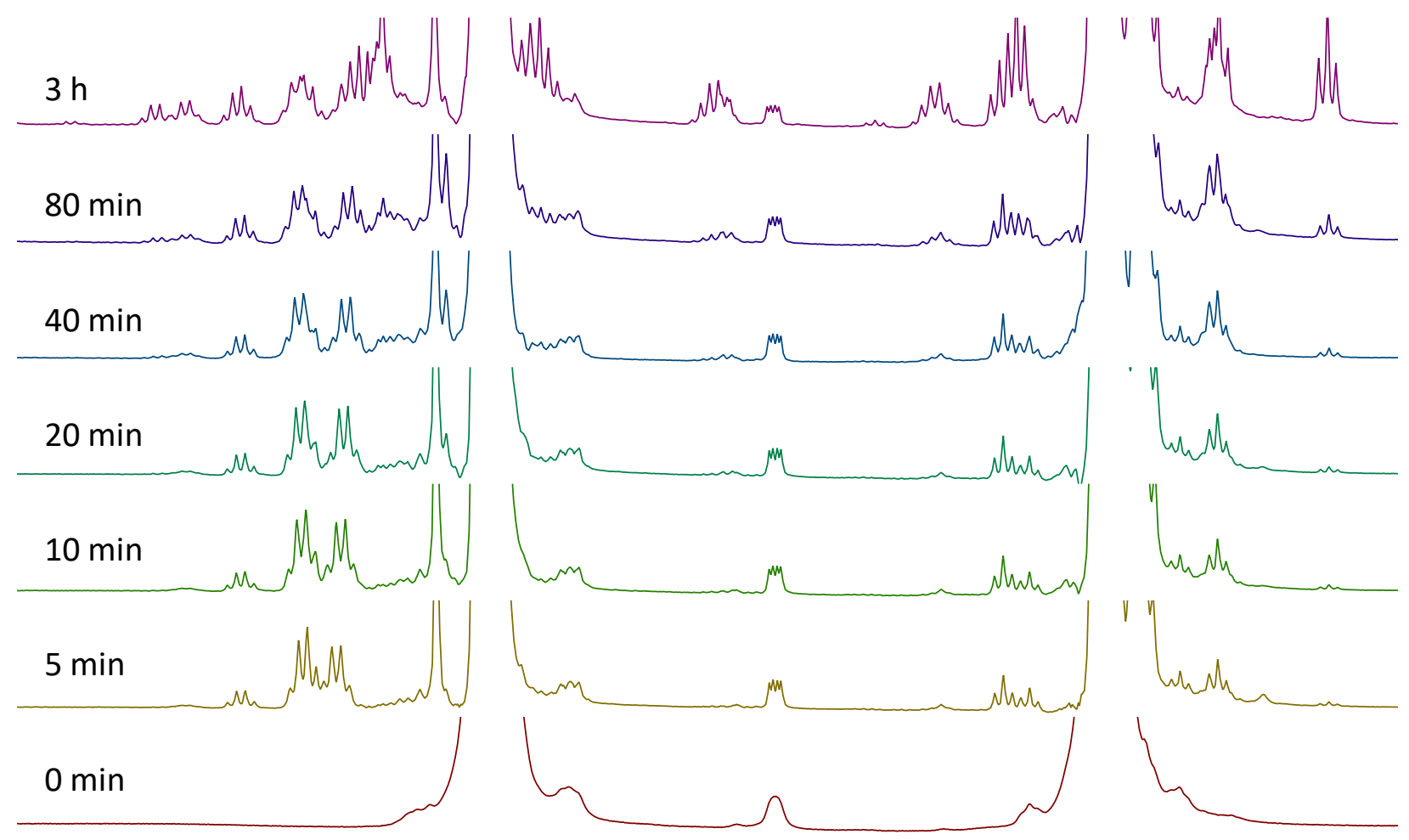

\section{$\begin{array}{llllllllllll}2.8 & 2.6 & 2.4 & 2.2 & 2.0 & 1.8 & \begin{array}{c}1.6 \\ \delta(\mathrm{ppm})\end{array} & 1.4 & 1.2 & 1.0 & 0.8 & 0.6\end{array}$}

Figure S90. Stacked 1H NMR spectra (alkyl region) of the multicomponent coupling of azobenzene, 3-hexyne and p-tolunitrile catalyzed by py2TiCl2(NPh) at $145{ }^{\circ} \mathrm{C}$ in $\mathrm{C}_{6} \mathrm{D}_{5} \mathrm{Br}$ over time.

\section{Turnover Experiment}

Procedure: In a NMR tube, $\left[\mathrm{py}_{2} \mathrm{TiCl}_{2}(\mathrm{NPh})\right]_{2}(0.013 \mathrm{mmol}, 47 \%), 1,2$-bis(4-(trifluoromethoxy)(phenyl)diazene (19.3 mg, $0.055 \mathrm{mmol}, 1$ equiv.) and $p$-tolunitrile (12.6 mg, $0.108 \mathrm{mmol}, 1.9$ equiv.)

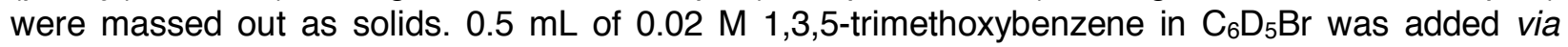
syringe, followed by 3-hexyne ( $35 \mu \mathrm{L}, 0.31 \mathrm{mmol}, 5.6$ equiv.). The tube was sealed and inverted several times to mix. A $t=0$ timepoint ${ }^{1} \mathrm{H}$ NMR was recorded, then the reaction was heated to $145^{\circ} \mathrm{C}$ for 21 hours, with time point spectra recorded every hour for the first 2 hours. Afterwards, a post reaction ${ }^{1} \mathrm{H}$ NMR was recorded. The reaction mixture was diluted with EtOAc $(\sim 1 \mathrm{~mL})$ to quench and filtered through a pipet plug of silica. The silica was washed with an additional $2 \mathrm{~mL}$ of EtOAc to extract all organics. GC-FID was used to obtain product yields, and peaks were identified by comparison of chromatograms to pure compounds (1,2-bis(4-(trifluoromethoxy)phenyl)diazene, $p$-tolunitrile, $\mathrm{N}$ phenylhexan-3-imine, 4,5-diethyl-N-phenyl-3-( $p$-tolyl)pyrazole, trimethoxybenzene, and 2,3,4,5tetraethyl-N-phenylpyrrole) or by relative retention times observed via GC-MS (N(trifluoromethoxy)phenyl)hexan-3-imine, 4,5-diethyl-N-(trifluoromethoxy)phenyl-3-(p-tolyl)pyrazole and 2,3,4,5-tetraethyl-N-(trifluoromethoxy)phenylpyrrole). 
Table S2. Diazene crossover experiment. ${ }^{a}$

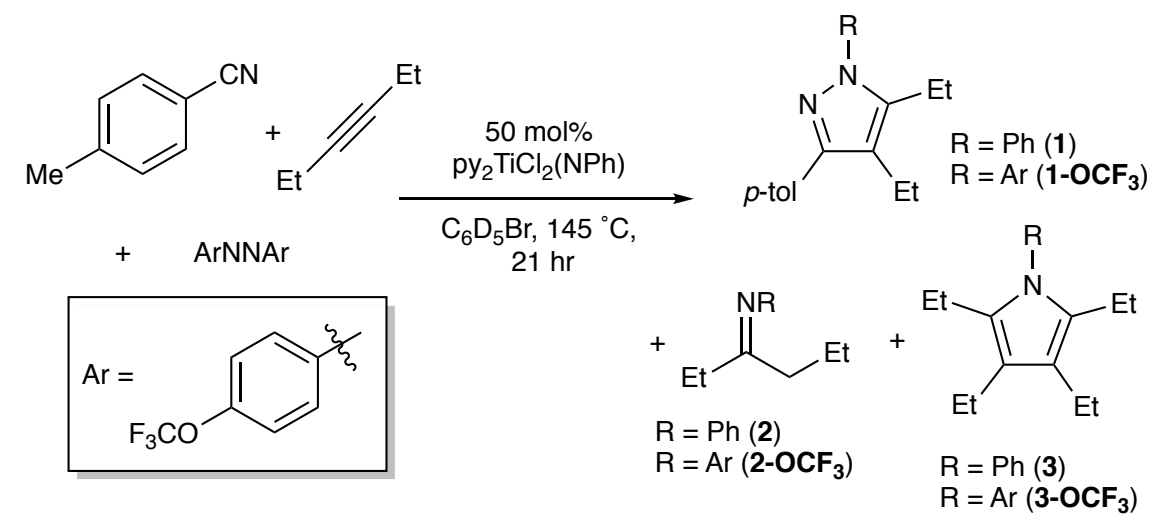

\begin{tabular}{l|ccc} 
Product & $\begin{array}{c}\text { \% Yield }(\mathrm{R} \\
=\mathrm{Ph})\end{array}$ & $\begin{array}{c}\text { \% Yield (R } \\
=\mathrm{Ar})\end{array}$ & $\begin{array}{c}\text { Ratio } \\
(\mathrm{Ar} / \mathrm{Ph})\end{array}$ \\
\hline Pyrazole & 11 & 16 & 1.4 \\
Imine & 3.7 & 60 & 16 \\
Pyrrole & 4.1 & 3.3 & 0.81
\end{tabular}

${ }^{a}$ Yields determined against 1,3,5-trimethoxybenzene internal standard by GC-FID with respect to mol Ti.

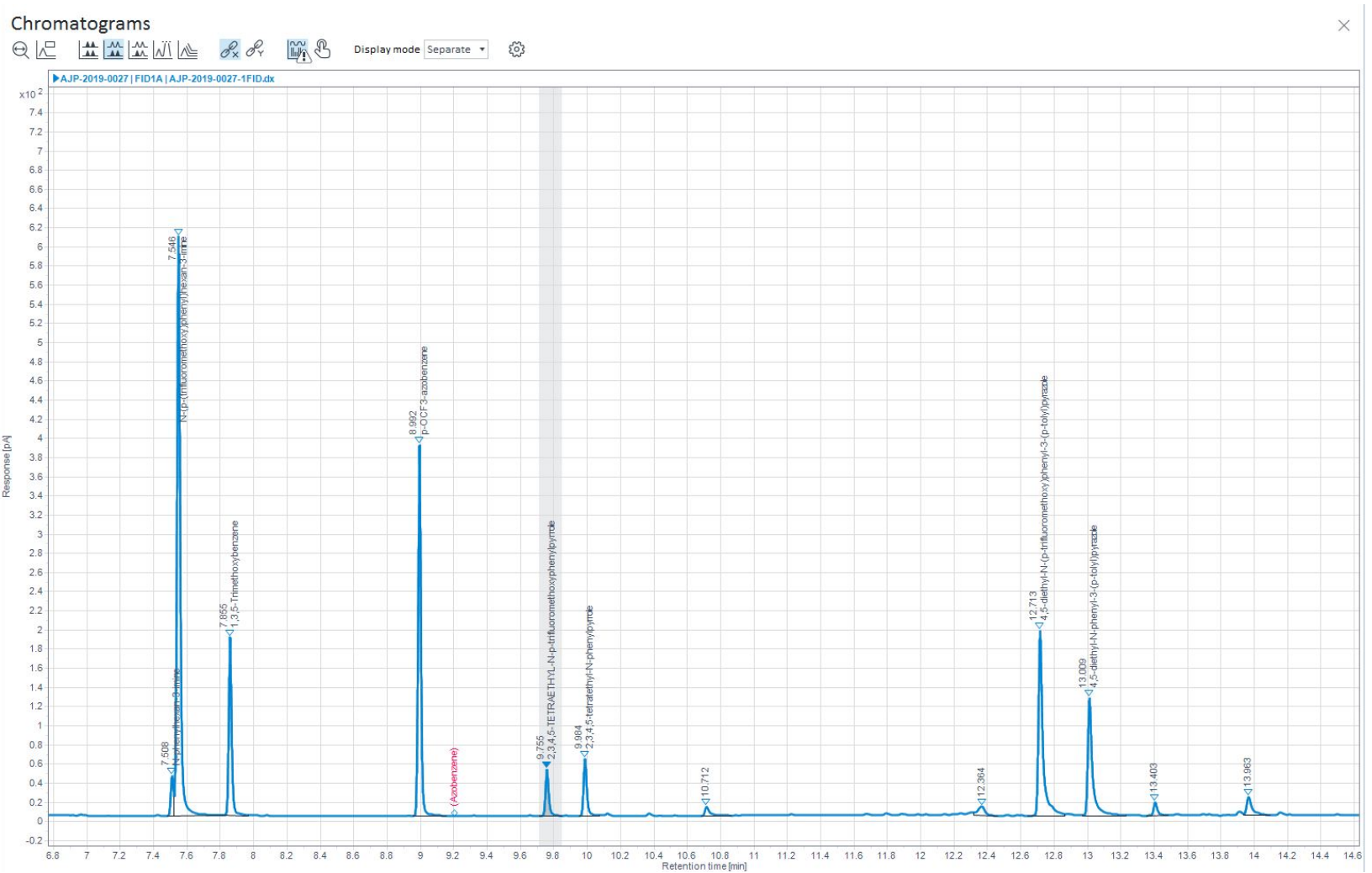

Figure S91. GC-FID chromatogram characterizing the diazene turnover experiment. 


\section{$\mathrm{Li}_{2} \mathrm{ADA}^{\mathrm{Et}}$ oxidation with $\mathrm{PhICl}_{2}$}

Procedure: $\mathrm{Li}_{2} \mathrm{ADA} \mathrm{Et}$ - 3THF (10.0 mg, $0.0197 \mathrm{mmol}, 1$ equiv.) was massed out in a vial and dissolved in $0.5 \mathrm{~mL} \mathrm{C}_{6} \mathrm{D}_{6}$. $\mathrm{PhICl}_{2}(6.4 \mathrm{mg}, 0.0232 \mathrm{mmol}, 1.18$ equiv.) was massed out in an NMR tube, and the $\mathrm{Li}_{2} \mathrm{ADA}^{\mathrm{Et}}$ solution was added to the tube, capped, and inverted to mix. A ${ }^{1} \mathrm{H}$ NMR spectrum was recorded.

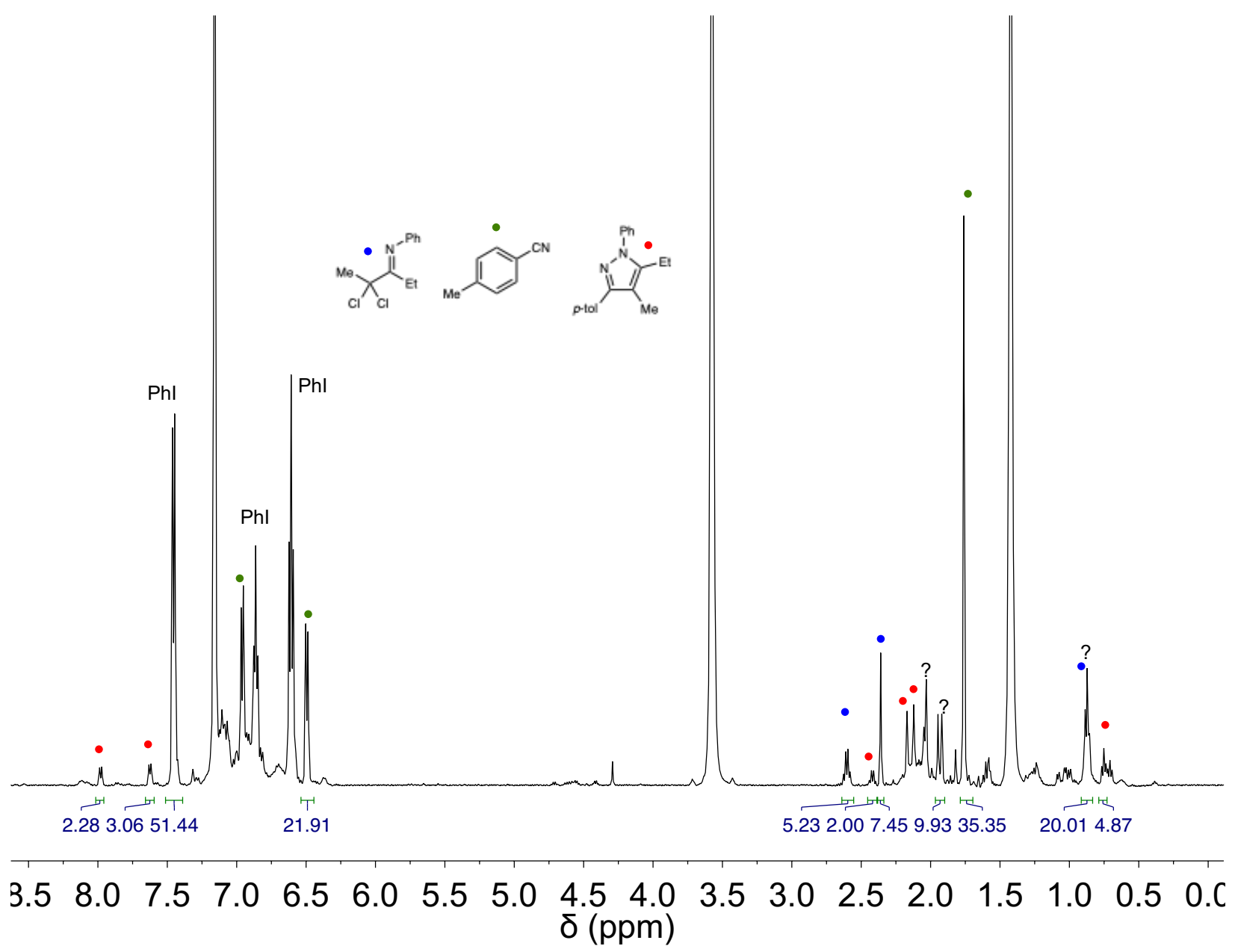

Figure S92. ${ }^{1} \mathrm{H}$ NMR spectrum of the reaction between $\mathrm{Li}_{2} \mathrm{ADA}^{\mathrm{Ph}} \cdot 3 \mathrm{THF}$ and $\mathrm{PhICl}_{2}$ in $\mathrm{C}_{6} \mathrm{D}_{6}$. 


\section{Thermolysis of $7 \mathrm{a}$ at $145^{\circ} \mathrm{C}$}<smiles>CC1=C(c2ccccc2)N(c2ccccc2)[Te](Cl)(C(Br)(Br)Br)(C(Br)(Br)c2ccccc2)N=C1c1ccc(C)cc1</smiles>

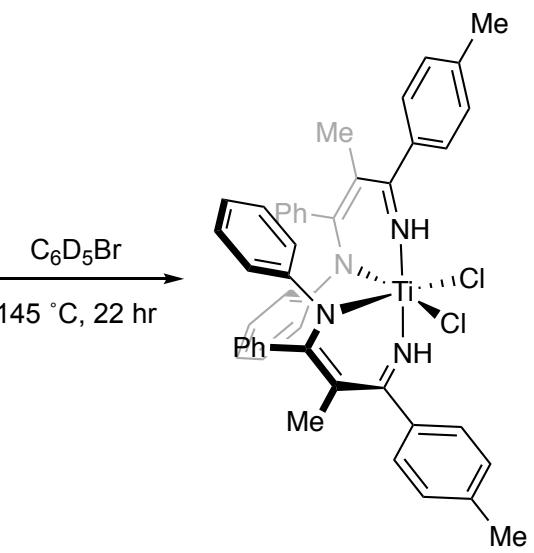

Procedure: $7 a(8.8 \mathrm{mg}, 0.015 \mathrm{mmol})$ was placed in an NMR tube along with $0.5 \mathrm{~mL}$ of $\mathrm{C}_{6} \mathrm{D}_{5} \mathrm{Br}$. The NMR tube was sealed and heated to $145^{\circ} \mathrm{C}$ for 22 hours. Afterwards, a ${ }^{1} \mathrm{H}$ NMR spectrum was recorded.

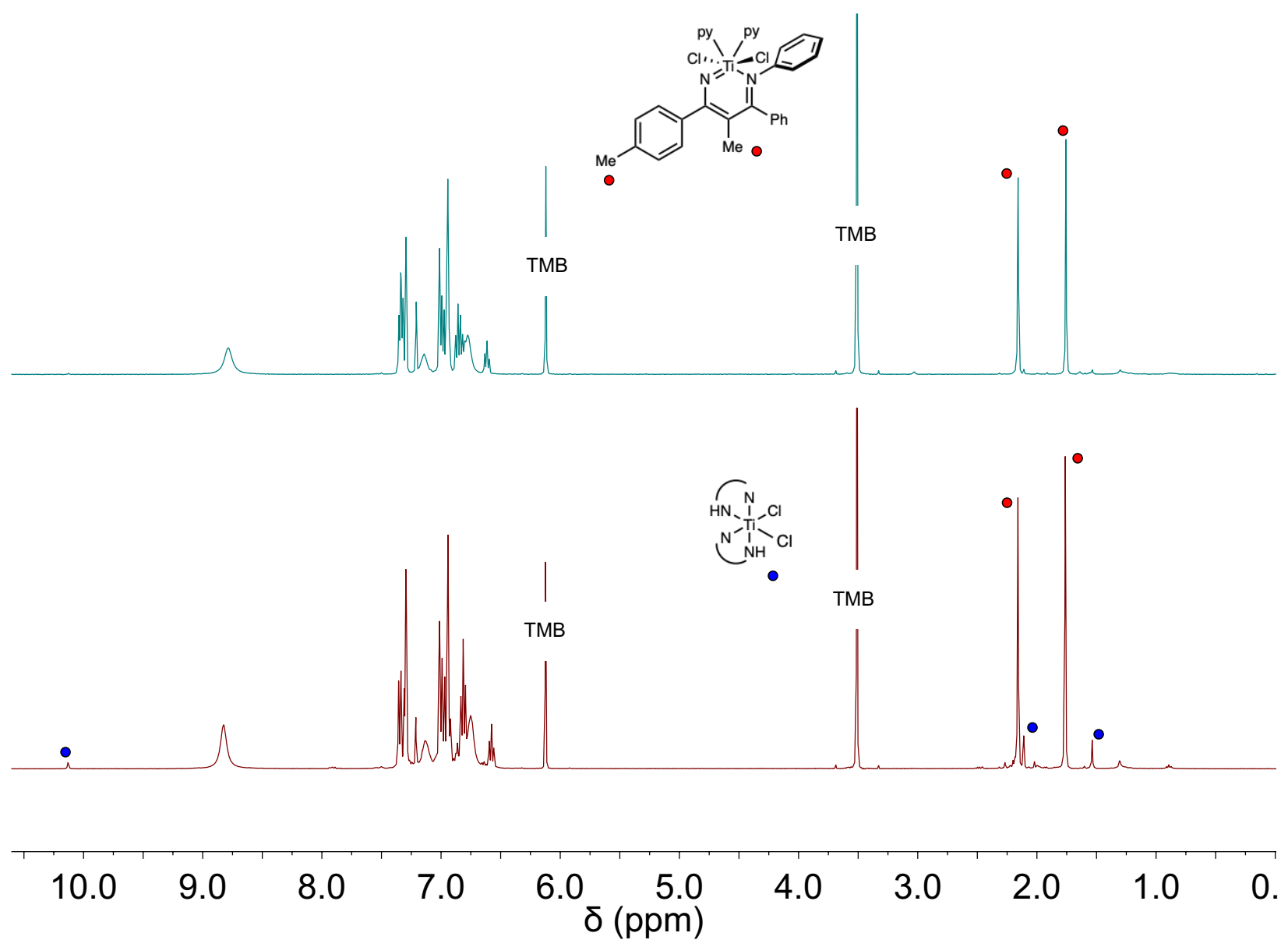

Figure S93. Stacked ${ }^{1} \mathrm{H}$ NMR spectra characterizing the attempted thermolysis of $7 \mathrm{a}$ in $\mathrm{C}_{6} \mathrm{D}_{5} \mathrm{Br}$. Top (teal trace): $\mathrm{t}=0$. Bottom (red trace): $\mathrm{t}=22 \mathrm{~h}$. 


\section{7 a decomposition at $145^{\circ} \mathrm{C}$ in the presence of azobenzene}

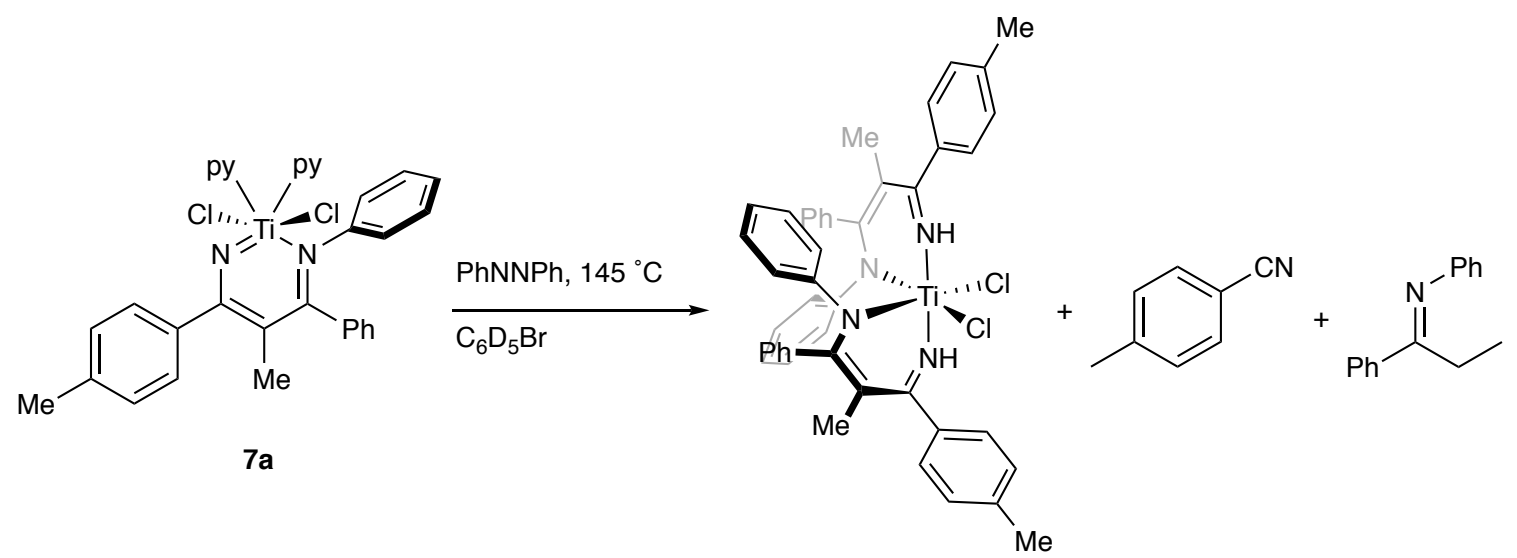

Procedure: To an NMR tube was added $7 \mathrm{a}(5.9 \mathrm{mg}, 0.0098 \mathrm{mmol}, 1$ equiv.) and azobenzene (4.0 $\mathrm{mg}, 0.022 \mathrm{mmol}, 2.2$ equiv.). $0.5 \mathrm{~mL}$ of $\mathrm{C}_{6} \mathrm{D}_{5} \mathrm{Br}$ was added, and the mixture was heated to $145^{\circ} \mathrm{C}$ for 22 hours. Afterwards, a ${ }^{1} \mathrm{H}$ NMR spectrum was recorded.
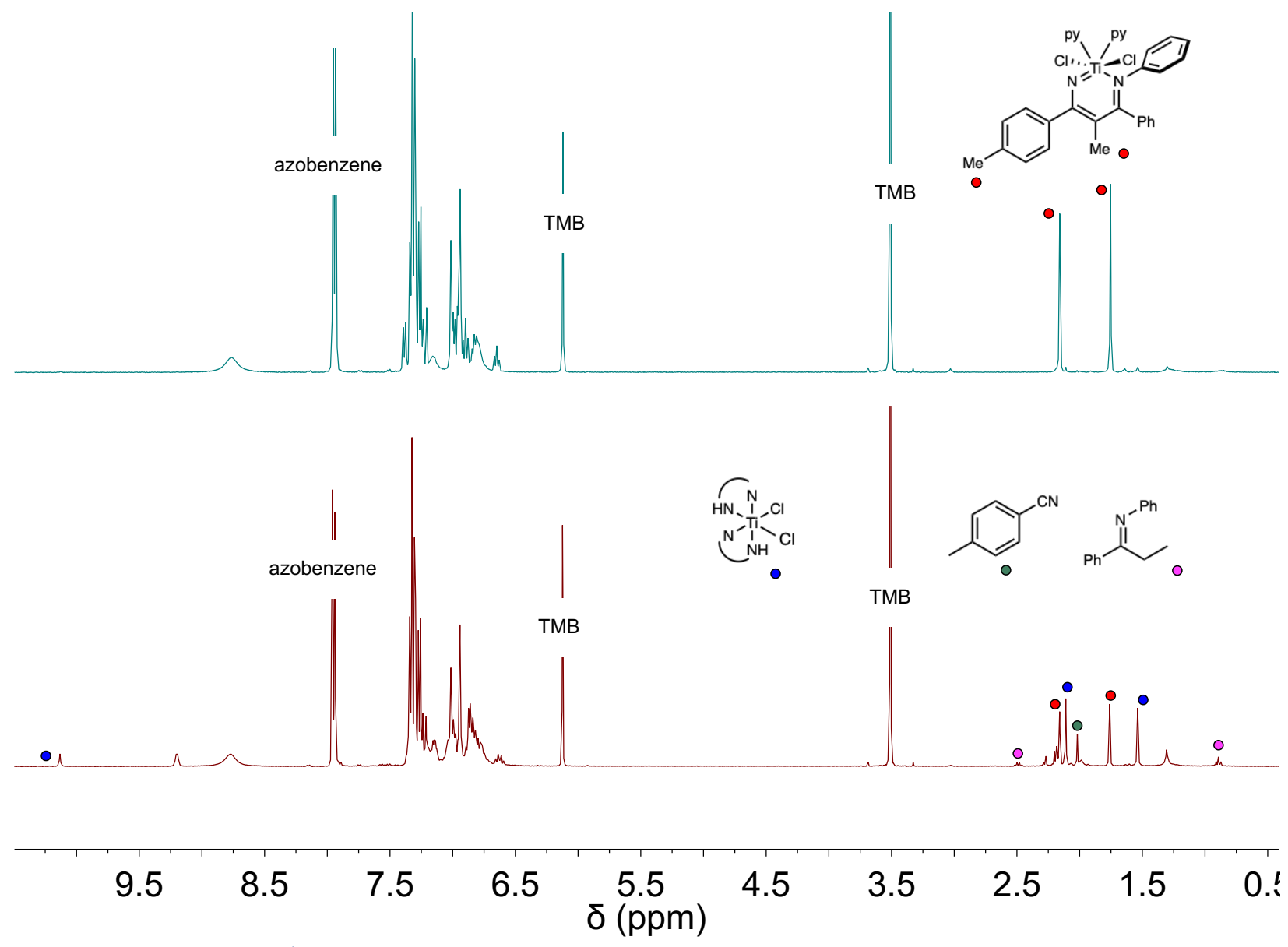

Figure S94. Stacked ${ }^{1} \mathrm{H}$ NMR spectra characterizing the attempted thermolysis of $7 \mathrm{a}$ in the presence of azobenzene in $\mathrm{C}_{6} \mathrm{D}_{5} \mathrm{Br}$. Top (teal trace): $\mathrm{t}=0$. Bottom (red trace): $\mathrm{t}=22 \mathrm{~h}$. 


\section{Reaction of 8 a with $\mathrm{TiCl}_{3}(\mathrm{THF})_{3}$}

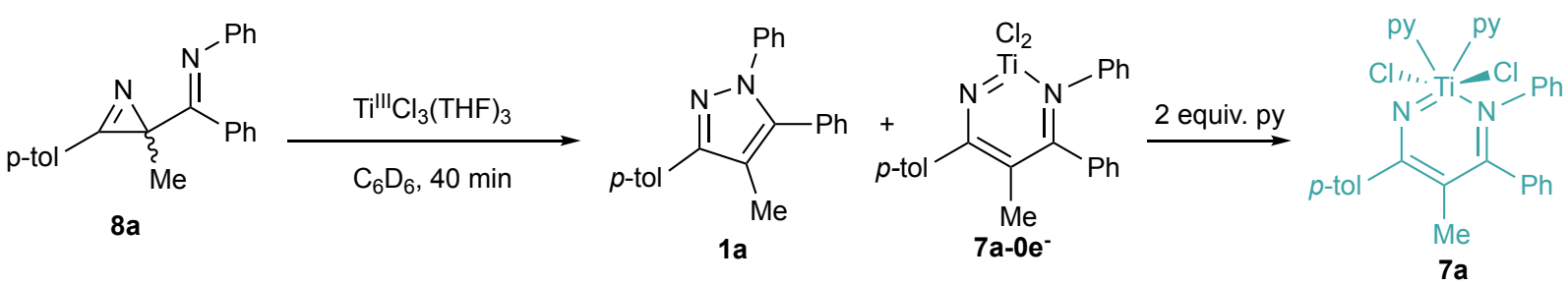

Procedure: To a stirring suspension of $\mathrm{TiCl}_{3}(\mathrm{THF})_{3}\left(13.2 \mathrm{mg}, 0.0356 \mathrm{mmol}, 1\right.$ equiv.) in $\mathrm{C}_{6} \mathrm{D}_{6}$ $(\sim 0.25 \mathrm{ml})$ was added a solution of $8 \mathrm{a}\left(12.0 \mathrm{mg}, 0.037 \mathrm{mmol}, 1.0\right.$ equiv.) in $\mathrm{C}_{6} \mathrm{D}_{6}$ to immediately give a dark maroon homogeneous solution. The solution was transferred to an NMR tube, and its spectrum was recorded. The tube was then brought back into the glovebox, where a drop of pyridine ( 3-4 mg, 0.04-0.05 mmol) was added. The tube was resealed and its ${ }^{1} \mathrm{H}$ NMR spectrum was recorded.

after addition of pyridine
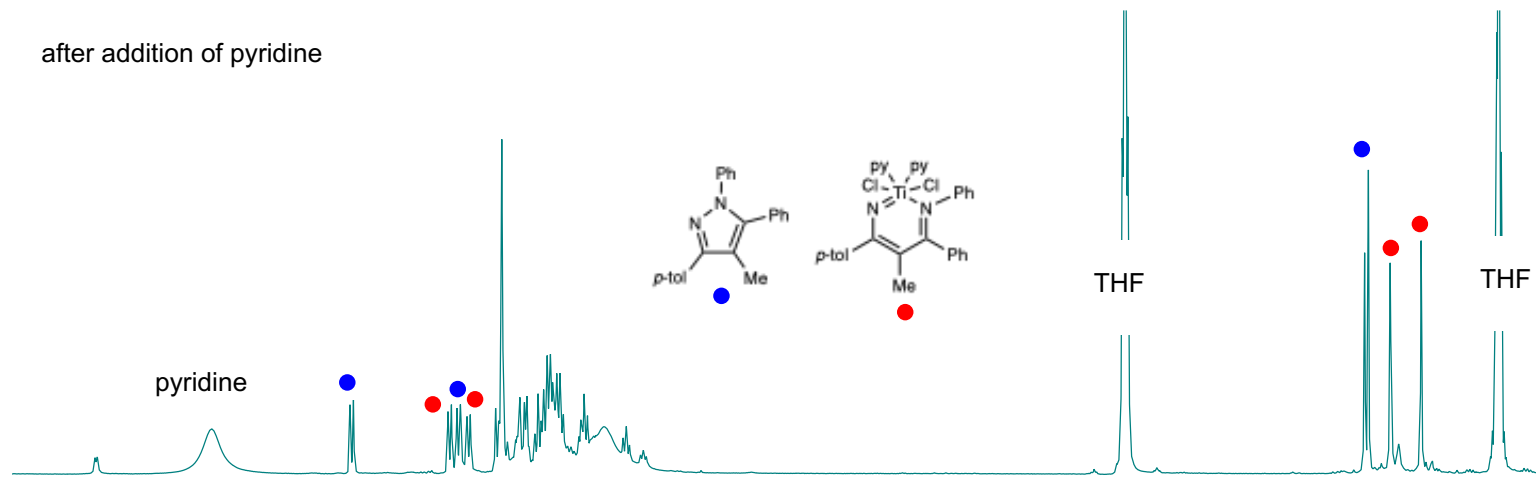

immediately after mixing

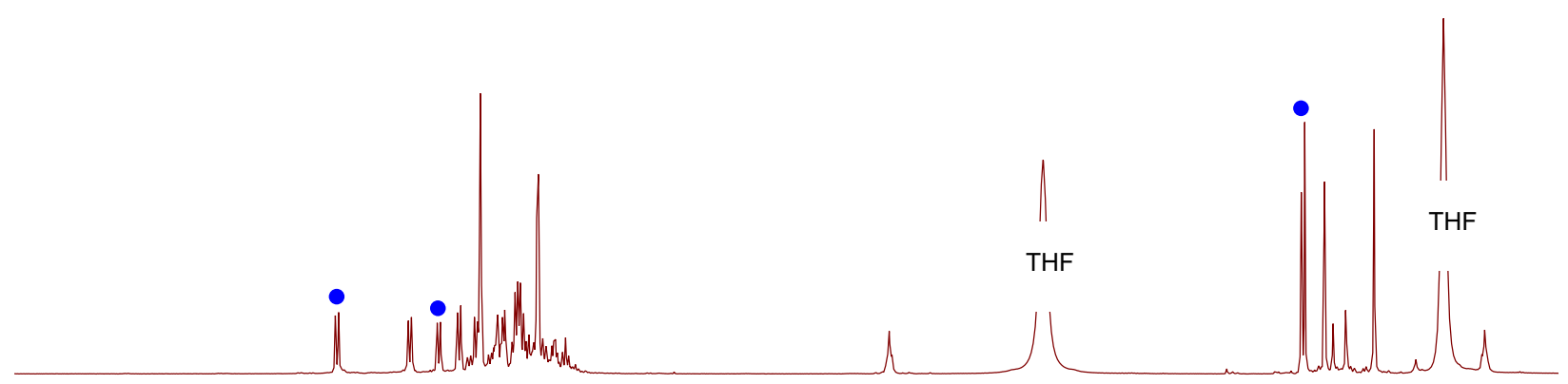

\section{$\begin{array}{llllllllllllllllll}9.5 & 9.0 & 8.5 & 8.0 & 7.5 & 7.0 & 6.5 & 6.0 & 5.5 & 5.0 & 4.5 & 4.0 & 3.5 & 3.0 & 2.5 & 2.0 & 1.5 & 1.0\end{array}$ $\delta(\mathrm{ppm})$}

Figure S95. Stacked ${ }^{1} \mathrm{H}$ NMR spectra of the reaction between $8 \mathrm{a}$ and $\mathrm{TiCl}_{3}(\mathrm{THF})_{3}$ in $\mathrm{C}_{6} \mathrm{D}_{6}$. Bottom (red trace): immediately after mixing. Top (teal trace): after the addition of pyridine. 


\section{Reaction of $\mathbf{8 a}$ with $\mathrm{TiCl}_{3}(\mathrm{THF})_{3}$ (NMR yields)}

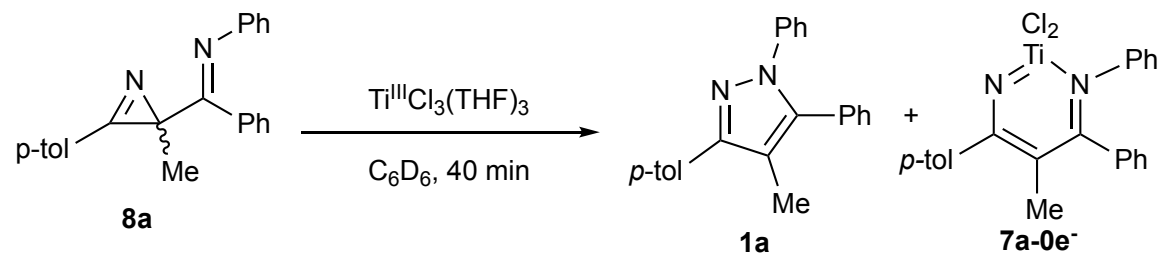

Procedure: A solution of TMB (1.2 $\mathrm{mg}, 0.0071 \mathrm{mmol})$ and $8 \mathrm{a}(6.1 \mathrm{mg}, 0.019 \mathrm{mmol}, 1$ equiv.) in $\mathrm{C}_{6} \mathrm{D}_{6}(0.5 \mathrm{~mL})$ was prepared, and its ${ }^{1} \mathrm{H}$ NMR spectrum recorded. This solution was then added to solid $\mathrm{TiCl}_{3}(\mathrm{THF})_{3}(6.7 \mathrm{mg}, 0.018 \mathrm{mmol}, 1.1$ equiv.), immediately giving a dark maroon homogeneous solution. The solution was transferred to an NMR tube, and its spectrum was recorded.

$t=0$

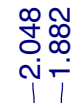

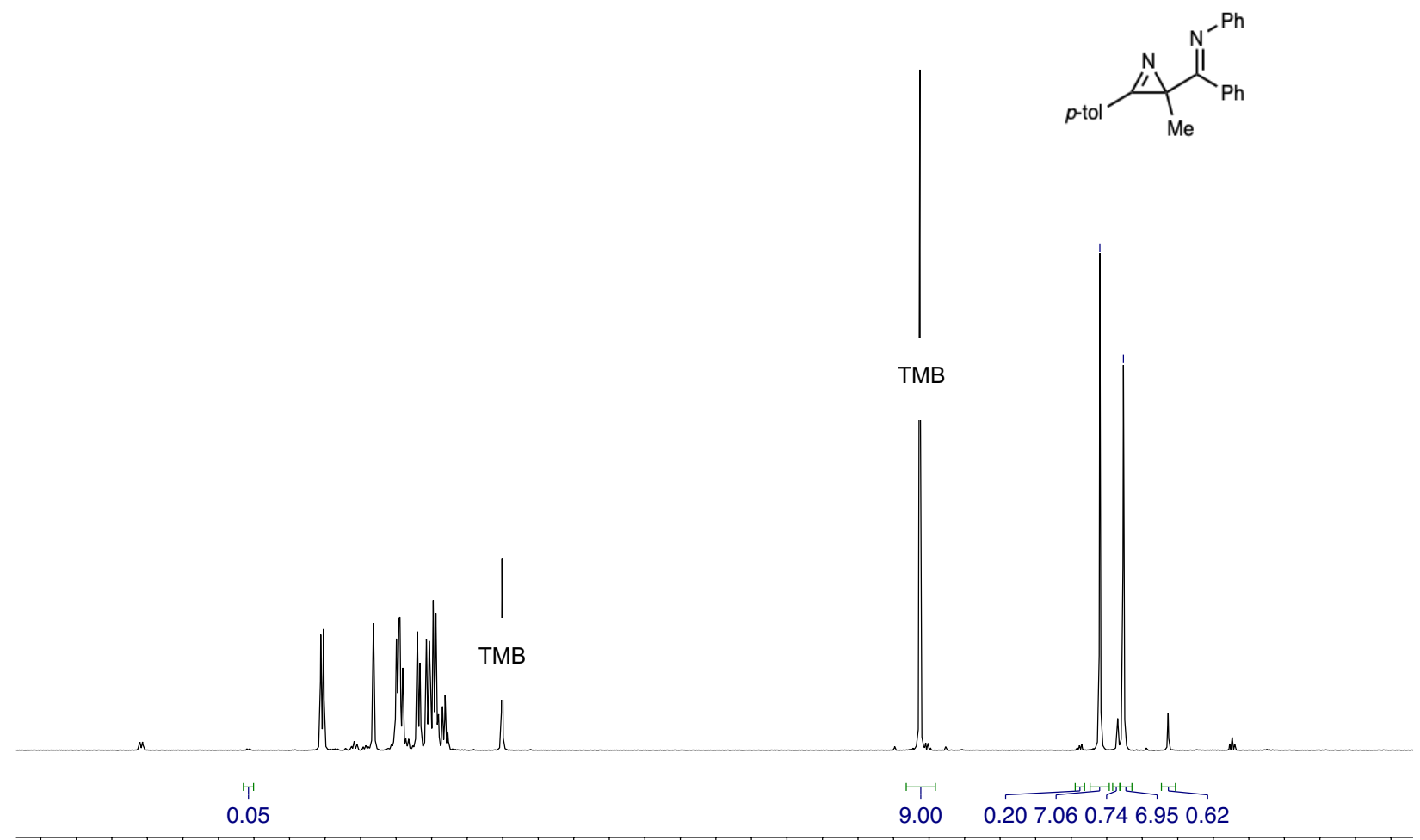

$\begin{array}{llllllllllllllllllll}9.5 & 9.0 & 8.5 & 8.0 & 7.5 & 7.0 & 6.5 & 6.0 & 5.5 & 5.0 & 4.5 & 4.0 & 3.5 & 3.0 & 2.5 & 2.0 & 1.5 & 1.0 & 0.5 & 0.0\end{array}$ $\delta(\mathrm{ppm})$

Figure S96. ${ }^{1} \mathrm{H}$ NMR spectrum of $8 \mathrm{a}$ and $\mathrm{TMB}$ in $\mathrm{C}_{6} \mathrm{D}_{6}$ before addition to $\mathrm{TiCl}_{3}(\mathrm{THF})_{3}$. 

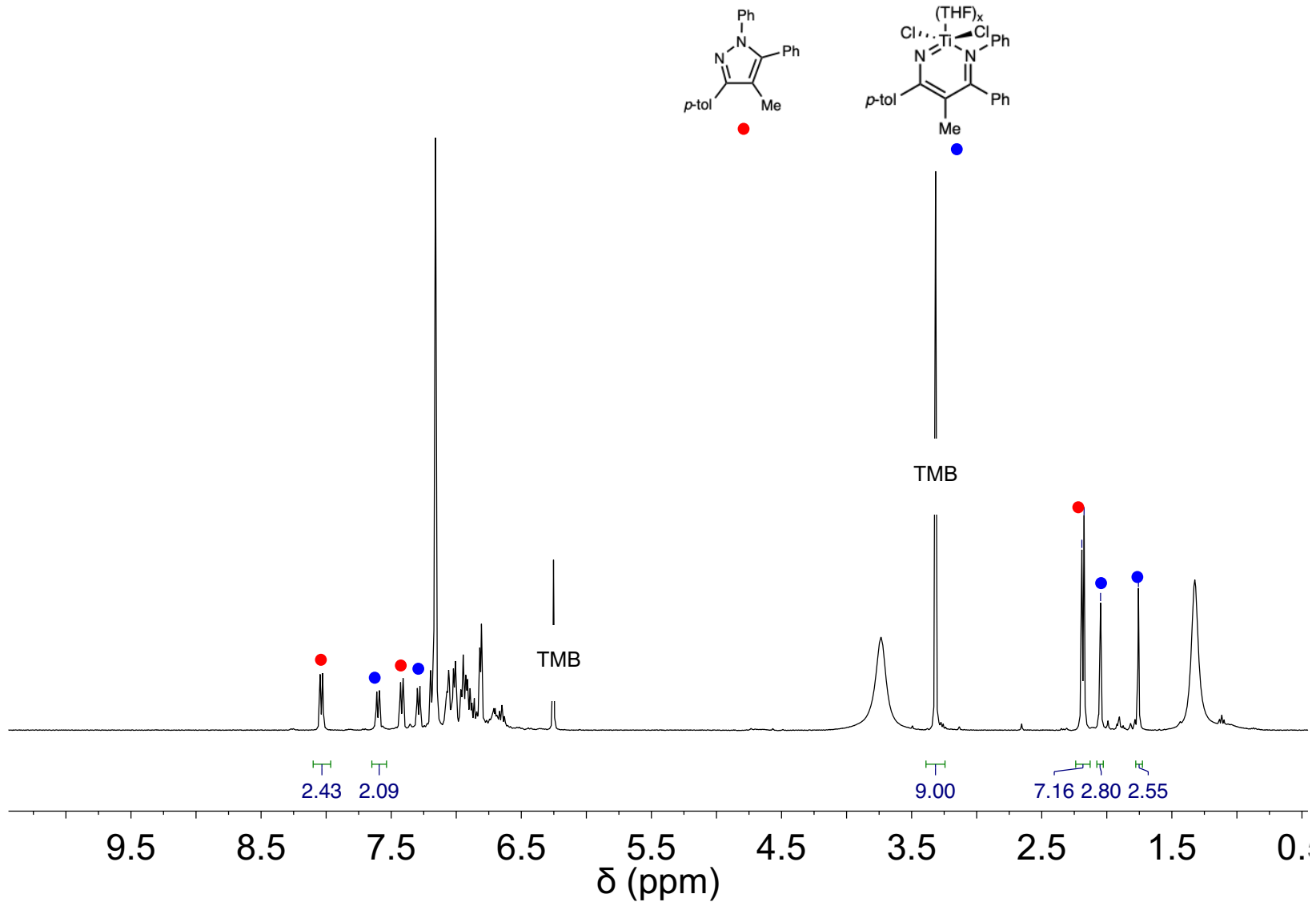

Figure S97. ${ }^{1} \mathrm{H}$ NMR spectrum after addition of $8 \mathbf{a}$ and $\mathrm{TMB}$ to $\mathrm{TiCl}_{3}(\mathrm{THF})_{3}$ in $\mathrm{C}_{6} \mathrm{D}_{6}$.

\section{Reaction of 8 with $\mathrm{TiCl}_{4}(\mathrm{THF})_{2}$ (room temperature)}

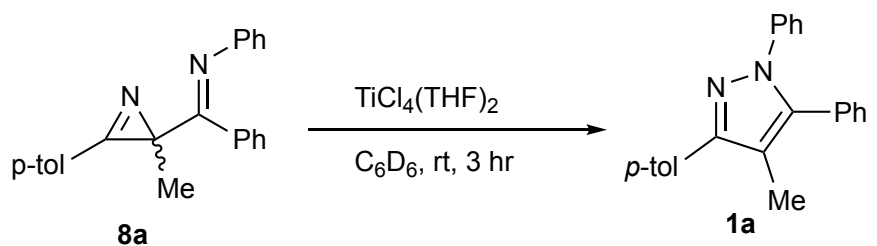

Procedure: A solution of 8 (2.5 mg, $0.0077 \mathrm{mmol}, 1$ equiv.) in $\mathrm{C}_{6} \mathrm{D}_{6}(\sim 0.5 \mathrm{~mL})$ was added to solid $\mathrm{TiCl}_{4}(\mathrm{THF})_{2}(5.5 \mathrm{mg}, 0.016 \mathrm{mmol}, 2.1$ equiv.), giving a yellow homogeneous solution. The solution was transferred to an NMR tube, and the reaction was monitored by ${ }^{1 \mathrm{H}}$ NMR spectroscopy. 

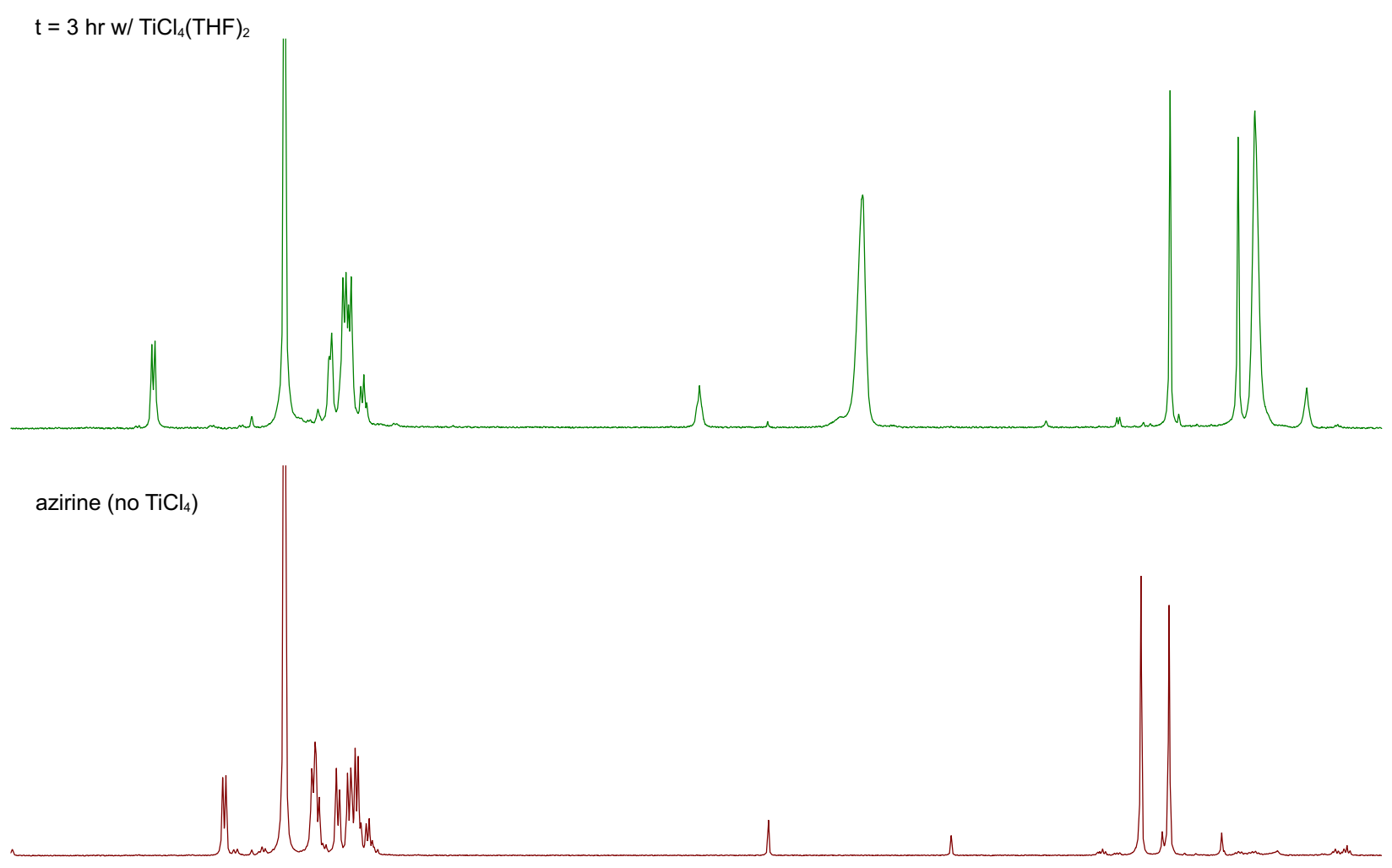

\section{$\begin{array}{llllllllllllllll}8.5 & 8.0 & 7.5 & 7.0 & 6.5 & 6.0 & 5.5 & \begin{array}{c}5.0 \\ \delta(\mathrm{ppm})\end{array} & 4.5 & 4.0 & 3.5 & 3.0 & 2.5 & 2.0 & 1.5 & 1.0\end{array}$}

Figure S98. Stacked ${ }^{1} \mathrm{H}$ NMR spectra characterizing the addition of azirine $\mathbf{8 a}$ to $\mathrm{TiCl}_{4}(\mathrm{THF})_{2}$ in $\mathrm{C}_{6} \mathrm{D}_{6}$. Bottom (red trace): ${ }^{1} \mathrm{H}$ NMR spectrum of $8 \mathrm{a}$ prior to $\mathrm{TiCl}_{4}(\mathrm{THF})_{2}$ addition. Top (green trace): $\mathrm{t}=3 \mathrm{~h}$ time point after $\mathrm{TiCl}_{4}(\mathrm{THF})_{2}$ addition.

\section{Reaction of $8 \mathrm{a}$ with $\mathrm{TiCl}_{4}(\mathrm{THF})_{2}\left(50{ }^{\circ} \mathrm{C}\right)$}<smiles>CC(C)(C)C1=NC1(O)C(=Nc1ccccc1)c1ccccc1</smiles>

Procedure: A solution of $8 \mathrm{a}\left(4.7 \mathrm{mg}, 0.014 \mathrm{mmol}, 1\right.$ equiv.) in $\mathrm{C}_{6} \mathrm{D}_{6}(\sim 0.5 \mathrm{~mL})$ was added to solid $\mathrm{TiCl}_{4}(\mathrm{THF})_{2}$ (5.5 mg, $0.016 \mathrm{mmol}, 1.2$ equiv.), giving a yellow homogeneous solution. The solution was transferred to an NMR tube, and the tube was heated to $50{ }^{\circ} \mathrm{C}$ in an oil bath. The reaction was monitored by ${ }^{1} \mathrm{H}$ NMR spectroscopy. 


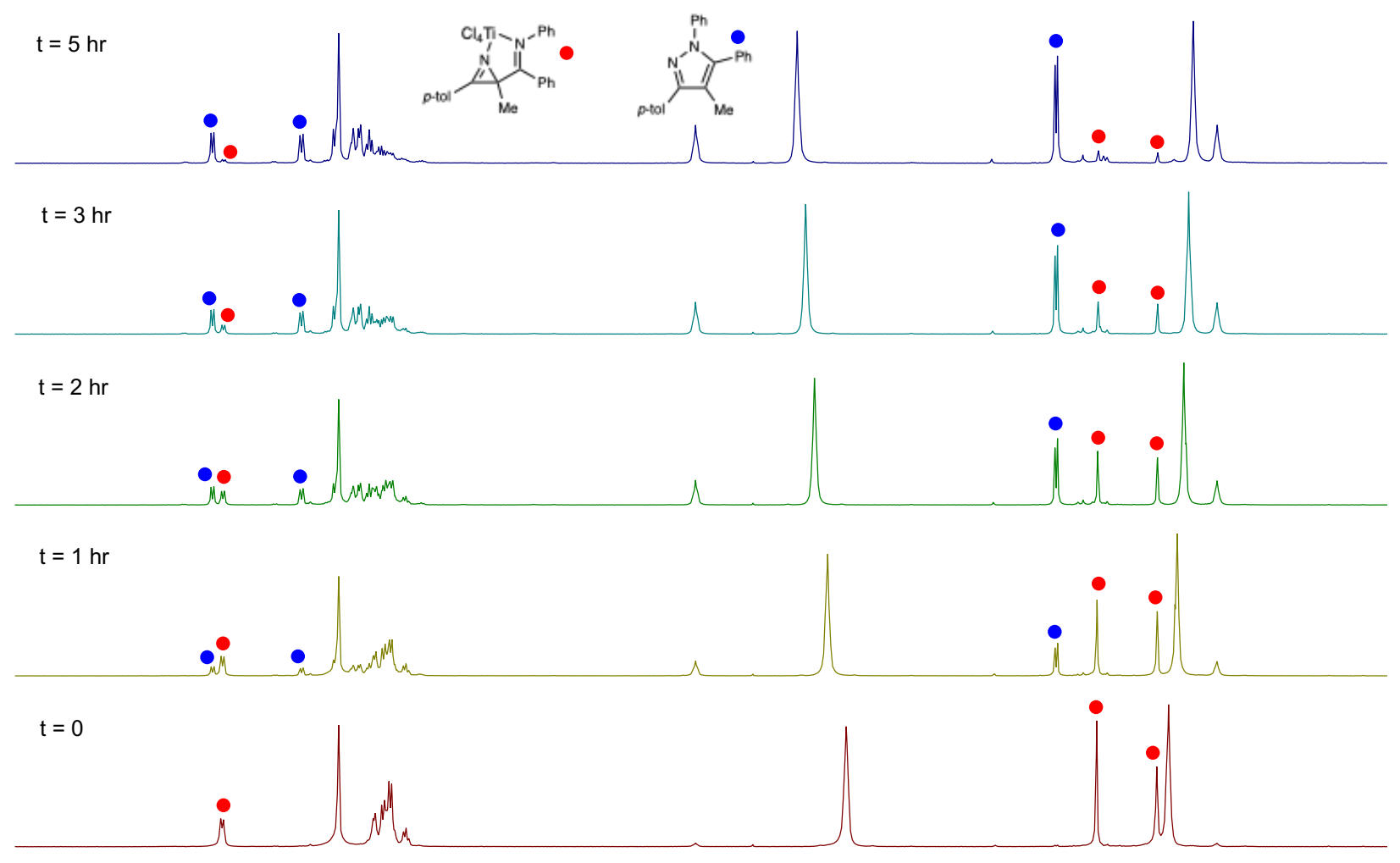

$\begin{array}{lllllllllllllllllll}9.0 & 8.5 & 8.0 & 7.5 & 7.0 & 6.5 & 6.0 & 5.5 & 5.0 & 4.5 & 4.0 & 3.5 & 3.0 & 2.5 & 2.0 & 1.5 & 1.0 & 0.5 & 0 . C\end{array}$ $\delta(\mathrm{ppm})$

Figure S99. Stacked ${ }^{1} \mathrm{H}$ NMR spectra characterizing the reaction of $8 \mathrm{a}$ and $\mathrm{TiCl}_{4}(\mathrm{THF})_{2}$ at $50{ }^{\circ} \mathrm{C}$ in $\mathrm{C}_{6} \mathrm{D}_{6}$ over 3 hours.

\section{Thermolysis of $10 \mathrm{a}$ to $1 \mathrm{a}$ and $\mathrm{Cp}_{2} \mathrm{TiCl}_{2}$}

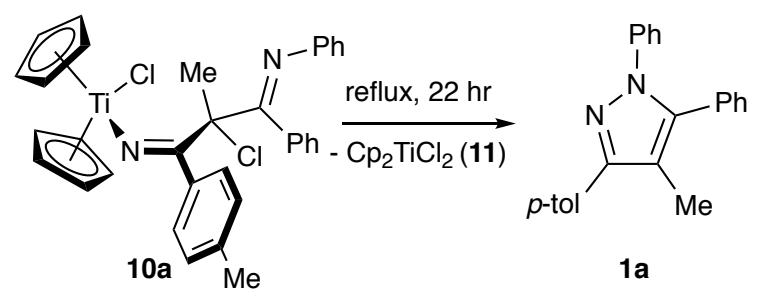

Procedure: A freshly prepared sample of $10 \mathrm{a}$ (via the oxidation of $9 \mathrm{a}(8.5 \mathrm{mg}, 0.017 \mathrm{mmol}, 1$ equiv.) with $\mathrm{PhICl}_{2}$ (4.8 $\mathrm{mg}, 0.017 \mathrm{mmol}, 1.0$ equiv.)) was heated from $50-80{ }^{\circ} \mathrm{C}$ overnight. The reaction was monitored by ${ }^{1} \mathrm{H}$ NMR spectroscopy. 


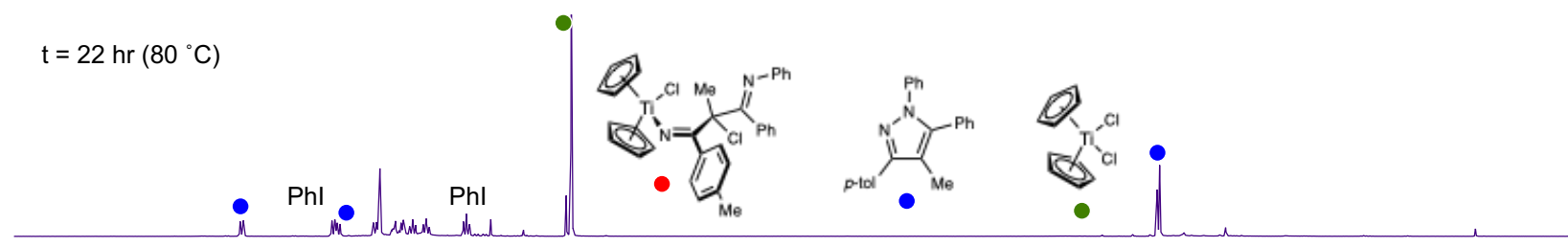

$\mathrm{t}=4 \mathrm{hr}\left(70^{\circ} \mathrm{C}\right)$

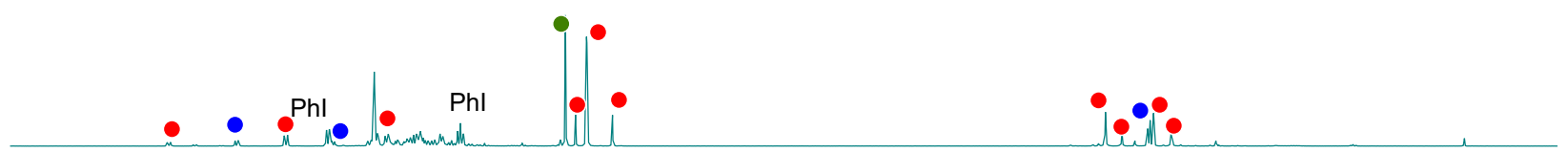

$\mathrm{t}=2 \mathrm{hr}\left(50^{\circ} \mathrm{C}\right)$
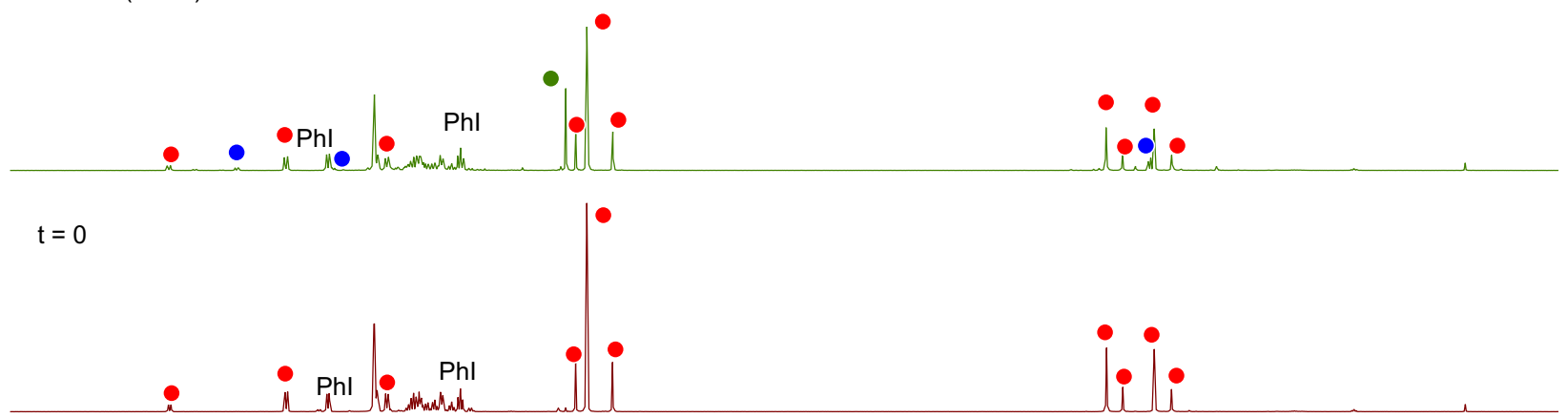

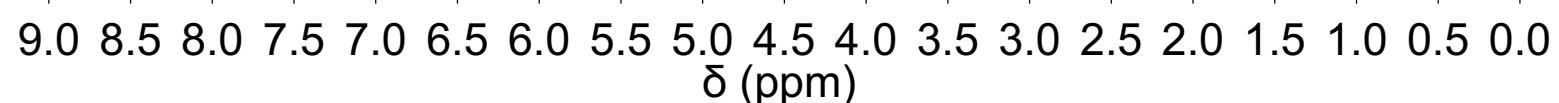

Figure S100. Stacked ${ }^{1} \mathrm{H}$ NMR spectra characterizing the thermolysis of 10 a to 1a over time.

\section{One-pot conversion of $\mathbf{8 a}$ to $1 \mathbf{a}$ via titanocene intermediates $\mathbf{9 a}$} and $10 a$

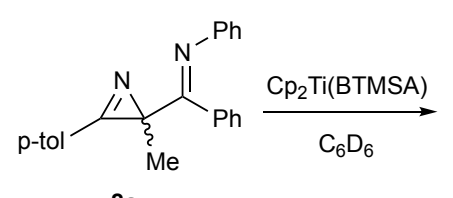

$8 a$

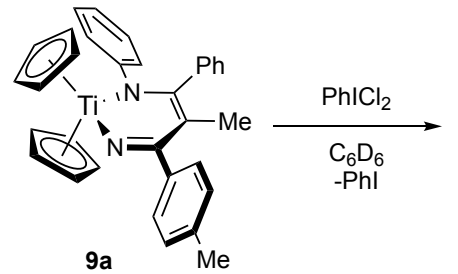

9 a

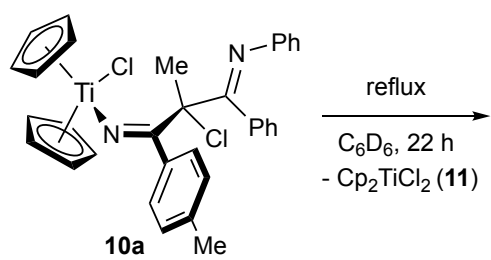<smiles>Cc1c(Cl)nn(-c2ccccc2)c1-c1ccccc1</smiles>

Procedure: Azirine 8a (8.7 mg, $0.027 \mathrm{mmol}, 1$ equiv.) and TMB $(0.9 \mathrm{mg}, 0.005 \mathrm{mmol})$ in $\mathrm{C}_{6} \mathrm{D}_{6}(0.5$ $\mathrm{mL}$ ) were added to an NMR tube containing solid $\mathrm{Cp}_{2} \mathrm{Ti}(B T M S A)(9.4 \mathrm{mg}, 0.027 \mathrm{mmol}, 1.0$ equiv.), immediately furnishing a deep red solution. A $1 \mathrm{H}$ NMR spectrum was recorded. The tube was brought back into the glovebox, where $\mathrm{PhICl}_{2}(7.6 \mathrm{mg}, 0.028 \mathrm{mmol}, 1.0$ equiv.) was added, which upon full dissolution rapidly gave a bright yellow-orange solution. Another ${ }^{1} \mathrm{H}$ NMR spectrum was recorded. The tube was then placed in an $80{ }^{\circ} \mathrm{C}$ oil bath overnight $(22 \mathrm{~h})$, and a final time point ${ }^{1} \mathrm{H}$ NMR spectrum was recorded. 

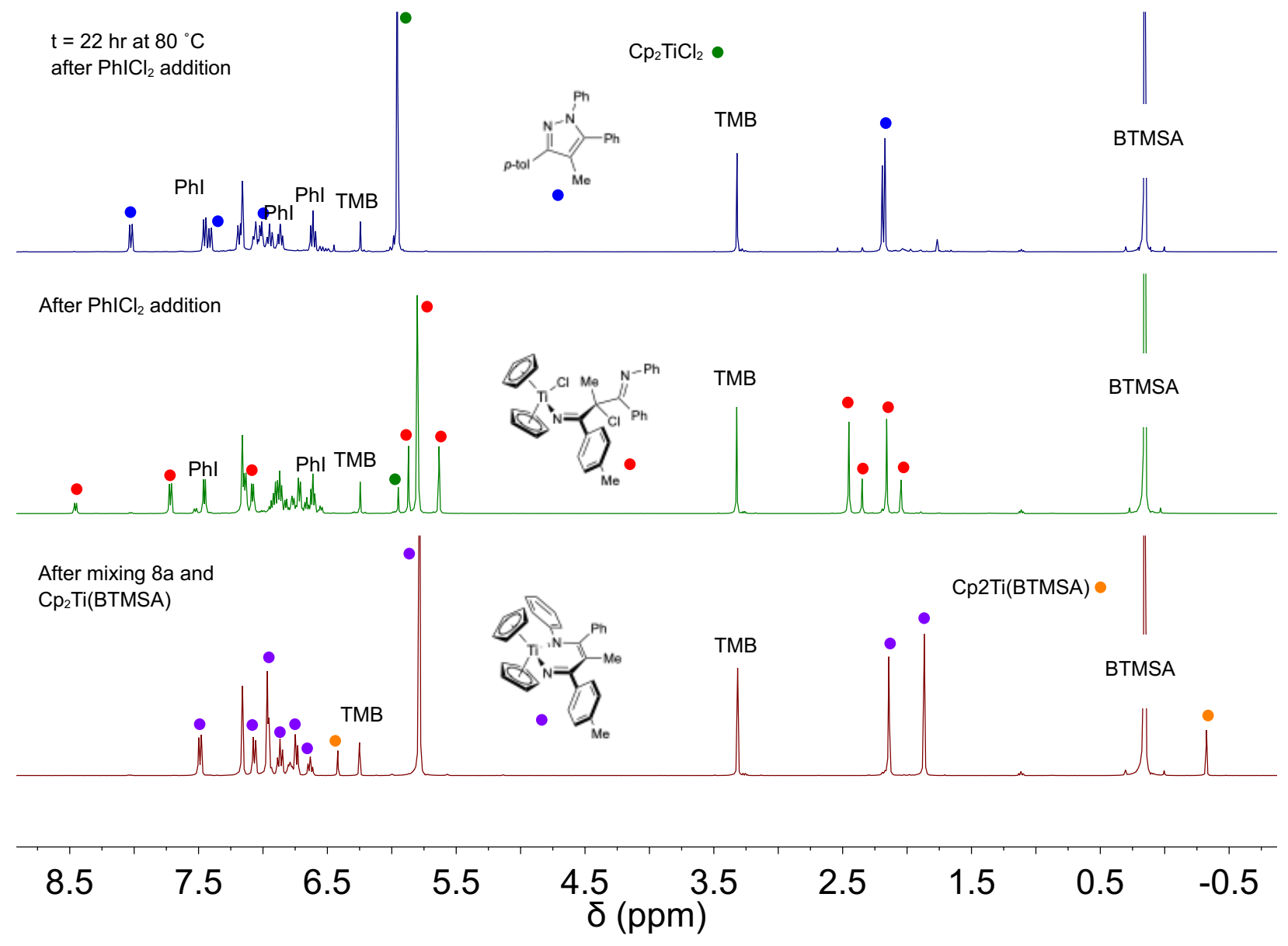

Figure S101. Stacked ${ }^{1} \mathrm{H}$ NMR spectra characterizing the one-pot conversion of $8 \mathrm{a}$ to $1 \mathrm{a}$ via titanocene intermediates $9 \mathrm{a}$ and $\mathbf{1 0 a}$. Bottom (red trace): Conversion of $\mathbf{8 a}$ to $9 \mathrm{a}$ through the reaction of $\mathbf{8 a}$ and $\mathrm{Cp}_{2} \mathrm{Ti}\left(\mathrm{BTMSA}\right.$ ). Middle (green trace): Conversion of $9 \mathbf{a}$ to $10 \mathrm{a}$ through the addition of $\mathrm{PhICl}_{2}$. Top (blue trace): Thermal conversion of $10 \mathrm{a}$ to pyrazole $1 \mathrm{a}$ and $\mathrm{Cp}_{2} \mathrm{TiCl}_{2}$. 


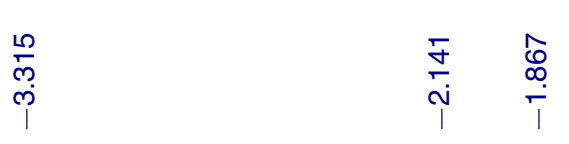

After mixing $8 a$ and $\mathrm{Cp}_{2} \mathrm{Ti}(\mathrm{BTMSA})$

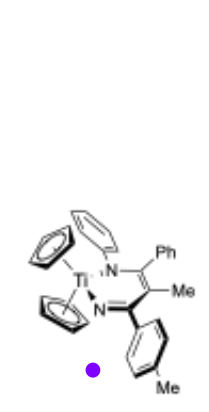

$$
\text { Cp2Ti(BTMSA) • }
$$

Cp2T(BTMSA)

BTMSA

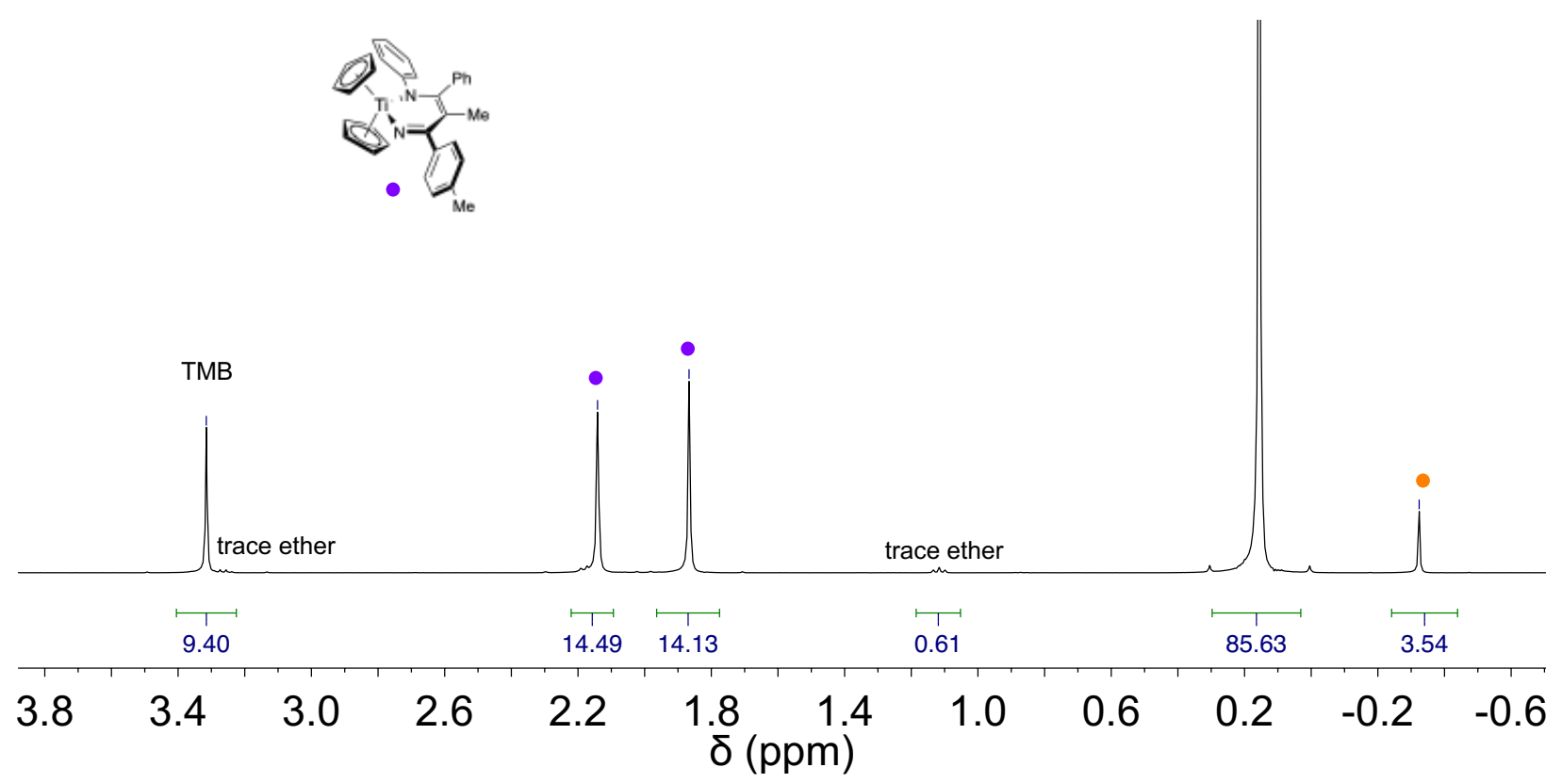

Figure S102. ${ }^{1} \mathrm{H}$ NMR spectrum characterizing the conversion of $8 \mathrm{a}$ to $9 \mathrm{a}$ through the reaction of $8 \mathrm{a}$ and $\mathrm{Cp}_{2} \mathrm{Ti}(\mathrm{BTMSA})$. 


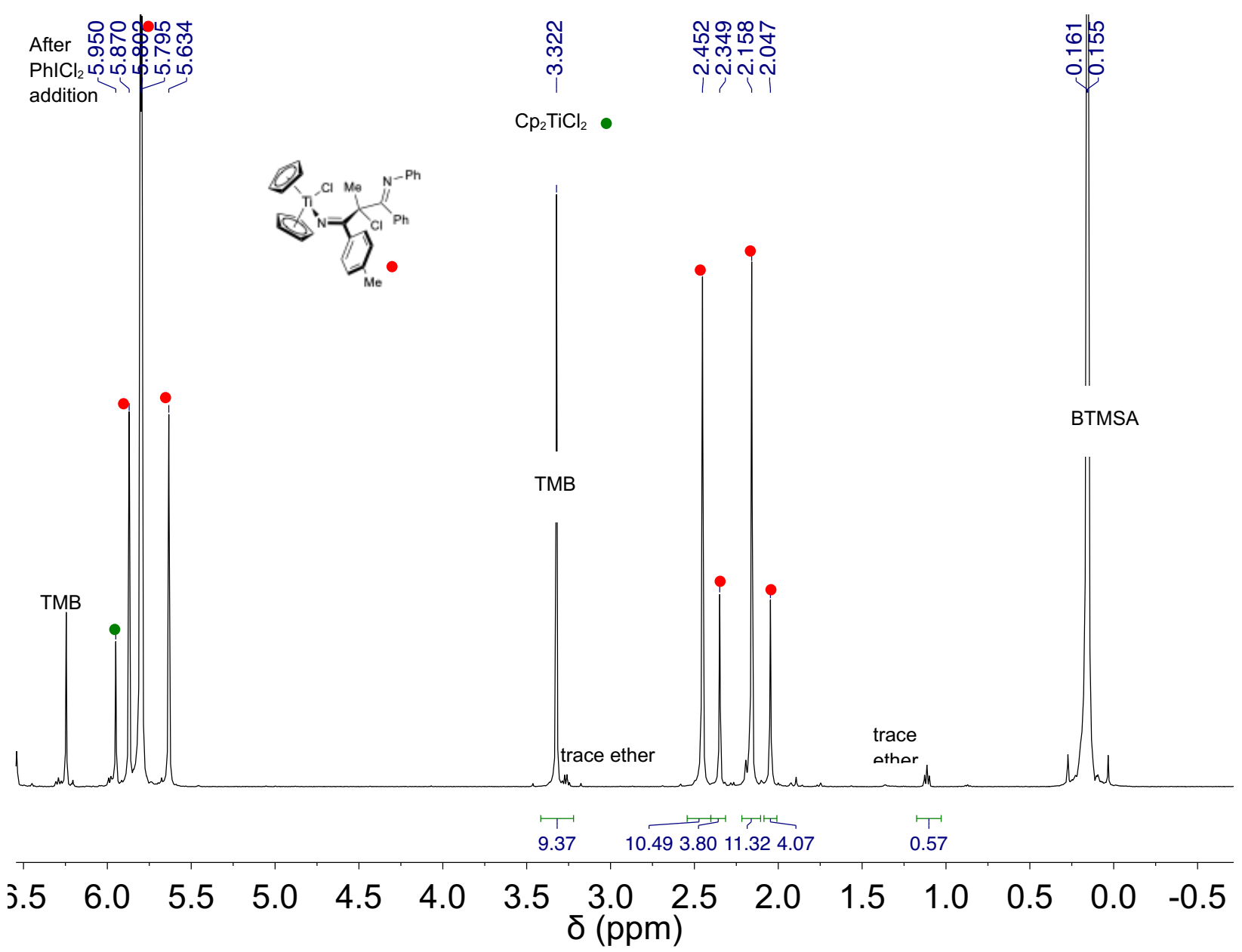

Figure S103. ${ }^{1} \mathrm{H}$ NMR spectrum characterizing the conversion of $9 \mathrm{a}$ to $10 \mathrm{a}$ through the addition of $\mathrm{PhICl}_{2}$. 


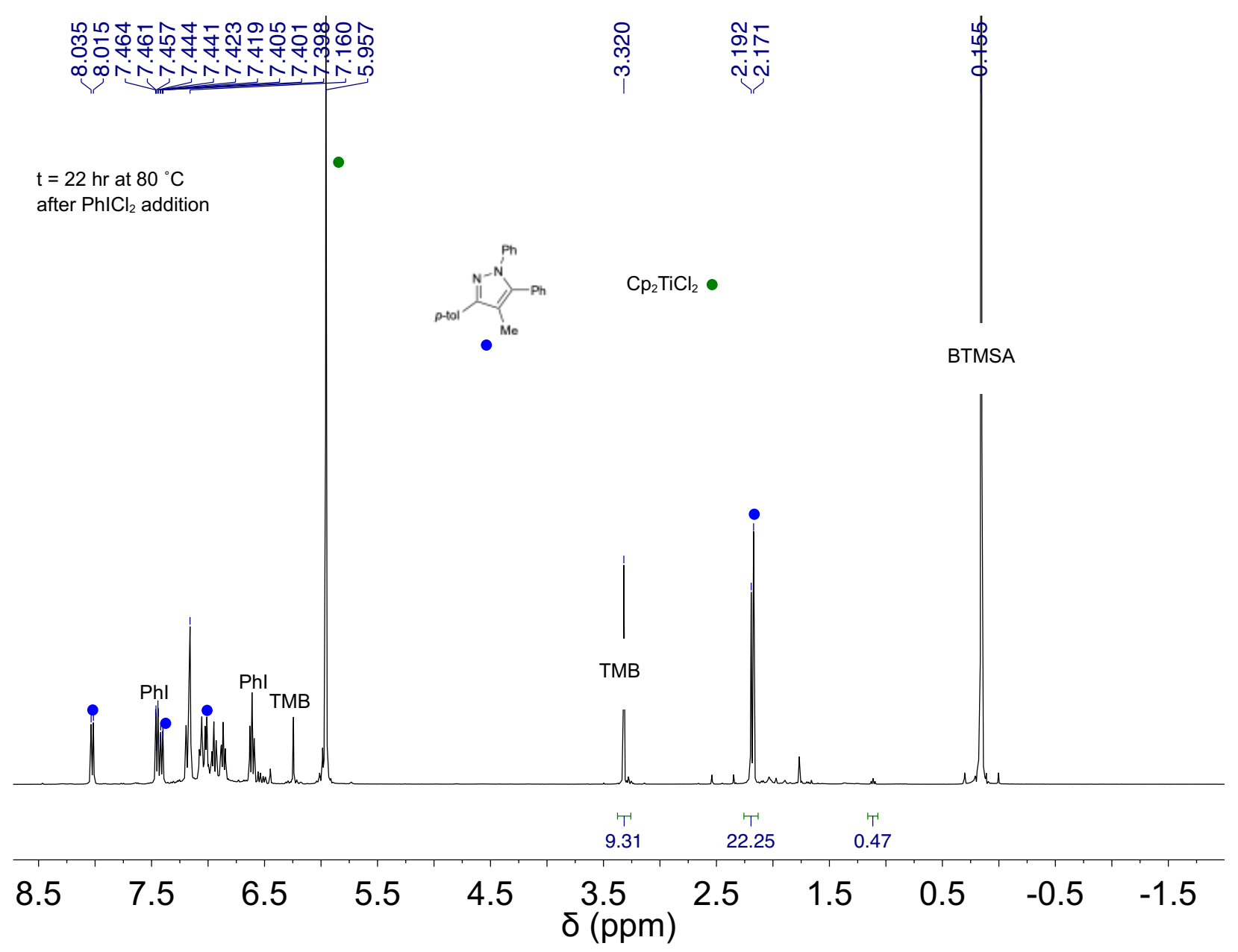

Figure S104. ${ }^{1} \mathrm{H}$ NMR spectrum characterizing the thermal conversion of $10 \mathrm{a}$ to pyrazole $1 \mathrm{a}$ and $\mathrm{Cp}_{2} \mathrm{TiCl}_{2}$ after $22 \mathrm{~h}$.

\section{Electrochemistry Data}

Cyclic voltammetry measurements were carried out at room temperature in a nitrogen-filled glovebox in a one compartment cell using a Pine WaveNow potentiostat with screen printed Pt working and auxiliary electrodes and a Ag pseudoreference electrode on a ceramic substrate. All potentials are reported relative to an internal ferrocene reference. DCM solutions of the electrolyte $(0.1 \mathrm{M}$

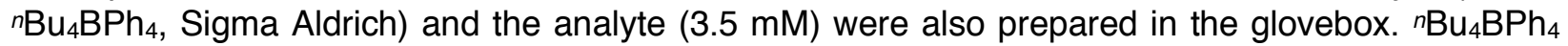
was vacuum-dried at $50{ }^{\circ} \mathrm{C}$ for several hours and recrystalized from DCM/hexanes at $-35{ }^{\circ} \mathrm{C}$ before use. 


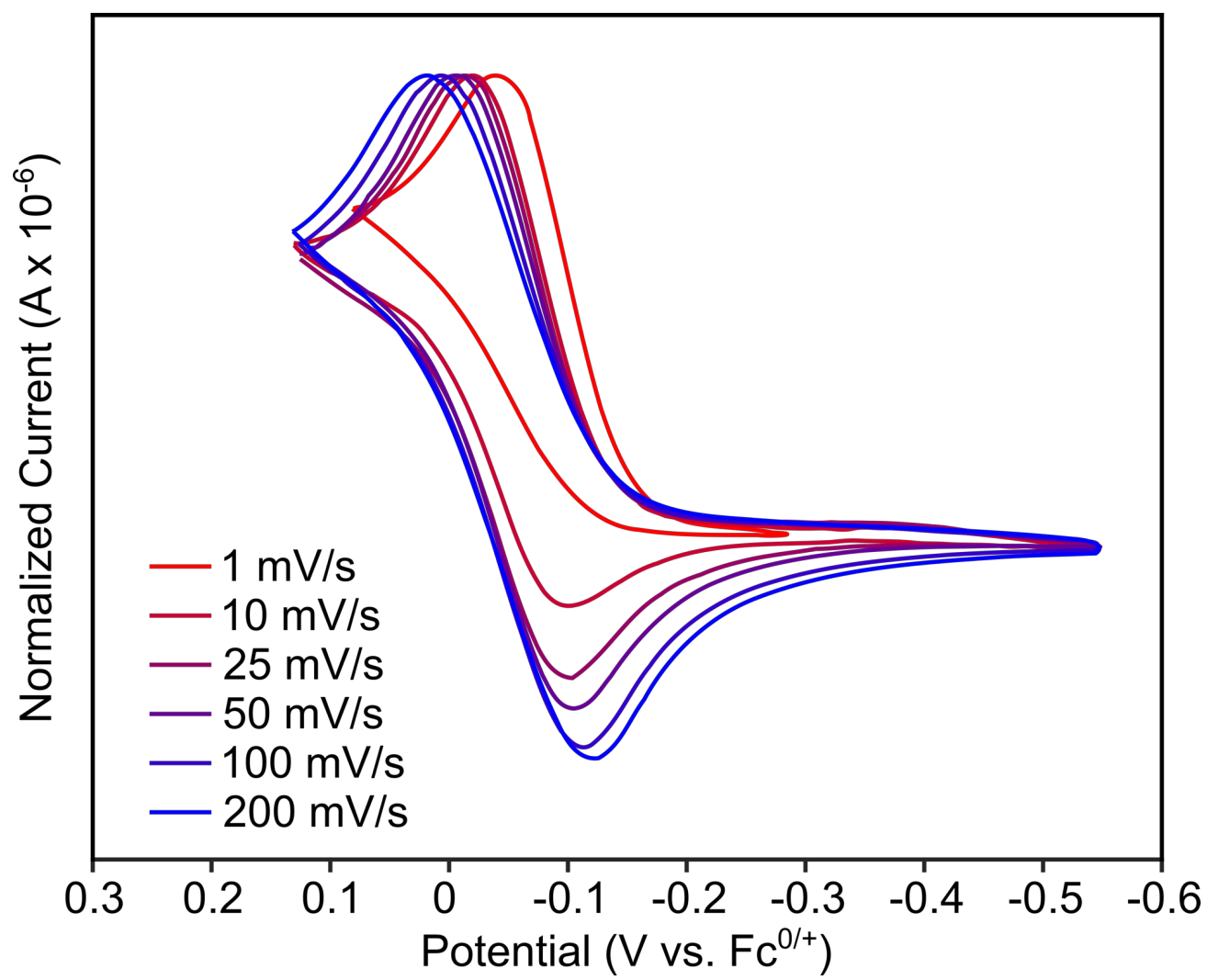

Figure S105. Cyclic voltammogram of $9 \mathrm{a}\left(\mathrm{V}\right.$ vs. $\left.\mathrm{Fc}^{0 /+}\right)$ with normalized current.

\section{XRD Data}

\begin{tabular}{|c|c|c|c|}
\hline & $6 a$ & $7 \mathbf{a}$ & $7 b$ \\
\hline CCDC Number & 1960336 & 1960334 & 1960337 \\
\hline Empirical Formula & $\begin{array}{l}\mathrm{C}_{46} \mathrm{H}_{40} \mathrm{Cl}_{4} \mathrm{~N}_{4} \mathrm{Ti}_{2} \\
\left(\mathrm{C}_{6} \mathrm{H}_{6}\right)\end{array}$ & $\mathrm{C}_{33} \mathrm{H}_{30} \mathrm{Cl}_{2} \mathrm{~N}_{4} \mathrm{Ti}$ & $\mathrm{C}_{29} \mathrm{H}_{30} \mathrm{Cl}_{2} \mathrm{~N}_{4} \mathrm{Ti}$ \\
\hline Formula Weight & 964.47 & 601.41 & 553.35 \\
\hline Temperature (K) & $100(2)$ & $100(2)$ & $100(2)$ \\
\hline$a, \AA$ & $9.2324(8)$ & $9.2825(4)$ & $10.952(4)$ \\
\hline$b, \AA$ & $9.9661(8)$ & $11.7953(5)$ & $16.038(5)$ \\
\hline$c, \AA$ & $13.0708(11)$ & $14.3737(5)$ & $15.834(6)$ \\
\hline$\alpha,{ }^{\circ}$ & $100.435(3)$ & $86.209(1)$ & 90 \\
\hline$\beta, \circ$ & $100.308(4)$ & $82.030(1)$ & $105.03(2)$ \\
\hline$\gamma, \circ$ & $93.958(4)$ & $70.430(1)$ & 90 \\
\hline Volume, $\AA^{3}$ & $1157.27(17)$ & $1468.21(10)$ & $2686.1(17)$ \\
\hline $\mathrm{Z}$ & 1 & 2 & 4 \\
\hline Crystal System & Triclinic & Triclinic & Monoclinic \\
\hline Space Group & $\mathrm{P} \overline{1}$ & $\mathrm{P} \overline{1}$ & $\mathrm{P} 2{ }_{1} / \mathrm{c}$ \\
\hline
\end{tabular}




\begin{tabular}{|c|c|c|c|}
\hline $\mathrm{d}_{\mathrm{calc}}, \mathrm{g} / \mathrm{cm}^{3}$ & 1.384 & 1.360 & 1.368 \\
\hline$\theta$ Range, ${ }^{\circ}$ & 2.878 to 30.506 & 2.345 to 29.448 & 2.308 to 30.543 \\
\hline$\mu, \mathrm{mm}^{-1}$ & 0.617 & 0.503 & 0.543 \\
\hline Abs. Correction & Multi-scan & Multi-scan & Multi-scan \\
\hline GooF & 1.075 & 1.058 & 1.093 \\
\hline$R_{1}^{a}$ & 0.0570 & 0.0373 & 0.0513 \\
\hline $\mathrm{wR}_{2}{ }^{b}[\mathrm{I}>2 \sigma(\mathrm{I})]$ & 0.1679 & 0.0948 & 0.1391 \\
\hline \multicolumn{4}{|c|}{${ }^{a} \mathrm{R}_{1}=\sum|| \mathrm{F}_{\mathrm{o}}|-| \mathrm{F}_{\mathrm{c}}|| / \sum\left|\mathrm{F}_{\mathrm{o}}\right| \cdot{ }^{b} \mathrm{wR}_{2}=\left[\sum\left[\mathrm{w}\left(\mathrm{F}_{\mathrm{o}}^{2}-\mathrm{F}_{\mathrm{c}}{ }^{2}\right)^{2}\right] / \sum\left[\mathrm{w}\left(\mathrm{F}_{\mathrm{o}}{ }^{2}\right)^{2}\right]^{1 / 2}\right.$} \\
\hline & $5 \mathbf{a}$ & $9 a$ & $10 \mathbf{a}$ \\
\hline CCDC Number & 1960338 & 1960339 & 1960333 \\
\hline Empirical Formula & $\mathrm{C}_{25} \mathrm{H}_{27} \mathrm{Cl}_{2} \mathrm{~N}_{3} \mathrm{Ti}$ & $\mathrm{C}_{33} \mathrm{H}_{30} \mathrm{~N}_{2} \mathrm{Ti}$ & $\begin{array}{l}2\left(\mathrm{C}_{33} \mathrm{H}_{30} \mathrm{Cl}_{2} \mathrm{~N}_{2} \mathrm{Ti}\right) \\
\left(\mathrm{Et}_{2} \mathrm{O}\right)\end{array}$ \\
\hline Formula Weight & 488.29 & 502.49 & 1220.84 \\
\hline Temperature (K) & $100(2)$ & $100(2)$ & $125(2)$ \\
\hline$a, \AA$ & $17.105(1)$ & $8.5180(1)$ & $19.9721(6)$ \\
\hline$b, \AA$ & $9.7060(5)$ & $11.7992(3)$ & $20.5620(6)$ \\
\hline$c, \AA$ & $150.0812(8)$ & $25.2433(5)$ & $15.0039(4)$ \\
\hline$\alpha, \circ$ & 90 & 90 & 90 \\
\hline$\beta, \circ$ & $106.174(2)$ & $92.432(1)$ & $97.505(1)$ \\
\hline$\gamma, \circ$ & 90 & 90 & 90 \\
\hline Volume, $\AA^{3}$ & $2404.7(2)$ & $2534.82(9)$ & $6108.8(3)$ \\
\hline $\mathrm{Z}$ & 4 & 4 & 4 \\
\hline Crystal System & Monoclinic & Monoclinic & Monoclinic \\
\hline Space Group & $\mathrm{P} 2{ }_{1} / \mathrm{c}$ & $\mathrm{P} 2{ }_{1} / \mathrm{c}$ & $\mathrm{P} 2{ }_{1} / \mathrm{c}$ \\
\hline $\mathrm{d}_{\text {calc }}, \mathrm{g} / \mathrm{cm}^{3}$ & 1.349 & 1.317 & 1.327 \\
\hline$\theta$ Range, ${ }^{\circ}$ & 2.435 to 32.125 & 2.940 to 32.408 & 2.548 to 28.750 \\
\hline$\mu, \mathrm{mm}^{-1}$ & 0.595 & 0.363 & 0.484 \\
\hline Abs. Correction & Multi-scan & Multi-scan & Multi-scan \\
\hline GooF & 1.057 & 1.019 & 1.020 \\
\hline$R_{1}^{a}$ & 0.0407 & 0.0512 & 0.0636 \\
\hline $\mathrm{wR}_{2}^{b}[\mathrm{I}>2 \sigma(\mathrm{I})]$ & 0.1118 & 0.1233 & 0.1516 \\
\hline \multicolumn{4}{|c|}{${ }^{a} \mathrm{R}_{1}=\sum|| \mathrm{F}_{\mathrm{o}}|-| \mathrm{F}_{\mathrm{c}} \| / \sum\left|\mathrm{F}_{\mathrm{o}}\right| \cdot{ }^{b} \mathrm{wR}_{2}=\left[\sum\left[\mathrm{w}\left(\mathrm{F}_{\mathrm{o}}^{2}-\mathrm{F}_{\mathrm{c}}{ }^{2}\right)^{2}\right] / \sum\left[\mathrm{w}\left(\mathrm{F}_{\mathrm{o}}{ }^{2}\right)^{2}\right]^{1 / 2}\right.$} \\
\hline & & S1 & \\
\hline & CCDC Number & 1960335 & \\
\hline & Empirical Formula & $\mathrm{C}_{40} \mathrm{H}_{46} \mathrm{Cl}_{2} \mathrm{~N}_{4} \mathrm{Ti}$ & \\
\hline & Formula Weight & 701.58 & \\
\hline & Temperature (K) & $100(2)$ & \\
\hline & $a, \AA$ & $15.6951(6)$ & \\
\hline & $b, \AA$ & $12.0965(5)$ & \\
\hline & $c, \AA$ & $20.2737(9)$ & \\
\hline & $\alpha,{ }^{\circ}$ & 90 & \\
\hline & $\beta, \circ$ & $109.224(1)$ & \\
\hline & $\gamma, \circ$ & 90 & \\
\hline & Volume, $\AA^{3}$ & $3634.5(3)$ & \\
\hline & Z & 4 & \\
\hline
\end{tabular}




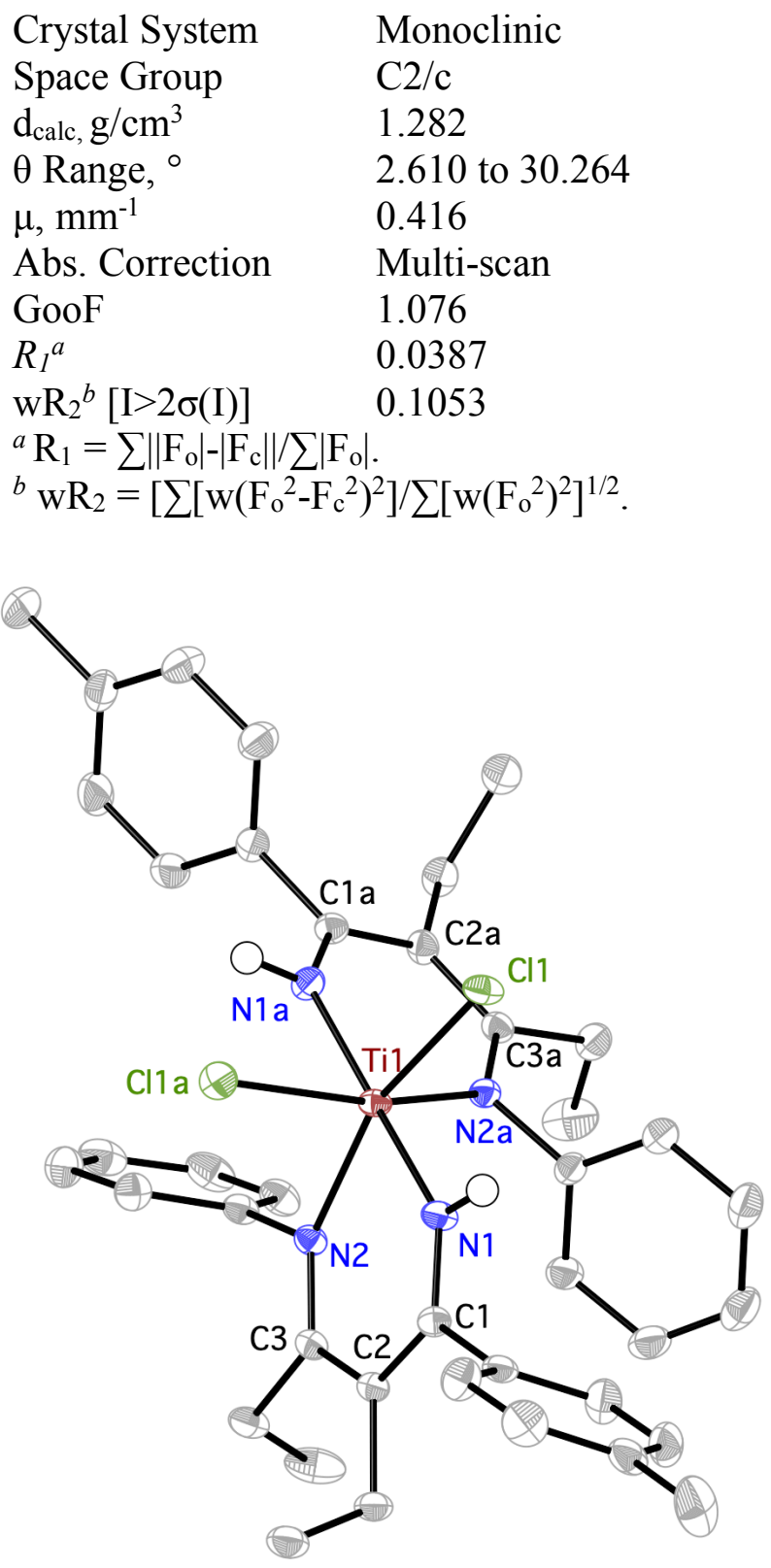

Figure S106. ORTEP diagram of ( $\mathrm{HADA})_{2} \mathrm{TiCl}_{2}(\mathrm{~S} 1)$. Thermal ellipsoids are drawn at $50 \%$ probability. 


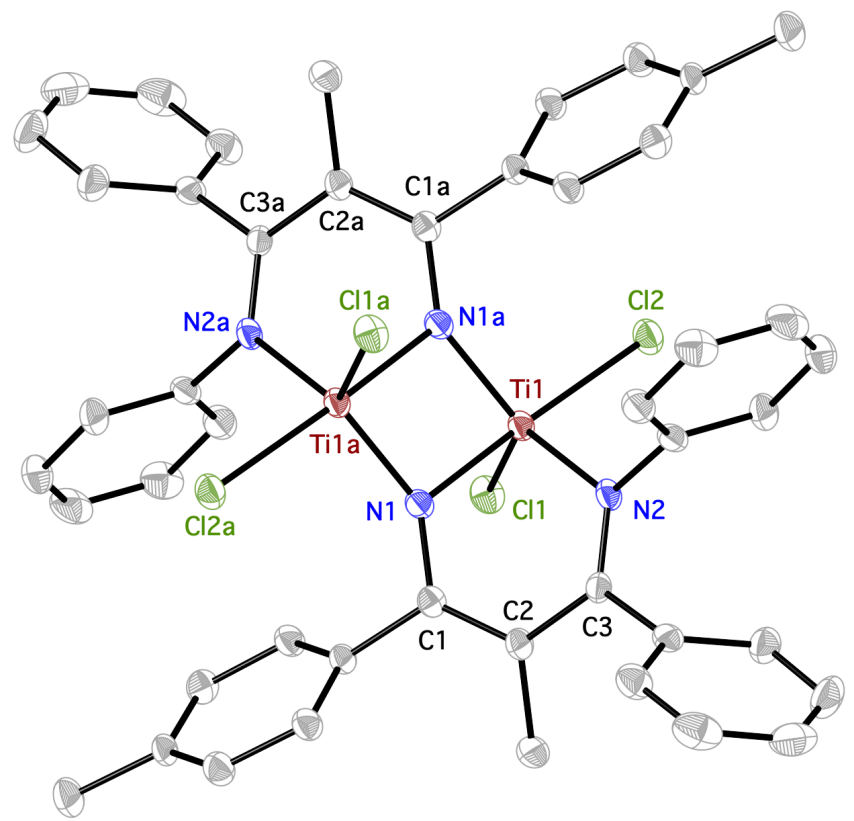

Figure S107. ORTEP diagram of $\left[\mathrm{TiCl}_{2}\left(\mathrm{ADA}^{\mathrm{Ph}}\right)\right]_{2}(6 \mathbf{6})$. Thermal ellipsoids are drawn at $50 \%$ probability.

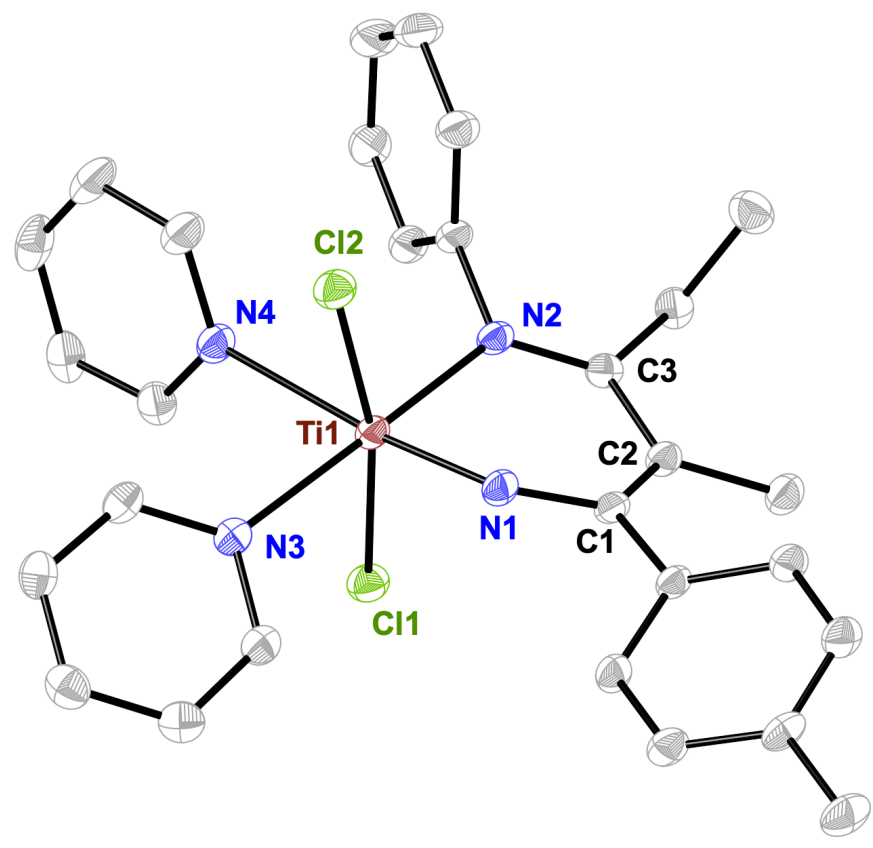

Figure S108. ORTEP diagram of $\mathrm{py}_{2} \mathrm{TiCl}_{2}\left(\mathrm{ADA}^{\mathrm{Et}}\right)$ (7b). Thermal ellipsoids are drawn at $50 \%$ probability.

Computational Methods 
The computational methods were adapted from previous work on a similar system. ${ }^{\text {REF }}$ All calculations were performed with Gaussian 16 version a.03. Structures were optimized using the M06 functional, $6-311 \mathrm{G}(\mathrm{d}, \mathrm{p})$ basis set, and the "ultrafine" grid. All structures were optimized in Bromobenzene using the SMD continuum solvation model to best approximate the experimental conditions. Frequency calculations were performed on the optimized geometries at the same level of theory (M06/6$311 \mathrm{G}(\mathrm{d}, \mathrm{p}) / \mathrm{SMD}$ ) to confirm the structure as a local minimum (0 imaginary frequencies) or a transition state (1 imaginary frequency). Thermal corrections were done at $418.15 \mathrm{~K}$ and $1 \mathrm{~atm}$. All frequencies below $50 \mathrm{~cm}^{-1}$ were scaled to $50 \mathrm{~cm}^{-1}$ for the thermal energy calculation.
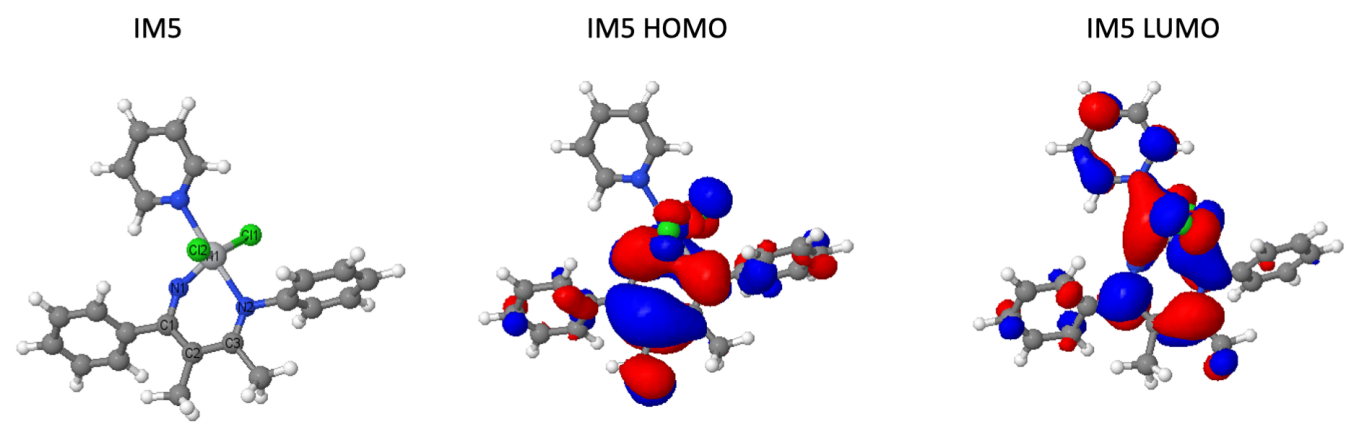

Figure S109. Computed structure of IM5, with HOMO and LUMO surfaces shown.

Structure: $\mathrm{py}_{3} \mathrm{TiCl}_{2}(\mathrm{NPh})$

Free Energy: -2800.554950

Free Energy Corrected: -2800.551889

48

Ti $-0.0914580 .093667-0.857696$

$\mathrm{N}-0.4352971 .8020720 .619507$

N - $2.425908-0.377652-0.445936$

N $0.039865-1.3459410 .908280$

N $1.5975070 .247853-0.825927$

Cl $-0.206030-1.775203-2.335169$

$\mathrm{Cl}-0.7840751 .685936-2.489031$

C $2.9452700 .081556-0.694228$

C $3.8273591 .172846-0.787681$

C $5.1924250 .990775-0.639203$

C $3.487455-1.194227-0.450137$

C $4.854039-1.362668-0.305183$

C $5.715626-0.274347-0.395711$

H $3.4134692 .156895-0.992633$

H $5.8581991 .845924-0.719609$

H $5.254083-2.356566-0.122912$

H $6.786607-0.412434-0.283217$

H $2.809150-2.042287-0.389849$

C $0.752423-1.0179941 .994747$ 
C - $0.471916-2.5845190 .852282$

C $0.966084-1.8864553 .049005$

C - $0.297076-3.5169531 .858269$

C $0.433462-3.1636852 .980855$

H $1.178998-0.0208272 .019109$

H $1.551083-1.5604273 .901177$

H $0.589494-3.8731773 .787028$

H - $0.730270-4.5047171 .751428$

H -1.034195 - 2.833151 -0.041716

C -3.235932 -0.494743 -1.504859

C - $4.588616-0.768760-1.393002$

C -5.135007 -0.932320 -0.131025

C -4.305096 -0.814067 0.973809

C - $2.965718-0.5383710 .769249$

H -2.775991 -0.360606 -2.479373

H -5.194912 -0.850647-2.287795

H -6.191675 -1.148250 -0.008630

H -2.292825 -0.433631 1.617437

H -4.684363 -0.932055 1.982534

C 0.6316862 .3490071 .221258

C - 1.6149922 .4218440 .769997

C - 1.7761293 .5632391 .532144

C -0.6704604 .1066082 .166650$

C 0.5573013 .4874282 .002790

H 1.5831441 .8557791 .049969

H 1.4568163 .8802242 .462421

H -0.7626585 .0045452 .768995$

H -2.7564584.018192 1.613279

H -2.4601381.994571 0.241436

Structure: IM3

Free Energy: -2460.173636

Free Energy Corrected: -2460.171965

36

Ti 0.4609940 .4108050 .088406

N -1.429070 0.3376280 .267922

$\mathrm{Cl} 0.385224-0.304266-2.178790$

$\mathrm{Cl} 0.9702500 .2821002 .395829$

C - $2.588995-0.4274420 .144558$

C -3.488184 -0.246466 -0.908456

C - $4.599990-1.067783-1.016060$

C - $2.804556-1.4536211 .065698$

C -3.915964 -2.271920 0.946277

C -4.820903 -2.079761-0.090659 
H -3.295431 $0.520902-1.652552$

H -5.292889 -0.922933 -1.839563

H -4.077870 -3.064843 1.670276

H -5.690930 - $2.722327-0.182304$

H - $2.091950-1.5884381 .874748$

C - $0.0158022 .232266-0.063907$

C - 1.3070651 .7030330 .082843

N 2.495639 -0.466288 -0.072102

C $3.5137620 .372852-0.278819$

C $2.735714-1.7750700 .038931$

C $4.819540-0.067791-0.384114$

H $3.2652521 .429884-0.358904$

C $4.012088-2.295222-0.052310$

H $1.871398-2.4138470 .205698$

C $5.071434-1.425951-0.267955$

H $5.6185220 .644553-0.552085$

H $4.168093-3.3631320 .044505$

H $6.085354-1.804774-0.344295$

C - 2.5101782 .5909420 .095491

$\mathrm{H}-2.2935233 .4949000 .671008$

H - $-7.7569292 .904511-0.925291$

H -3.379524 2.090177 0.525415

C $0.2644663 .680547-0.211171$

H - $0.2988794 .126167-1.041926$

H 0.0001774 .2355960 .699447

H $1.3260193 .861645-0.401570$

Structure: IM4

Free Energy: -2784.444114

Free Energy Corrected: -2784.438344

49

Ti $0.400895-0.1289040 .199765$

N $2.071445-1.0406900 .321234$

Cl $0.5094960 .040435-2.177693$

$\mathrm{Cl} 0.0922570 .3729142 .519844$

C $3.422358-1.002671-0.008484$

C $3.975169-1.787884-1.024198$

C $5.320338-1.669593-1.339335$

C $4.237281-0.0852110 .662529$

C 5.5788400 .0292820 .336450

C $6.128994-0.765725-0.662008$

H $3.337854-2.468977-1.580422$

H $5.737684-2.282969-2.132682$

H 6.2015720 .7409840 .870664 


$$
\begin{aligned}
& \text { H } 7.180802-0.676751-0.915301 \\
& \text { H } 3.7962980 .5191431 .451903 \\
& \text { C - } 0.082234-1.9955700 .389512 \\
& \text { C } 1.280191-2.1977280 .417507 \\
& \text { N } 0.3259272 .1531410 .068612 \\
& \text { C - } 0.6965122 .9862960 .272478 \\
& \text { C } 1.5352372 .671122-0.169973 \\
& \text { C - } 0.5518764 .3612630 .230603 \\
& \text { H - } 1.6591262 .5302630 .481389 \\
& \text { C } 1.7695044 .032495-0.218506 \\
& \text { H } 2.3451451 .960498-0.332565 \\
& \text { C } 0.7027344 .894712-0.018872 \\
& \text { H - } 1.4133774 .9977680 .396625 \\
& \text { H } 2.7697584 .401190-0.413339 \\
& \text { H } 0.8485965 .969431-0.055408 \\
& \text { C - } 2.967498-0.062616-0.147625 \\
& \mathrm{~N}-1.8362540 .130341-0.051256 \\
& \text { C - } 4.359739-0.323815-0.248119 \\
& \text { C - } 5.045473-0.7954640 .874878 \\
& \text { C - } 5.022095-0.118283-1.461059 \\
& \text { C - } 6.400051-1.0584720 .776458 \\
& \text { H - } 4.510435-0.9485501 .806665 \\
& \text { C }-6.376834-0.386936-1.542432 \\
& \text { H - } 4.4701570 .244692-2.321541 \\
& \text { C - } 7.062838-0.854455-0.427889 \\
& \text { H -6.941549-1.424354 } 1.642270 \\
& \text { H - } 6.900649-0.231837-2.479578 \\
& \mathrm{H}-8.125714-1.063065-0.498801 \\
& \text { C - }-1.161901-2.9791080 .595592 \\
& \text { H - } 1.828771-3.012616-0.275973 \\
& \text { H }-0.804467-4.0017350 .772663 \\
& \text { H - } 1.786362-2.6895771 .453140 \\
& \text { C } 1.934678-3.5291660 .629901 \\
& \text { H } 2.102528-4.040235-0.324230 \\
& \text { H } 2.900810-3.4192621 .129554 \\
& \text { H } 1.292600 \text {-4.169462 } 1.238995
\end{aligned}
$$

Structure: TS2

Free Energy: -2784.404174

Free Energy Corrected: -2784.400899

49

Ti $-0.301218-0.5658570 .408341$

$\mathrm{N}-0.7028401 .4809100 .713034$

Cl -0.278387 $0.044772-1.894967$ 
$\mathrm{Cl}-1.285283-1.1821832 .498683$

C - 1.4707242 .5078750 .151501

C - $0.9455433 .462117-0.722265$

C - $1.7720934 .432808-1.265939$

C - 2.8359642 .5223530 .441931

C -3.655365 $3.498386-0.101858$

C -3.125726 4.459393 -0.954071

H $0.1047963 .418805-0.997076$

H -1.357363 5.167473 -1.949623

H -4.714016 3.5079390 .139023

H -3.768601 $5.220930-1.384397$

H -3.2325361.764495 1.113328

C 1.1330330 .3130981 .419412

C 0.5296891 .5917241 .185334

$\mathrm{N}-1.677709-2.230953-0.272002$

C - $1.436246-3.542767-0.244685$

C - $2.883724-1.805643-0.663453$

C $-2.389829-4.475533-0.613274$

H $-0.443893-3.8386110 .080204$

C -3.891450 -2.669788-1.044586

H -3.044069 -0.728613 -0.673527

C -3.637752 -4.033106-1.020470

H - $2.149356-5.531817-0.577660$

H -4.851974 - 2.275853 -1.355303

H -4.405483 -4.741044 -1.315550

C $1.888020-1.1497690 .028192$

N $1.143619-2.0841920 .103500$

C $3.185210-0.653742-0.377510$

C $4.268680-1.527412-0.273126$

C $3.3594590 .634814-0.875879$

C $5.528171-1.101067-0.661213$

H $4.110986-2.5289600 .115883$

C $4.6190701 .045397-1.277070$

H $2.5018461 .297359-0.955855$

C $5.7030700 .181889-1.163128$

H $6.375562-1.773118-0.572517$

H $4.7588322 .043914-1.678136$

H $6.6909770 .512527-1.468473$

C 2.2178650 .1389832 .418487

H 3.1317540 .7061132 .186228

H 1.8628600 .4836283 .400259

H $2.499066-0.9133332 .535240$

C 1.2096082 .8766431 .521208

H 2.0470453 .0633690 .837980 
H 0.5308323 .7305121 .489457

H 1.6356922 .7988302 .526913

Structure: IM5

Free Energy: -2784.490882

Free Energy Corrected: -2784.489003

49

Ti 0.4612890 .6936790 .017606

N $1.424510-1.1754260 .128439$

Cl $1.5607941 .293104-1.950284$

C $2.841832-1.0854540 .000596$

C $3.593967-0.4888161 .007356$

C $4.962665-0.3161580 .837769$

C $3.465563-1.508768-1.171987$

C $4.828918-1.333999-1.333664$

C $5.582440-0.733822-0.330231$

H $3.102872-0.1708771 .922870$

H 5.5453160 .1477641 .627954

H $5.307211-1.660453-2.252295$

H $6.650511-0.591743-0.462702$

H $2.861771-1.955683-1.957655$

$\mathrm{Cl} 0.4736850 .9208022 .342360$

C - $1.140205-3.8745770 .668329$

H $-0.717117-4.2466951 .607576$

H $-0.936607-4.636828-0.095467$

C - $0.582728-2.5256730 .310739$

C $0.840195-2.3508070 .308364$

C $1.665083-3.5802970 .533626$

H $1.493580-4.310667-0.265276$

H 2.731917 -3.371270 0.588253

H $1.364238-4.0637121 .468262$

H $-2.221080-3.8325210 .806113$

C - $-1.417763-1.470314-0.046841$

$\mathrm{N}-0.928740-0.259732-0.309421$

C - $2.897810-1.586956-0.145290$

C - $-3.680172-0.6848700 .576360$

C - $3.521325-2.523163-0.967988$

C $-5.063409-0.7360360 .497365$

H -3.189635 0.0483871 .212822

C - $4.905247-2.558960-1.061663$

H - $2.917746-3.215940-1.548266$

C -5.678506 -1.671703-0.324635

H -5.663644 -0.041739 1.077700

H -5.382206 -3.284522 -1.713632 
H -6.761580 -1.707804 -0.392691

N -0.454372 2.727854 -0.042739

C - $1.7371572 .892467-0.385307$

C 0.2766993 .8092300 .256645

C - $2.3335294 .139580-0.437013$

H -2.286450 $1.987151-0.627076$

C -0.243799 5.0874950 .228826

H 1.3147703 .6326450 .527980

C - $1.5750955 .255500-0.123949$

H -3.376195 4.225230 -0.719968

H 0.3866535 .9324600 .479595

H -2.014575 $6.247211-0.155131$

Structure: TS3

Free Energy: -2784.415222

Free Energy Corrected: -2784.413891

49

Ti $0.214259-0.7079030 .668516$

N $1.6889380 .251165-0.347917$

$\mathrm{Cl}-0.250180-0.8374932 .924422$

C $3.0624370 .527004-0.215219$

C 3.7226840 .0816450 .926998

C 5.0660370 .3709211 .096110

C $3.7368181 .284201-1.171256$

C $5.0837091 .558415-0.998160$

C 5.7502561 .1016510 .132098

H $3.173592-0.4898081 .670376$

H 5.5829030 .0217451 .984167

H $5.6132822 .142579-1.744272$

H 6.8041841 .3240580 .266691

H $3.2001871 .663015-2.035980$

Cl $1.483483-2.7284810 .440956$

C - $1.3464340 .035205-2.459356$

H -1.204758 - $0.985852-2.828393$

H - $1.2561180 .702481-3.324980$

C - $0.3416570 .373030-1.409585$

C $1.0001060 .015265-1.518061$

C $1.627451-0.634797-2.701396$

H $1.7153770 .060973-3.544396$

H $2.617734-1.030978-2.468341$

H $1.005984-1.471894-3.037781$

H - $2.3686310 .116085-2.080075$

C - $0.5701611 .180933-0.242917$

N 0.4928381 .1592160 .617611 
C - $-1.6315872 .186399-0.057026$

C - 1.9596322 .5888121 .242495

C - $2.3027902 .782600-1.128268$

C - 2.9285183 .5539611 .463110

H - 1.4429602 .1321022 .082666

C -3.281776 $3.739563-0.903672$

H - $2.0408832 .520620-2.148206$

C -3.599613 4.1281810.390635

H -3.166148 3.8545282 .479151

H -3.789708 4.195733 - 1.748297

H - 4.3645374 .8791630 .563115

$\mathrm{N}-1.596739-1.8254360 .082042$

C - $2.778289-1.3644050 .521218$

C - $1.593732-2.894651-0.725636$

C -3.981937-1.943598 0.171063

H - $2.748078-0.4962901 .173718$

C - $2.756857-3.522849-1.132442$

H - $0.620373-3.252157-1.047237$

C - $3.972855-3.040385-0.677736$

H - $4.906839-1.5330720 .558558$

H - $2.699141-4.380559-1.792458$

H -4.902134 -3.514247 -0.976955

Structure: IM6

Free Energy: -2784.430973

Free Energy Corrected: -2784.427525

49

Ti $-0.021694-0.787542-0.298844$

$\mathrm{N}-1.7629320 .2457360 .321111$

$\mathrm{Cl}-0.105120-1.417834-2.504433$

C -3.142719 0.335105 -0.066753

C - $3.823016-0.819224-0.418340$

C - $5.158543-0.726713-0.786537$

C - $3.7622181 .577098-0.082882$

C -5.093343 1.659829-0.459800

C - $5.7908610 .508672-0.808495$

H -3.300599 - $1.771960-0.405900$

H -5.702391 -1.623163 -1.066616

H -5.589110 2.625154-0.482943

H -6.832882 $0.577631-1.105208$

H -3.192256 2.462199 0.186279

$\mathrm{Cl}-0.713756-2.7986860 .832435$

C 0.8270000 .6857222 .922616

H $0.572049-0.1702953 .554921$ 
H 0.7404631 .5897193 .535889

C - 0.0568330 .7401871 .724638

C - -1.3191700 .2249261 .670593$

C - $2.176912-0.3631442 .716209$

H -3.039844 0.2865142 .908331

H - $2.556265-1.3454122 .417010$

H - $1.622727-0.4740713 .650601$

H 1.8768320 .5835342 .632075

C 0.3081551 .1954000 .395412

$\mathrm{N}-0.8077850 .958397-0.466375$

C $1.2821782 .214060-0.006483$

C $1.5261682 .429083-1.369901$

C 2.0041452 .9721620 .920582

C $2.4621693 .359863-1.785374$

H $0.9715511 .852948-2.106209$

C 2.9516093 .8954020 .498898

H 1.8161752 .8566981 .982849

C $3.1881824 .093736-0.853395$

H $2.6326713 .510008-2.847417$

H 3.4986024 .4739181 .237974

H $3.9275214 .817987-1.181025$

N $2.073900-1.520619-0.088937$

C $3.093876-0.6917300 .179043$

C 2.359985-2.811911-0.325508

C $4.409053-1.1142840 .235843$

H 2.8439850 .3506980 .346995

C $3.648162-3.308849-0.300561$

H $1.517419-3.462474-0.535995$

C $4.694192-2.447072-0.010173$

H $5.191062-0.3989760 .462273$

H $3.819307-4.359386-0.504396$

H $5.716760-2.8090060 .020652$

Structure: Benzonitrile

Free Energy: -324.277836

Free Energy Corrected: $-\mathbf{3 2 4 . 2 7 7 8 3 6}$

13

C $0.0000001 .205472-1.473530$

C $0.0000001 .212488-0.089275$

C - 0.0000000 .0000000 .603882

C $-0.000000-1.212488-0.089275$

C $-0.000000-1.205472-1.473530$

C $0.000000-0.000000-2.164152$

H $0.0000002 .144815-2.016739$ 


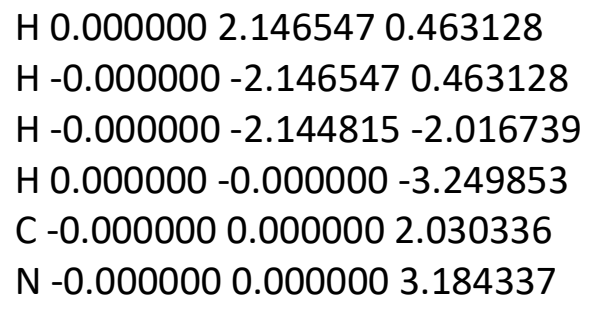

Structure: Pyridine

Free Energy: -248.112473

Free Energy Corrected: -248.112473

11

C $1.1375830 .718132-0.000205$

C $1.192442-0.668414-0.000121$

C $-0.000001-1.3758540 .000091$

C - $1.192442-0.6684140 .000210$

C - 1.1375830 .7181320 .000110

N $0.0000011 .410771-0.000094$

H -0.000001 -2.461701 0.000162

H $2.0581611 .299996-0.000369$

H $2.150442-1.177592-0.000220$

H - 2.150442 -1.177590 0.000377

H - 2.058161 1.2999980.000198

Structure: 2-Butyne

Free Energy: -155.855405

Free Energy Corrected: -155.854777

10

C $0.000004-0.0001260 .601461$

C $0.000004-0.000126-0.601461$

C 0.0000040 .0000532 .052303

C $0.0000040 .000053-2.052303$

H $0.027912-1.0195992 .450418$

H -0.8970970.4858312.450061

H 0.8691330 .5342082 .450132

$\mathrm{H}-0.8970970 .485831-2.450061$

H $0.027912-1.019599-2.450418$

H $0.8691330 .534208-2.450132$

\section{References}

(1) Whitesides, G. M.; Ehmann, W. J. Mechanism of Formation of 1,2,3,4Tetramethylnaphthalene from 2-Butyne and Triphenyltris(Tetrahydrofuran) Chromium(III). J. Am. Chem. Soc. 1970, 92 (19), 5625-5640. 
(2) Blake, A. J.; Collier, P. E.; Dunn, S. C.; Li, W.-S.; Mountford, P.; Shishkin, O. V. Synthesis and Imido-Group Exchange Reactions of Tert-Butylimidotitanium Complexes. J. Chem. Soc. Dalt. Trans. 1997, 0 (9), 1549-1558.

(3) Burlakov, V. V.; Polyakov, A. V.; Yanovsky, A. I.; Struchkov, Y. T.; Shur, V. B.; Vol'pin, M. E.; Rosenthal, U.; Görls, H. Novel Acetylene Complexes of Titanocene and Permethyltitanocene without Additional Ligands. Synthesis Spectral Characteristics and X-Ray Diffraction Study. J. Organomet. Chem. 1994, 476 (2), 197-206.

(4) Jones, N. A.; Liddle, S. T.; Wilson, C.; Arnold, P. L. Titanium(III) Alkoxy-NHeterocyclic Carbenes and a Safe, Low-Cost Route to $\mathrm{TiCl}_{3}(\mathrm{THF})_{3}$. Organometallics 2007, 26 (3), 755-757.

(5) He, R.; Jin, X.; Chen, H.; Huang, Z.-T.; Zheng, Q.-Y.; Wang, C. Mn-Catalyzed ThreeComponent Reactions of Imines/Nitriles, Grignard Reagents, and Tetrahydrofuran: An Expedient Access to 1,5-Amino/Keto Alcohols. J. Am. Chem. Soc. 2014, 136 (18), 65586561.

(6) Peerannawar, S.; Horton, W.; Kokel, A.; Török, F.; Török, M.; Török, B. Theoretical and Experimental Analysis of the Antioxidant Features of Diarylhydrazones. Struct. Chem. 2017, 28 (2), 391-402.

(7) Hayes, P. G.; Piers, W. E.; Parvez, M. Arene Complexes of $\beta$-Diketiminato Supported Organoscandium Cations: Mechanism of Arene Exchange and Alkyne Insertion in Solvent Separated Ion Pairs. Chem. - A Eur. J. 2007, 13 (9), 2632-2640. 